Historic, Archive Document

Do not assume content reflects current scientific knowledge, policies, or practices. 



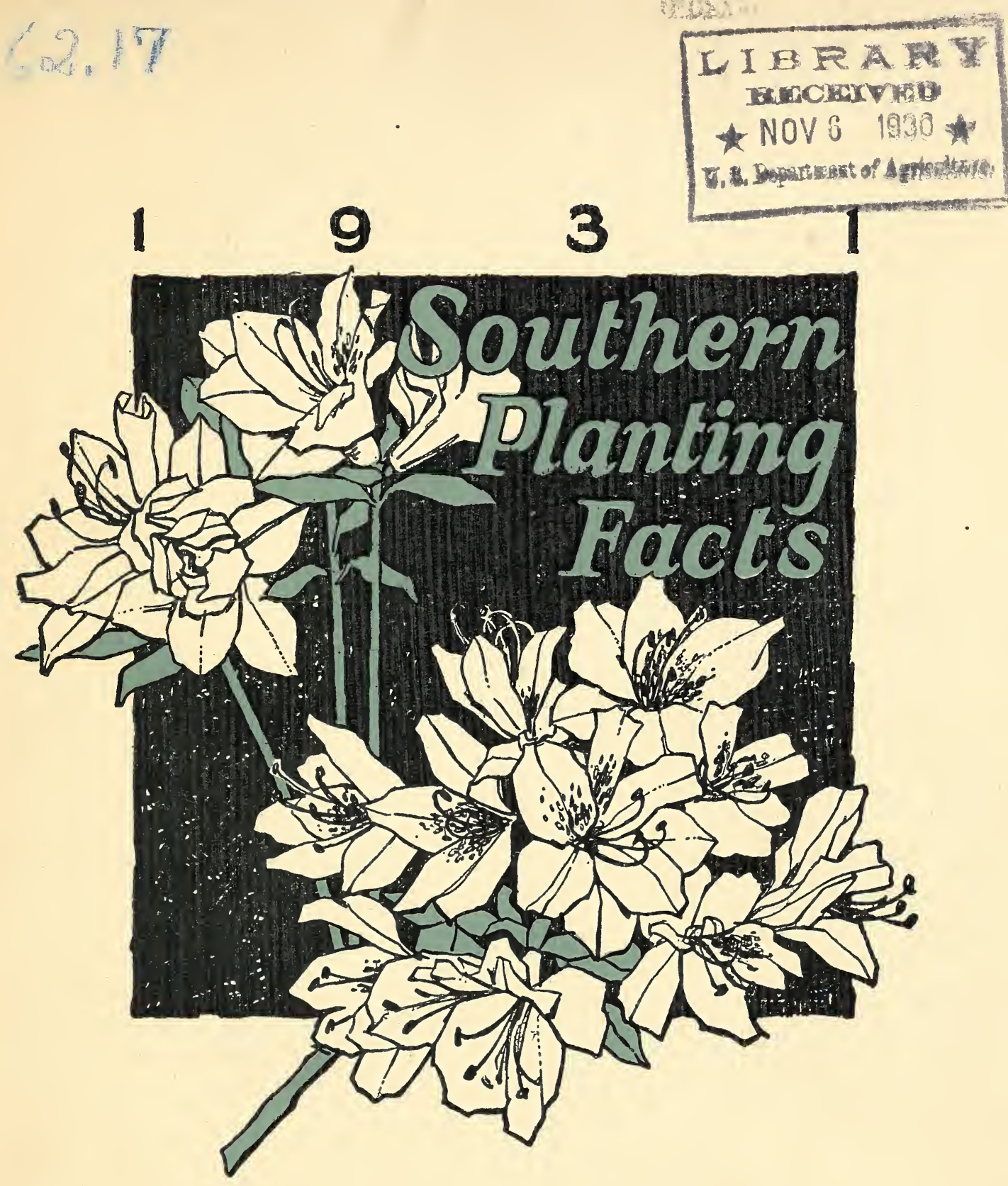

GLen Sarnt Mary NuRseries Co.

GLEN SAINT MARY, FLORIDA 


\section{Terms of Business}

Location.-General Office and Nurseries at Glen Saint Mary, Baker County, Florida, on the Seaboard Air Line Railway, and State Road No. 1, thirty miles west of Jacksonville. Office and Citrus Nurseries at Winter Haven, Polk County, Florida.

Long-Distance Telephone and Western Union Telegraph office in our main office.

Invitations to Visitors. - We take pleasure in showing our stock to persons wishing to purchase; if notified in time, we will meet visitors at the station on arrival.

No Agents.-We employ no agents, and have no connection with any other nursery. Trees sold to dealers must be resold by them upon their own responsibility. We are responsible only to parties purchasing direct from our nurseries.

Minimum Orders. - We do not care to ship orders amounting to less than $\$ 2$.

Applying Prices.-Five, fifty and frve hundred trees of one class, at ten, hundred and thousand rates, respectively, purchaser's selection from varieties of one fruit having a common price. For instance, fifty or more peaches, in one or more varieties, would come at the hundred rate, and frve hundred or more at the thousand rate. The foregoing does not apply to badly assorted orders, or to long lists made up of a few each of many varieties.

Terms Cash with order, if for immediate shipment. Orders for trees to be held for some weeks after the shipping season opens should also be accompanied by full payment. On orders booked in advance of the shipping season 25 per cent down, with the balance due when the shipping season opens. We do not care to ship C. O. D.

Remittances.-To secure safety and prompt acceptance, remittances should be made by Bank Draft, Express or Post Office Money Order, Registered Letter, or Prepaid Express.

Method of Shipment.-Shipping directions should be plainly written, and we urge our customers, in all cases, to use our order sheets. We shall be pleased to forward additional ones upon application. Kindly indicate whether shipment is to be made by freight, express or mail. When method of shipment is left to us, or when no directions are given, we will ship according to our best judgment, by such means as we believe to be in the best interests of our customers.

Transportation at Purchaser's Risk and Expense.-AII transportation charges are to be paid by the purchaser, and our responsibility ceases upon delivery to forwarding companies; claims for losses or damages must be made upon the latter. We will, however, start a tracer for delayed shipments, if notified, and use every means at our command to secure prompt delivery, or recovery in case of damage or loss.

Shipping by Parcel Post.-In ordering trees or plants for shipment by parcel post, add 25 per cent to the list price, to cover cost of packing and postage.

Time of Shipment.-Unless instructed otherwise, orders received during the shipping season will be forwarded as soon after their receipt as possible, and orders booked in advance will be shipped as soon as may be after the shipping season opens.

Shipping and Planting Season.-November to March for all trees and shrubs grown in the open field; balled plants, bamboos, grasses and pot-grown plants may be shipped at any time. Shipments March to November should go by express or post. Prices in this catalogue cover the shipping season of 1930-31, ending May 1, 1931.

Selecting Varieties suited to Iocality is of the first importance, and can often be more advantageously done by ourselves than by purchasers. We are always glad to aid our customers in their selections, when so desired, and will, upon request, cheerfully furnish additional information in regard to the adaptability or desirability of varieties.

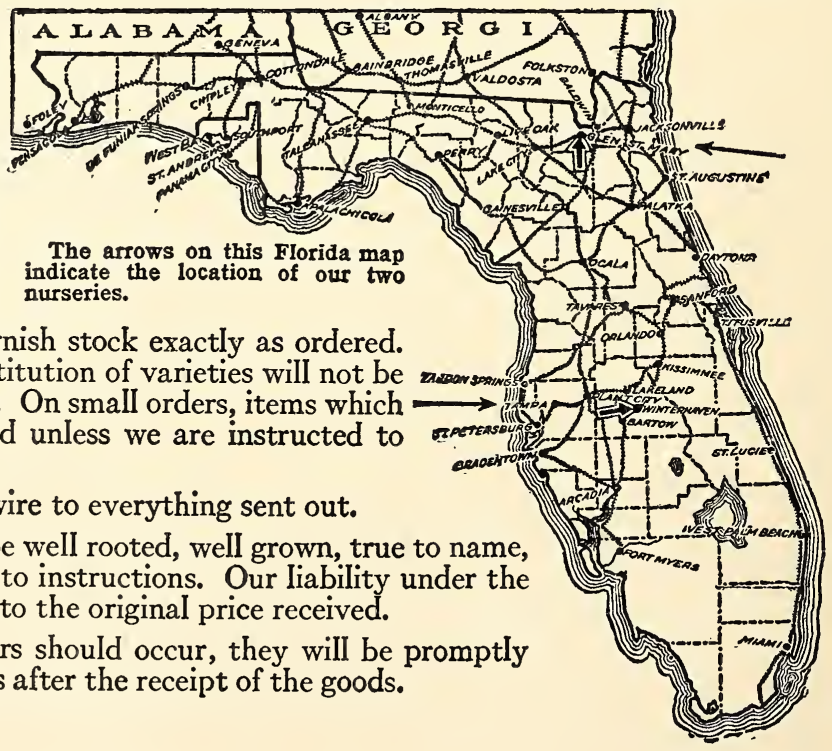

Substitution.-It is our desire to furnish On orders for commercial planting, substitution of varieties will not be we are unable to supply will be omitted unless we are instructed to substitute.

Printed Labels attached with brass wire to everything sent out.

We Guarantee all stock sent out to be well rooted, well grown, true to name, properly packed, and shipped according to instructions. Our liability under the foregoing guaranty is limited in amount to the original price received.

Claims.--If, by any possibility, errors should occur, they will be promptly rectified, if claim is made within ten days after the receipt of the goods. 


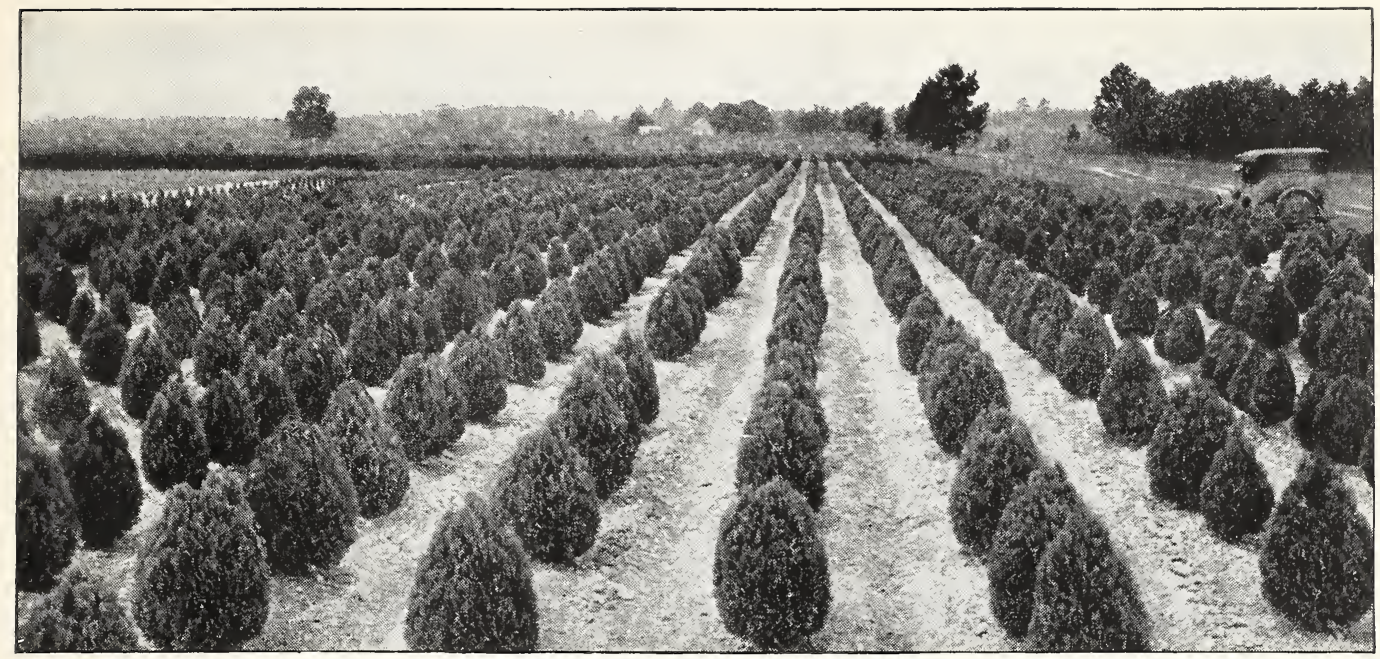

ONE OF THE ARBORVITE FIELDS

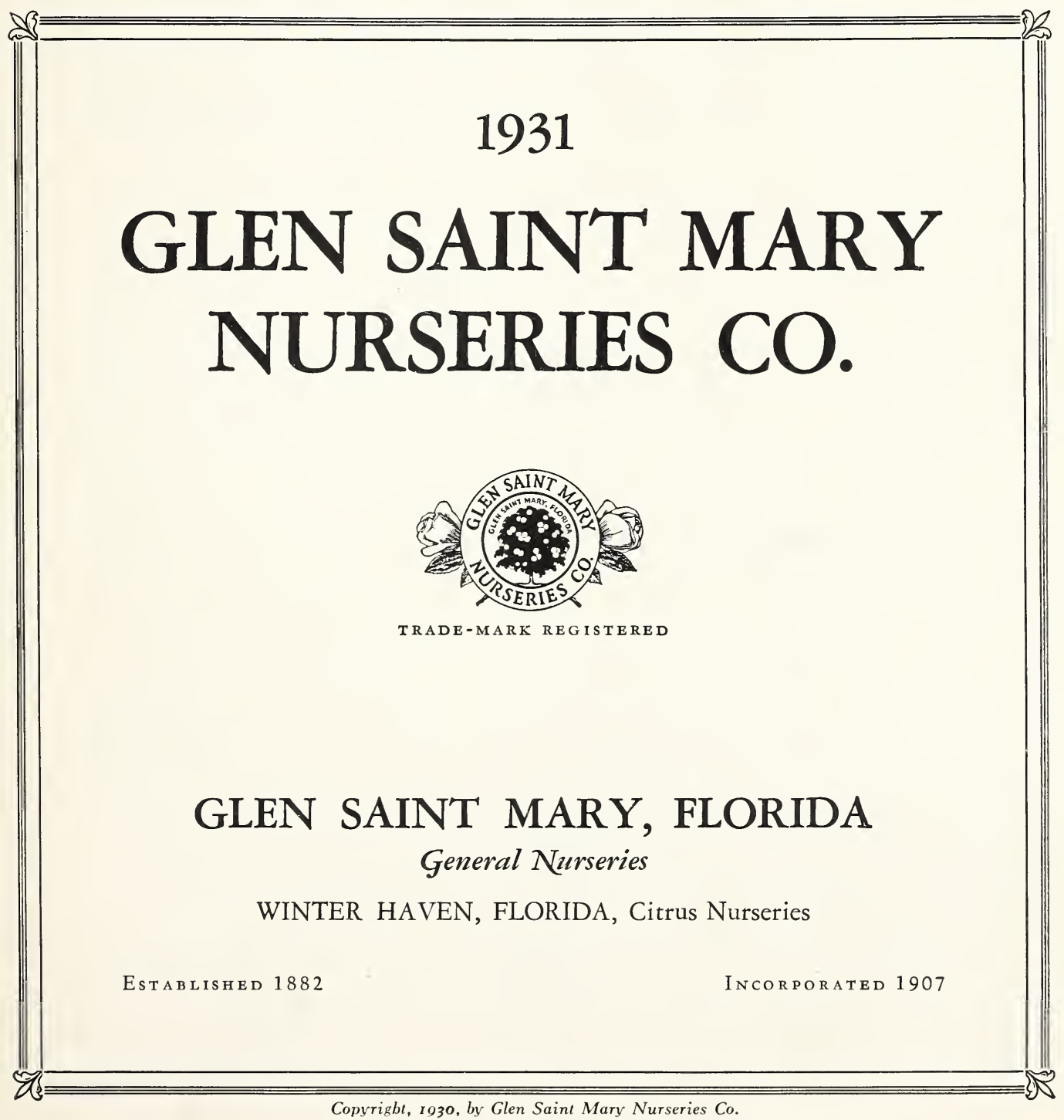



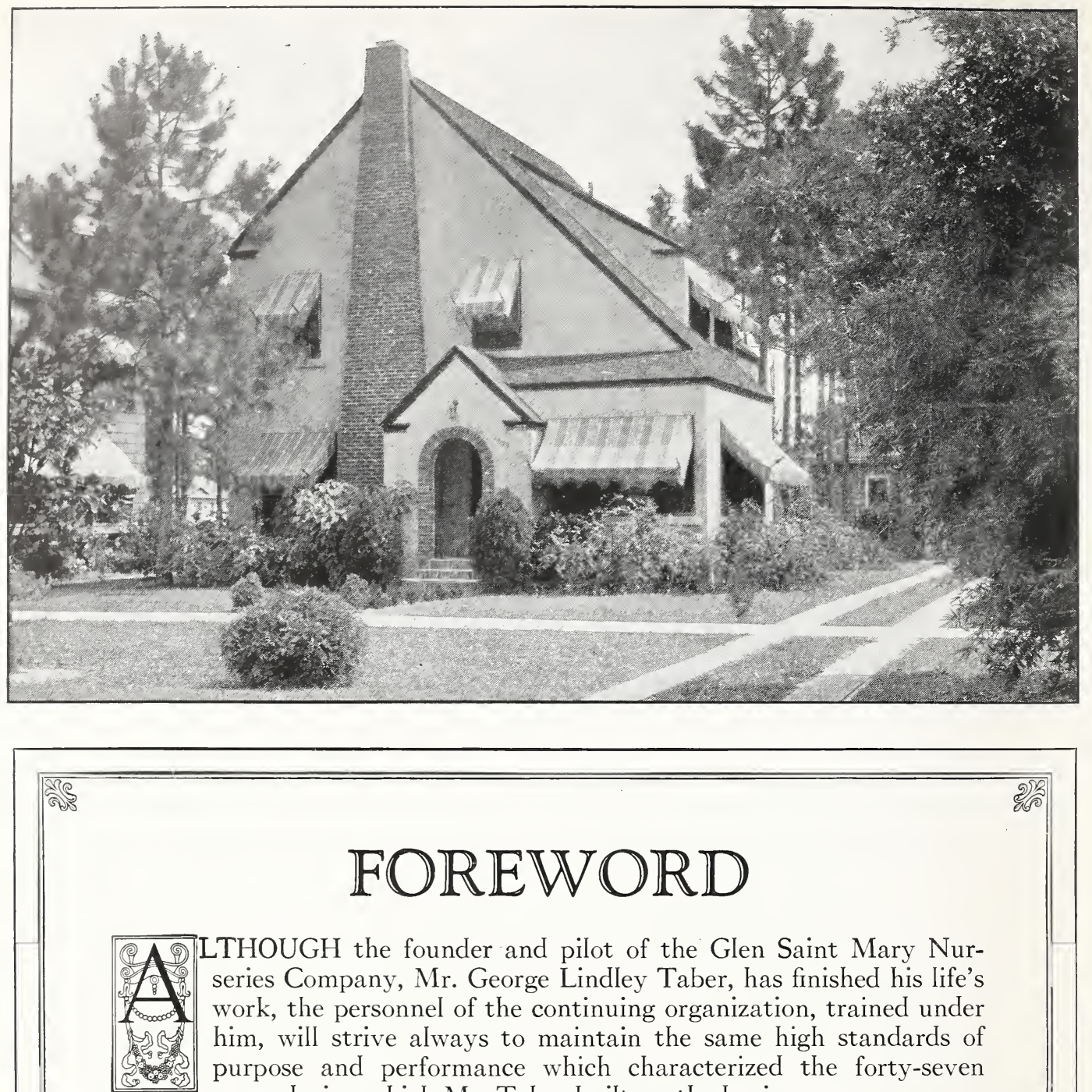

(2) (9)

THOUGH the founder and pilot of the Glen Saint Mary Nurseries Company, Mr. George Lindley Taber, has finished his life's work, the personnel of the continuing organization, trained under him, will strive always to maintain the same high standards of purpose and performance which characterized the forty-seven years during which Mr. Taber built up the business.

As in the past, earnest effort will be directed toward the introduction and presentation of the fruits and plants best adapted to the South. The knowledge gained through continuing exhaustive experimentation will always be at the command of our friends. We pledge ourselves toward that continuous improvement in service which is increasingly important in cementing the friendships of business.

We meet the 1930-31 season with a greatly increased range and stock of the ornamental plants which have become so essential to home decoration in the South. We continue the extensive production of fruit trees, selected with the utmost regard for quality and grown with the elaborate attention to detail that has always been characteristic of the Glen Saint Mary Nurseries.

It is under these hopeful conditions that we expect to serve our friends and to deserve their continued patronage.

October 1, 1930

GLEN SAINT MARY NURSERIES CO. Glen Saint Mary, Florida 


\section{Azaleas}

MONG flowering shrubs, the Azaleas are surpassed by none. The colors of the flowers are rich and varied-scarlet, carmine, crimson, rose-pink, lavender, white, and variegated in the Indian and Kurume varieties, orange, pink and white in the native kinds, all in all, a very riot of color. The profusion of bloom is so great that the leaves of the evergreen sorts are hidden, and a well-grown plant when in flower is a solid mass of color. In the latitude of northern Florida, the blooming season covered by a succession of varieties is very long, lasting from September to June, with the greatest burst of bloom in February and March. Some varieties alone have a blooming season of sixty to ninety days, depending upon weather conditions. When not in flower, the evergreen Azaleas are good green shrubs, the equal of many others often planted for green color alone. Usually they grow to a height of 4 to 5 feet, but may be kept much lower by timely pinching and pruning.

They are adapted to and may be successfully grown over a Iarge area, extending from Charleston, S. C., down along the coast to south-central Florida and around the Gulf Coast into Texas. In this region they stand unequaled among flowering shrubs.

They are easily transplanted and not difficult to grow, provided certain requirements are met. Once the conditions are made right for them, there are no shrubs more easily kept in good condition. Azaleas will not flower well in dense shade, but partial shade or shade for half the day is all right. Shade has some advantage in that it is a protection against damage from cold in certain sections. FuII sunshine suits them well and in the sun they grow and blossom to perfection. Azaleas may be used as specimen or accent plants and set in the foundation planting, in the shrubbery border, or in beds by themselves. Most Azaleas are set out between October and June, but if carefully handled they may be planted any month in the year.

Soil conditions must be to their liking. The earth in which they are planted must be acid and bountifully supplied with vegetable matter, preferably secured from peat, muck, or rotted leaves. Such materials help to maintain an even supply of moisture, besides supplying the kind of plant-

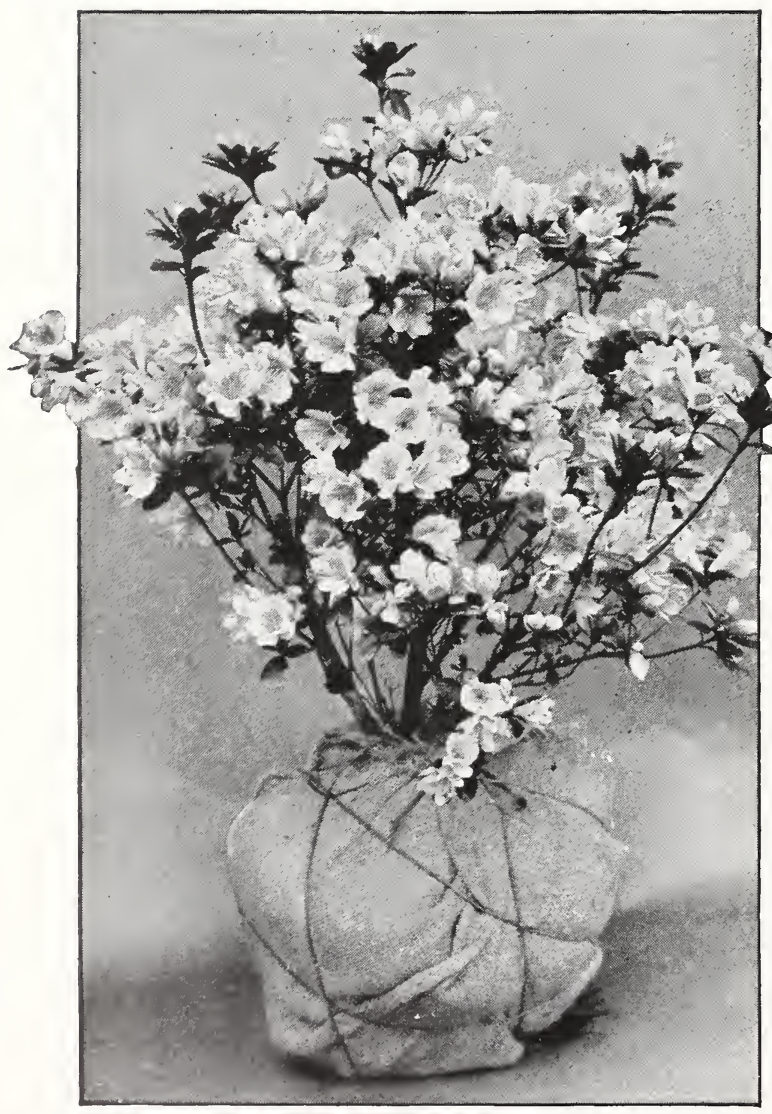

Kurume Azalea plant, lifted and burlapped for shipment For description and prices, see page 8 food they like. Lime or an alkaline soil is poisonous to them. If lime is present, it must be removed before planting. This is best done by digging out the soil and filling in with the right sort of materials. Whether lime is present or not it is best to plant Azaleas in specially prepared beds filled with suitable soil. Remove the earth to a depth of 8 inches, dig up and Ioosen by spading 4 inches more. Fill in 6 to 7 inches with peaty muck such as may be found around the edges of fresh-water ponds or streams, or use mold and leaves from beneath oak and other hardwood trees. Natural, moist, flat woods soil is also suitable for filling in an Azalea-bed. Add one pound cottonseed meal for each 10 square feet of surface and rake it in.

The drainage must be good and the bed must be located where all surplus rainfall will run off quickly. Azaleas delight in a moist soil but they will not tolerate a water-saturated soil-condition. Even a few days of it will often injure them beyond recovery.

Plants of Azalea indica should be set 2 to $31 / 2$ feet apart and after a number of years some of them can be taken out and moved to another location. They should be set no deeper than they grew originally. After planting, water thoroughly, and, for the first few months particularly, waterings should be carefully attended to and the tops of the plants should be syringed with water from time to time. A mulch of about 3 inches of oak leaves should be maintained, and as soon as one coating has rotted down partly, another should be added to bring it up to the original level. Do not remove the leaves when fertilizer is applied, but 


\section{Glen Saint Mary Nurseries Co. Glen Saint Mary, Florida}

\section{AZALEAS, continued}

scatter it over the surface, wash it in with water, and add more leaf-mulch. The fertilizers which may be used to advantage are peaty muck, castor pomace, and cottonseed meal. All of these furnish ammonia and will give good results. One pound per bush $2 \frac{1}{2}$ feet high, scattered over the mulch during early April, is about right. If the condition of the plants requires it, another pound may be given in June. Aluminum sulphate, at the rate of a 4 -inch pot full to a wheelbarrow fuII of soil or peat, is a great help in keeping the soil acid. It may also be used separately as a surface dressing, scattered over the ground where the plants are growing at the rate of 4 to 8 ounces to a square yard. This treatment is particularly beneficial if the plants have been injured by lime. When leaves become a sickly yellow with dark green veins, lime injury is indicated. If weeds appear, have them pulled out. Do not cultivate the plants.

Azaleas require little or no pruning, but the number of flowers a bush will produce may be greatly increased by pinching out the tips of the new twigs and branches between June and the middle of August. Do not pinch back later than the last-mentioned date, as the flower-buds are formed in late summer or early fall.

Insects are not often troublesome. Red spiders sometimes gain a foothold. Their presence may be detected by a pronounced browning of the leaves. Thorough frequent syringing of the plants with plain water will go a long way toward keeping them down. If additional treatment is necessary, dust carefully with a dust composed of 8 parts flowers of sulphur, 1 part nicotine sulphate dust, and 1 part powdered arsenate of lead, weIl mixed together. Two applications at an interval of ten days usually cleans them out completely. This will also take care of any leaf-eating insects.

At Glen Saint Mary Nurseries there has been brought together one of the largest collections of Azaleas to be found in America. The collection contains many rare and interesting varieties, some of which have originated here. During their blooming season, particularly in February and March, they are a wonderful sight. For the most part these belong to two groups, the Indian and Kurume Azaleas. Besides these, three native Azaleas, A.austrina, A. canescens, and A. serrulata, are grown. The two first mentioned are among our finest deciduous spring-flowering shrubs and worthy of a place in any garden.

\section{Indian Azaleas (Azalea indica)}

The so-called Indian Azaleas are evergreen shrubs of good form and habit, and the Iargerflowered varieties produce blooms measuring as much as 4 inches across. During their blooming season, well-grown specimens are a gorgeous sight, unrivaled in their color mass by any other flowering shrubs.

They vary greatly in rate of growth. Most varieties are twiggy, dense, and compact in habit. A few are openly branched and spreading, though they may be made thick-headed by timely pruning. Some kinds are slow of growth, practically dwarf, while others grow into large shrubs.

The colored pages in this section give some idea of the rich colors of the Indian Azaleas.

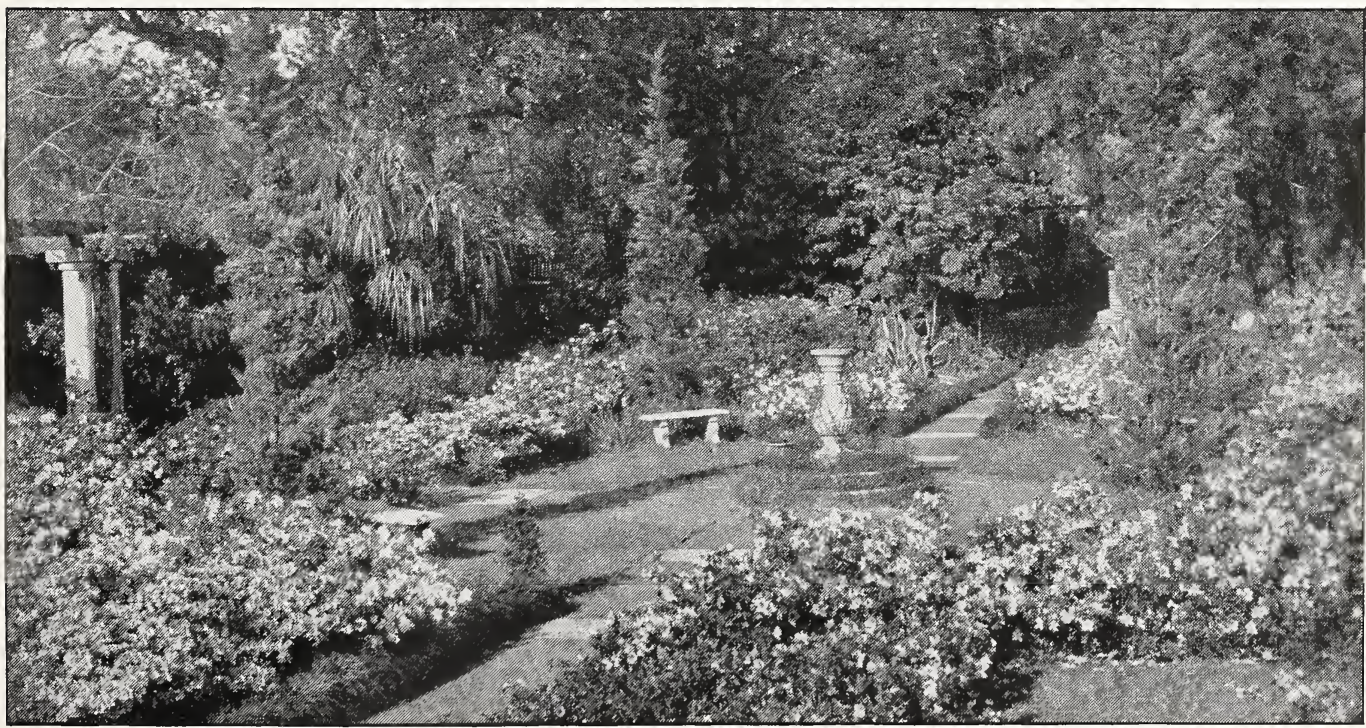

Only Azaleas could give this lovely formal garden such wealth of bloom and color 


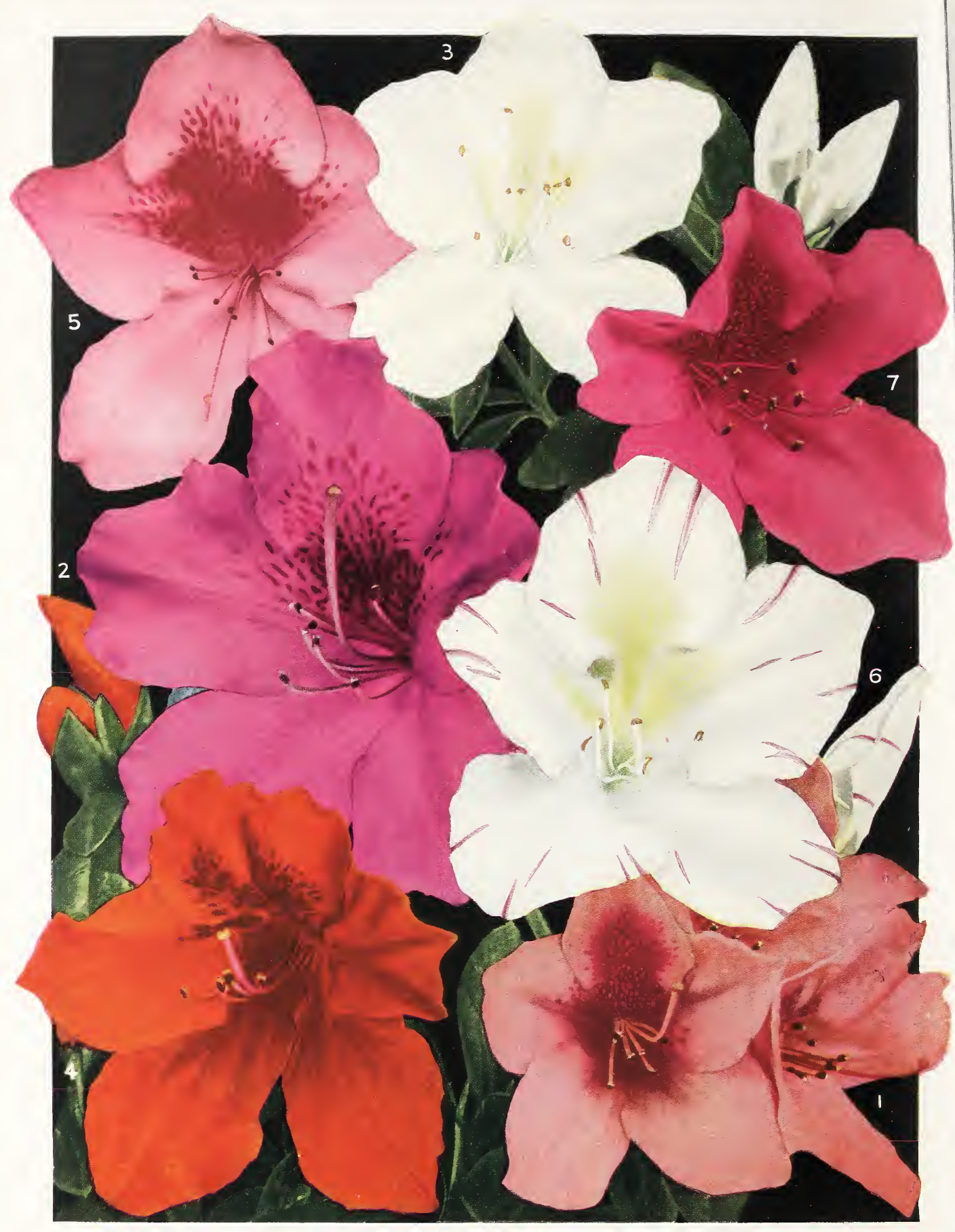

SOME INDIAN AZALEA VARIETIES

I, Salmon; 2, Lavender; 3, White; 4, Scarlet; 5, Pink; 6, Variegated; 7, Rose-Red

Our collection of Azaleas is so large that only a suggestion of their wonderful colorings can be given. This plate gives a slight idea of the range of vivid shades, but to appreciate fully their great variety and wondrous beauty these plants have to be seen in bloom. While the season varies from year to year, great numbers may be seen in bloom at Glen Saint Mary Nurseries from February 15 to March 25, and visitors are always welcome. 


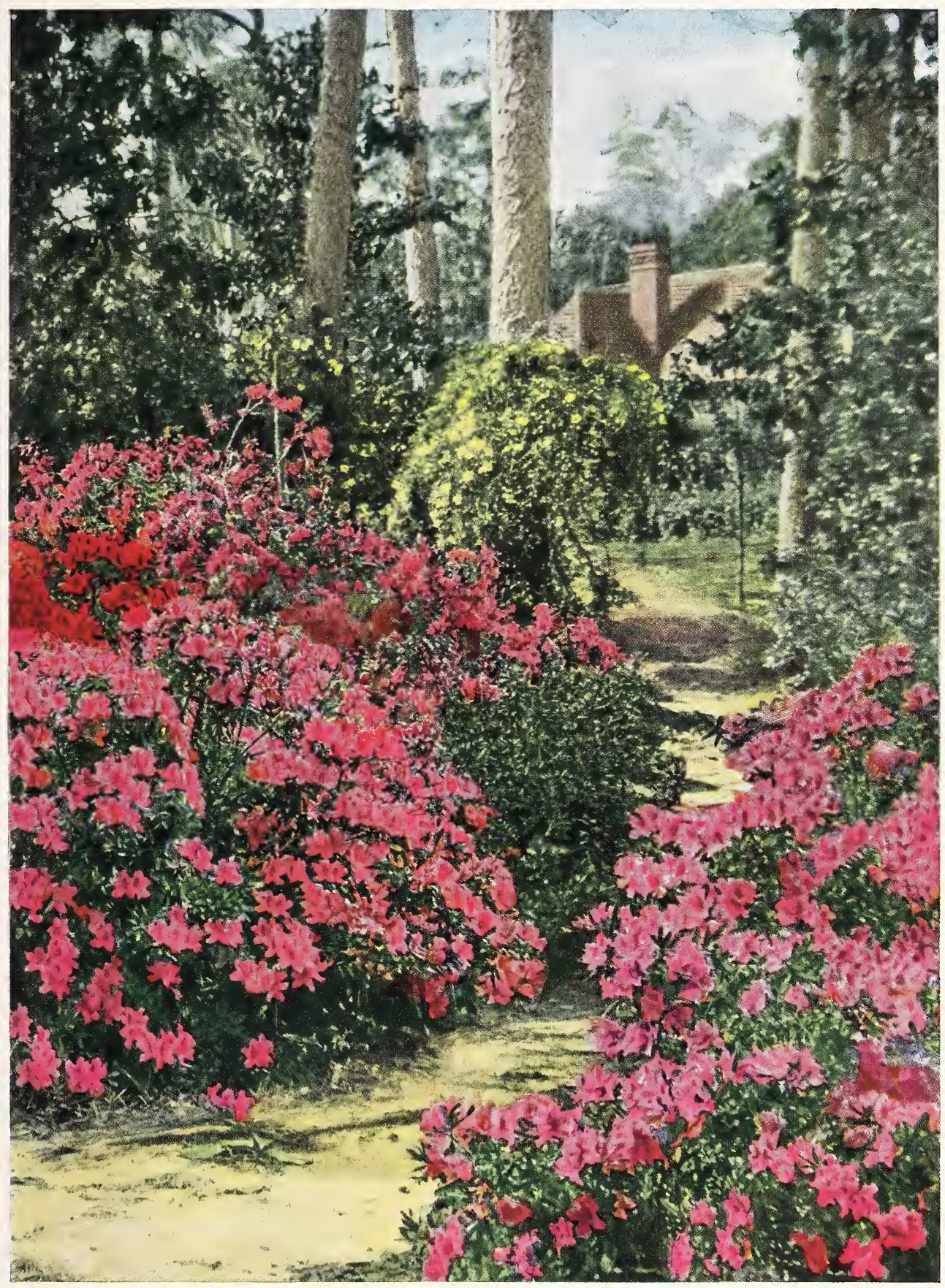

An Azalea-garden in bloom is a gorgeous sight

For natural garden planting, Azaleas are unequaled. No other shrubs adapted to the same area in the South give so much bloom, in so many colors and shades. They come into bloom during the winter and early spring months when flowering plants are most prized. They live on from year to year, increasing in size and beauty. 
INDIAN AZALEAS, continued

Seven different colors or shades are listed, SaImon, Lavender, White, Scarlet, Pink, Variegated, and Rose-red. In addition to these there are many more, and a study of our collection when in bloom will reveal many interesting variations.

PRICES ON INDIAN AZALEAS. Salmon, Lavender,

White, Scarlet, Pink, Variegated, and Rose-Red.

Each Per 10

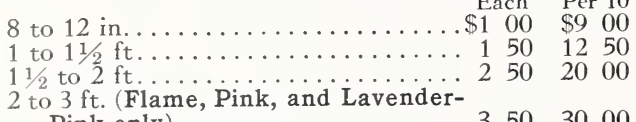
Pink only).

\section{Kurume Azaleas}

\section{Azalea obtusa japonica}

These Japanese Azaleas are a very valuable addition to our list of flowering shrubs. They are characterized by very thick heads, small leaves, and smaIl flowers in dense clusters. The flowers make up in numbers what they lack in size, and when in bloom, well-grown plants are a solid mass of color. No shrubs surpass them. Their blooming season is during February and March.

Though of rather slow growth, they make goodsized specimens, and their compact form makes them the equals of other evergreen shrubs, even when they are not in flower. Very small plants wiIl bloom, and each season as they increase in size they increase in beauty.

Many new and different colors, not present in other Azalea groups, are found in this class. There are white, white shaded pink, pink, lavender, carmine, scarlet, rose-red, salmon, and variegated varieties. Most of them are singleflowered, but some are hose-in-hose, i.e., one perfect flower set inside another.

As a group, the Kurume Azaleas are no more difficult to grow than any others. Many kinds have been tested and all found to be well adapted to all that area in which the Evergreen Azaleas may be grown in the open garden. They are very hardy, and, as a rule, withstand more cold without injury than most of the Indica varieties.

PRICES ON KURUME AZALEAS. In shades of Pink, Lavender, Salmon, White and Variegated.

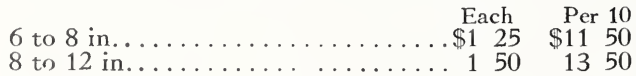

\section{Amoena Azalea}

\section{Azalea amona}

This densely branched Evergreen Azalea is closely related to the Kurumes. The leaves are small, rounded, and shining and the flowers small, hose-in-hose, Iavender-pink, and produced so abundantly that they completely cover the bushes in early spring. It is a very satisfactory Azalea, hardy throughout the South.

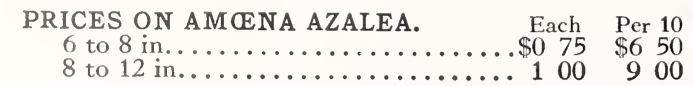

\section{Native Azaleas}

The native Azaleas, commonly called "Wild Honeysuckles" in the South, are all deciduous shrubs. The three species native in Florida are carried in stock. These are Azalea austrina, Azalea canescens, and Azalea serrulata.

Azalea austrina (Florida Flame Azalea). This beautiful Azalea, native in northwestern Florida, blooms in March and April. The spicy-scented flowers vary in color from light yellow through orange to orange-red. Plants grow to a height of 8 to 10 feet.

Azalea canescens (Native Azalea; Wild Honeysuckle). The most common of the native Azaleas and is found throughout northern Florida and southern Georgia, growing on moist, but welldrained acid soil. The trumpet-shaped flowers are usually light pink in color, but white-flowered and deep pink specimens are sometimes found. They grow to large size, but are readily kept at any desired size by pruning. The blooming season is in February and March.

Azalea serrulata (Summer Azalea). This Azalea is widely distributed in Florida, but nowhere common. The pure white flowers open in June, July, and August.

PRICES ON NATIVE AZALEAS-A. austrina, A. canescens, and A. serrulata.

Small clumps Each Per 10

Medium clumps, 3 to $4 \mathrm{ft} \ldots \ldots \ldots \ldots 250 \quad 2250$

Strong clumps, 4 to $6 \mathrm{ft} \ldots \ldots \ldots \ldots 500 \quad 4500$

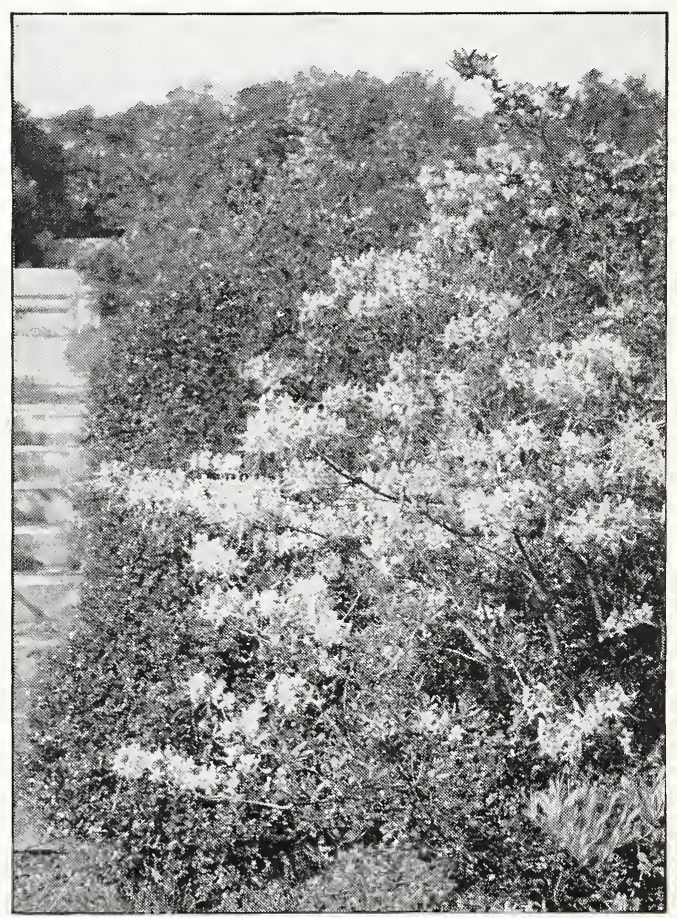

Azalea canescens 


\section{Glen Saint Mary Nurseries Co. Glen Saint Mary, Florida}

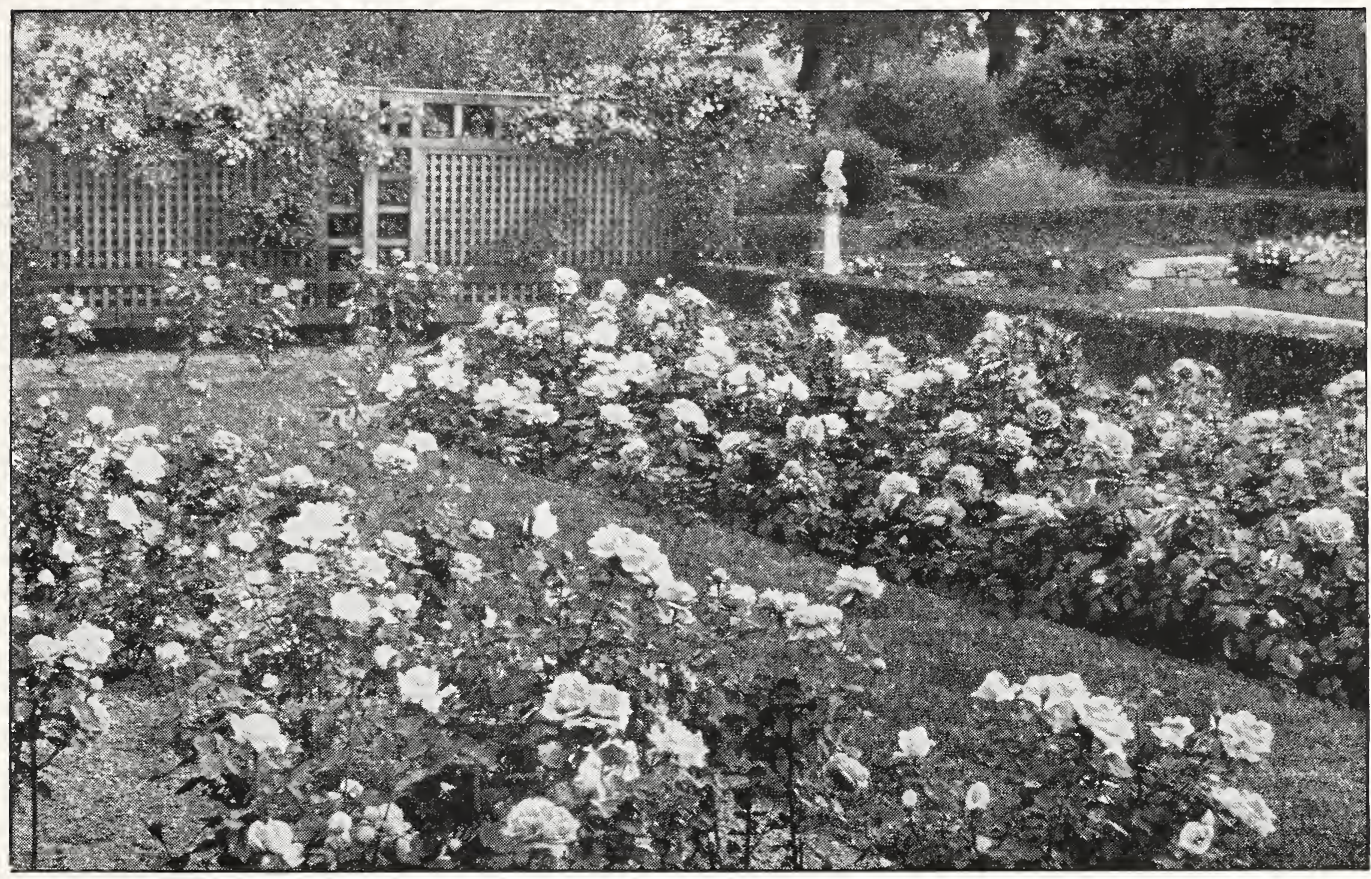

\section{Roses}

"T HAVE always believed that the happiness of mankind may be increased by encouraging that love of a garden, that love of the beautiful which is innate in us all," and in the development of the garden no plant is more worthy of a large place than the Rose. In what wonderful shades and colorings, in what exquisite variety of form and habit, with what delicate perfume it is now possible to have them! For length of blooming period they have few equals and no superiors among flowering shrubs - the Rose stands in a class by itself - the Queen of Flowers.

The growing of quality Rose bushes has been an important part of our nursery work for over thirty years, and, naturally, during this period of time we have learned something about Roses and how to grow them. It has never been our object to grow long lists of varieties. Rather it has been our conservative plan to offer our customers a short list of known and tried varieties. This does not mean that we are not constantly testing out new varieties, but we are not willing to experiment on our customers by offering them untried sorts. In consequence, our lists have varied but little from year to year, and when a new variety appears in our catalogue, it is an indication that it has been very thoroughly tested for several seasons previous. The old favorites remain, they are not displaced; only new ones of known and proved merit are added.

Our Roses are grafted and budded plants. It usually takes three years to produce them. Roses on their own roots, with few exceptions, are useless in the Lower South, and we do not grow them.

\section{Varieties}

Roses are divided into a number of groups, based upon their origin, or the species from which they came. Those best adapted to the Lower South belong to the Tea (T.) and Hybrid Tea (HT.) groups. These Roses can be depended upon to give flowers almost continuously, or as Iong as they continue growing. They are the most important groups. The Bengal Roses, represented by such varieties as Louis Philippe and James Sprunt, and the Noisette Roses represented by Estelle Pradel, Lamarque, Marechal Niel, and Woodland Margaret, are also free-flowering groups. Hybrid Perpetuals (HP.) can be depended upon as a rule for two bursts of bloom, one in early spring and another in late fall, though careful and severe pruning is necessary to secure them. Frau Karl Druschki, that gorgeous white sort, belongs to this group, but is everblooming in its habit in the Lower South. As a rule, the Ramblers are failures, except the dwarf sorts. Of these, Baby Rambler blooms continuously throughout its growing period. The Cherokee Roses, of Japanese origin, are thoroughly at home. This group in our catalogue consists of four varieties, Anemone, Fortune's Yellow, Ramona, and White Cherokee. 


\section{Soils and Preparation}

Soils in the South are variable, perhaps in some districts more so than in other parts of the country, hence it is difficult to lay down general rules for soil-preparation. Locations under the

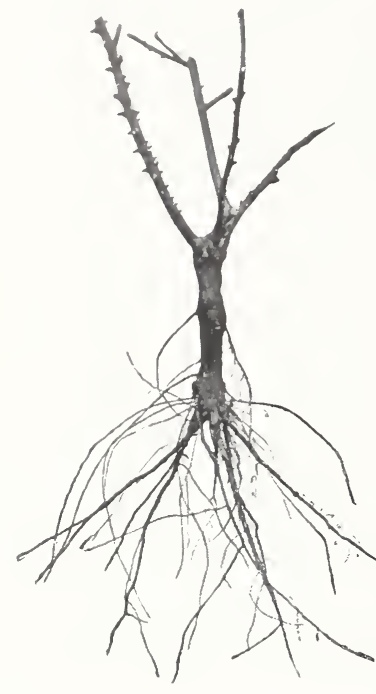

shade of trees, or where the ground is filled with tree-roots, should be avoided. Wet soils should be drained. The Rose delights in a moist soil, but standing water or a soil completely filled with water for a period of time is certain to prove harmfuI. C I a y lands need little preparation, except to enrich them and make them less compact and more friable. The addition of 2 to 3 inches of peat moss, good muck, or woodsmold will help greatly. These can be spread over the surface and spaded in. Stable manure, wellrotted, is also good. Sandy soils can be improved by adding clay wherever possible and with it peat moss, woods-mold or stable manure. Closely planted beds may be prepared by digging out 15 inches deep, and filling in with 4 to 6 inches of good clay and finishing off with 9 inches of a well-mixed soil, composed of garden soil or woodsmold, stable manure, and one to two pounds of bone-meal for each plant. It is best to make up the beds two to three weeks before planting. Bushes budded or grafted on vigorous-growing stocks overcome many of the drawbacks of Rosegrowing. On light soils, Roses worked on vigorousgrowing roots should always be used. For particularly trying situations, Roses on Cherokee stock should be given preference. We recommend it for those conditions where it is difficult to bring Roses to perfection.

\section{Planting}

"The finest effects are secured by planting a dozen Roses of one kind, for instance, rather than by planting an equal number made up of several different varieties."

The planting season in the South is from December 1, or as soon as the plants are dormant, through the winter and spring months to about April 15. When the plants are received, it is well to set them in buckets of water overnight, if they have been delayed in transit, or bury them completely for a day or two in moist soil. They are already pruned for planting, but any broken roots should be trimmed off. Our grafted plants should be set with the graft union 3 to 4 inches below the surface.
PLANTING, continued

Space them 2 to $21 / 2$ feet apart. Spread the roots out carefully, fill in with good soil mixed with bone-meal, pack the earth tight about the roots, leave a basin, and water weII.

\section{Fertilizing and Care}

Thorough preparation of the soil before planting will take care of the fertilizing problem for some time, but as Roses are gross feeders, it is necessary to keep them supplied with an abundance of plant-food. Stable manure may be used, liberally scattered on the surface as a mulch, and good, well-balanced commercial fertilizer may also be used from time to time. A mulch of 3 to 4 inches of leaves or partly rotted leaves and Ieafmold is excellent, particularly during the summer months. During dry weather, water freely.

Tea Roses do not require very severe pruning. Prune in September and October for fall and winter bloom; in Iate February and March for the spring crop of flowers. Thin out smaII and poorly developed wood. Cut Hybrid Perpetuals severely, leaving only 3 to 4 inches of the old canes. Climbers should be pruned sparingly.

Shoots sometimes come up from the stock below the graft union and take the food-supply to such an extent that they destroy the Rose top. The leaves on these shoots generally have seven leaflets and are quite different in appearance. They should be removed by digging down to the point of union with the stem and cutting them off smooth and clean.

\section{Pests}

The pests which cause most trouble in Rosegrowing are aphis and thrips, black-spot and powdery mildew. Sooner or later some one of these is likely to appear, and the Rose-grower should be prepared to take care of them.

Aphis or green plant-lice attack the new growth whether of bud or shoot. They are sucking insects. Thrips are usually noticed in the flowers, though they also work on the new growth. They are the cause of flowers failing to open, turning brown and withering up. Some varieties are much more affected by thrips than others. Aphis may be removed by syringing thoroughly with water from the hose. Both of these Fests can be weIl handled by spraying with a mixture of one pound of laundry soap and one ounce of Black-Leaf 40 , or other tobacco extract, to 8 gallons of water. Dissolve the soap in the water by boiling, add the Black-Leaf 40, and spray thoroughly. In treating the plants for thrips, prune off all open and partly open flowers early in the morning before spraying; handle the prunings carefully and place them in a bucket of water with a quarter inch of kerosene floating on the surface. Repeat this treatment in four or five days if the thrips appear again.

Black-spot appears as rather irregular dark areas on the leaves. These turn yellow and drop off. 


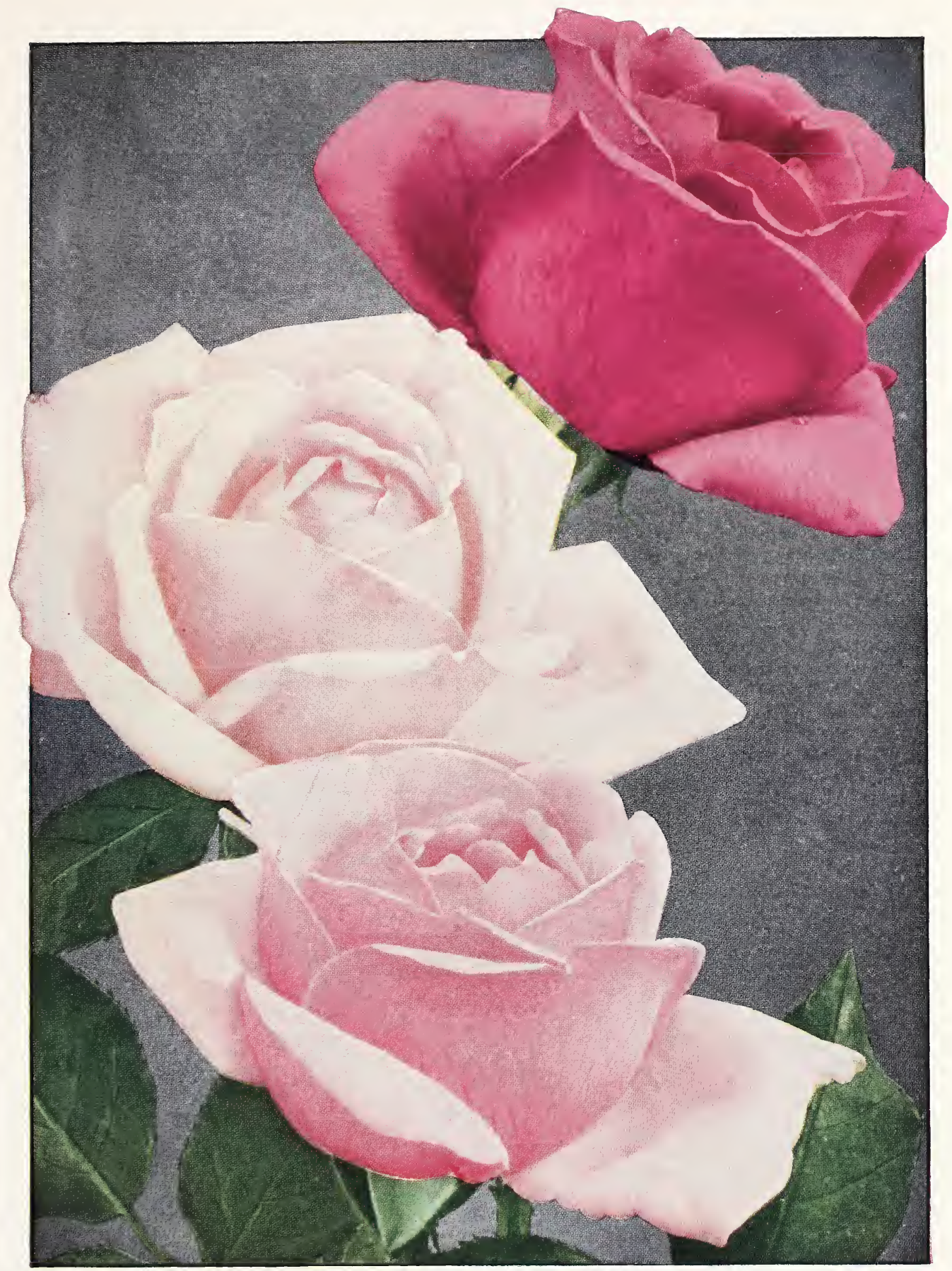

Top, Red Radiance: middle, Mrs. Charles Bell; lower, Radiance

When John Cook originated the Radiance Rose he conferred upon American Rose-growers a blessing that stands unequaled and from it have come two sports, Red Radiance and Mrs. Charles Bell. Among bush Roses adapted to southern conditions, these three are without rivals. They are unsurpassed in vigor of growth, in profusion of bloom, in shape, color and substance of flowers, in freedom from disease. Bushes of these three varieties from Glen Saint Mary Nurseries have gladdened the gardens of the South for many years. 
Powdery mildew is a white powdery growth which appears on the young leaves and shoots. If it can be had, the best spray is potassium sulphide, 1 ounce to 2 gallons of water, or use Bordeaux Mixture or a bordeaux compound. Spray at intervals of a week or ten days until the disease is checked.

Note.-Roses are handled in severaI different ways at Glen Saint Mary Nurseries: They are dug with bare roots and shipped from November to March, inclusive. From April to October, inclusive, a limited number of varieties are availPRICES ON ROSES.

Grafted or budded, all varieties.

On Cherokee stock: Mrs. Charles Beil, Radiance, Red Radiance, Maman Cochet,

White Maman Cochet. ................................. 125 able in boxes: Mrs. Charles BeII, Radiance, Red Radiance, and White Maman Cochet. These boxes are easily taken apart for setting the plants in the open ground, hence it is possible to plant Roses at any time of the year. In addition to these methods of handling, Roses can be balled and burlapped and so shipped at almost any season. AII Roses are grafted or budded on vigorous-growing stocks. For especially difficult situations, a small number of varieties are grown on Cherokee stocks.

$$
\begin{array}{llc}
\text { Each } & \text { Per } 10 & 100 \\
\$ 065 & \$ 600 & \$ 5000
\end{array}
$$

100

\section{Description of Varieties}

\section{Yellow and Salmon Roses}

Chromatella. N., Climber.

This beautiful Rose is Iemon-yellow, with Iong, pointed buds. It flowers in great profusion and holds its foliage well.

Climbing Perle des Jardins. T., Climber.

There is no more satisfactory climbing Rose than this. In our opinion it is a better Rose than Marechal Niel, which it closely resembles. The new foliage is a beautiful wine-color.

Etoile de Lyon. T., Bush.

A lovely Rose with well-formed buds and Iarge, double yellow flowers. It is particularly fine in early spring and Iate fall. Has no superior in its class.

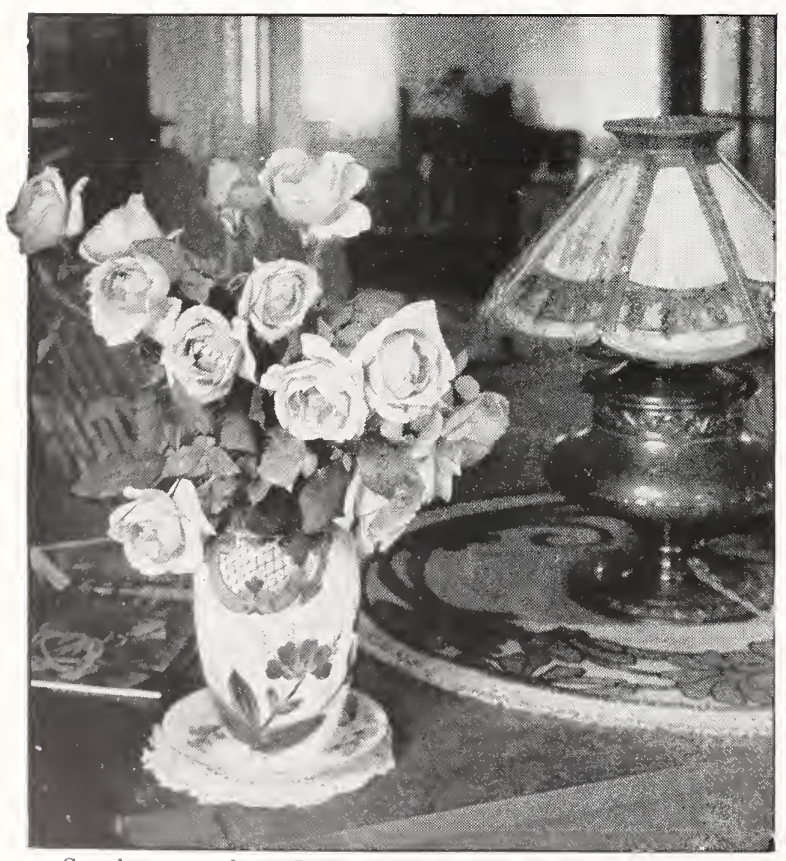

Southern outdoor Roses are of ten the equals of greenhouse blooms
Fortune's Yellow. Cherokee, Climber.

Blooms in April in northern Florida, produces a gorgeous mass of bloom over a period of about three weeks-a sight once seen, never to be forgotten. The color is variable, a rich blending of yellow, orange, and pink.

Isabella Sprunt. T., Bush.

A strong-growing Rose with dark green foliage and well-formed, light yellow buds that make one think of Safrano, except in color. It has much to recommend it.

Luxembourg. HT., Bush.

A very remarkable rich orange-yellow flower, with coppery shadows and creamy yellow tips. The plant is a profuse bloomer and very vigorous. The most generally satisfactory yellow Rose for the South.

Mlle. Franziska Kruger. T., Bush.

A very free bloomer; copper-yellow, shaded pink on the outer petals. A fine Rose for the early spring or Iate fall crop of flowers.

Marechal Niel. N., Climber.

Perhaps the most famous and most widely known Rose grown in the South. The flowers are a wonderful shade of clear deep yellow. Its only rival is Climbing Perle des Jardins.

Reve d'Or. T., Climber.

Produces flowers which closely resemble those of Safrano, but with greater substance when open. It holds its foliage weIl and is one of the best.

Safrano. T., Bush.

This is a strong-growing Rose, producing salmon-colored buds of exquisite shape and semi-double flowers. It is a profuse bloomer. A very old Rose, but always a favorite.

Solfatare. T., Climber.

The flowers of Solfatare are a clear sulphur-yellow, large, double, and well-formed. The foliage is very fine. It is a free bloomcr. 


\section{Glen Saint Mary Nurseries Co. Glen Saint Mary, Florida}

\section{White Roses}

Climbing White Maman Cochet. T., Climber.

A fine strong-growing white climber, with the flowers and foliage of White Maman Cochet. One of the best white climbers.

Devoniensis. T., Climber.

Sometimes called the "Magnolia Rose" because of the large size and substance of its blooms. It is, perhaps, the strongest-growing Tea Rose in our collection. The flowers are white, delicately shaded pink. It is a favorite with all who know it.

Estelle Pradel. N., Climber.

Produces its pure white flowers in great profusion. The blooms are of medium size.

Frau Karl Druschki. HP., Bush.

Buds fine and large, white, but sometimes shaded pink on outer petals. The open flowers are of great size and showing a cluster of deep yellow stamens at the center. A very strong-growing Rose and although a Hybrid Perpetual it blooms freely throughout the year.

Kaiserin Auguste Viktoria. T., Bush.

A free and regular bloomer from early spring to Iate faII. The flowers are pure white, of great substance, and are produced on long stems. This is one of the best southern Roses.

Lamarque. N., Climber.

A free-blooming white Rose with a tint of pale yellow. The foliage is dense, and altogether it is one of the best white climbing Roses.

Marie Lambert. T., Bush.

One of the best Roses for early spring flowers. The buds are beautifully formed and sweet-scented, while the flowers are pure white and of medium size. It is a strong grower with good, dark green foliage.

Marie Van Houtte. T., Bush.

One of the very strong-growing Roses in our list. The general color of the Rose is white, but tinted in the center with pale Iemon and on the outer petals with delicate pink. A wonderful Rose.

\section{White American Beauty.}

Same as Frau Karl Druschki.

White Cherokee. Cherokee, Climber.

A rampant climbing Rose, and when in flower in early spring it is an object of beauty and delight. Leaves evergreen, bright, and thorny.

White Killarney. HT., Bush.

Produces fine, long-pointed buds; the open flowers are semi-double. Best on Cherokee stock. It is a sport from Pink Killarney.

White Maman Cochet. T., Bush.

A sport from the pink variety of the same name. It is one of the finest in its class. The buds are long, often pointed, and of great substance, pink tinted on the outer petals, borne on long stems. It is one of the best varieties for cut-flowers. A strong grower with splendid foliage.

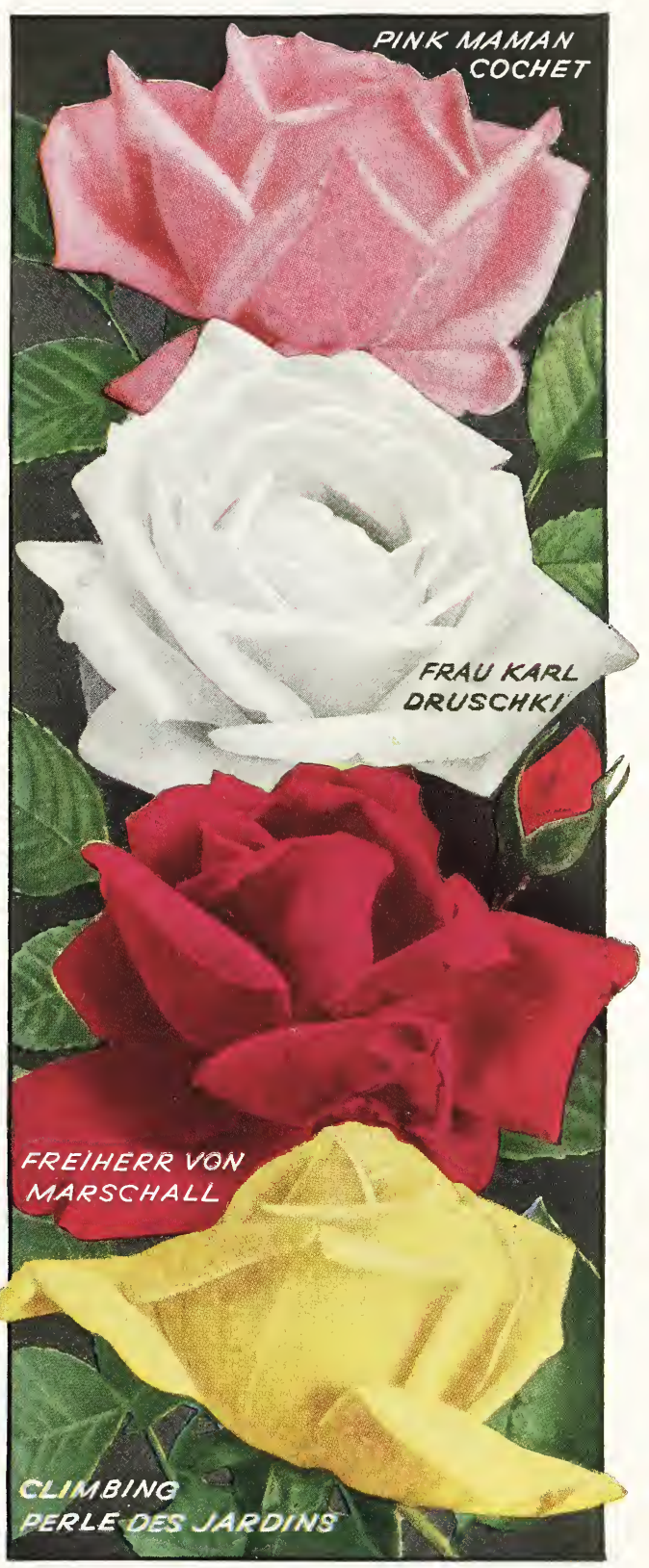

These are old-time favorites in pink, white, red and yellow. Maman Cochet is a fine pink Rose with beautiful buds in an unusual shade of pink; Frau Karl Druschki, a giant white; Freiherr von Marschall, a good grower with carmine-red flowers; while Climbing Perle des Jardins is a particularly fine climbing Rose that may be readily grown as a bush if some attention is given to pruning. 


\section{SOUTHERN PLANTING FACTS}

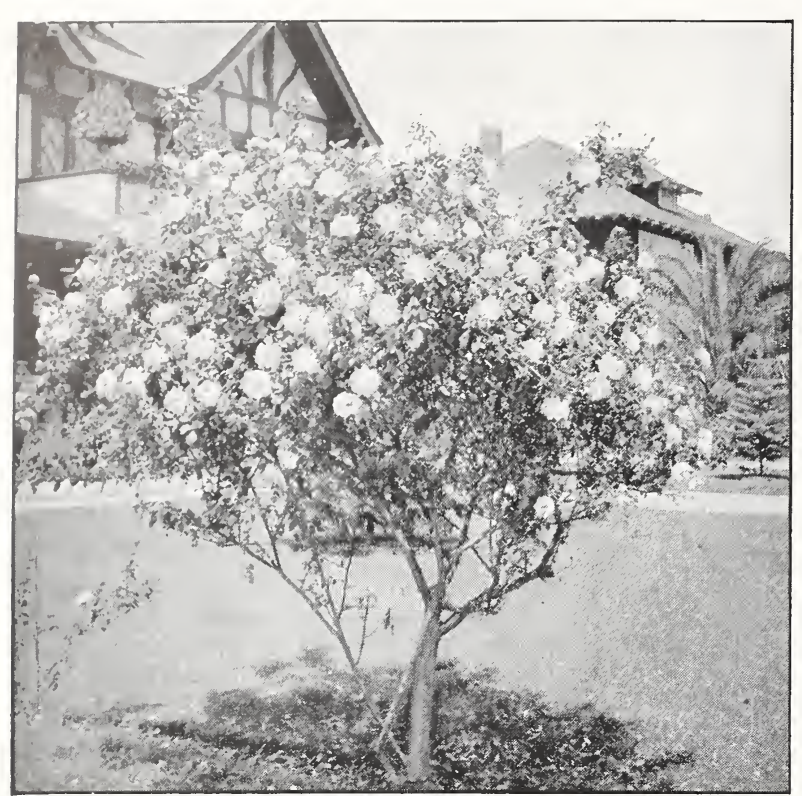

Mme. Lambard

\section{Pink Roses}

Anemone (Pink Cherokee). Cherokee, Climber.

This is a beautiful pink Cherokee Rose, with all the beauty of the group in its daintily shaded pink flowers. Its season of bloom is long for a Cherokee - three to four weeks - and scattering blooms are produced over a much longer period. Well adapted for planting in the South.

Anna de Diesbach. HP., Bush.

Large-flowered; beautiful shade of shell-pink. The buds are very fine and are produced on long stems. Looks somewhat like Paul Neyron.

Baby Rambler. Poly., Bush.

A dwarf variety producing continuously throughout its growing season clusters of small pink Roses. Color is a beautiful shade of pink.

Bon Silene. T., Bush.

A very free-flowering pink Rose. The flowers are colored in different shades of pink with deeper pink veining on the petals.

Climbing Bridesmaid. T., Climber.

Flowers of a delicate shade of lisht pink whick varies somewhat. They are large and fine, particularly during cooler weather.

\section{Climbing Maman Cochet. T., Climber.}

Its beautiful flowers and fine foliage are an exact counterpart of Pink Maman Cochet. Vigorous, and our best pink climber.

Climbing Radiance. HT., Climber.

Among bush Roses, Radiance is the most commonly planted variety in America. The climbing variety is its counterpart except in stature. It is a splendid Rose.
Duchesse de Brabant. T., Bush.

An old-time favorite with globular buds and flowers of clear light pink. A good grower, dense, bushy and very free-flowering.

Duchess of Sutherland. HT., Bush.

Large-flowered, on Iong stems, shellpink with darker pink veins, very strong grower. A satisfactory addition to our lists.

Letty Coles. T., Bush.

A strong-growing Rose, producing an abundance of beautifully shaded pinkish salmon flowers.

Mme. Jules Grolez. T., Bush.

Rather dwarf in growth, producing satiny pink buds and flowers of fine shape and clear coloring. Its wonderfully colored flowers are produced abundantly.

Mme. Lambard. T., Bush.

The strongest-growing pink Rose in our collection. The shade varies from clear light pink to a deeper tint, darker on the outside of the petals than on the inside. This Rose with a little care in pruning can be grown in tree form.

Mrs. Charles Bell. HT., Bush.

A sport from Radiance with the same vigorous growth and free-blooming habit. In color it is shell-pink with salmon shading at the base of the petals. It is just as fine a Rose as either Radiance or Red Radiance and its color makes it very lovely.

\section{Minnie Francis. T., Bush.}

Has flowers of unusual style-rather open. The buds are long and pointed. Color dark pink, in different shades. A strong grower.

Paul Neyron. HP., Bush.

The largest-flowering Rose of its color in our list. It is a beautiful shade of dark rose-pink. The flowers are produced on long stems. It is often mistaken for American Beauty.

Pink Killarney. HT., Bush.

A free-flowering bush of upright habit. The long-pointed, bright pink buds and large, semidouble flowers of exquisite shading are characteristic of Killarney. The flowers always attract attention for their size and great beauty.

Pink Maman Cochet. T., Bush.

Commonly known as Maman Cochet, but we have added the word "pink" to separate it from the white form. Beautiful pointed buds of great substance, borne on long stems. It is a wonderfuI shade of pink. One of the best for cut-flowers.

Radiance. T., Bush.

The finest pink Rose we know. No description can do it justice. The buds are rather rounded, the flower cup-shaped, a beautiful shade of soft carmine-pink, deeper on the outside than on the inside of the petals, large and sweet scented. As a cut-flower it has no superior. It is a strong grower; has made a reputation for itself wherever tried. 


\section{SOUTHERN PLANTING FACTS}

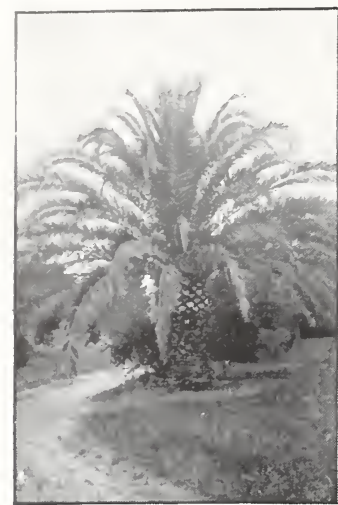

Phœnix canariensis

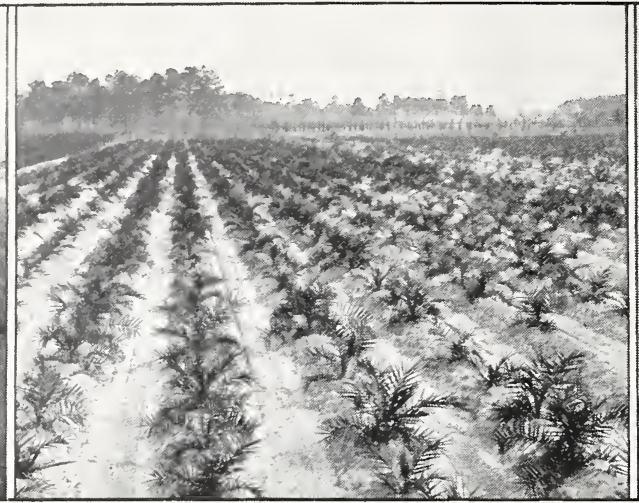

In the Palm Nurseries

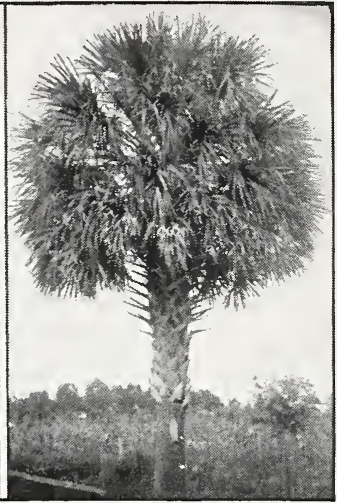

Sabal Palmetto

\section{Palms and Cycads}

$\mathrm{P}$ ALMS are among the most striking plants which may be used for outdoor southern planting. Their bare, single stems and huge, arching leaves separate them from all other plants. Wherever seen, weIl-grown specimens always attract attention and give a decidedly tropical touch to the grounds and to the landscape. As street and shade trees, they are excellent and worthy of much more extensive use. The varieties which we offer our customers will be found most satisfactory for outdoor planting. AII are pot-grown, or shipped with balls of earth, and may therefore be transplanted at any season of the year.

The place where a Palm is to be planted should be well prepared. The soil, if poor, should be thrown out, leaving a good-sized hole-30 inches square and deep is about right. Fill in with good, rich soil, carrying with it one-third well-rotted stable manure. Plant the PaIm in this hole without disturbing in any way the soil that comes about its roots, pack tightly into place, tie the fronds rather closely together to keep them from being tossed about by the wind, thereby loosening the plant in the soil, and water freely. Later, the strings about the fronds should be loosened, and in ten weeks or so may be removed entirely. Fertilize liberaily. Palms are gross feeders and require plenty of plant-food for their best growth. Stable manure and other organic fertilizers give splendid results.

\section{Cycads}

CYCAS revoluta (Sago Palm). A Palm-like Cycad, reaching a height of 3 to 4 feet, with a handsome crown of deep green leaves curved outward from the center; very hardy; grows weil out-of-doors in north Florida and along the GuIf Coast. Young plants have but a single stem; old ones are often branched. We have a particularly fine lot of these.

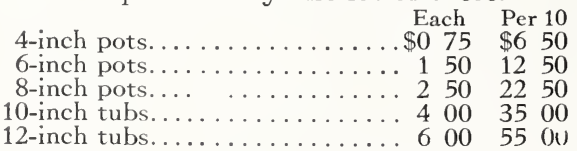

ZAMIA integrifolia (Coontie). This beautiful cycad is a native Florida plant. Its thick stem is almost entirely underground, while from its top the beautiful, tufted, dark green, fern-like leaves grow out to a height of about two feet. It is very satisfactory for use in low plantings in either sun or shade, and is weIl placed in the edges of shrubbery borders or of foundation plantings.

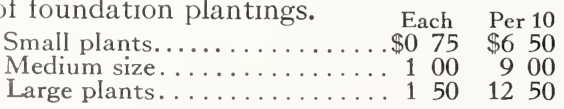

\section{Palms}

ARECA (Chrysalidocarpus) lutescens. A fine greenhouse and house Palm with arching, pinnate, dark green leaves and yellow stems; offshoots develop from the base, forming beautiful clumps. Also adapted for garden planting in the Far South.

4 -inch pots. $\begin{array}{cc}\text { Each } & \text { Per } 10 \\ \$ 100 & \$ 750\end{array}$

6 -inch pots. .............. $150 \quad 1250$

8 -inch pots............... 300

10 -inch tubs....................... 750

12 -inch tubs. ................... 00

14 -inch tubs...............1500

CHAMÆROPS excelsa (Chusan Fan PaIm). This PaIm has a rather slender trunk and flat, fan-shaped leaves borne on slender stems. It is one of the hardiest varieties known, and if any Palm will stand the winters of a given section out-of-doors, it will. It reaches a height of about 15 feet. Well-grown specimens are particularly handsome and graceful, and where a PaIm is desired for the small garden in the colder sections, it has no superior.

Each Per 10

4 -incí pots............\$100 \$7 50

6 -inch pots................ 150 


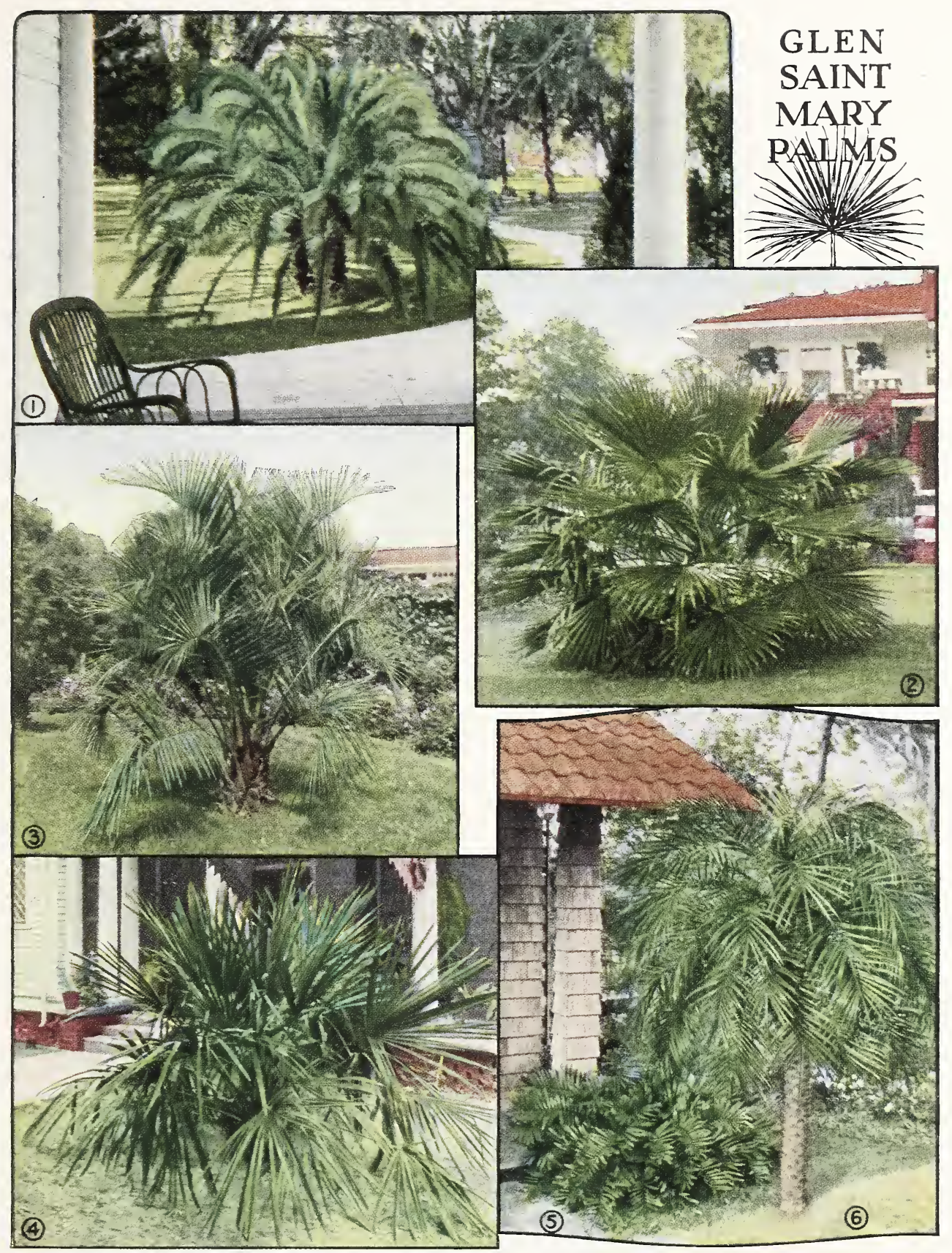

1. Phœenix canariensis

2. Washingtonia robusta
3. Cocos australis
4. Needle Palm

5. Zamia

6. Phœnix Robelin

Palms of many kinds are grown at Glen Saint Mary Nurseries-tender ones for house and porch use and for planting far south; hardy ones for planting out-of-doors. Palms of some sort are adapted to most of the Lower South. 


\section{SOUTHERN PLANTING FACTS}

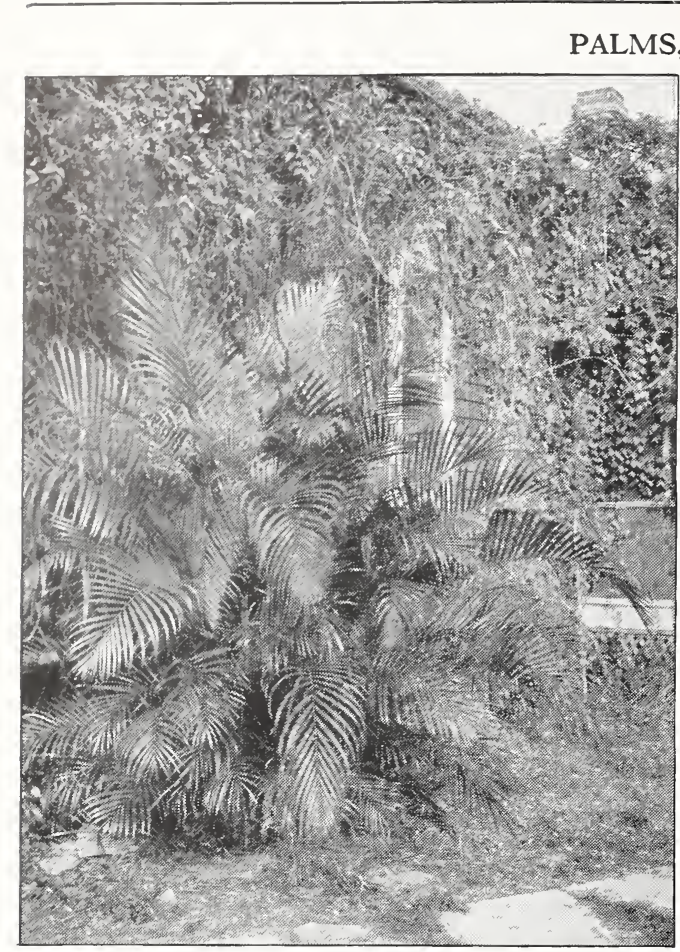

Areca lutescens. See page 16

COCOS australis. A very beautiful, hardy PaIm, with grayish green, curved pinnate leaves and growing to a height of 15 to 20 feet. Deserves to be widely planted as it is one of the most desirable PaIms.

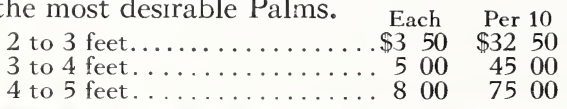

Cocos plumosa. This tree is one of the most beautiful of the PaIms, adapted to south Florida and similar sections. Trunk 40 to 50 feet high, smooth, about 12 inches thick, marked with rings; leaves erect and spreading, about 15 feet long. A fine PaIm for avenue and street planting.

$$
\begin{aligned}
& 6 \text {-inch pots........... Each } \begin{array}{r}
\text { Per } 10 \\
\$ 12 \quad 50
\end{array} \\
& 8 \text {-inch pots................ } 250 \quad \begin{array}{r}
\$ 12 \\
20
\end{array}
\end{aligned}
$$

LATANIA borbonica. One of the best fan PaIms for house use, and in central Florida and southward it is very satisfactory and grows well outdoors.

4 -inch pots.............\$1 $00 \quad \begin{aligned} & \text { Per } 10 \\ & \$ 750\end{aligned}$

6 -inch pots................. $150 \quad 1250$

8 -inch pots................. $200 \quad 1750$

OREODOXA regia (Royal PaIm). This PaIm, adapted to southern Florida and similar locations, is one of the most beautiful. The smooth gray trunk is enlarged at the base and surmounted by a plumy crown of graceful leaves 12 to 15 feet long. It is a rapid grower and reaches a height of over 100 feet.

$$
4 \text {-inch pots...........\$0 } \begin{aligned}
\text { Each } & \text { Per } 10 \\
\$ 650 &
\end{aligned}
$$

PHENIX canariensis. A stately PaIm, with large trunk and large, pinnate, gracefuilly curved leaves. A rapid grower; very hardy and one of the best for outdoor planting in the GuIf Coast country. This is the most widely planted of aIl the large-growing, pinnate-leaved PaIms.

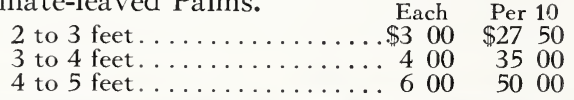

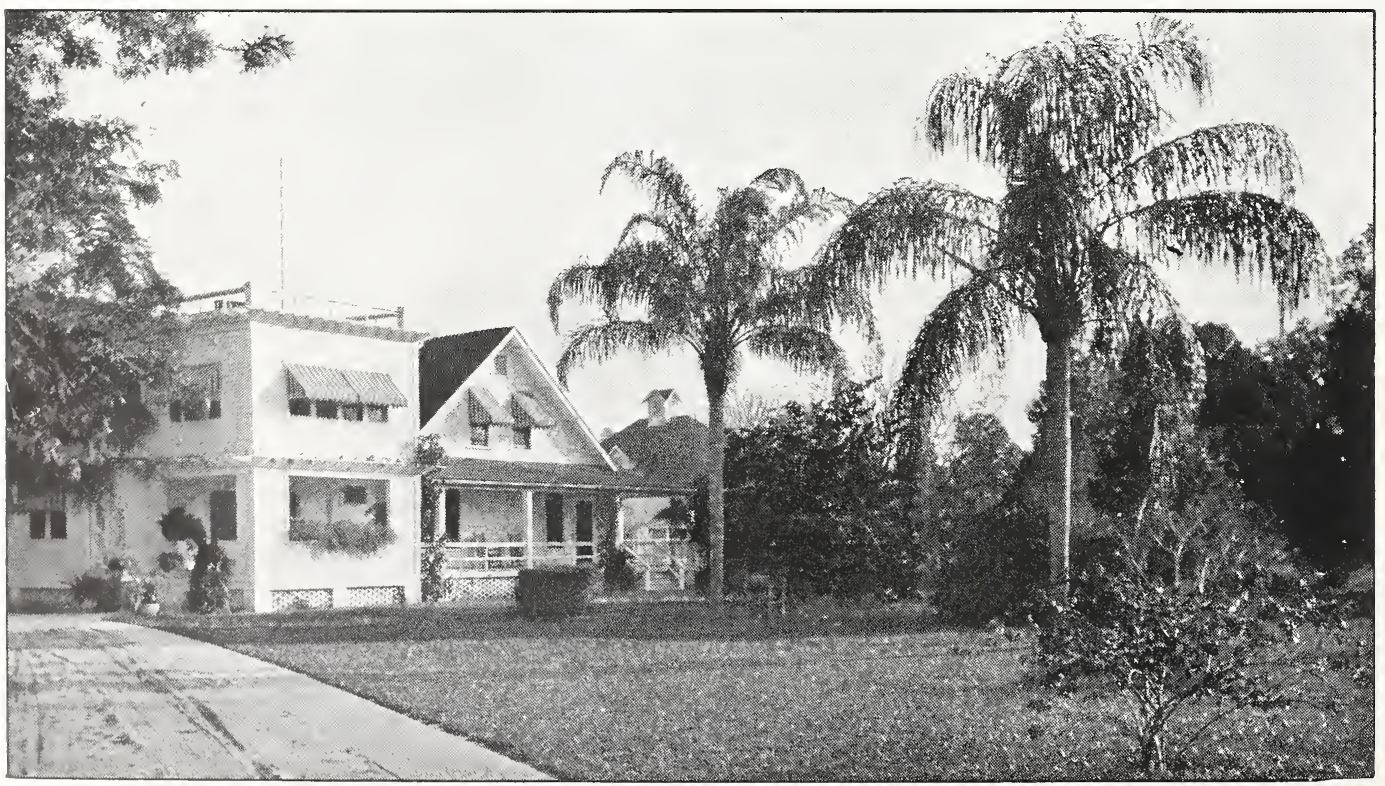

Specimens of Cocos plumosa 


\section{Glen Saint Mary Nurseries Co. Glen Saint Mary, Florida}

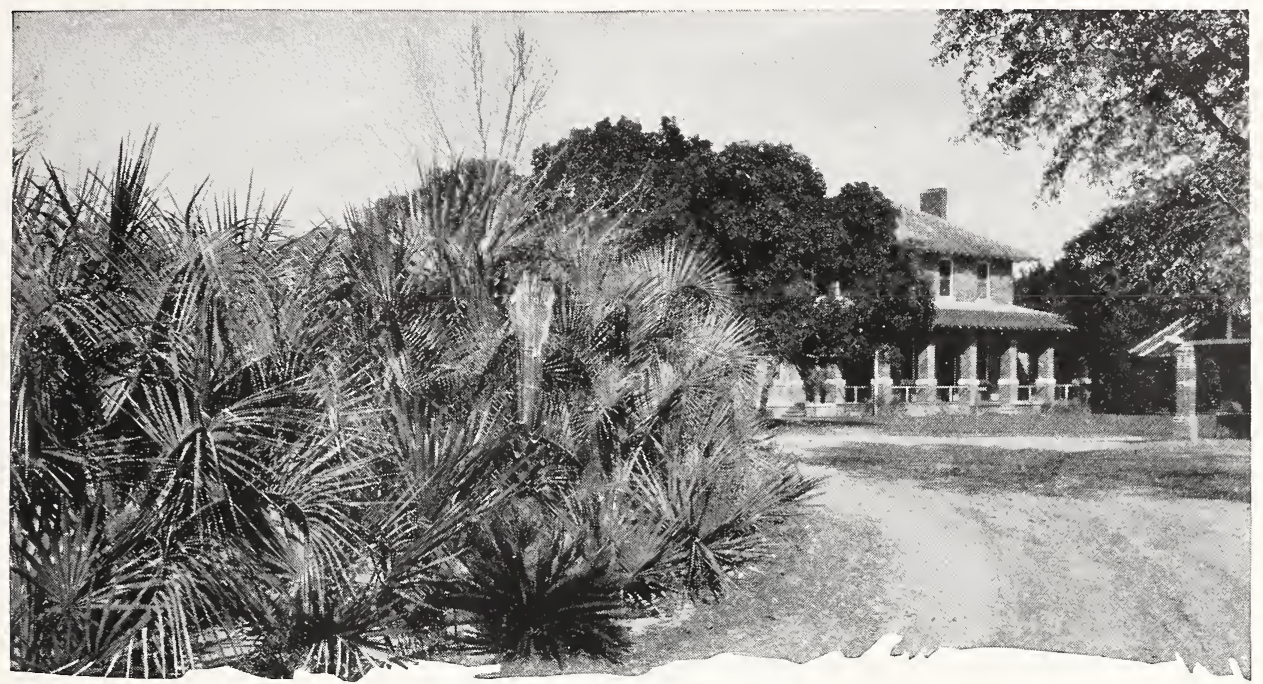

Palm planting and our Office

\section{PALMS, continued}

Phœnix reclinata. A fine $\mathrm{PaIm}$, with slender trunk and beautiful pinnate leaves. Suckers are produced abundantly from the base, and if allowed to grow, develop into splendid clumps. WeIl adapted to south Florida.

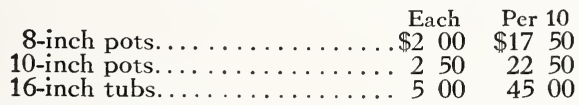

Roebelini. This low-growing PaIm, with its small gracefully curved leaves, is one of the most beautiful of the Phœenix group. It is moderately hardy when planted in the open in southern Florida and is one of the most satisfactory house, porch, and greenhouse Palms.

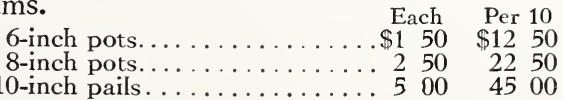

sylvestris. A tall, hardy, rapid-growing PaIm which equals or surpasses Pbœnix canariensis in beauty and hardiness. The leaves are large, grayish green in color.

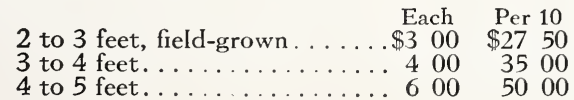

RHAPIDOPHYLLUM hystrix (Needle PaIm). Native to the southern United States from South Carolina to Florida, but rarely seen in cultivation. The trunk is short, 2 to 3 feet, covered with fibre in which are set numerous upright spines. The leaves are borne on long petioles, dark shiny green, under surface pale gray. Very hardy and beautiful when planted in clumps.

Small size Each

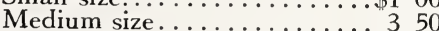

Large size................ 500

Extra size................... 800

Per 10 $\$ 900$ 3000 4500 6000
SABAL Palmetto. The beautiful, hardy native PaIm of the South, commonly called "Cabbage PaImetto." Succeeds in the whole region bordering on the GuIf and along the Atlantic as far north as Cape Hatteras.

\begin{tabular}{|c|c|}
\hline 3 feet. & $\begin{array}{r}\text { Fach } \\
. \$ 300 \\
.400 \\
.500 \\
.800\end{array}$ \\
\hline
\end{tabular}

WASHINGTONIA robusta. A splendid PaIm with dark green fan-shaped leaves; hardy, weII adapted to Florida and the Gulf of Mexico country. It is a rapid grower and reaches a height of from 50 to 80 feet. One of the finest for landscape plantings.

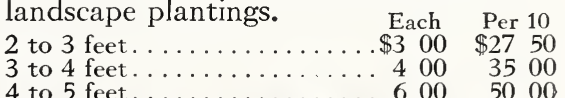

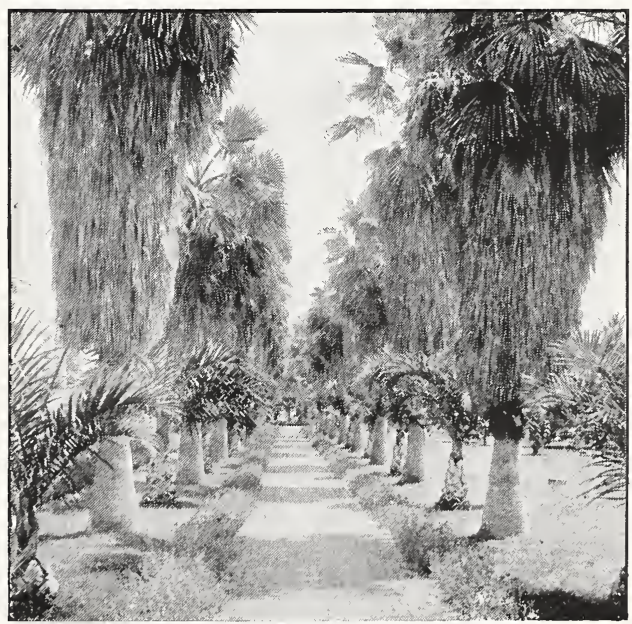

Avenue of Washingtonia robusta 


\section{SOUTHERN PLANTING FACTS}

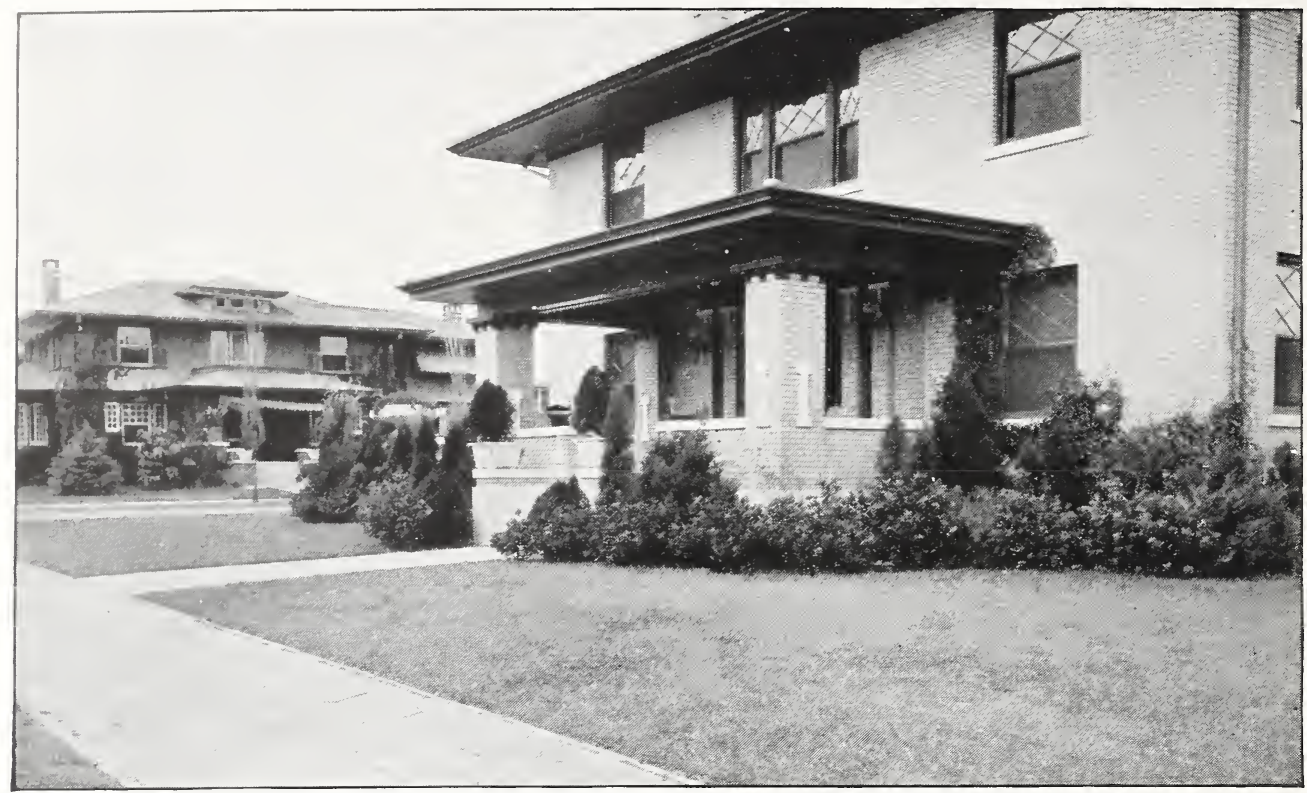

This foundation planting adds greatly to the beauty of the grounds

\section{Coniferous Evergreens}

T THESE plants make beautiful individual Iawn specimens. The different colors-yellow, green, dark green and blue-green-give a striking effect when planted in masses, either when groups are made up of a single kind or of a number of different kinds. They make an excellent background for other shrubs and are of great value in foundation plantings. For hedges they are unsurpassed. In planting for a hedge, they should be given more distance than other hedge plants; 4 to 5 feet apart is not too much. As plants for porches or porch steps, they are very satisfactory. They are hardy and long lived. The conifers grown at Glen Saint Mary and offered to our customers have been tested out for many years, and the list embraces the finest material for southern planting.

While the coniferous evergreens belong to a number of different genera, the following three contain many of the most important and beautiful varieties suited to southern gardens.

Arborvitæ. These are classified as Thuyas by botanists and are also listed as Biotas in some nursery catalogues. Most of those used in the South belong to the species, Thuya orientalis, native in China and Korea. They are beautiful shrubs of compact, symmetrical growth, especially suited for formal gardening when used alone, or for mass and foundation plantings when combined with other shrubs. The Thuyas are hardy and thrive on any moderately good soil.

Junipers. This group of conifers is represented in southern gardens by many beautiful varieties. They are particularly well adapted to soil and climatic conditions and are always dependable.

Retinosporas. Botanists know these by the generic name Chamæcyparis. Those commonly found in southern gardens are mostly varieties of $C$. pisifera, a native of Japan. Their forms are many and varied and in leaf colorings there are many shades. A number of lovely varieties are adapted to southern conditions.

\section{GROUP I}

This includes a number of the most beautiful conifers, some slow-growing and others of dwarf habit:

ARBORVIT $Æ$ aurea conspicua. Deep yellow to golden color, often varying to green. TaIl, compact, and upright. Sizes up to 8 feet.

aurea nana. Compact, rounded head and handsome, greenish golden foliage. Sizes up to 4 feet.

Bonita. This is a beautiful rich green variety, dwarf or of slow growth. It is cone-shaped and rather broad. Sizes up to $2 \frac{1}{2}$ feet.
Arborvitæ compacta. A fine, dark green variety of compact, conical growth. Sizes up to 3 feet.

globosa. A dense, dwarf, dark green form of Occidentalis Arborvitæ that grows like a round ball. It is a good plant for setting in front of other evergreens, for making a low hedge, or for tub or pot specimens. Sizes up to 18 inches. 


\section{CONIFEROUS EVERGREENS - GROUP I, continued}

Arborvitæ Meldensis. A compact, rounded Biota of symmetrical habit and quite distinct color. A slow grower, and one of the finest in the group. Sizes up to 4 feet.

stricta. A very narrow, upright variety with dark green foliage. Very excellent sort where a narrow plant is desired. Sizes up to 3 feet.

CHINESE JUNIPER, chinensis Pfitzeriana (Pfitzer's Juniper). This Juniper forms a low, flat, wide-spreading, irregular head, clothed with bluish green foliage. It is one of the most interesting and beautiful conifers.

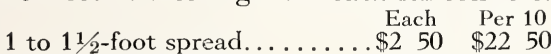

$11 / 2$ to 2 -foot spread........... 3 00 $27 \quad 50$

JAPANESE JUNIPERS, japonica variegata. This very beautiful form of the Chinese or Japanese Juniper is a compact shrub in which the tips of many of the branchlets are creamy white. Sizes up to $31 / 2$ feet.

japonica sylvestris. This is a very beautiful Juniper that grows weIl in the Lower South. The needle-shaped leaves are steel-color, while the smaller, scale-like leaves are dark green. It is narrow and upright in habit. WeIl adapted to conditions in the Lower South. Sizes up to 6 feet.

GREEK JUNIPER, excelsa stricta. A dwarf, narrow, compact, upright Juniper that does weIl under widely different conditions. Its grayish green color is very pleasing. Fine for foundation work. Sizes up to $31 / 2$ feet.

RETINOSPORA ericoides. This is a beautifuI conifer, dense and compact in growth. Naturally it is an upright grower and may be pruned in very narrow, columnar shape. The foliage is a dark bluish green. Not particular as to soil. Sizes up to 5 feet.

filifera. This very hardy variety has slender, pendulous branches and light green leaves. It is one of the most decorative of all conifers, of medium height. Sizes up to 4 feet.

pisifera argentea. A dwarf, compact variety. Branches silver-tipped. Sizes up to 2 feet. pisifera aurea. A showy evergreen of dense growth; new shoots of a rich golden color. Dwarf. Sizes up to 2 feet.

Prices on Group I, except Pfitzer's Juniper. Each Per 10

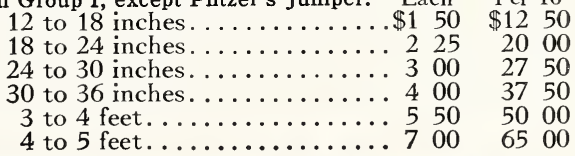

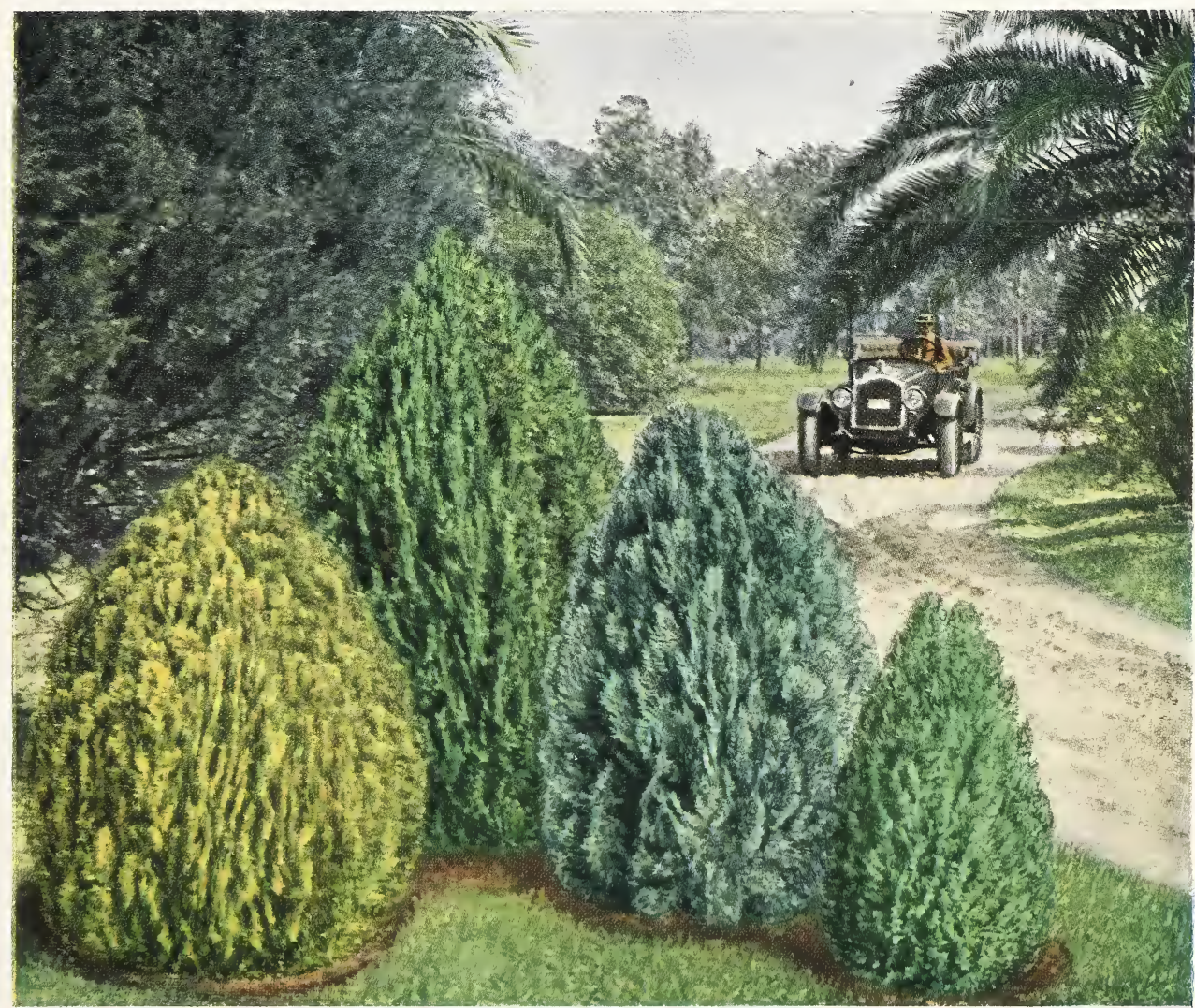

Arborvitæ aurea nana

Arborvitæ pyramidalis 


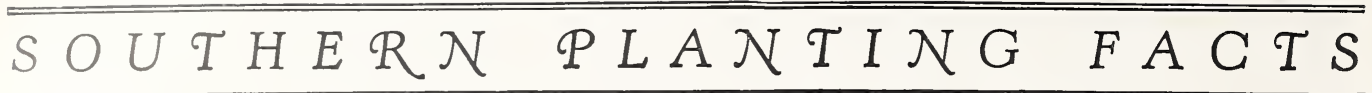

\section{CONIFEROUS EVERGREENS-GROUP II}

Including Iarger and more rapid-growing varieties of Arborvitæ, Junipers, and Retinosporas:

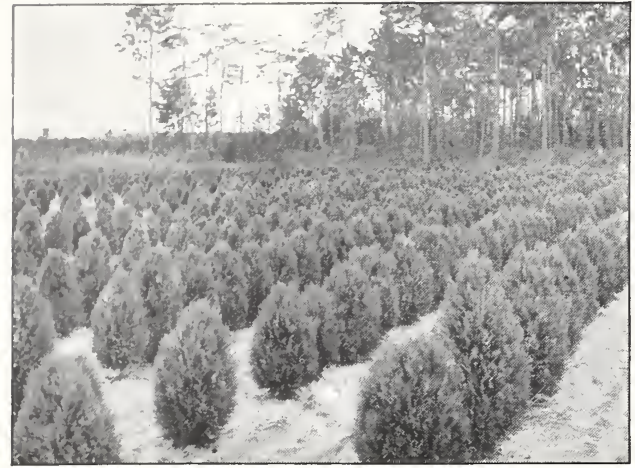

View in Arborvitæ Nursery

ARBORVIT $Æ$, Blue-Green. This is a handsome Arborvitæ with bluish green foliage that does not change color in winter. A strong grower and soon makes fine, large, beautiful specimens which retain their good appearance, even when old. Sizes up to 4 feet.

Rosedale. Of compact, rounded, symmetrical form, with very dense head. The foliage is dark, bluish green and very handsome. Sizes up to $31 / 2$ feet.
Arborvitæ pyramidalis. A compact, pyramidal Arborvitæ, reaching a height of about 15 feet. Bright green, and holds its color well. Very fine. Sizes up to 6 feet.

JUNIPERUS communis. A fine variety; spreading branches and green foliage. Sizes up to 4 feet.

communis oblonga. This variety is dark green, upright in form, with slender, recurving branches. Can be pruned in any desired shape. Sizes up to 4 feet.

RETINOSPORA squarrosa sieboldi. A rather dwarf, compact conifer, with bluish green leaves that take on a purplish tint in cold weather. It is an attractive and noteworthy variety. Sizes up to 3 feet.

squarrosa veitchi. A rapid-growing variety with silvery blue foliage. It is a handsome, distinct conifer, reaching a height of 13 to 20 feet, and shears well. Sizes up to 4 feet.
Prices on Group II.
Each Per 10
1 to $11 / 2$ feet..............\$1 25 $\$ 1000$

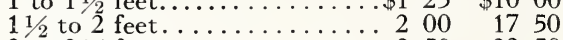
2 to $21 / 2$ feet................... $250 \quad 2250$
$21 / 2$ to 3 feet.............................. 253000
3 to 4 feet................. $425 \quad 4000$
4 to 5 feet................. $550 \quad 5000$
5 to 6 feet.... 7507000

\section{GROUP III}

Miscellaneous conifers. A selected group of kinds weIl adapted to southern conditions.

ARAUCARIA Bidwilli. The Bunya-bunya is a handsome tree from youth to old age. It reaches a height of upwards of 150 feet. The branches are borne in whorls and clothed with large, firm, shiny, sharp-pointed leaves. Well-grown specimens always attract attention because of their glossy green color and symmetrical habit. It is one of the most beautiful of the Iarger-growing conifers. Adapted from middle Florida southward, though occasionally met with farther north. Prices of Pot-Grown Plants.

18 to 24 inches. . . . . . . . . . . . . . . . . $\$ 350$

24 to 30 inches.......................... 500

CEDRUS Deodara (Indian Cedar). Of pyramidal form, reaching large size. Foliage a beautiful shade of bluish green. When the new foliage is opening in spring, the trees are particularly handsome. This tree is well adapted to the Southern States. It takes the place of Colorado Blue Spruce in southern plantings, is more open and graceful in habit, but similar in coloring. It should be planted only on well-drained soils, as it may be killed by too much water.

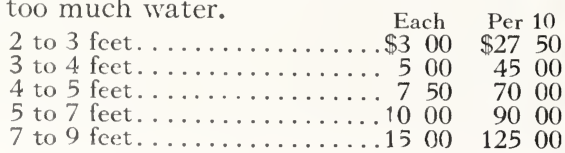

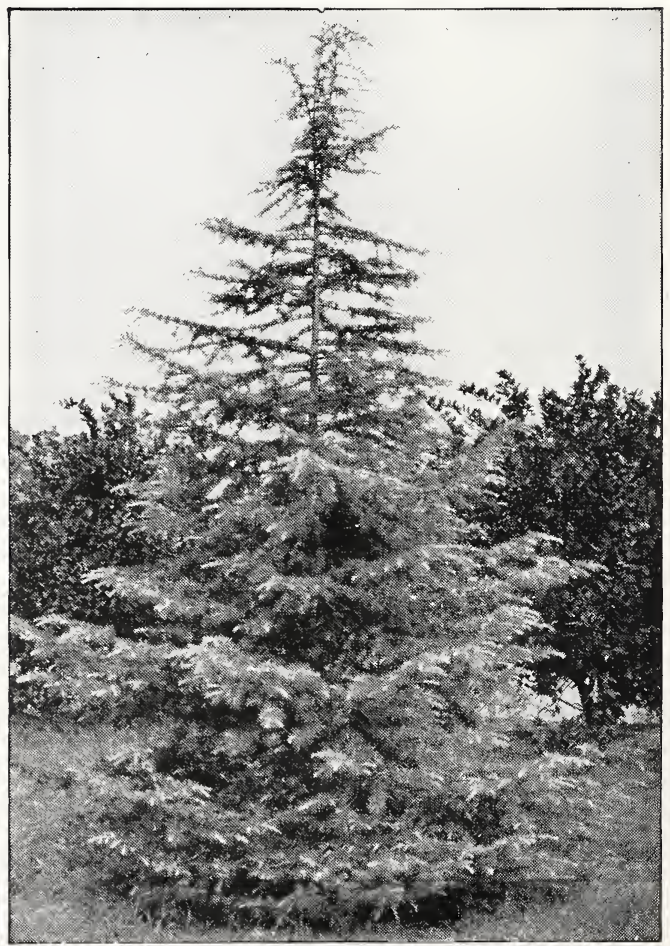

Cedrus Deodara 


\section{Glen Saint Mary Nurseries Co. Glen Saint Mary, Florida}

\section{CONIFEROUS EVERGREENS-GROUP III, continued}

CRYPTOMERIA japonica. A Japanese tree with slender trunk and straight, spreading branches that turn upward at their tips. It is graceful in habit and rapid in growth. Grows best on good, heavy soil.

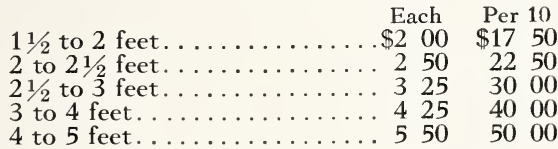

JUNIPERUS sabina cupressifolia (Creeping Juniper). A Juniper of trailing or creeping habit; bluish green; very handsome. Excellent for bordering walks, for planting on sloping ground, or for use as a ground-cover.

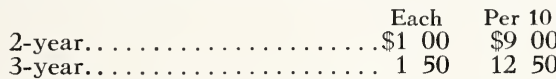

virginiana. The Red Cedar is a tree with a dark green head and spreading or upright branches. It grows rapidly and is adapted to a wide range of soils. It does well either in full sun or in partial shade, and is one of the most dependable of all the conifers.

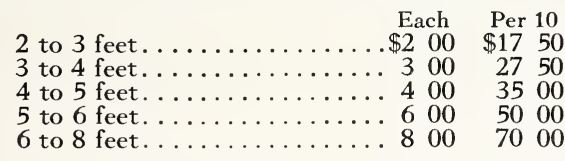

PINUS caribæa (Slash Pine). One of the handsomest species of our native Pines. Desirable as single specimens or for use in landscape plantings. Furnished from pots only, as open-ground plants are difficult to transplant.

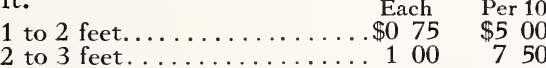

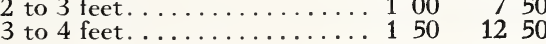

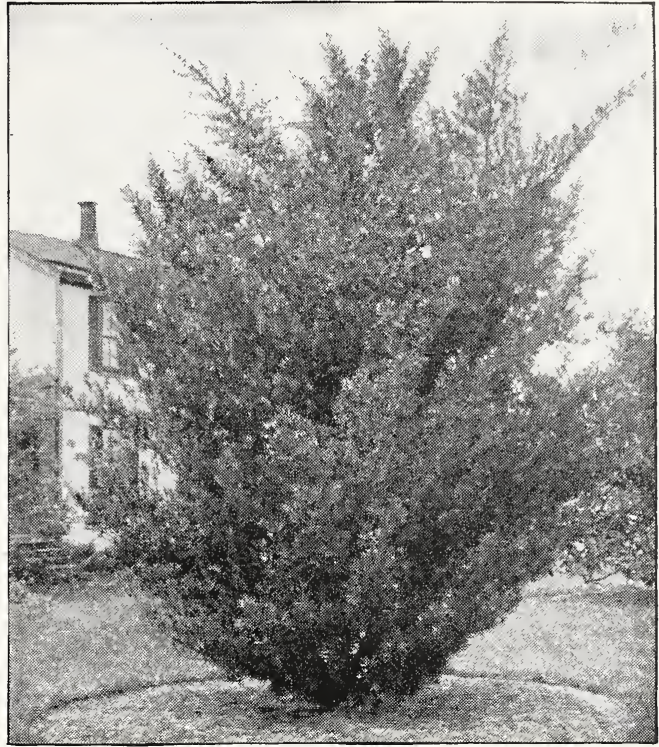

Podocarpus

PODOCARPUS macrophylla Maki. Heretofore catalogued as Cephalotaxus. A beautiful evergreen, upright, branching shrub or small tree with rather broad leaves, light green when young, dark green when mature. It is an excellent plant for hedges, screens, specimens, or for the shrubbery border. Hardy.

\begin{tabular}{|c|c|}
\hline $\begin{array}{l}\text { y. } \\
\text { to } 11 / 2 \text { feet. } \\
1 / 2 \text { to } 2 \text { feet. } \\
\text { to } 3 \text { feet. }\end{array}$ & 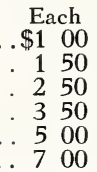 \\
\hline
\end{tabular}

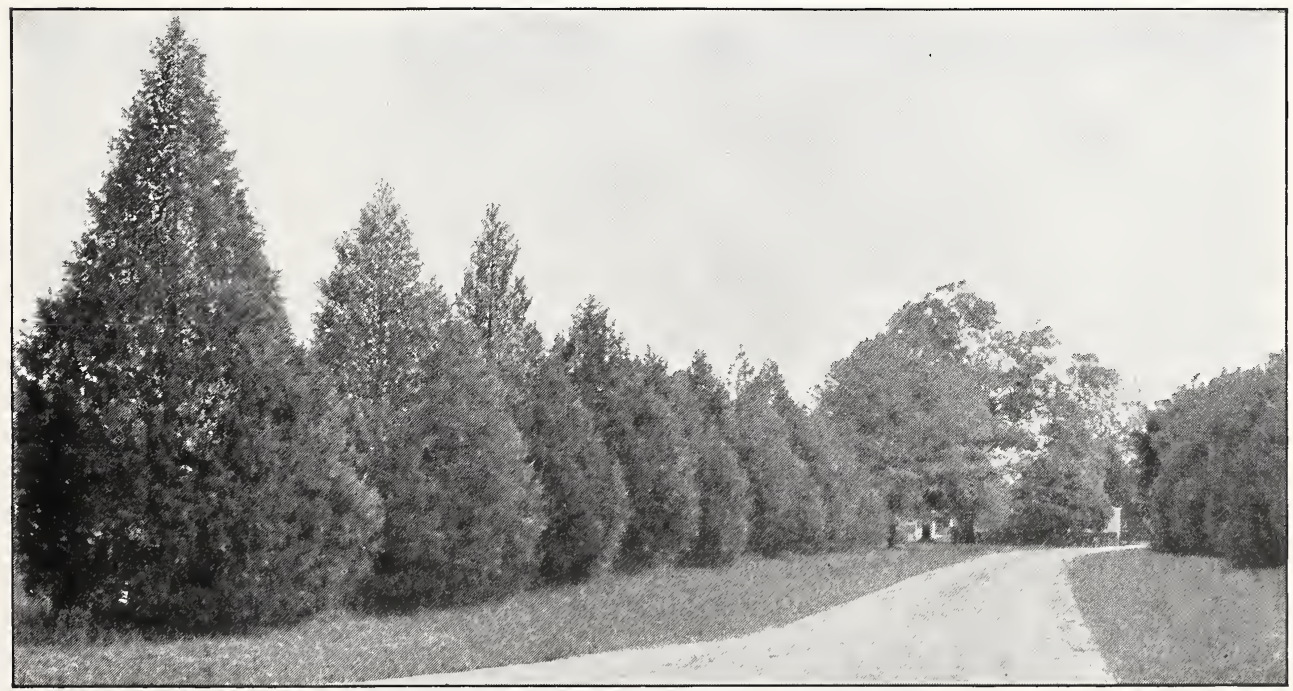

Roadway planted with Juniperus virginiana 


\section{SOUTHERN PLANTING FACTS}

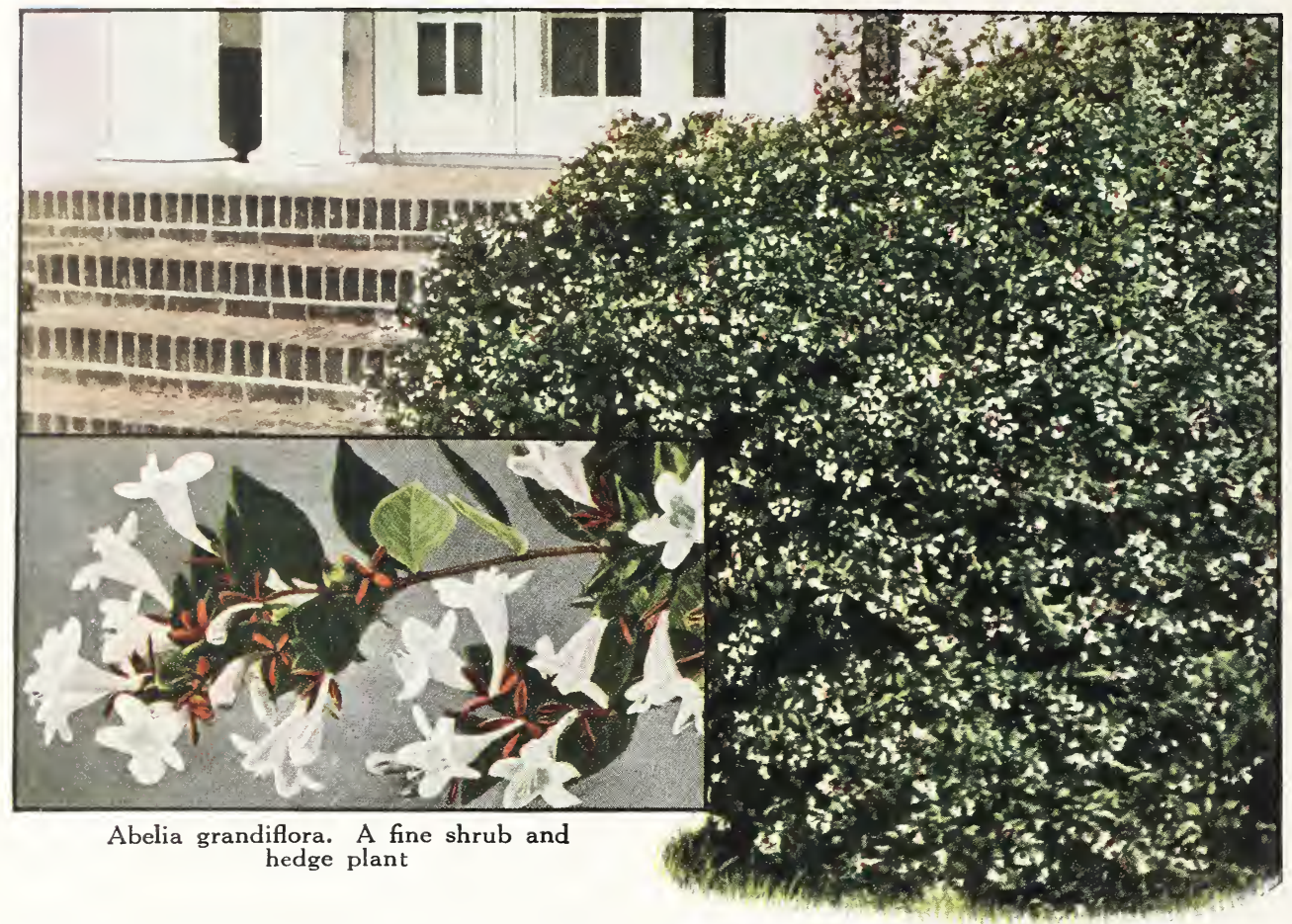

\section{Shrubs and Hedge Plants}

TOTHING adds so much to the beauty of the home surroundings, nothing gives so much pleasure, 1 as a good lawn and weIl-placed shrubs and vines. It is seldom indeed that a home in the country, grounds; and for this purpose both evergreen and flowering shrubs lend themselves admirably. Shrubbery is most effective in bringing out certain features of the lawn and softening harsh lines, to screen some unsightly building or object or to break the outline of foundation walls. The number which may be planted will be governed by the shape and extent of the grounds; but even the smallest lot has a place for a few. They should be planted in masses, in corners about the buildings, always leaving a goodly proportion of open Iawn. The plants to be used will depend upon climate, location, character of soil, exposure, and the size and architecture of the building. Aside from their value in beautifying the grounds, they actually increase the money-value of a property. A city lot, for instance, with well-grown shade trees and shrubs, is decidedly more valuable and more easily disposed of, when offered for sale, than a piece of bare ground.

ABELIA grandiflora. The most satisfactory addition to the list of hedge plants in years. Can be pruned flat or rounded on top. Planted singly or in groups, will add a touch of beauty to the lawn all the year round. It is an evergreen shrub with glossy, dark green foliage. In winter when affected by cold the leaves turn a beautiful shade of bronze and look as though coated with varnish. The flowers are white, funnel shaped, tinted with pink, delicately sweet scented and borne in clusters from May until late in autumn.

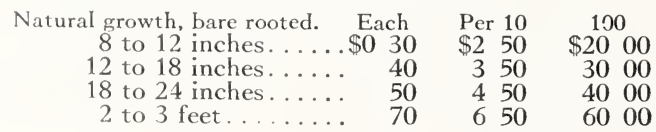

Shapely plants, spade-balled. Each Per $10=100$ 12 to 18 inches..... $\$ 075 \quad \$ 700 \quad \$ 6000$ 18 to 24 inches...... $100 \quad 900 \quad 8000$ 2 to 3 feet......... $150 \quad 1400 \quad 13000$

Specimens, spade-balled.

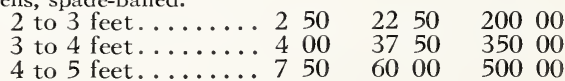

ACACIA longifolia. Evergreen, densely branched and foliaged, willowy. Leaves long, narrow, dark green; flowers golden yellow in February and March. This is one of the very few Acacias suited to Florida conditions. Desirable for planting from middle Florida southward.

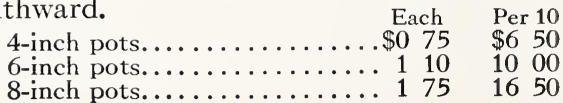




\section{Glen Saint Mary Nurseries Co. Glen Saint Mary, Florida}

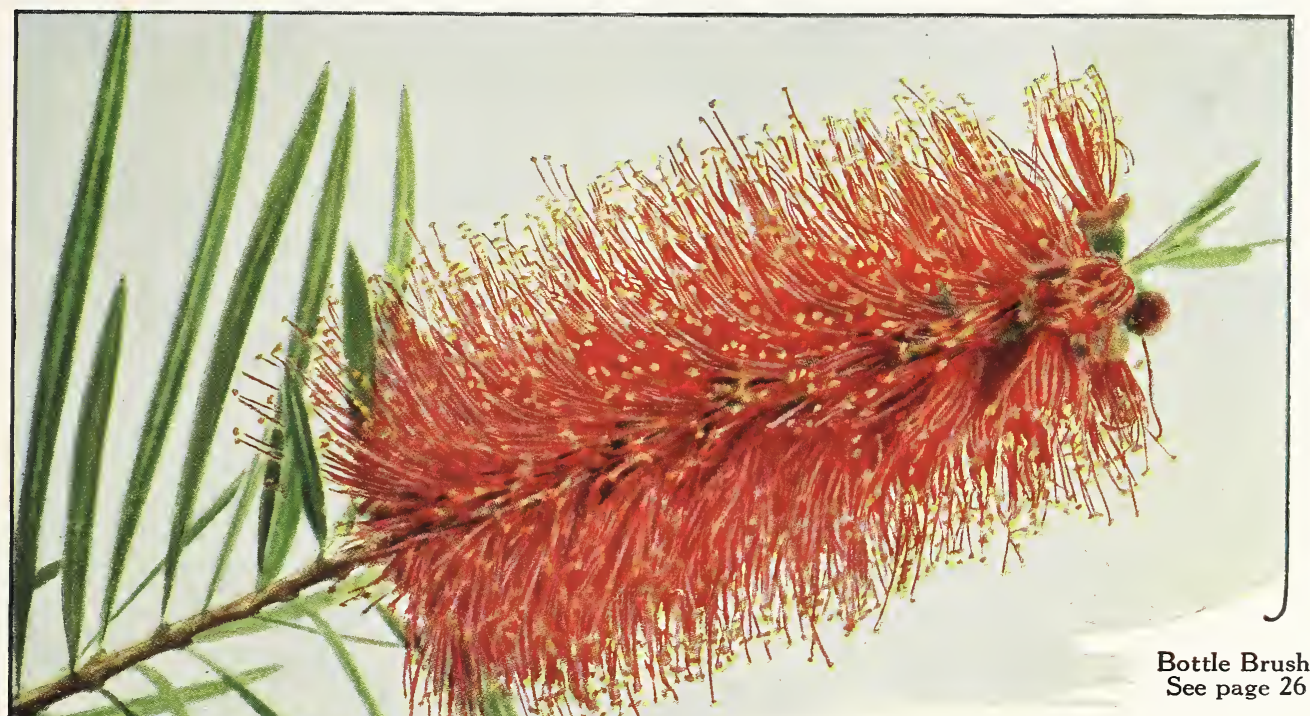

ARDISIA crenulata. A compact evergreen shrub with thick, dark green foliage and bright red berries which color during the late fall and persist through the winter. Fine for shade and half-shade. Reaches a height of about $21 / 2$ feet and is a slow grower.

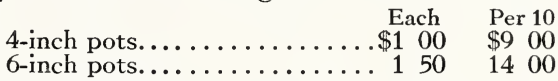

striking plants for use in the warmer parts of Florida where they are planted in the shrubbery border for specimens and for hedges.

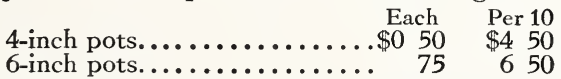

AUCUBA japonica. This shrub, with its stout, round, green branches and rich, dark green, coarsely toothed leaves is so hardy that it may be grown in the open as far north as Washington, D. C. It is one of the best shrubs for shady locations. Since it is a slow grower it should have a rich, moist, welldrained soil for satisfactory results.

japonica aureo-maculata. In this variety of Aucuba, sometimes known as the Gold-Dust Tree, the leaves are dotted and splashed with yellow markings. Very satisfactory as an accent shrub in the border and for growing in pots and window-boxes.

Prices of both varieties. $\quad$ Each Per 10 4 -inch pots.............\$1 00 \$9 00 6 -inch pots................. $150 \quad 1400$

BACCHARIS halimifolia (Salt Bush). A native evergreen shrub with medium-sized, coarsely toothed leaves and rather upright branches. Fruiting plants produce an abundance of tiny seeds, clothed with pappus that gives the bushes a fluffy white appearance in autumn. It reaches a height of 8 to 10 feet, but may be kept at any desired height by pruning. It grows well on poorly drained soils and is most satisfactory for seaside planting, as it will stand ocean wind and salt spray without injury.

Each Per 10

Small plants............\$0 50 \$450




\section{SIHRUBS AND HEDGE PLANTS, continued}

BERBERIS sargentiana (Sargent's Barberry). An evergreen shrub with narrow-toothed, spiny leaves that on the new shoots are several different shades of green. This is a valuable shrub, reaching a height when full grown of about 6 feet.

6-inch pots.

Each Per 10

$\$ 1 \quad 10 \quad \$ 1000$

BOTTLE BRUSH. A beautiful shrub, of rather slow growth, but finally reaching a height of about 15 feet. The leaves are narrow, pointed, dark green, and the flowers are bright red, in cylindrical brush-like spikes. They open in spring and continue in bloom for several weeks. The button-like seed-pods adhere to the branches for several years. Hardy from northern Florida southward and along the Atlantic coast farther north.

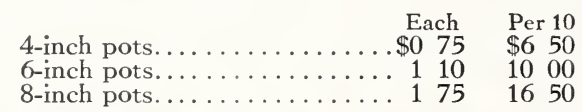

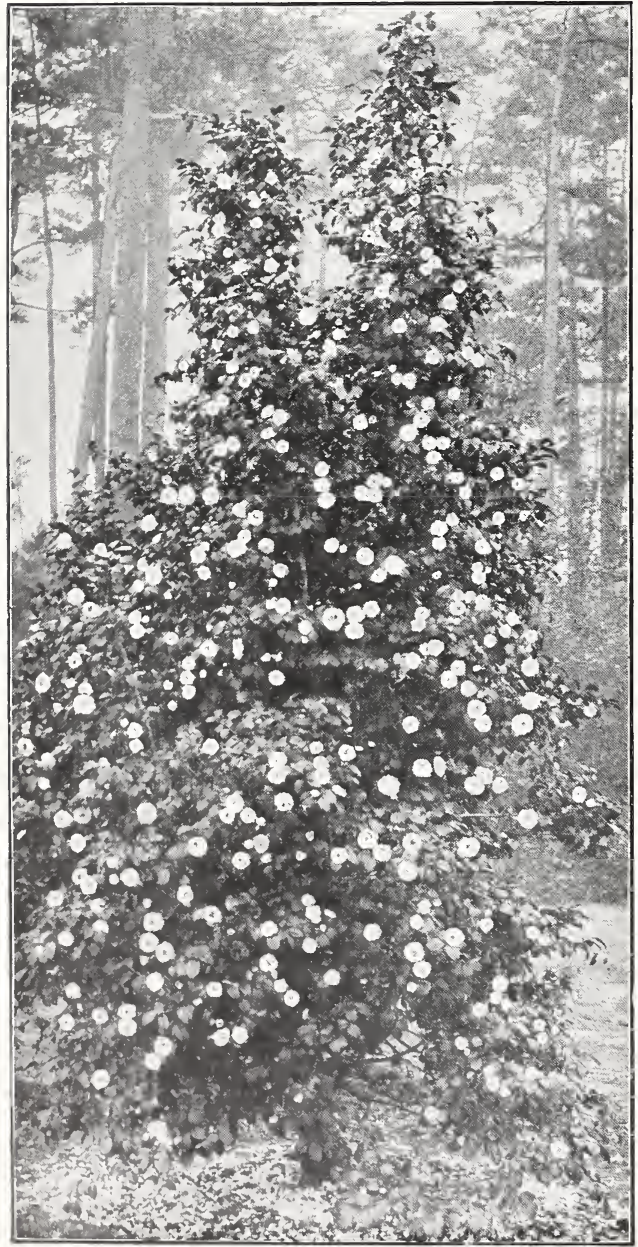

Camellia japonica
BUDDLEIA. Important evergreen shrub of recent introduction. The flowers are produced in terminal racemes and somewhat resemble lilacs in general appearance. During the summer they remain constantly in bloom and attract butterflies in great numbers. A well-grown bed of Buddleias with butterflies of many different colors flitting over them is a unique and pleasing sight. Excellent for cut-flowers. Each Per 10

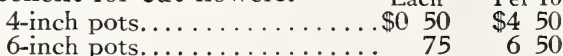

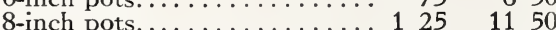

asiatica. A rapid-growing, winter-flowering evergreen shrub with Iong spikes of smaIl white delicately scented flowers and Iarge pointed leaves.

Eva Dudley. This hybrid variety flowers freely both summer and winter, unless its growth is checked by cold. Flowers lavenderpink with orange centers; fragrant.

officinalis. A strong-growing shrub with delicate Iilac-pink flowers in terminal racemes. Blooms during winter. Very fine.

CAMELLIA japonica. The Japonica of the South. A well-known shrub, with glossy green foliage and beautiful flowers. Dense and symmetrical in its growth. Winter blooming. The colors are white, pink, red, and variegated.

Pot-grown.

8 to 12 inches..........\$1 00 \$9 00

12 to 18 inches............... $150 \quad 1400$

18 to 24 inches............ $250 \quad 2250$

Seedling Plants. These make very useful plants for the evergreen border and generally the flowers produced, most of them single, are very satisfactory. Adapted to the South.

sasanqua. A small-leaved, rather openIy branched evergreen shrub, related to the weIl-known Japonica. The flowers are single, white or pink, about 3 inches across, with a cluster of yellow stamens in the center. It flowers in early autumn when few shrubs are in bloom. A slow grower, but reaches a height of 6 to 8 feet. Seedlings only.

Prices of Camellia sasanqua and Seedlings.

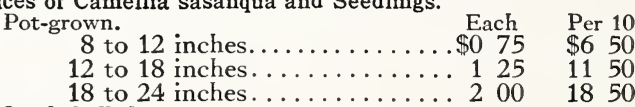

Spade-balled.

3 to 4 feet. .............. 500

4 to 5 feet.............. 800

CESTRUM nocturnum. A shrub 6 to 9 feet high, adapted to south Florida; branches willowy, curved, producing creamy yellow flowers, fragrant at night. Each Per 10

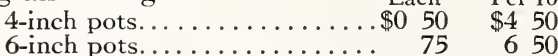

CLEYERA japonica. A fine evergreen shrub with rather thick, glossy leaves and creamy white, fragrant flowers. Berries red in winter. An upright grower, reaching a height of 10 to 12 feet.

Each

4 -inch pots...........\$0 75

Per 10 1000 


\section{Glen Saint Plary Nurseries Co. Glen Saint Plary, Florida}

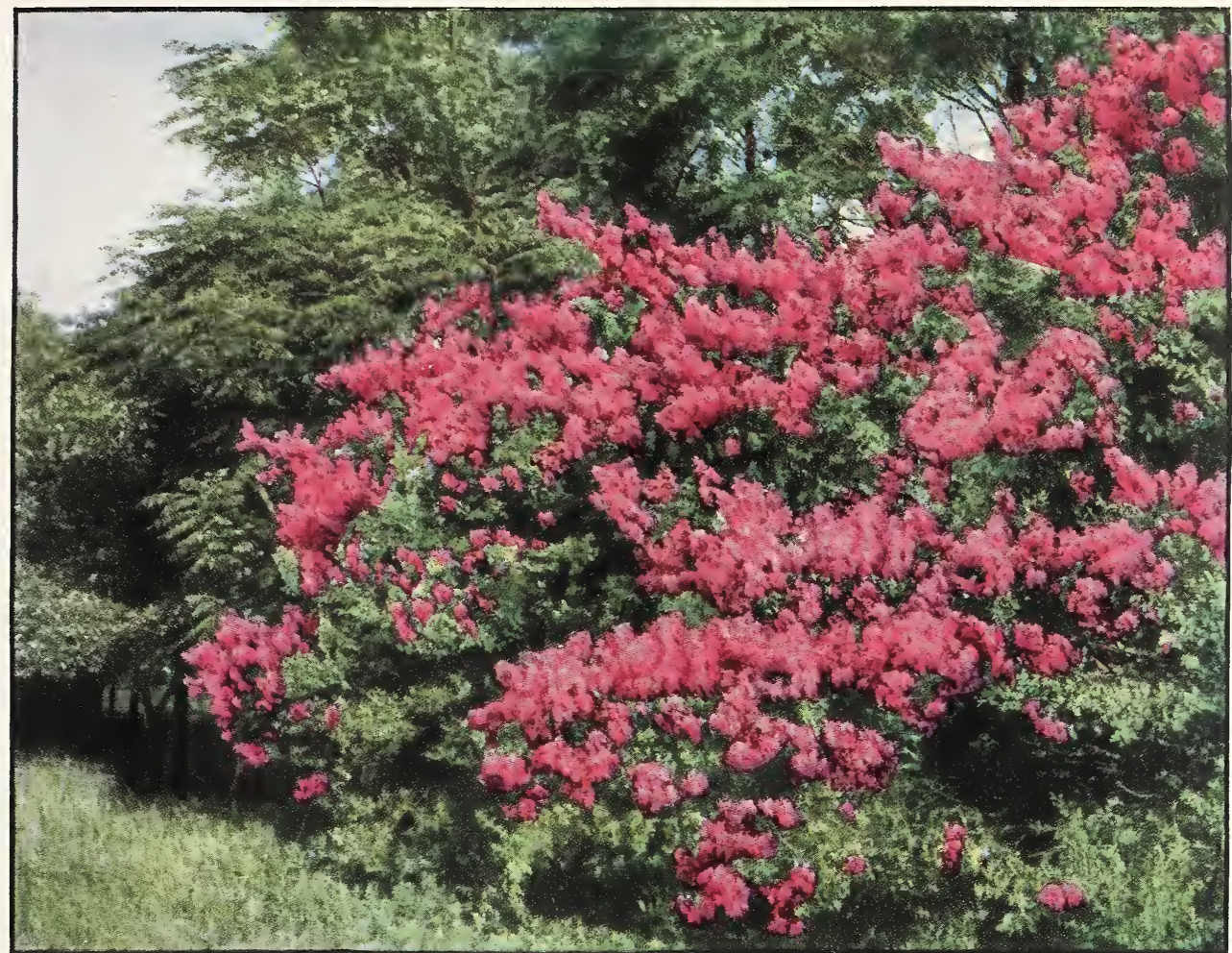

Crape Myrtle

SHRUBS AND HEDGE PLANTS, continued

COTONEASTER pannosa. A beautifuI, hardy shrub, evergreen in the South. Leaves small, silvery beneath, green above. Flowers white, followed by red fruits. Each Per 10

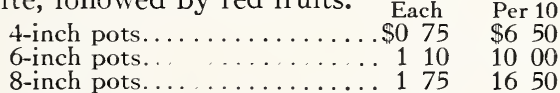

CRAPE MYRTLE (Lagerstræmia indica). Vigorous, deciduous shrubs or small trees, reaching a height of 15 to 20 feet. The leaves are smaIl, bright green and glossy. The flowers, which appear in spring, are fringed and colored in different shades of white, purple, and scarlet. The trees, when in blossom, are covered with large panicles of bloom and remain in flower for several weeks. Hardy, easily grown, and succeed on different soils.

\begin{tabular}{|c|c|c|c|}
\hline $\begin{array}{r}\text { Prices of all varieties. } \\
2 \text { to } 3 \text { feet. } \\
3 \text { to } 5 \text { feet.. } \\
5 \text { to } 7 \text { feet. }\end{array}$ & $\begin{array}{rl}\text { Each } \\
. \$ 050 \\
. \quad 75 \\
1 & 25\end{array}$ & $\begin{array}{rr}\text { Per } & 10 \\
\$ 4 & 50 \\
6 & 50 \\
10 & 00\end{array}$ & $\begin{aligned} & 100 \\
& \$ 4000 \\
& 5500 \\
& 9000\end{aligned}$ \\
\hline
\end{tabular}

Purple. A grand sort, producing immense clusters of flowers of rich purple.

Rose. A very free-flowering old-rose Crape Myrtle. A valuable addition to our list.

Scarlet. Of handsome growth; a bright, showy plant with large bunches of scarlet flowers.

White. A pure white form with large clusters of flowers; very free blooming and a showy shrub in any landscape.
CUPHEA hyssopifolia. A dwarf shrub with pale Iilac flowers and smaIl leaves borne on slender twigs. As it is very compact in growth and may be pruned to shape, it can be used as a bedding plant, for edging plantings of larger shrubs, and for carpet bedding. Cuphea is easily grown and does weIl on light, sandy soils. It succeeds best in full sunshine.

$$
\begin{aligned}
& \text { 4-inch pots. ........................ Per } 10 \\
& 6 \text {-inch pots................ } 75 \quad 650
\end{aligned}
$$

DURANTA plumieri (Golden Dewdrop). An evergreen shrub with dark green leaves and racemes of light blue flowers, followed by yellow berries that hang on throughout the winter. It is rather tender but is planted as far north as northern Florida. It is sometimes frozen down in winter but grows out rapidly from the crown and soon flowers and fruits again. In southern Florida it makes a large-sized, beautiful shrub. The combination of golden fruit and sky-blue flowers makes this one of the most beautiful shrubs.

plumieri alba (White-flowered Golden Dewdrop). This variety is identical with the one above, except that its flowers are white instead of blue.

Prices of both varieties.

4 -inch pots............ $\$ 050 \quad \$ 450$

6 -inch pots................ $75 \quad 60$ 


\section{SHRUBS AND HEDGE PLANTS, continued}

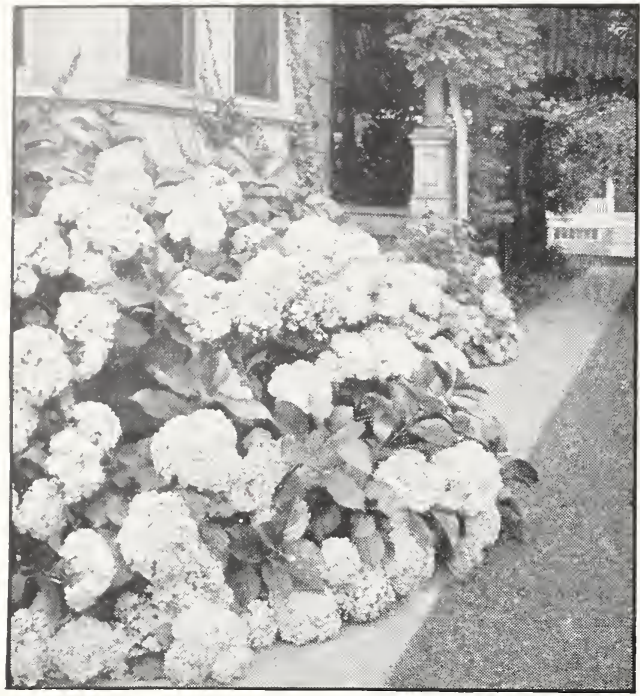

Hydrangea

ELÆAGNUS pungens. A spreading evergreen shrub reaching a height of 6 feet; leaves dark green above, silvery beneath. Delights in a bright, sunny location and is adapted to a wide range of conditions.

pungens variegata. A very desirable variegated form with light green leaves edged with yellowish white. Prices of both varieties.
4 -inch pots............. Each

6-inch pots................ $110 \quad 1000$

FEIJOA Sellowiana. A hardy, compact evergreen shrub with dark green foliage, grayish beneath, and purplish flowers. It is closely related to the guavas and is a valuable addition to our list of shrubs. Each Per 10 8 -inch pots ............. $\$ 125 \quad \$ 1150$ Field-grown, spade-bailed.

12 to 18 inches............ $150 \quad 1250$

18 to 24 inches................. $200 \quad 1750$

HIBISCUS rosa-sinensis. Showy evergreen shrubs with glossy leaves and large, brightcolored flowers 4 to 5 inches across. They are amongst the most gorgeous and satisfactory shrubs that may be grown out-ofdoors in south Florida, or under glass in the North. Under suitable conditions they bloom almost continuously, and the large bright flowers are very striking.

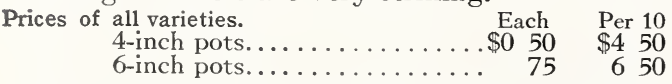

Double Pink. Flowers very large, rich pink in color. One of the handsomest.

Giganteus. Single flowers of immense size, vivid crimson-scarlet in color.

Grandiflora. Flowers single, very Iarge, beautiful shade of pink. Very fine.

Peach Blow. Flowers double, light pink with dark centers. A very beautiful and attractive variety.
Hibiscus rosa-sinensis, continued

Shell-Pink. A new variety, with beautifuI single shell-pink flowers of medium size.

Single Pink. A single-flowered form with large flowers.

Single Salmon. A good shade of salmonyellow with red center.

Single Scarlet. Similar to the single pink but a deep, dazzling scarlet in color.

Versicolor. Flowers single, scarlet, shaded light yellow, with deep red center.

HYDRANGEA hortensis. A very ornamental group of deciduous shrubs adapted for southern outdoor planting. They make an excellent showing in massed plantings and are weIl adapted to shady and half-shady locations. The white varieties bloom true to color; the others may be either pink or blue, depending on soil and cultural conditions. If blue flowers are desired, grow the plants in an acid muck or peat soil. Pink flowers may be secured by using lime liberally.

Prices of all varieties. $\quad$ Each Per 10

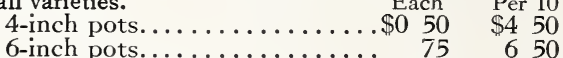

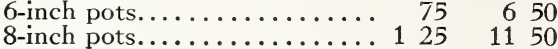

Avalanche. Fine, large, white variety, very beautiful and fine for lawn planting.

E. G. Hill. Flowers either pink or baby blue; flower trusses of immense size; a fine grower and very satisfactory.

General de Vibraye. Blue or pink; vigorous grower; large trusses of large flowers.

Mme. E. Mouillere. Pure white; very free flowering; one of the finest sorts.

Mousseline. Blue with cream-colored center, or pink; strong, upright grower, producing immense clusters of large flowers.

Otaksa. A splendid Hydrangea with bright green foliage and large trusses of blue or pink flowers. It is a strong grower.

ILEX glabra (Inkberry). Much-branched native evergreen shrub, with bright shiny green, roundish leaves; fruit black. WeIl adapted for growing in clumps. Will succeed under very adverse conditions. Splendid for massing in shady locations. Height 3 to 4 feet.

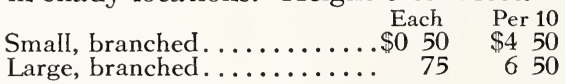

cornuta (Chinese Holly). This shrubby Holly is of slow growth, reaching a height of 6 to 8 feet, and the spreading branches form a thick head. The thick, bright, shiny leaves are tipped with three stout spines at the apex and usually are armed with two on the sides. vomitoria (Yaupon). A native evergreen Holly with smaIl foliage, compact bushy head and bright red berries produced in great profusion. This is one of our most desirable shrubs for foundation, border and hedge planting. Reaches a height of 10 to 12 feet if left unpruned.

For prices of Ilex cornuta and vomitoria, see next page 


\section{Glen Saint Mary Nurseries Co. Glen Saint Mary, Florida}

\section{SHRUBS AND HEDGE PLANTS, continued}

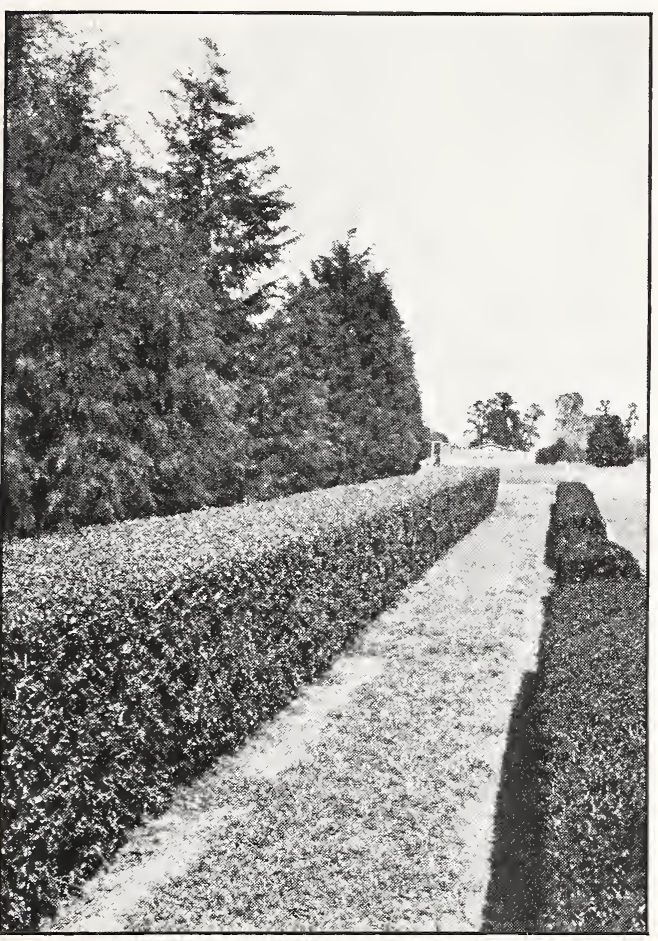

Hedge of Ilex vomitoria. See page 28

Prices of Ilex cornuta and vomitoria. Bare-rooted.

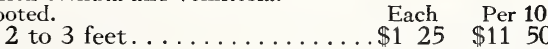

3 to 4 feet.................... 50

4 to 6 feet....................

6 to 8 feet.................. $350 \quad 3000$

Spade-balled.

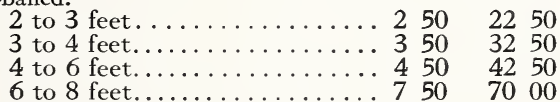

Sheared specimens, $\$ 10$ to $\$ 25$ each.

IXORA cuccinea. An evergreen shrub of spreading habit, with large leaves and orange-red, star-shaped flowers in flat-topped clusters. This is one of the most desirable of the flowering shrubs for southern Florida.

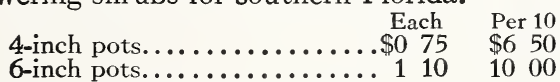

JASMINUM floridum. A hardy shrub with glossy dark green foliage and golden yellow star-shaped flowers a half inch in diameter, opening in spring and summer. A very desirable and valuable species.

humile. A dark evergreen much-branched shrub with compound leaves; flowers bright yellow, borne in clusters. Hardy. A very fine plant.

primulinum. An evergreen shrub with arching branches and dark green leaves; bright yellow flowers produced in early spring. A splendid plant for banks, walls, and fences where its slender branches can hang over.
Prices on three preceding varieties.

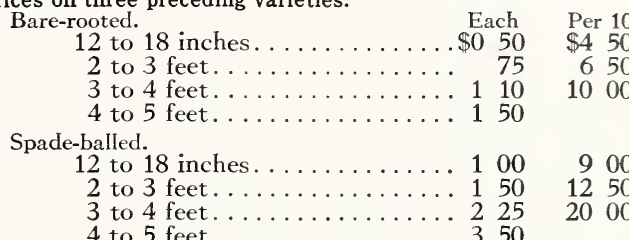

LANTANAS. BeautifuI, showy, easily grown shrubs which may be grown in almost any soil; very free-flowering. Can be furnished in white, yellow, orange, lilac, and red. The weeping Lantana, with deep Iilac flowers, makes a fine ground-cover and is excellent for window-boxes.

4-inch pots............. Each $\quad \stackrel{\text { Per } 10}{\$ 40}$

LIGUSTRUM lucidum. Hardy. A broadleaved evergreen shrub of compact growth, with dark glossy green foliage. In north Florida the white-panicled flowers are produced during May and are followed by black berries. A desirable shrub for planting on the grounds and also for foundation and border planting. Very handsome. It does not appear to be particular about soil conditions, and can usually be planted with assurance of success.

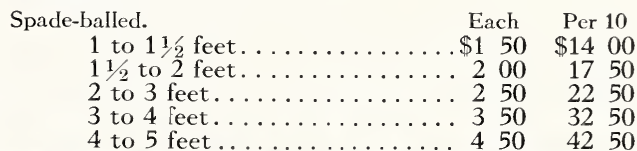

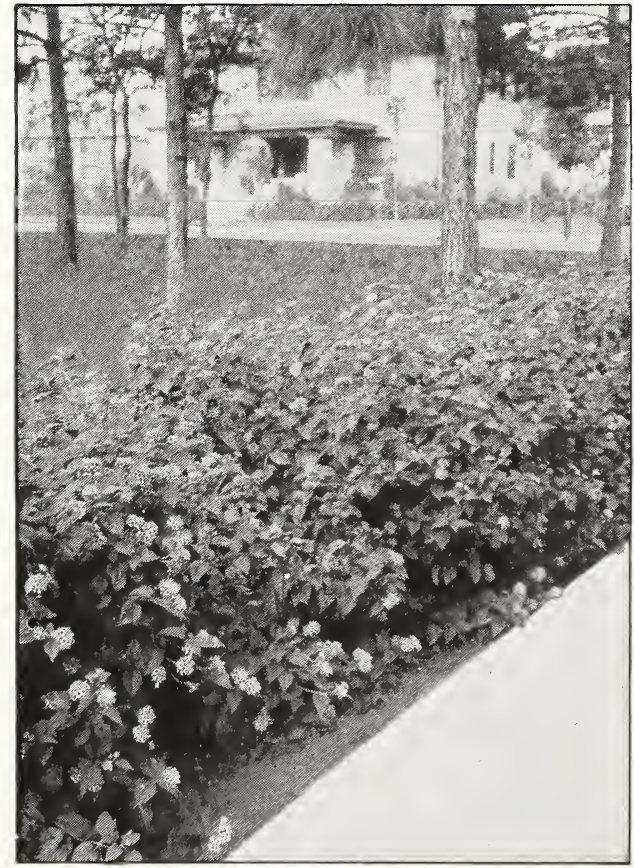

A Lantana Hedge 


\section{Glen Saint Jary Nurseries Co. Glen Saint Mary, Florida}

\section{SHRUBS AND HEDGE PLANTS, continued}

Osmanthus, continued aquifolium. The oval leaves of this variety are spiny, like those of holly, and the flowers are borne in small clusters. It is a very satisfactory shrub.

Fortunei. The leaves are larger than those of aquifolium. It is a very compact grower and a desirable shrub for the grounds.

PHYLLANTHUS. Beautiful shrubs with dark zigzag branches and thin medium-sized leaves. Very beautifuI when grown singly or in clumps. Fine for south Florida.

nivosus roseo-pictus. A handsome shrub with beautiful foliage in various shades of green, white, pink, and red. Each Per 10 4 -inch pots..............\$0 50 \$450 6 -inch pots.............. $75 \quad \begin{array}{r}6 \\ 50\end{array}$

PITTOSPORUM. A broad-leaved evergreen shrub with bright foliage and white, sweetscented flowers in spring. Unsurpassed for seaside planting; not particular as to soil conditions but must have good drainage. Prices of both varieties. Each Per 10

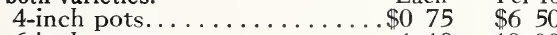
6 -inch pots. . . . . . . $110 . \ldots \ldots 00$ 8 -inch pots.............. $175 \quad 1650$

Field-grown, spade-balled.

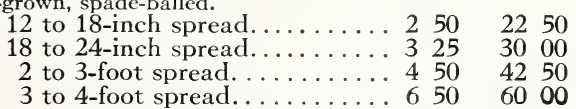

Tobira. Hardy; foliage dark green, shiny. Can be pruned to any desired shape; grows well in shade. Makes a fine hedge.

Tobira variegatum. Has light green foliage variegated white; fine and showy.

PLUMBAGO capensis. A very showy, lowgrowing evergreen shrub producing an abundance of light blue flowers. It may be grown as a climber, as a shrub, or used as a hedge plant.

capensis alba. A white-flowered form, similar in every way to the blue variety. A desirable white shrub.

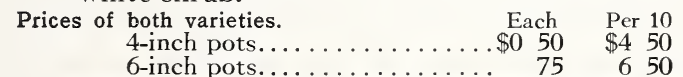

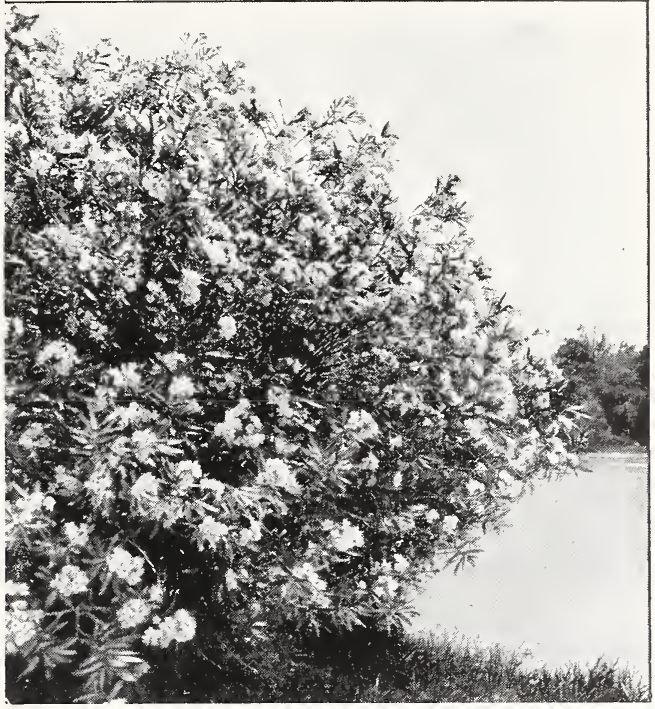

Oleander. See page 30

POMEGRANATE, FLOWERING (Punica). These shrubs are among the most satisfactory for general planting. Beautiful flowers in various shades of white and pink produced all summer.

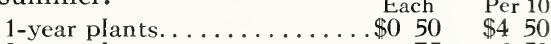

$$
\begin{aligned}
& \text { 2-year plants............... } 75 \quad 650
\end{aligned}
$$

Double White. A strong-growing variety with long, double, creamy white flowers.

Mme. Legrelle. Pink, marked with crimson veins; very full and double.

PRUNUS Laurocerasus (English Laurel). A very beautiful evergreen shrub or small tree with large, bright green foliage. A splendid plant for combining with other shrubs in the border for foliage effects.

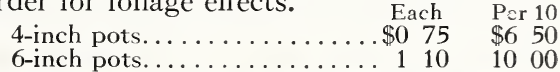

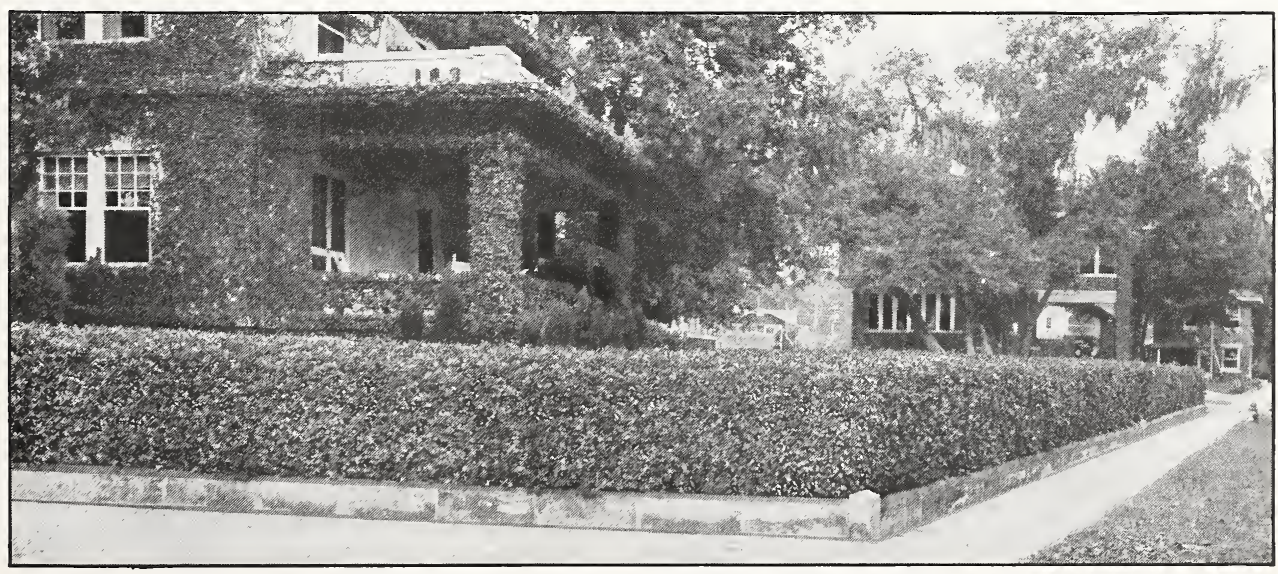

Pittosporum Tobira. makes a beautiful hedge 


\section{SOUTHERN PLANTING FACTS}

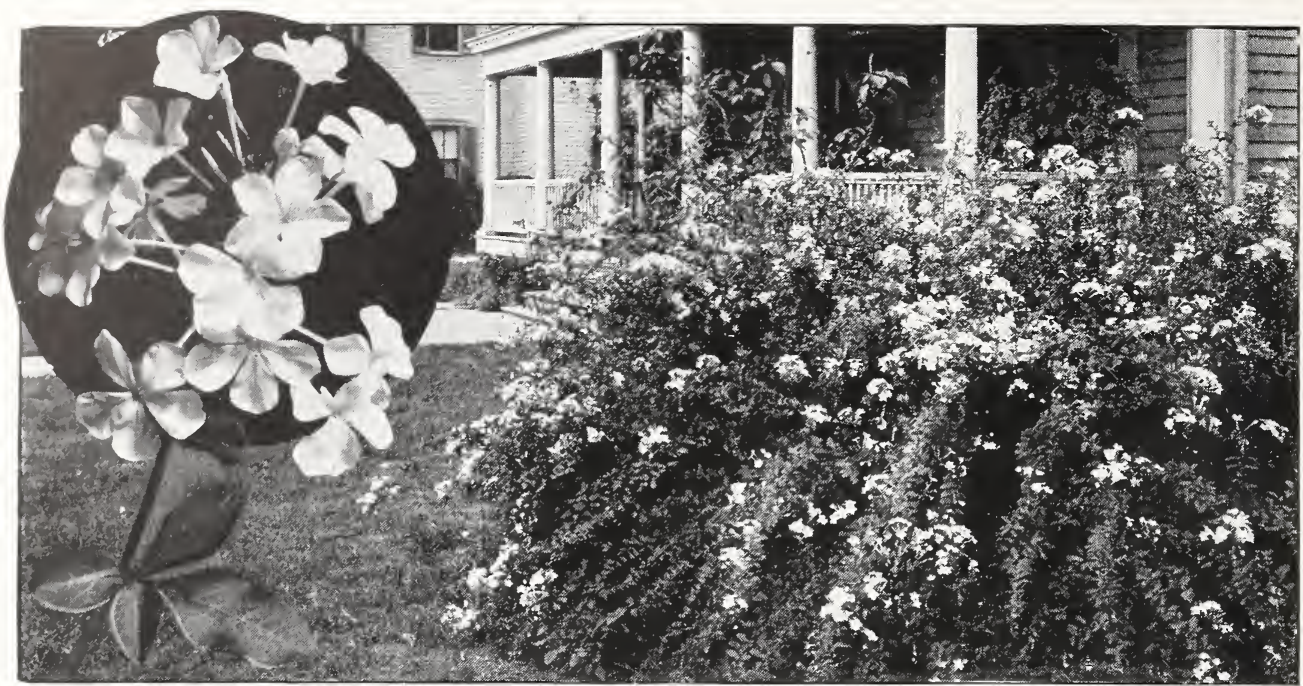

Plumbago capensis. See page 31

\section{SHRUBS AND HEDGE PLANTS, continued}

PYRACANTHA (Fire Thorn). Evergreen shrubs with smaIl, narrow leaves, thorny branches, white flowers in small clusters, and bright red or orange-colored fruits in winter. They are very beautiful shrubs, adapted to sunny Iocations. See varieties below.

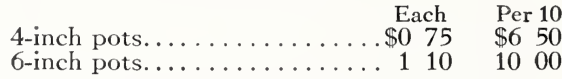

angustifolia. Spreading in growth, with Iong, narrow leaves; orange-yellow berries produced in great abundance.

coccinea Lalandi. A spiny shrub with bright orange-red fruits throughout the winter.

crenulata yunnanensis. Leaves bright green, glossy; fruits shining coral-red. A very desirable shrub.

RAPHIOLEPIS indica (Indian Hawthorn). A fine evergreen shrub, reaching a height of about 5 feet. Leaves roundish, thick, dark green. Flowers white, or pinkish white, in flat bunches, sweet-scented. Hardy.

japonica. A handsome, hardy evergreen shrub, with good bright green foliage and white flowers at the tips of the branches in spring. An upright and fairly rapid grower. This is a very desirable shrub. Valuable for seashore planting.

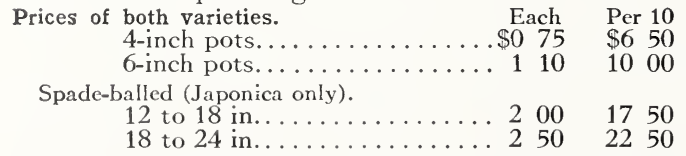

SCHINUS terebinthifolius. An evergreen shrub with dark green, compound leaves and scarlet berries in winter. It is native in Brazil and will be found very satisfactory in Florida from Orlando southward.

$$
\begin{array}{rr}
\text { Each } & \text { Per } 10 \\
8 \text {-inch pots.......... } 125 & \$ 1150
\end{array}
$$

SERISSA fœtida variegata. A low-growing, much-branched evergreen shrub, reaching a height of about 2 feet; leaves dark green, yellow margined; flowers small, white, trumpet-shaped; very desirable where a lowgrowing shrub is required. Fine for tying larger shrubs down to the ground. Each Per 10 4 -inch pots............. \$0 $50 \$ 450$ 6 -inch pots................ $75 \quad 650$

SEVERINIA buxifolia. A low-growing, hardy evergreen shrub closely related to citrus. The leaves are smaII, bright, dark green. Flowers sweet-scented, followed by bright black fruit. It makes a satisfactory hedge. Very satisfactory as a low-growing shrub. Each Per 10 4 -inch pots............\$0 75 \$6 6 -inch pots............... $110 \quad 1000$

SPIRAEA. The Spireas can be planted in masses, around borders or in beds, with excellent results. They bear a profusion of showy flowers in early spring, and a group planting makes a showy mass.

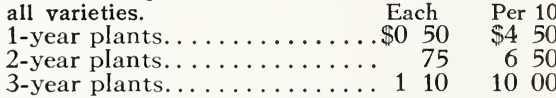

Anthony Waterer. A free-flowering, rather dwarf deciduous Spirea with upright branches and an abundance of brilliant carmine flowers. If the old flowers are cut off as they fade, it will bloom almost continuously through the summer. The Ieaves are green, with yellow variegations.

cantoniensis. Compact-branching shrub, 3 to 4 feet in height, producing a dense mass of pure white flowers; very desirable.

cantoniensis, Double. This is a very beautiful double-flowered form, corresponding in other respects with the single one. The flowers, however, are better distributed through the bush and last longer. 


\section{Glen Saint Mary Nurseries Co. Glen Saint Mary, Florida}

\section{SHRUBS AND HEDGE PLANTS, continued}

\section{Spiræa, continued
Vanhouttei. Branches long and arching;} leaves dark green; flowers produced in clusters along the branches; hardy. This Spirea is very often known as "Bridal Wreath."

For prices of Spiræa, see page 32

SURINAM CHERRY. An evergreen shrub with bright green glossy leaves and producing cherry-like ribbed fruit of delightful subacid flavor. It makes an attractive and unique ornament for the home grounds and is a splendid hedge plant. Adapted to southern Florida and similar climates.

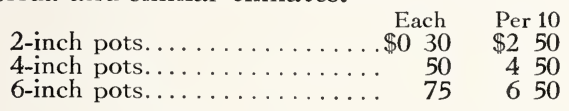

TABERNAMONTANA coronaria. An evergreen shrub with dark glossy green leaves and double white, sweet-scented flowers. It resembles the Cape Jasmine. Half hardy. coronaria grandiflora. A beautiful shrub with large, glossy green leaves and pure white, scented flowers. This is a particularly fine shrub for southern Florida, where it reaches a height of about 6 feet.

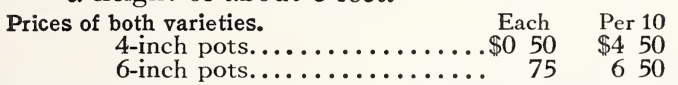

TEA PLANT (Camellia Thea). An evergreen shrub usually reaching a height, with us, of 8 to 10 feet unless pruned back. Large, oval, serrate leaves; white, fragrant flowers $1 \frac{1}{2}$ to 2 inches in diameter. A very fine hedge may be made with Tea Plants.

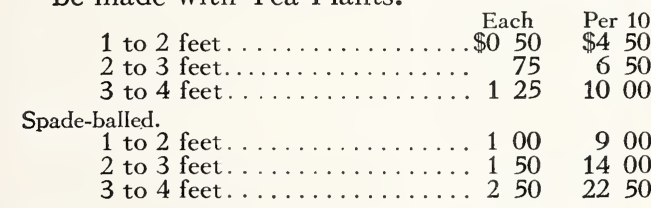

TECOMA capensis. This strong-growing evergreen shrub may be grown either as a shrub or as a climber. The leaves are dark green and the bright scarlet flowers are produced at intervals throughout the summer. Tender; adapted from middle Florida southward.

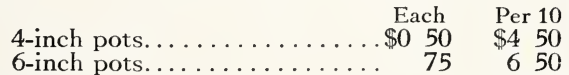

THUNBERGIA erecta. A very handsome, densely branched evergreen shrub, adapted to southern Florida or for pot-culture farther north. It grows to a height of 5 to 6 feet. The flowers are trumpet shaped, blue-purple, with deep yellow throat, and the handsome foliage is dark green.

erecta alba. This is a white-flowered form of $T$. erecta, differing from the type in having white flowers with yeliow throats. Prices of both varieties.

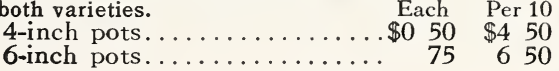

VIBURNUM. The Viburnums offered below are aII evergreen shrubs with white, sweetscented flowers. They have proved to be very desirable garden shrubs for the South.

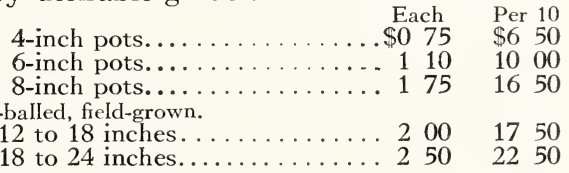

18 to 24 inches................. $250 \quad 2250$

macrophyllum. An upright, evergreen shrub with bright shiny leaves that look as though varnished. It is a striking shrub, very satisfactory and dependable.

odoratissimum. The leaves are broad and glossy and the shoots brownish tinted when young. The flowers are white, fragrant, and produced in large panicles.

suspensum. This is a fine shrub of spreading habit adapted to either sun or shade. The flowers are white, sweet scented, and produced in clusters suspended from the branches.

YUCCA aloifolia. Of plants adapted to seaside conditions and for growing on poor, sandy soils, this is one of the most valuable. The leaves are long, narrow, rigid, spine-tipped. The flowers are yellowish white, large, borne in gorgeous spikes from the center of the

$\begin{array}{rrrr}\text { leafy crown. } & \text { Each } & \text { Per } 10 & 100 \\ 12 \text { to } 18 \text { inches...... } \$ 075 & \$ 650 & \$ 5000 \\ 18 \text { to } 24 & 100 & 900 & 7500\end{array}$

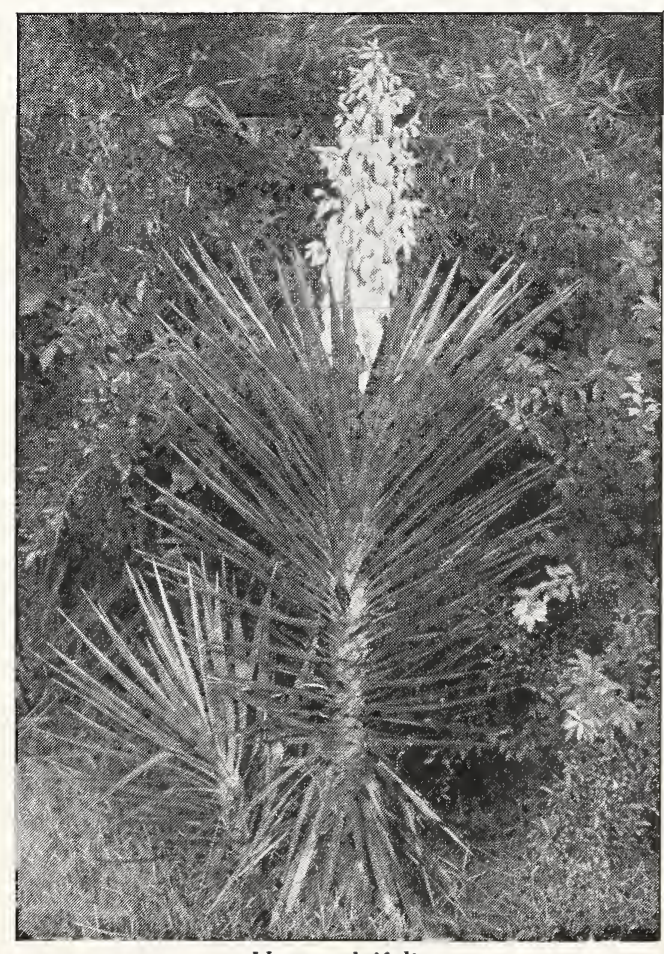

Yucca aloifolia 


\section{Glen Saint Mary Nurseries Co. Glen Saint Mary, Florida}

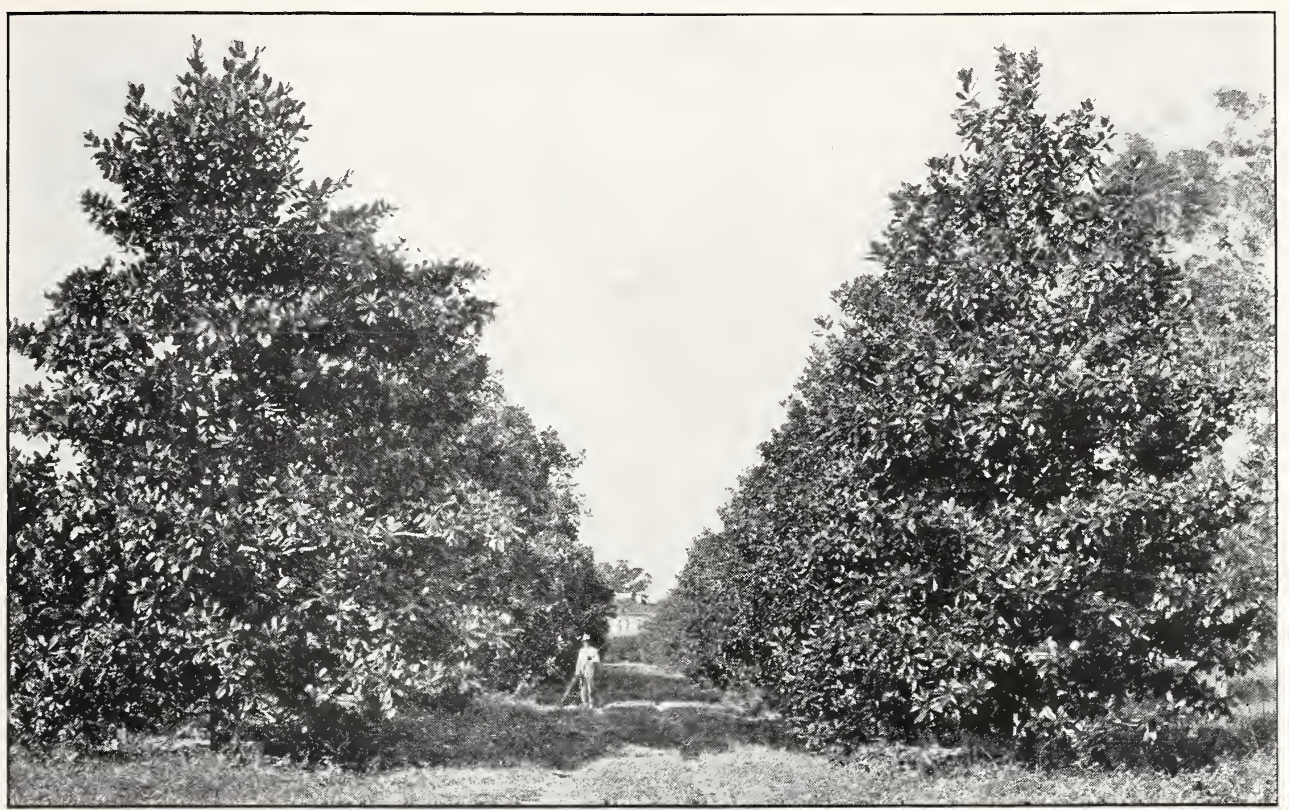

Avenue lined with Magnolia grandiflora. See page 36

SHADE TREES, continued

CHERRY LAUREL. A fine native broad-leaved evergreen tree with bright shiny leaves, reaching a height of 30 to 40 feet when fuIl grown. May be pruned in any shape. Fine for hedges and screens.

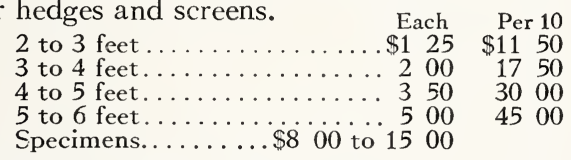

DOGWOOD, White (Cornus florida). A small deciduous tree, with spreading, bushy top and bright green leaves. The flowers, with their large, white bracts, appearing in spring before the Ieaves, make the Dogwood one of the most striking ornamental trees. The showy, bright scarlet fruit ripens in autumn, making it very attractive at this season.

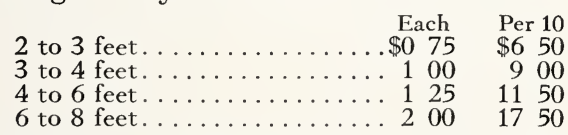

EUCALYPTUS. Rapid-growing evergreen Australian trees, many of which do splendidly in Florida. We have made a careful selection of the most desirable sorts. They are aII potgrown and easily transplanted.

$$
\begin{aligned}
& 2 \text { to } 3 \text { feet............\$ } 50 \text { 50 } \$ 450 \\
& 3 \text { to } 4 \text { feet................ } 50 \text { 50 } \$ 450 \\
& 4 \text { to } 6 \text { feet. .............. } 100 \quad 900
\end{aligned}
$$

robusta (Swamp Mahogany). A rapid-growing tree, with spreading, reddish branches, Iarge, oval, dark green, pointed leaves and rough, dark brown bark. Perhaps the most desirable Eucalyptus for shade.

rudis. Very fine for street planting; withstands extremes of both heat and cold.
Eucalyptus rostrata. Grows well under a great variety of conditions. Leaves Iong, narrow, and pointed. Stands extremes of heat and cold.

tereticornis. A valuable timber Eucalyptus, weIl adapted to trying conditions. Leaves rounded resembling a poplar leaf somewhat in shape. Hardy.

viminalis. A very handsome Eucalyptus, with Iong, pendulous branches. This species is one of the hardiest and for 6 years has withstood the winters at GIen Saint Mary with only occasional partial freezing back.

FLOWERING PLUM. The flowering cherries of Japan are world-famed, but Japan owes more of her winter and early spring color to her Flowering Plums. The cherries are not adapted to the Lower South, but the Plums are splendid. This PIum is one of the finest small-sized deciduous trees for planting in the South. In northern Florida it blooms in January, before the leaves appear, producing a gorgeous mass of double, pink, sweet-scented flowers. It is very handsome and desirable.

$$
\begin{aligned}
& 2 \text { to } 3 \text { feet............ } \$ 075 \quad \begin{array}{l}
\text { Pach } 10 \\
\$ 650
\end{array} \\
& 3 \text { to } 4 \text { feet.................. } 100 \quad 9600
\end{aligned}
$$

FL.OWERING WILLOW (Chilopsis linearis). A small, deciduous tree with spreading, crooked branches and narrow, pointed, willow-like foliage. Its tubular, Iilac flowers are produced in early summer. Height 12 to 15 feet.

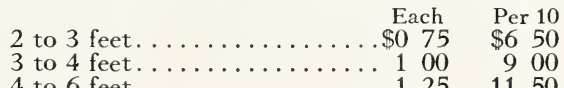




\section{SOUTHERN PLANTING FACTS}

\section{SHADE TREES, continued}

FRAXINUS velutina (Rio Grande Ash). A rapid-growing deciduous tree, particularly adapted for planting on moist soils and on those which may be salt. The leaves are dark green, glossy, and clothe the tree throughout most of the year. It is a rapid grower, reaching a height of about 40 feet.

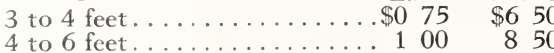

Each Per 10

GORDONIA Lasianthus. A fine evergreen tree, reaching a height of 50 to 60 feet, with large, dark green, shiny leaves. Flowers white, resembling small magnolias, and borne freely on young trees. Grows satisfactorily on different types of soil.

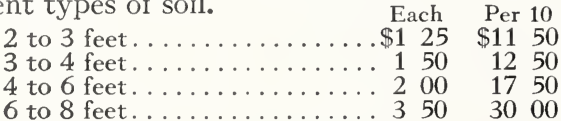

HOLLIES. These fine evergreen trees are at home all over the South. They are not surpassed in beauty by any of our broad-leaved evergreens. We are now in position to offer three varieties, all grafted from selected fruitbearing trees. We can furnish all three species with balls of earth if desired.

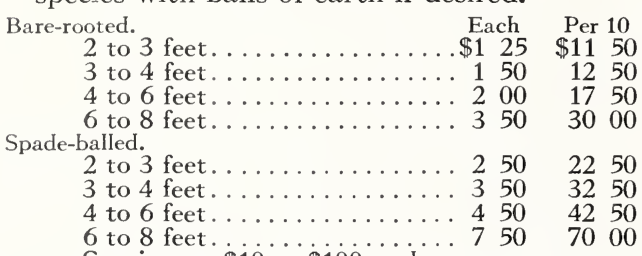

American Holly (Ilex opaca). The Christmas Holly. Its bright green, spiny leaves and brilliant scarlet berries make it one of our handsomest evergreen shade trees.

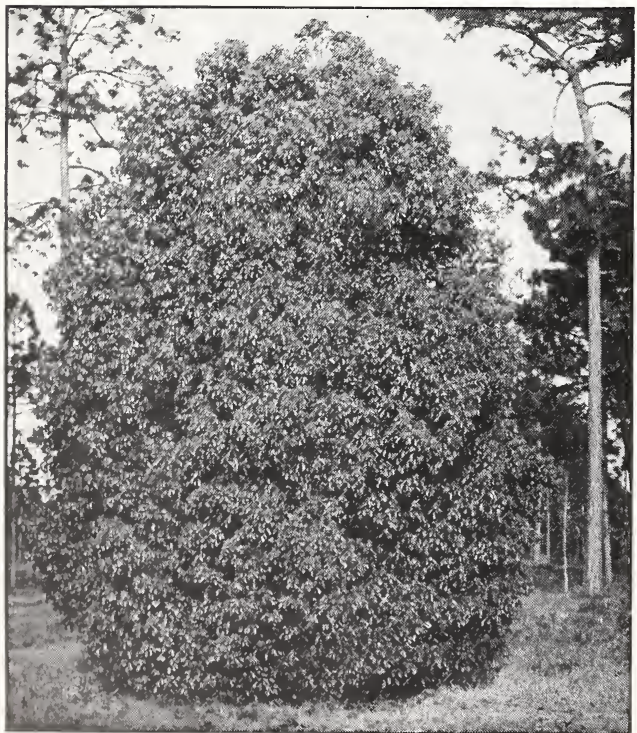

Camphor Tree (Cinnamomum Campbora). See p. 34

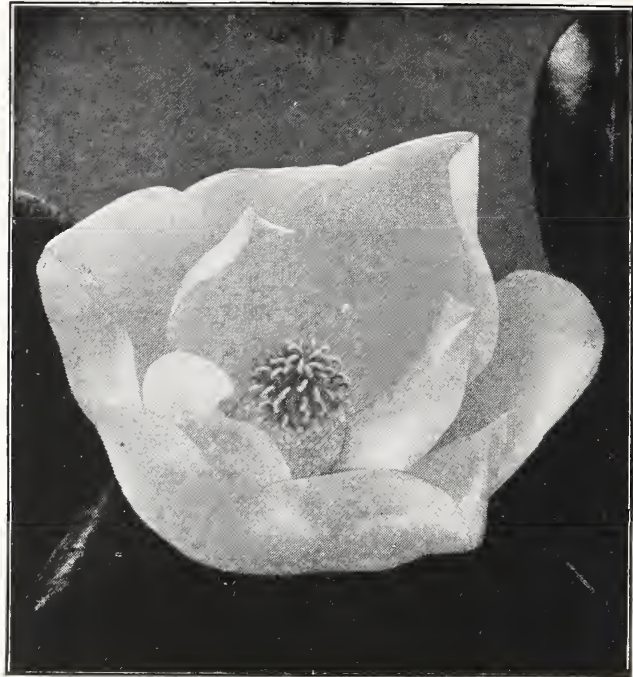

Magnolia grandiflora

Hollies, continued

Dahoon Holly (Ilex Daboon). Leaves bright and glossy, branches literally covered with bright red berries. One of the most valuable broad-leaved evergreens in our list and we strongly recommend it.

Myrtle-leaved Holly (Ilex myrtifolia). This attractive evergreen Holly has small, bright green leaves, and produces bright red berries.

KGELREUTERIA formosana. A small or medium-sized tree with deciduous foliage resembling that of the Texas UmbreIla. Flowers yellow, in large panicles in early fall, followed by beautiful pink fruits.

$$
\begin{aligned}
& 2 \text { to } 3 \text { feet............ Each } \quad \begin{array}{c}
\text { Per } 10 \\
50
\end{array} \\
& 3 \text { to } 4 \text { feet................... } 75 \text { 6 } 60 \\
& 4 \text { to } 6 \text { feet............. } 100 \quad 850
\end{aligned}
$$

MAGNOLIA glauca (Sweet Bay). This beautifuI Magnolia, evergreen in the South, has small sweet-scented flowers and bright green leaves that are silvery gray beneath. The color of the top of $M$. glauca is variable. When blown by the wind, it is gray-green; when still, it is green. Very fine and desirable.

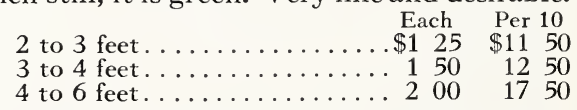

grandiflora. Grandest broad-leaved evergreen of the southern forests. Leaves large, bright shining green above, usually coated with brownish hairs beneath. Flowers beautiful, often 8 to 10 inches across, waxy white, lemon-scented, produced throughout a period of two to three months. $M$. grandiflora is without a superior among broad-leaved evergreen trees anywhere in the world.

For prices of Magnolia grandiflora, see page $\mathbf{3 7}$ 


\section{Glen Saint Mary Nurseries Co. Glen Saint Mary, Florida}

\section{SHADE TREES, continued}

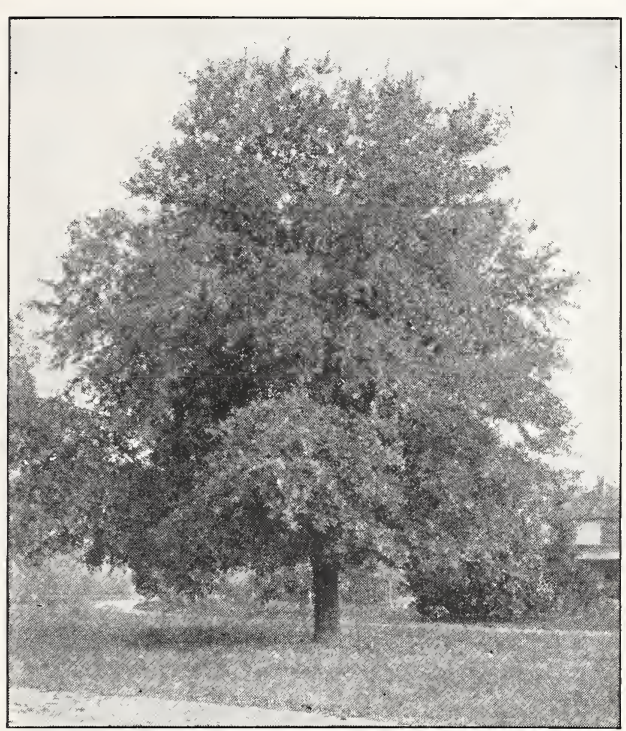

The Live Oak has no superior as a shade tree

Prices of Magnolia grandiflora. Each Per 10 2 to 3 feet.............\$1 25 $\$ 1150$ 3 to 4 feet................. 1 50 1250 4 to 6 feet.............. $200 \quad 1750$

6 to 8 feet.............. $350-3000$

8 to 10 feet................6 $600 \quad 5000$

Machine-balled and burlapped.

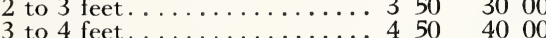
3000
4 to 6 feet. ................. $600 \quad 5500$
6 to 8 feet.
Specimens, $\$ 15$ to $\$ 100$ each.

MAPLE, Scarlet (Acer rubrum). One of our handsomest Maples, growing to Iarge size, with moderately spreading branches. The Ieaves are three to frve-pointed, light green above, white beneath, changing to vivid shades of scarlet and gold in autumn. In early spring the bright red flowers are produced, followed by the red seeds.

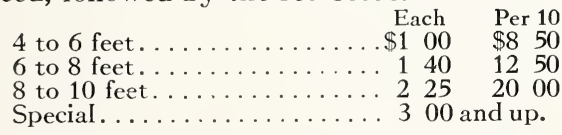

OAK (Quercus). Long-lived, of rapid growth, with graceful, rounded tops. The Oaks are among our most valuable and common shade and ornamental trees and can be grown almost anywhere.

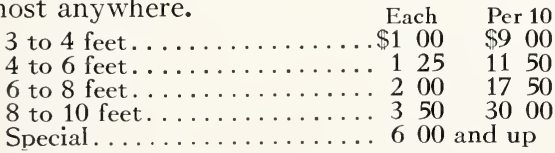

Laurel (Quercus laurifolia). A medium- or large-sized almost evergreen tree, with thick, rounded head and slender branches. The leaves are oblong, sometimes lobed, dark green. A handsome shade and avenue tree, and of commanding appearance as single specimens.
Oak, continued

Live Oak. A fine Iong-lived evergreen tree, native to the South. Its symmetrical shape and dark, glossy green leaves make it a very handsome and desirable tree for lawn planting. Our stock is produced from a very fine type.

POPLAR (Populus Simoni). A tall, rapidgrowing, small-leaved deciduous Chinese Poplar of upright, pyramidal habit, more beautiful than Lombardy, and better adapted to the Lower South. Meyer's introduction.

\begin{tabular}{|c|c|}
\hline $\begin{array}{l}3 \text { to } 4 \text { feet. } \\
4 \text { to } 6 \text { feet. }\end{array}$ & $\begin{array}{r}\text { Each } \\
. \$ 075 \\
1 \\
100 \\
1 \\
120 \\
225\end{array}$ \\
\hline
\end{tabular}

RED-BUD (Judas Tree; Cercis canadensis). A small deciduous tree, 20 to 30 feet high, with rounded handsome leaves, producing an abundance of rosy pink flowers in early spring which make it an attractive object in any landscape. Plant on well-drained land.

\begin{tabular}{|c|c|}
\hline $\begin{array}{l}2 \text { to } 3 \text { feet. } \\
3 \text { to } 4 \text { feet. } \\
4 \text { to } 6 \text { feet. } \\
6 \text { to } 8 \text { feet. }\end{array}$ & $\begin{array}{r}\text { Each } \\
. \$ 075 \\
.100 \\
.1125 \\
.2200\end{array}$ \\
\hline
\end{tabular}

SWEET GUM (Liquidambar styraciflua). Rapidgrowing, native deciduous tree. Branches often corky winged. Leaves bright green, five to seven-pointed; in autumn brilliantly colored in shades of red and crimson. Makes a handsome shade tree.

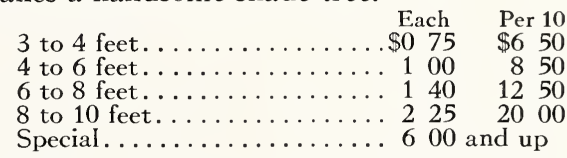

SYCAMORE (Platanus americana). Among deciduous trees the Sycamore is one of the most rapid-growing. It is easily transplanted, even in large sizes. The white trunk, wide-spreading branches, and Iarge leaves mark it as an unusual and attractive long-lived tree.

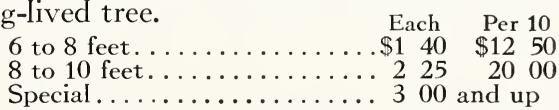

TEXAS UMBRELLA. A medium-sized deciduous tree, with flat, umbrella-like top. Foliage finely divided, dark green, casting a dense shade. A very desirable shade tree.

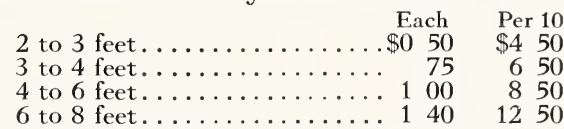

WHITE JUDAS TREE (Cercis canadensis alba). A very beautiful variety of Red-bud or Judas Trce with pure white flowers. It is one of the most attractive of the early spring-flowering trces and worthy of a place in any garden.

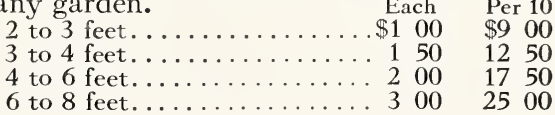




\section{SOUTHERN PLANTING FACTS}

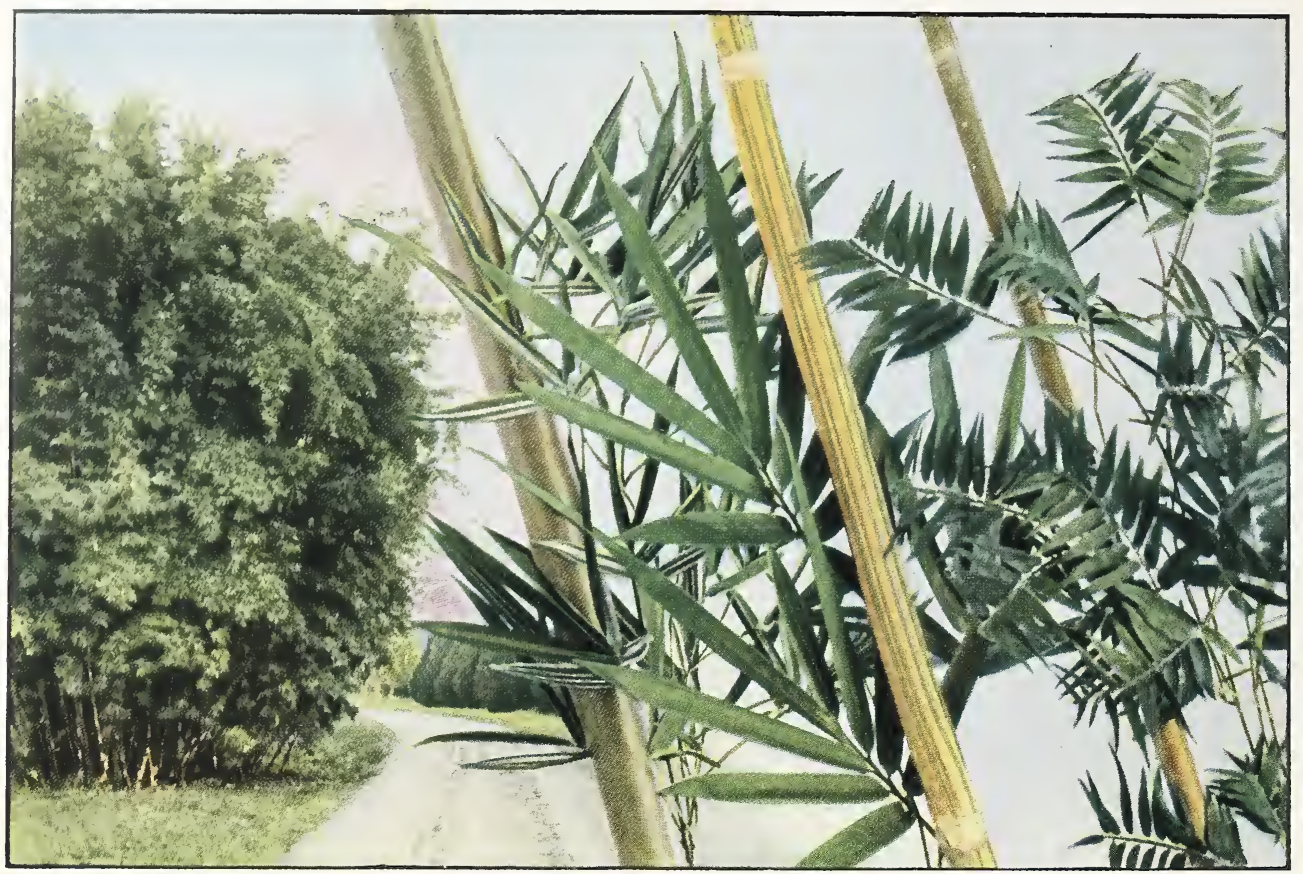

Plant and cane of Bambusa argentea striata

Bambusa verticillata; Bambusa disticha

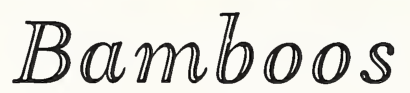

$\mathrm{T}$ HERE are no more beautiful plants than the Bamboos. The long, willowy canes and fine foliage give a delicate, pleasing effect. Under suitable climatic conditions they will grow on very poor soil, if well supplied with plant-food. Good drainage they should have, and moisture in abundance they need. Either organic commercial fertilizer or stable manure may be used to good advantage. The large-growing varieties of Bamboos make excellent windbreaks, and are also valuable for tall hedges and as screens for unsightly buildings or other objects. They may be used for hedges, low or high. For tropical effects they are unsurpassed. AII varieties are hardy at Glen Saint Mary, and two, Arundinaria japonica and Pbyllostacbys aurea, are hardy to Washington, D. C.

Arundinaria japonica (Bambusa metake). This running Bamboo reaches a height of 15 feet when weII grown. Leaves large and broad. Though a running variety it is readily grown in clumps by cutting or breaking off the new shoots that come up at a distance from the main clump. Hardier than any of the Bamboos listed.

Bambusa argentea. A clump Bamboo with small green canes and green leaves. It is one of the best for pruned hedges and screens. When left unpruned it grows to a height of about 25 to 30 feet.

Bambusa argentea striata. In this variety of clump Bamboo the canes are green, striped with yellow near the base. The leaves are green, variegated with whitish stripes. This variegation is quite pronounced when the leaves are young, scarcely noticeable when old. It grows to 40 feet and forms large clumps.
Bambusa disticha (Arundinaria falcata). Fernleaved Bamboo. One of the handsomest of the hardy clump Bamboos. The canes are smaII and a well-grown clump rarely exceeds 15 feet in height. Its foliage is fine, small, and fernlike, gray-green on the under side, green above. Clumps occasionally show a break toward a larger-leaved form.

Bambusa verticillata. The yellow canes of this upright growing clump Bamboo are striped with green. It grows to a height of about 30 feet.

Phyllostachys aurea (Bambusa aurea). A running Bamboo with yellow canes. It may be readily grown in clumps by cutting out the distant canes as they come up. The clumps formed by this variety have a distinct, open, and graceful appearance, quite different from other Bamboos. Very hardy.

Bambusa argentea, argentea striata, aurea, metake, disticha, and verticillata.

Each Per 10

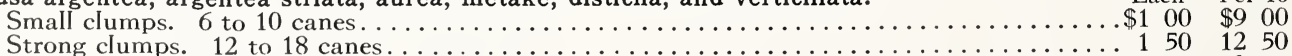

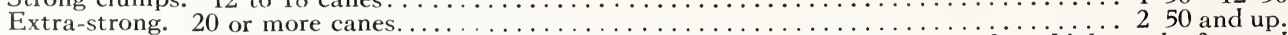

Pruned Specimens, Argentea only. These have well-shaped heads about 2 to $2 \frac{1}{2}$ feet high and of equal spread. Very formal. $\$ 2.50$ each; $\$ 22.50$ for 10 . 


\section{Glen Saint Mary Nurseries Co. Glen Saint Jary, Florida}

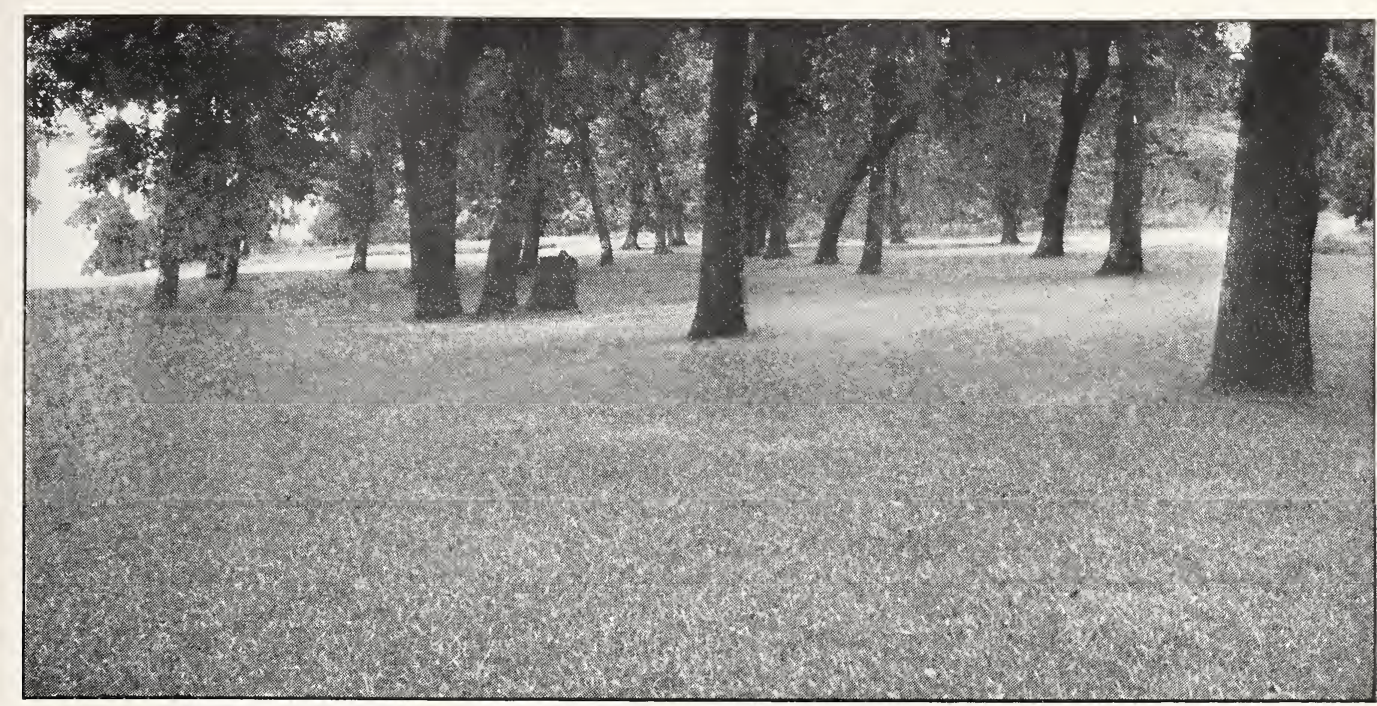

A fine Centipede Grass Lawn

\section{Lawn Grasses and Ground-Covers}

W

ITHOUT a lawn, an open space covered with good turf, the beauty of the home setting cannot be realized, no landscape planting is complete, and no garden is finished. It is the canvas on which the whole garden picture is spread, and, difficult though the securing of a good lawn may be, it is worth all the time and trouble given to its making and to its upkeep.

In the Lower South, lawns may be covered with a number of different grasses, the most important of which are given below. Two or more of these may be used together, or only one. Though some of these are occasionaIly established by seeding, they are nearly always planted with cuttings. The best planting season is in spring and summer, though Far South lawns may be set in winter. In the colder sections, where grasses usually turn brown in winter good effects can be secured by sowing Italian rye seed in the lawn. This does no injury to the permanent grass, and the bright green of the rye makes a very pleasing appearance during the winter season.

The soil should be weIl filled with humus, rich, weIl prepared, and made fine, as for planting flower seeds. Grass cuttings are commonly planted in rows $12 \times 12$ inches or $12 \times 6$ inches. A bushel of grass contains from 1,500 to 2,000 cuttings. Water must be used freely until the cuttings are rooted and the ground kept free of weeds until the surface is covered. Commercial fertilizer, the ammonia in which is derived largely from organic sources, is necessary for good results. Under most conditions, three applications - spring, midsummer, and autumn, at the rate of three pounds per 100 square feet each time-should be made and immediately washed down into the roots of the grass with water from the hose. Frequent cutting, once or twice weekly, is necessary, and the clippings should never be removed. Running grasses of the kinds used in the South must not be cut closely.

Sometimes it is impossible to secure a good grass lawn in certain places. This is often the case on the barren, root-filled soil beneath trees, on hard, poor soils, and on steep, sloping banks. In such locations it is usually best not to attempt grass at aII, but to use a ground-cover plant of some other kind. Fortunately, there are several plants that give very satisfactory results when used in this way.

\section{LAWN GRASSES}

Bermuda Grass (Cynodon dactylon). A fineleaved grass which has Iong been a favorite for lawn purposes in the Lower South. Grows with surface and underground running stems. Very hardy. $\$ 2$ per bus. cuttings.

Carpet Grass (Axonopus compressus). This is a valuable lawn grass which is coming into very general use. It resembles St. Augustine Grass in habit of growth. Retains its color weIl in cool weather. $\$ 2$ per bus. cuttings.
Centipede Grass. In 1919, a new grass, Eremochloa opbiuroides, to which the common name Centipede Grass has been applied, was introduced from China by the United States Department of Agriculture. In China it is highly esteemed as a lawn and pasture grass. It was thoroughly tested at the Florida Experiment Station where we secured it in April, 1925. Since then it has been widely distributed and tested in different localities on different soil 


\section{SOUTHERN PLANTING FACTS}

Centipede Grass, continued

types. Under all conditions it has given satisfaction, and for light soils it has no superior.

Centipede Grass grows rapidly and covers the ground with branching surface runners. It does not appear to make much difference when it is set out, and we have successfully transplanted it in every month from January to October. Of course, it grows most quickly during moist summer weather. It is not attacked by chinch bugs or mole crickets.

The leaves are not so fine as those of Bermuda, which they resemble in color, nor yet so coarse as those of Carpet and St. Augustine Grasses. It stands cutting weIl and makes a very close, well-covered lawn. Beyond being turned brown, it is not affected by cold weather in northern Florida, and it appears to be quite as hardy as Bermuda. Because it roots deeply, it is not readily injured by drying, and even if it be dried and withered it comes back green and vigorous when watered.

A bushel of Centipede Grass will make about 1,800 cuttings, and if quick covering is desired, these may be set 12 inches apart each way in well-prepared and fertilized ground. If kept well watered, a complete lawn can be secured in 90 to 120 days under favorable conditions. Seed of this grass is not available and propagation is by cuttings only. Price, cuttings, \$4 per bus.; $\$ 3.50$ per bus. in lots of 5 bushels.

St. Augustine Grass (Stenotaphrum secundatum). A broad-leaved grass, spreading by creeping surface stems, having no superior as a cover for shady locations. May be grown close to, or even where covered at times by, sea spray or brackish water. $\$ 2$ per bus. cuttings.

Pampas Grass (Cortaderia argentea). A Iarge, strong-growing grass producing splendid clumps 6 to 8 feet high, with white, plumelike flowers. Not a lawn grass but very ornamental for screens or individual specimens.

Small clumps..............\$1 00 \$9 00

Strong clumps.................. $150 \quad 1250$ Extra-strong clumps........... 250 and up

\section{GROUND.COVERS}

English Ivy (Hedera belix). For growing under trees and in shady places, the English Ivy is a very valuable plant with which to cover the ground. Always it is a rich dark color, and in many sections it will be found very satisfactory. Price, 35 cts. each, $\$ 3$ for 10.

Liriope. These evergreen plants grow in tufts and belong to the lily family. The leaves are grass-like, dark green, gracefully curved, 6 to 8 inches long. In summer they produce spikes of beautiful Iavender flowers resembling grape hyacinths.

The Liriopes grow on from year to year with little attention, gradually increasing in size by additions to the clumps. They grow equally weII on moist or dry soil, in sun or in shade. Such frosts as come to the Southland have no effect on them, and tropical heat never wilts them. Indeed, they stand unequaled among ground-cover plants.

Two Liriopes are available: One with broad leaves and dense spikes of flowers, the other with narrower leaves and more open flower spikes. In addition to their value for groundcover, they make splendid plants for porch boxes, and urns and as an edging for flowerbeds and borders. 25 cts. each, $\$ 2$ for 10 .

Ophiopogon japonicus. A fine-leaved, dark green, grass-like plant that usually grows to a height of about 6 inches. It spreads out by means of short underground stems and forms a dense covering. To keep it in good condition it is advisable to cut it off at the ground every spring with a sharp hoe. 50 cts. for $10, \$ 3.50$ per 100.

Weeping Lantana (Lantana delicatissima). There is no finer ground-cover than this. Its good foliage and beautiful lilac-colored flowers make it especially charming. It is a fine plant for banks or sloping ground in full sunshine. Also a valuable vine for lower heights. Price, potgrown, 50 cts. each, $\$ 4.50$ for 10 .

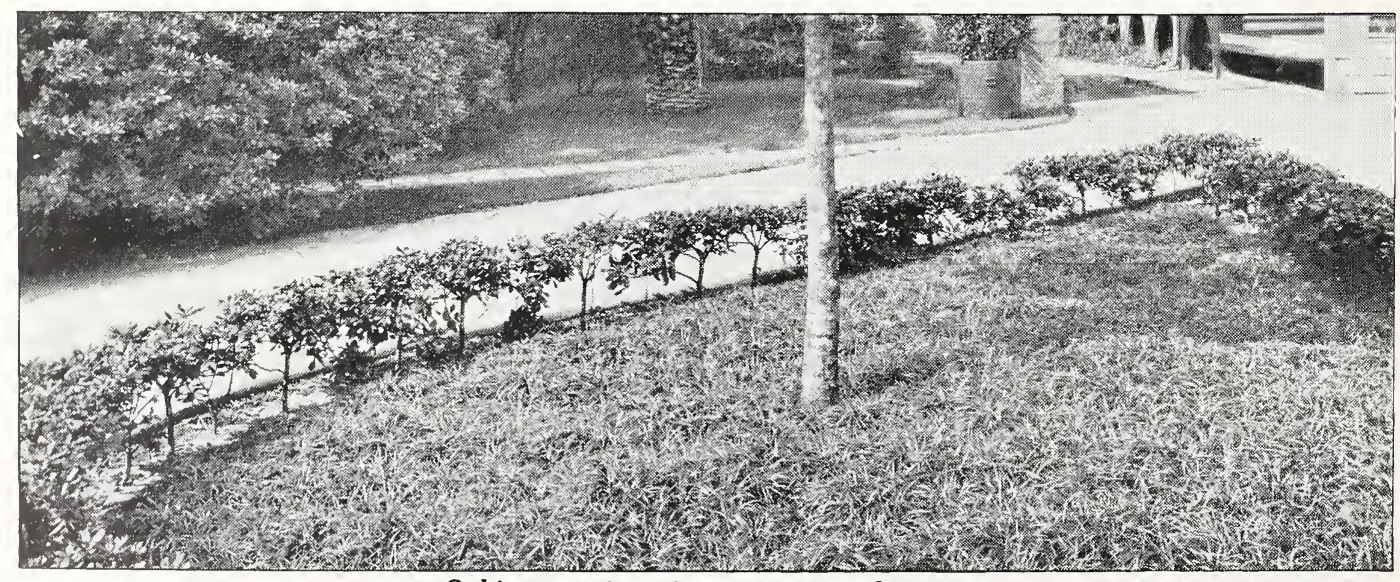

Ophiopogon japonicus as a ground-cover 


\section{Glen Saint Mary Nurseries Co. Glen Saint Mary, Florida}

\section{Vines}

$7 \mathrm{O}$ add to the beauty of the home and its surroundings, Vines of different kinds are unsurpassed. If many bare, unsightly walls were covered by them, they would become things of beauty, for 1 Vines have the power to soften lines and cover up imperfections. Where it is desired to give an

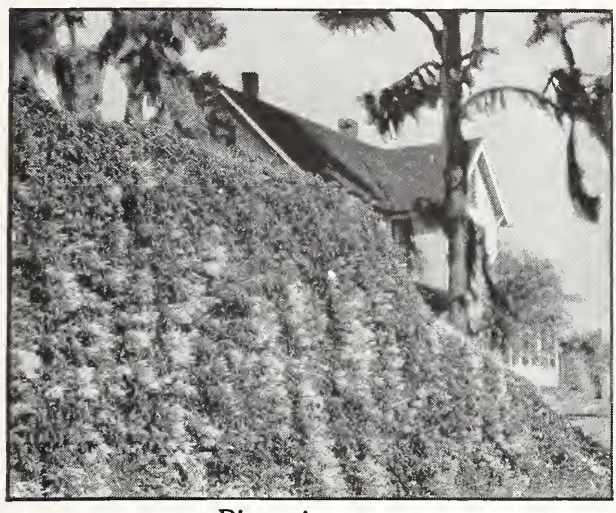

Bignonia venusta appearance of age to a building, they are unequaled.

Nothing can surpass the glory of the Wistaria, the Yellow Jessamine and Bignonia speciosa, when in full bloom. The Ficus repens and Bignonia Chamberlayni are well adapted for brick walls, or surfaces where a Vine is required to climb by fastening itself. The Honeysuckle and Trumpet Vine are splendid for covering mounds, dead trees and fences. The Yellow Jessamine, the two Honeysuckles, Allamanda and Rhyncospermum are evergreen, and where an evergreen covering is desired, they should be given preference. The Rhyncospermum, Yellow Jessamine and Trumpet Honeysuckle are sweet-scented. Climbing Roses and Muscadine Grapes are useful for these same purposes.

For best results, the land should be well prepared, and, if planted near brick walls, the mortar and brickbats should be removed. Dig deeply and mix a fair amount of commercial fertilizer with the soil about two weeks before planting. After they are established, commercial fertilizer or stable manure may be used as a surface dressing. With good drainage, Vines require plenty of water.

PRICES ON VINES.

Small plants

Medium plants....

Strong plants

Extra-strong plants

Bougainvillea, Crimson Lake.

ALLAMANDA Hendersoni. A strong-growing vine, with large, glossy evergreen foliage and large, trumpet-shaped, golden yellow flowers. Tender; adapted to south Florida.

ANTIGONON leptopus (Mountain Rose). A handsome vine with heart-shaped leaves, producing large racemes of rose-pink flowers; adapted to sunny locations.

BIGNONIA. Strong-growing, free-flowering vine with beautiful trumpet-shaped flowers in different shades of yellow, orange and blue.

Chamberlayni. A hardy evergreen vine, producing an abundance of bright yellow flowers in early spring.

radicans (Trumpet Vine). Leaves compound, deciduous, dark green; flowers brilliant orange, produced throughout the summer. Very hardy.

speciosa. A hardy evergreen vine, with glossy leaves. Flower clusters large; purple.

venusta. A very strong-growing vine; evergreen with bright, glossy foliage; flowers borne in great profusion, tubular, bright reddish orange; very showy. Tender.

BOUGAINVILLEA glabra Sanderiana. A showy evergreen vine, bearing large masses of purple flowers. A strong grower and reaches a great height. While tender, with care it does quite well even in north Florida.

Crimson Lake. This variety, with its bright crimson flowers, is one of the most striking vines that can be grown in Florida. $\$ 1.50$ ea.

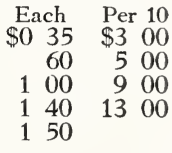

ENGLISH IVY (Hedera belix). The weIlknown English Ivy. An excellent covering for walls and tree trunks. In Florida succeeds best in shaded locations. Evergreen.

FICUS repens (Evergreen Climbing Fig). No other vine is quite so satisfactory for covering foundations of buildings or walls. Smallleaved evergreen vine; quite hardy.

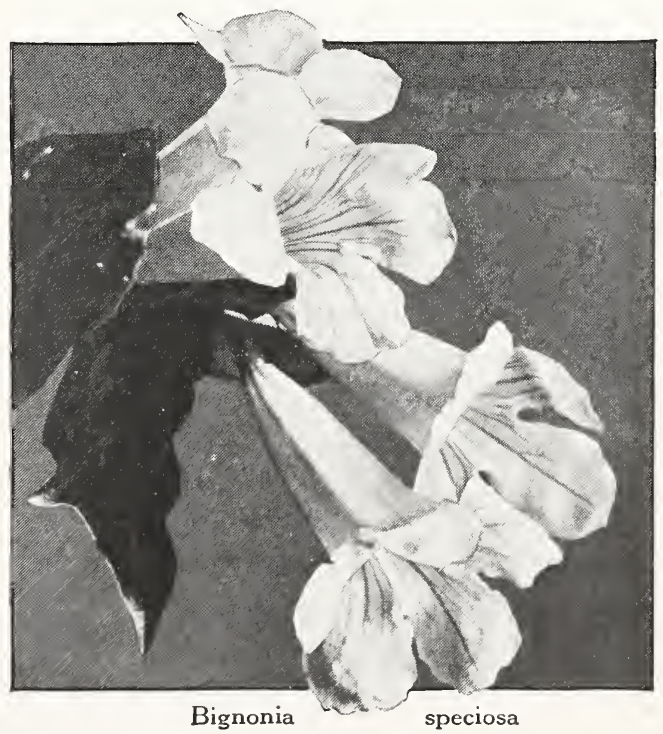




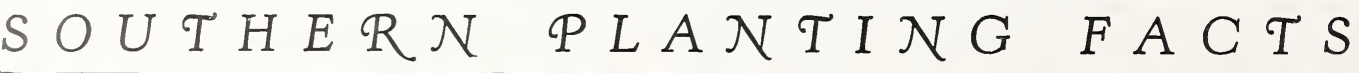

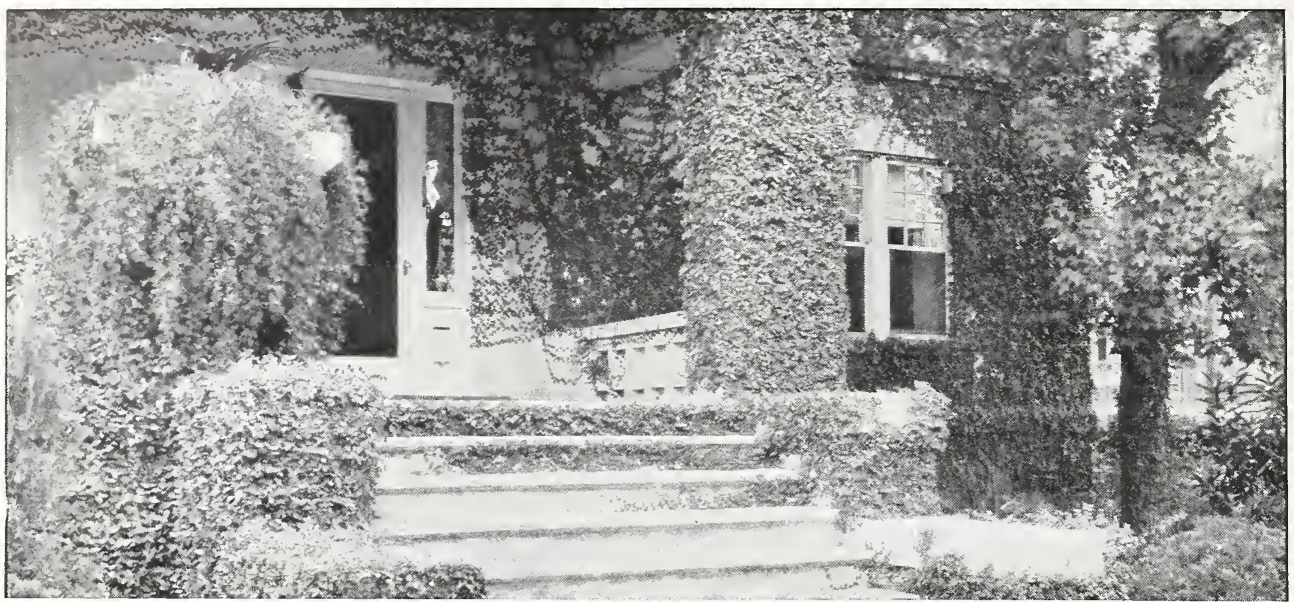

Ficus repens is one of the finest Vines for covering brick, stone or cement

VINES, continued

HONEYSUCKLE (Lonicera). Rapid-growing vines, with handsome flowers. Make a dense covering adapted for porches, trellises and for hiding unsightly places.

Trumpet (Lonicera sempervirens). A beautiful, strong-growing vine, with oval leaves, bluish green in color. Flowers showy, scarlet on the outside, yellow within, large and produced nearly the whole year with us.

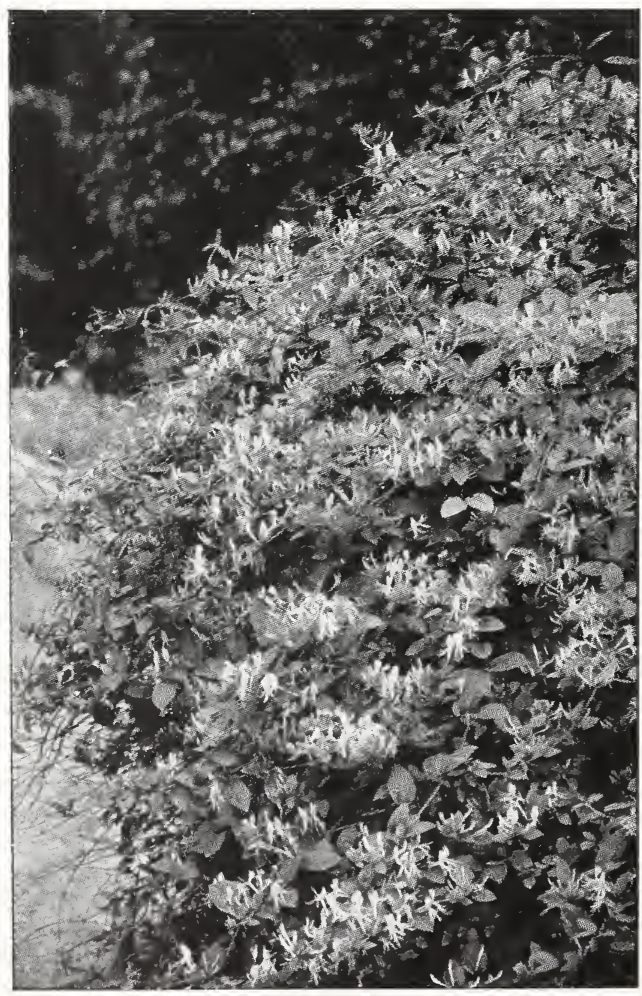

White Honeysuckle
Honeysuckle, continued

White (Lonicera japonica). A rapid-growing evergreen vine, stems slender, leaves dark green. Flowers sweet-scented, white, changing to yellow. Produces a dense covering.

Variegated. This is a very interesting variety (Lonicera aureo-reticulata) of the White Honeysuckle listed above. The foliage is handsomely netted with deep golden yellow, marking it as one of the best variegated vines. Growth, habit, and flowers as in the White Honeysuckle.

JASMINUM pubescens. An evergreen vine or scrambling shrub, with beautiful green foliage and showy, white, star-shaped flowers. It may also be grown in shrub form. Quite hardy and a satisfactory vine.

KADSURA japonica. A hardy evergreen twining vine, with large, dark green leaves. The new growth of vine and leaves is red, giving the plant a very beautiful appearance. Makes a good ground-cover.

PANDOREA jasminoides. This is a beautiful climber with dark green leaves and fine twining stems. The flowers are broadly trumpet shaped, white, suffused with pink in the center.

RHYNCOSPERMUM (Rbyncospermum jasminoides). Leaves rounded, rather small, thick, shiny; flowers produced freely, white, starshaped, smaIl, very fragrant. A very desirable vine. Hardy and evergreen.

THUNBERGIA grandiflora. A strong-growing, woody vine with large, toothed, dark green leaves, broad at the base. The showy, dark blue, tubular flowers are borne in stout, thick racemes. Adapted from middle Florida southward. One of the most satisfactory and beautiful vines. 


\section{$\overline{\text { Glen Saint Mary Nurseries Co. Glen Saint Mary, Florida }}$}

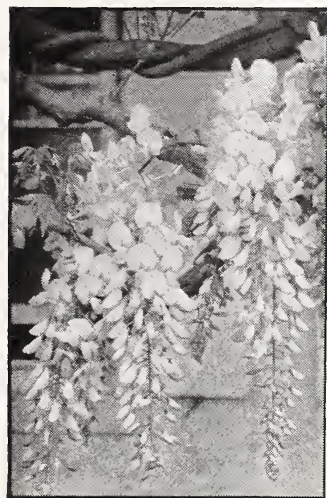

Purple Wistaria
VINES, continued

WISTARIA (Wistaria cbinensis). Magnificent, strong-growing, woody vines, hardy throughout the country. Leaves deciduous; the flowers are borne in large, pointed clusters, with or before the leaves in spring. Wistarias make handsome specimens when staked and grown as trees.

Purple. A very strong-growing sort, producing large panicles of purple flowers.

White. A very fine variety, with large clusters of delicately scented white flowers.

YELLOW JESSAMINE (Gelsemium sempervirens). A slender, rapid-growing evergreen vine. Flowers yellow, fragrant, produced in profusion in early spring.

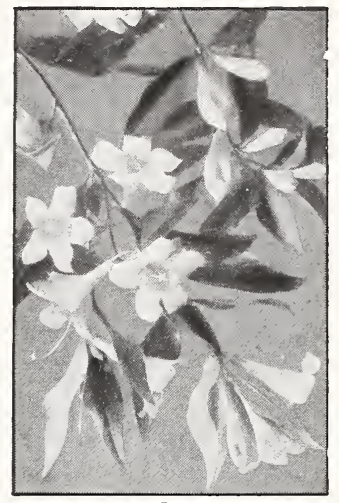

Yellow Jessamine

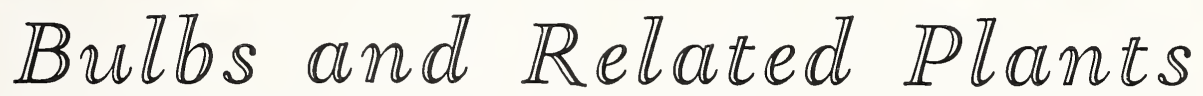

TN NO part of the country can a wider range of really good bulbous and tuberous plants be grown than in the South. Not only can most of the prominent sorts which beautify the Iandscapes of northern localities be grown to perfection, but many beautiful and more tender sorts adapted only to the South may be added to the list. As a rule, when provided with weII-prepared soil, sufficiently rich, good drainage, and sufficient moisture, very little further attention is needed, and throughout the year a profusion of bloom may be secured, giving such an abundance of bright colorings as cannot be secured with any other plants. The varieties offered have been carefully tested and the very best of results may be expected from them.

AMARYLLIS (Hippeastrum vittata, hybrids). For years we have been hybridizing and growing Amaryllis and have brought together a very large collection of these beautiful bulbs. The flowers are very large and the range of colors is wonderful-red, maroon, rose, splashed pink, striped, and variegated. They are easy to grow and unsurpassed among bulbs. Flowering size, 75 cts. each, $\$ 6.50$ for 10 .

ASPIDISTRA lurida. Among shade-loving plants there is none better than the Aspidistra. It is a splendid plant for the shady border, for porch-boxes in shady places, and for indoor decorations. From underground stems, the

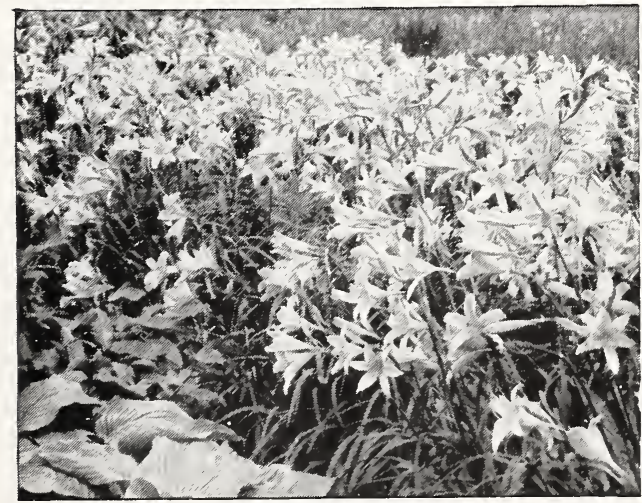

Hemerocallis

\section{Aspidistra lurida, continued}

leaves, borne on rounded green stems, rise to a height of 18 inches to 2 feet. They are large, broad, pointed and dark green. Hardy throughout the Lower South and will thrive in very difficult locations.

Each Per 10 4 -inch pots.............\$1 00 \$9 00 6 -inch pots............... $150 \quad 1400$

CRINUM Powelli. This is one of the most beautiful and satisfactory of Crinums. The flowers are large, funnel-shaped, dark pink, sweet-scented, and borne in umbels.

Powelli album. Very similar to Powelli, but the lily-like, sweet-scented flowers are pure white. Very free flowering and desirable. Bulbs, 75 cts. each, $\$ 6.50$ for 10 .

EUCHARIS grandiflora (Amazon Lily). A lovely bulbous plant from Colombia. Leaves broad, about 12 inches Iong, ribbed. Flowers pure white, cupped, somewhat resembling narcissus, in clusters of two to six on stems 1 to 2 feet long. Fine for cut-flowers. Flowering bulbs, 75 cts. each, $\$ 6.50$ for 10 .

HEMEROCALLIS (Yellow Day Lily). These fine herbaceous perennials are adapted for planting in borders and beds. The leaves are narrow, grass-like, and produced in dense tufts. The flowers, in different shades of yellow, orange, and tawny yellow, according to variety, are produced abundantly. The list of varieties catalogued will give bloom through the season March to July. 


\section{SOUTHERN PLAN TING FACTS}

\section{BULBS AND RELATED PLANTS, continued}

Hemerocallis, continued

Apricot. A low-growing, early-flowering variety with apricot-colored flowers.

Aurantiaca. This variety produces its deep reddish orange flowers on tall stems.

Florham. Large flowers of rich golden yellow. Stems tall. Full bloom in early June. Fine.

fulva. Large tawny or orange-yellow flowers with darker markings of reddish orange.

Gold Dust. Golden yellow flowers, brownish on the outer surface of the petals. Low growing; blooms in March and April.

Kwanso. Similar to Fulva in color and size but the flowers are double. June, July.

Minor. Golden yellow flowers on stems 12 to 15 inches high. Early flowering.

Small, 25 cts. each, $\$ 2$ for $10, \$ 15$ per 100 . Large, $50 \mathrm{cts}$. each, $\$ 4.50$ for $10, \$ 40$ per 100

LIRIOPE. The Liriopes are stemless Iilies, growing in tufts or clumps of dark green, narrow, gracefully curved leaves, a foot or so above the ground. In summer the lilac, grapehyacinth-like flowers are borne in spikes weIl above the leaves, and they last for several weeks. There are two varieties, one with rather narrow leaves and loose spikes of flowers, the other with broader leaves and dense flower-spikes. These valuable plants thrive equally weIl in sun or shade, in moist or dry soil, and stand excessive heat or many degrees of frost without injury. They may be used in the border, as edging for beds, or as pot plants, and are the most valuable addition to our list of plants in many years. 25 cts. each, \$2 for 10.

MARICA gracilis (The Flag Lily). This plant belongs to the iris family. It grows in clumps or tufts, with dark green foliage that bends at the tips. The flower-stalks are like the leaves, and the flowers are produced from the edges, near the tips. Flowers white, blue and brownish within. Very interesting and valuable. 35 cts. each, $\$ 3$ for 10 .

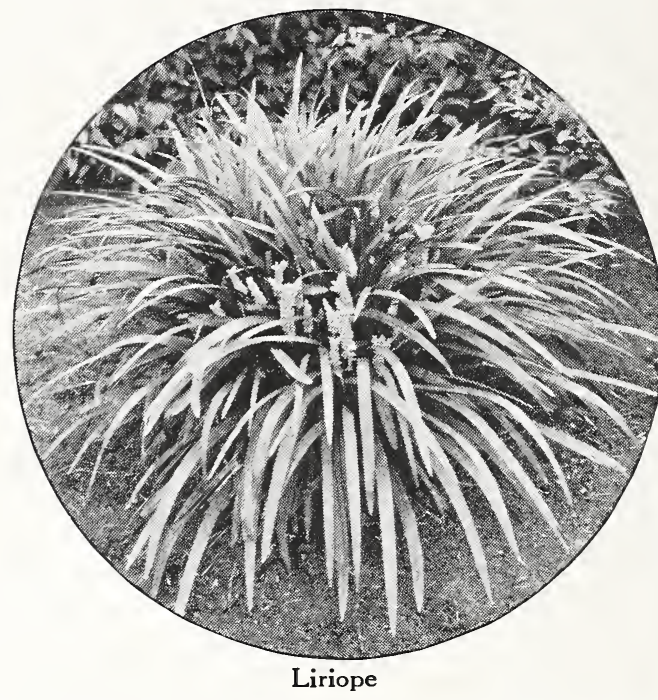

MORFA irioides (Natal Lily). A plant belonging to the iris family, and of easy culture under general Florida conditions. The leaves are sword-like, upright, in fan-shaped arrangement. The flowers are iris-like, white with yelIow and blue central parts. 35c. ea., $\$ 3$ for 10.

OPHIOPOGON jaburan. This plant resembles the liriopes in leaf and habit of growth, but it is a more robust plant, with white flowers, and leaves from 18 to 36 inches long. It is valuable for shady locations and for growing in boxes or pots. 50 cts. for $10, \$ 3.50$ per 100 .

SANSEVIERIA cylindrica. Leaves round, dark green, banded with paler markings, pointed, 12 to 30 inches long. A very unusual plant that will stand much shade and drying. It is not hardy but can be grown out-of-doors in southern Florida. Very satisfactory as a house plant.

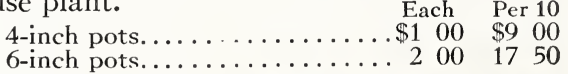

Sansevieria Zeylanica. Leaves sword-shaped, variegated, marked with transverse bands of dark green and grayish white. Very satisfactory in shady places. Not hardy. Adapted for cultivation out-of-doors in southern Florida. It makes a splendid house plant.

4-inch pots ...................... Per 10

6 -inch pots.............. $150 \quad 1200$

Laurenti. This closely resembles $S$. zeylanica in growth-habit, but the leaves are marked on the edges with a band or stripe of creamy yellow. Easily grown and adapted to the same conditions. This is a favorite house plant.

4 -inch pots............\$1 00

6 -inch pots...................

Per 10 $\$ 900$ 1750

Amaryllis

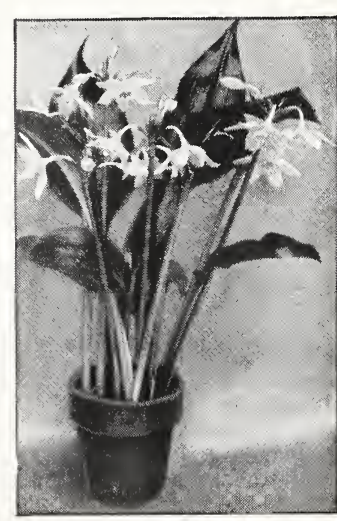

Eucharis 


\section{Glen Saint Mary Nurseries Co. Glen Saint Mary, Florida}

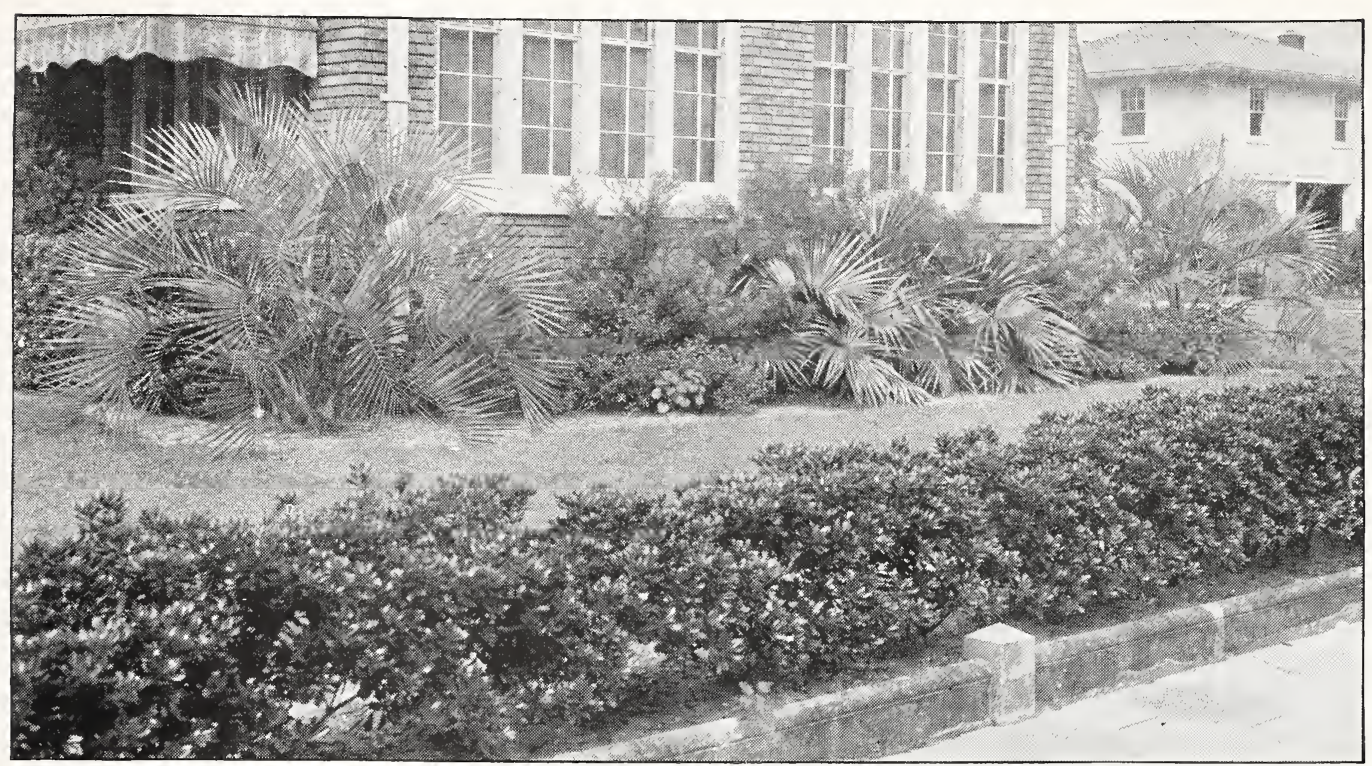

\section{Planting the Home-Grounds}

THAT a planting may be interesting, pleasing, and inviting depends not so much upon the kinds of materials used, as upon the arrangement of the plants and the care given them.

Needless to say, poorly grown, badly cared for plants in various stages of poor condition will add nothing to the home or its surroundings. To grow healthy plants with a wealth of good leaves and flowers requires thorough soil preparation, the liberal use of manure, fertilizer and water. These they must have. Satisfactory results cannot be secured on permanently poor soils, or in places where plants are not happy in their surroundings.

The basic materials for improving soil conditions are a crop of cowpeas or velvet beans grown on the land, if there is time, and plowed or spaded into it, stable manure, poultry manure, vegetable mold from the woods, and organic ammonia fertilizer, such as cotton-seed meal, castor pomace, and tankage. Raw ground bone is a very valuable material of wide use in growing good trees and shrubs. Commercial fertilizers can hardly be dispensed with and should be applied at the rate of a ton or more per acre. All manure should be weIl rotted before using. Dig the ground deeply where the plants are to go; remove all bricks, sticks and rubbish. Economize, if need be, on the plants to be used, but never on the preparation for their planting.

The object in planting the home-grounds is to make a pleasing picture. To secure such a result, a planting-plan, showing the placing of all plants, should be made. This plan will show the location of aIl permanent features, trees or shrubs already in place, the house, garage, boundaries, etc. Necessary walks and drives should be added. For this work a sheet of cross-section paper will be found very valuable.

After this, decide what planting is necessary to give the desired results. Shrubs should be used in masses around the foundations of the buildings, along the boundary lines, and in the corners of the grounds. The whole back yard may be enclosed, giving privacy to the grounds. Leave an open space of lawn. Even a small yard may be made to appear much larger if the open lawn is preserved. On the Iawn side of the borders, the planting should be irregular in outline, here a projecting point formed by the shrubs, there a bay where the lawn seems to project into the border. The shrubbery projections may be the locations selected for particularly attractive specimens of shrubs. In general the taller growing specimens should be kept in the background, using smaller growing plants of different heights to bring the border down to the ground. Annuals may be included in the border, changed from season to season, or bulbous plants and perennials may be set out. The exact location of every plant, tree, or shrub should be indicated.

The plants to be used in the foundation planting must be carefully chosen. Lower growing plants should be selected for spaces beneath windows, taller ones to fit into bare wall spaces between doors, windows, and similar places. Low plants will make up the front of the planting, uniting the higher 


$\overline{\text { SOUTHERN PLANTING FACTS }}$

\section{PLANTING THE HOME-GROUNDS, continued}

material at the back with the lawn in front. Additional color may be secured by placing annuals in Iittle groups here and there. The front line of planting can be irregular if space permits, or it may be straight. If the waII is good, it is often best to plant in groups with waIl spaces extending to the ground here and there, as a separation between one group and the next.

Nothing adds so much to the beauty of the grounds as a good lawn. The different grasses for lawn making are given on pages 39 and 40. These include the new Centipede Grass which gives every indication of being the best lawn grass yet found. It is adapted to a wide range of soils and conditions.

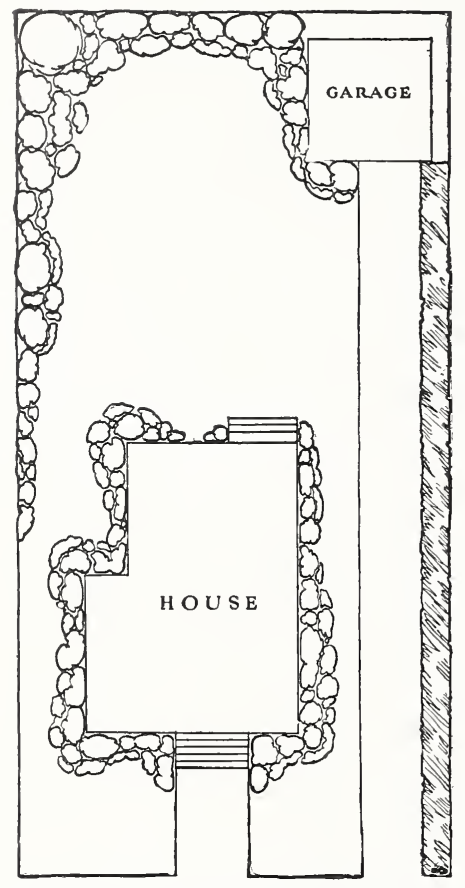

Plants on the city lot should be around boundaries and about foundations

What has been said of soil-preparation applies with equaI force to the making of the lawn. The foundation should be weII Iaid in a thoroughly and carefully prepared soil, weIl fertilized and carefully leveled or graded. The lawn grasses most commonly used in the Lower South are carpet, centipede, St. Augustine, and Bermuda grasses. These grasses are usually established with cuttings. Open the ground with a flat spade, insert the cutting and pack firmly with the foot. Water liberally and keep the weeds out until the grass makes a good cover. The secret of keeping a lawn in good shape is heavy fertilizing and watering. The lawn contrasting its uniform green with the different shades in the border, completes the picture, adding to and bringing out the beauties of the planting.

Generally, large masses of highly colored plants should be avoided, though they may be combined advantageously with more subdued colors. Deciduous shrubs are generally valuable for their flowers, but being bare of Ieaves in winter are sometimes not regarded favorably. These may be combined with evergreen sorts with pleasing results and there is nothing that quite takes the place of the early flowering shrubs. Many different species may be planted together or there may be clumps or groups of a single kind. Where bold or striking effects are desired, they can best be secured with large plantings of a single variety.

The materials, that is the plants to be used, should be carefully selected for the general sections of the country where they are to be planted and grown. Because the planter has seen a shrub grown in one part of the country often inclines him to plant it in another, where perhaps it is entirely out of place and cannot be grown at all. Frequently plantings are made with tender plants which are injured by frost and the garden is left bare and uninteresting. Climate, soil, moisture and exposure must all be taken into consideration. Some plants are adapted to shade while others are best suited to sunny locations. Certain plants grow weIl in shade but do not bloom satisfactorily while others bloom well only in shaded spots.

It may be desirable to have shrubs bloom at certain seasons and this can be done, in the garden, only by making a proper selection. These and many other requirements must be met if satisfactory results are to be secured. The lists which follow will be found of great assistance in making selections.

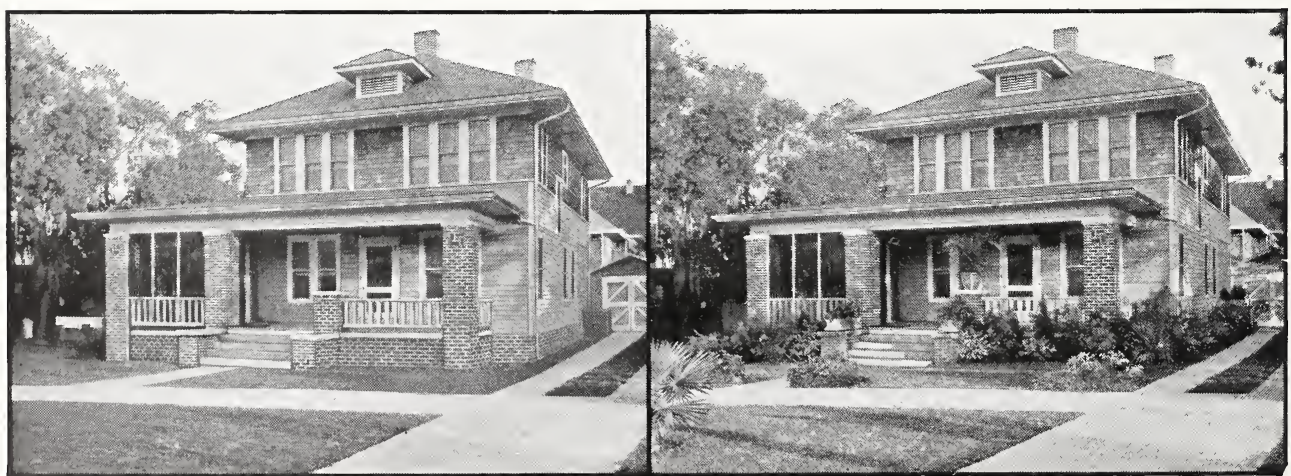

House foundations, before and after planting, help to make the difference between a house and a home 


\section{Plants for Foundation Plantings}

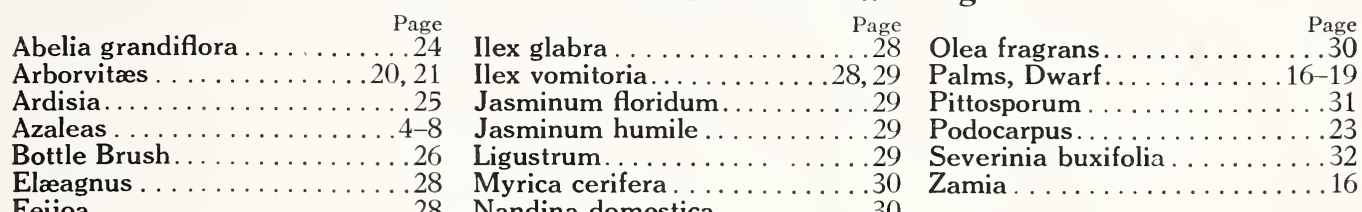

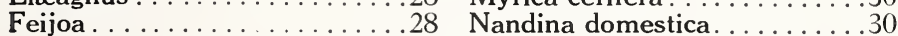

\section{Plants for Shady Situations}

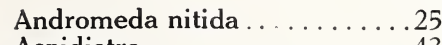

Aspidistra. . . . . . . . . . . . .43

Camellia japonica.........26

Camellia Thea.............33

Cestrum nocturnum . . . . . . . . 26

Cycas revoluta. . . . . . . . . . 16

Elæagnus . . . . . . . . . . . 28

English Ivy . . . . . . . . 40,41
Hydrangea..............................

Ilex glabra $\ldots \ldots \ldots \ldots \ldots \ldots \ldots \ldots \ldots 28,28$

Illicium anisatum . . . . . . . 34

Ligustrum. . . . . . . . . . . . 29

Liriope... . . . . . . . . . . . .44

Myrica cerifera . . . . . . . . . 30

Nandina domestica. . . . . . . . 30
Ophiopogon..............40

Palms ................ 16-19

Pittosporum ........... 31

Podocarpus..............23

Sansevieria.............. . 44

St. Augustine Grass . . . . . . . . . 40

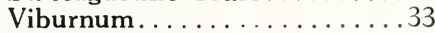

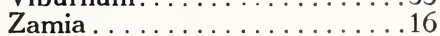

\section{Plants for Seaside Planting}

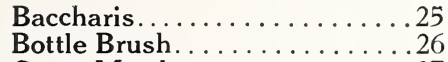

Crape Myrtle . . . . . . . . . . 27

Elæagnus . . . . . . . . . . 28

Guavas . . . . . . . . . . . . 78

Hibiscus . . . . . . . . . . . 28

Abelia grandiflora

Juniperus . . . . . . . . . . . 21-23

Lantana. . . . . . . . . . . . . . . . . . . 29

Liriope. . . . . . . . . . . . . .44

Myrica..................... 30

Oleander............................

Palms . . . . . . . . . . 16 19

\section{Plants for Hedges}

Arborvitæs . . . . . . . . 20, 21

Bamboos...................38

Bottle Brush.............26

Podocarpus..............23

Ilex glabra . . . . . . . . . . . 28
Pittosporum

Raphiolepis japonica............................

Schinus terebinthifolius. .......32

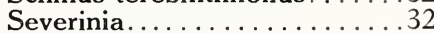

Yucca aloifolia............33

\section{Plants Flowering in Winter or Early Spring}

Acacia longifolia..........24 Dogwood.............35 Olea fragrans...........30

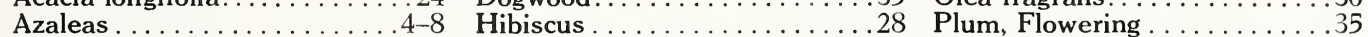

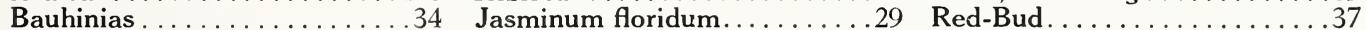

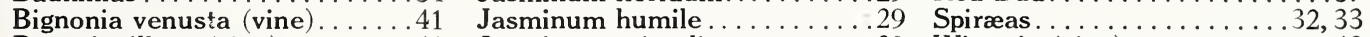

Bougainvilleas (vine) . .....41 Jasminum primulinum......29 Wistaria (vine) .........43

Buddleias ............26 Magnolia soulangeana nigra...30 Yellow Jessamine (vine) .....43

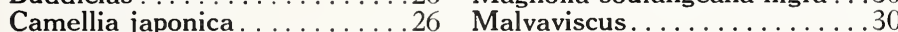

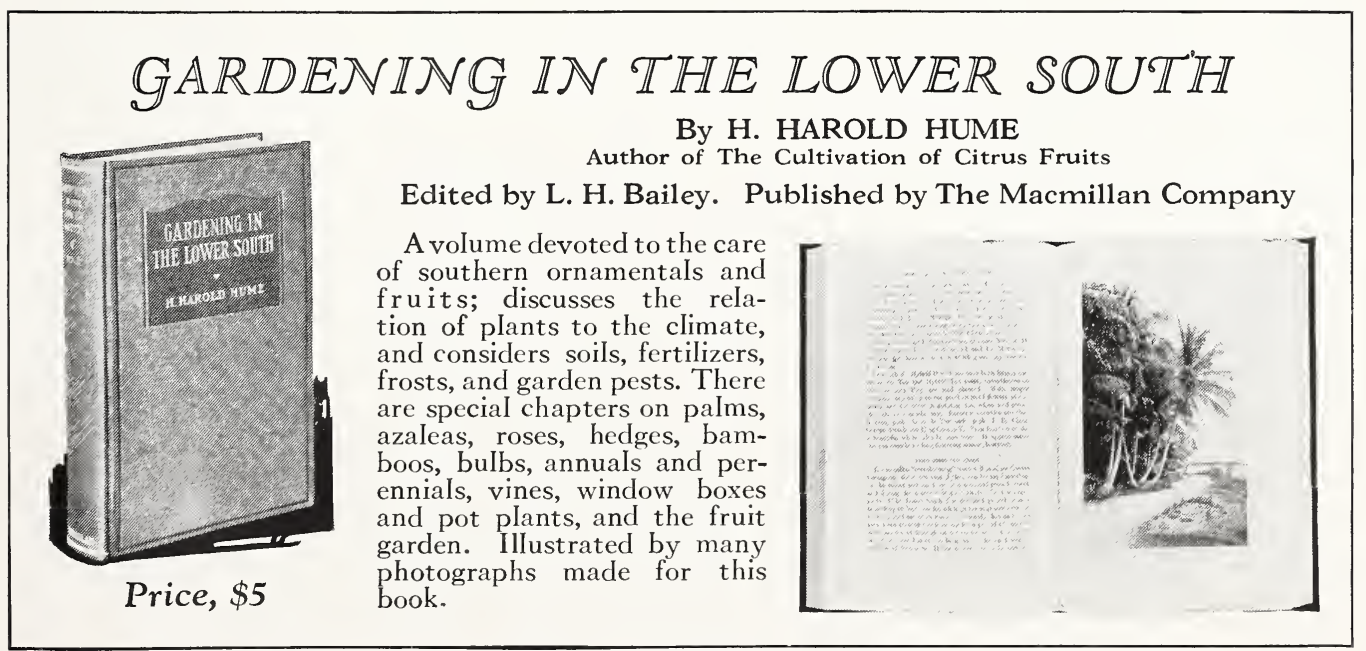




\section{Nerv and Unusual Planits}

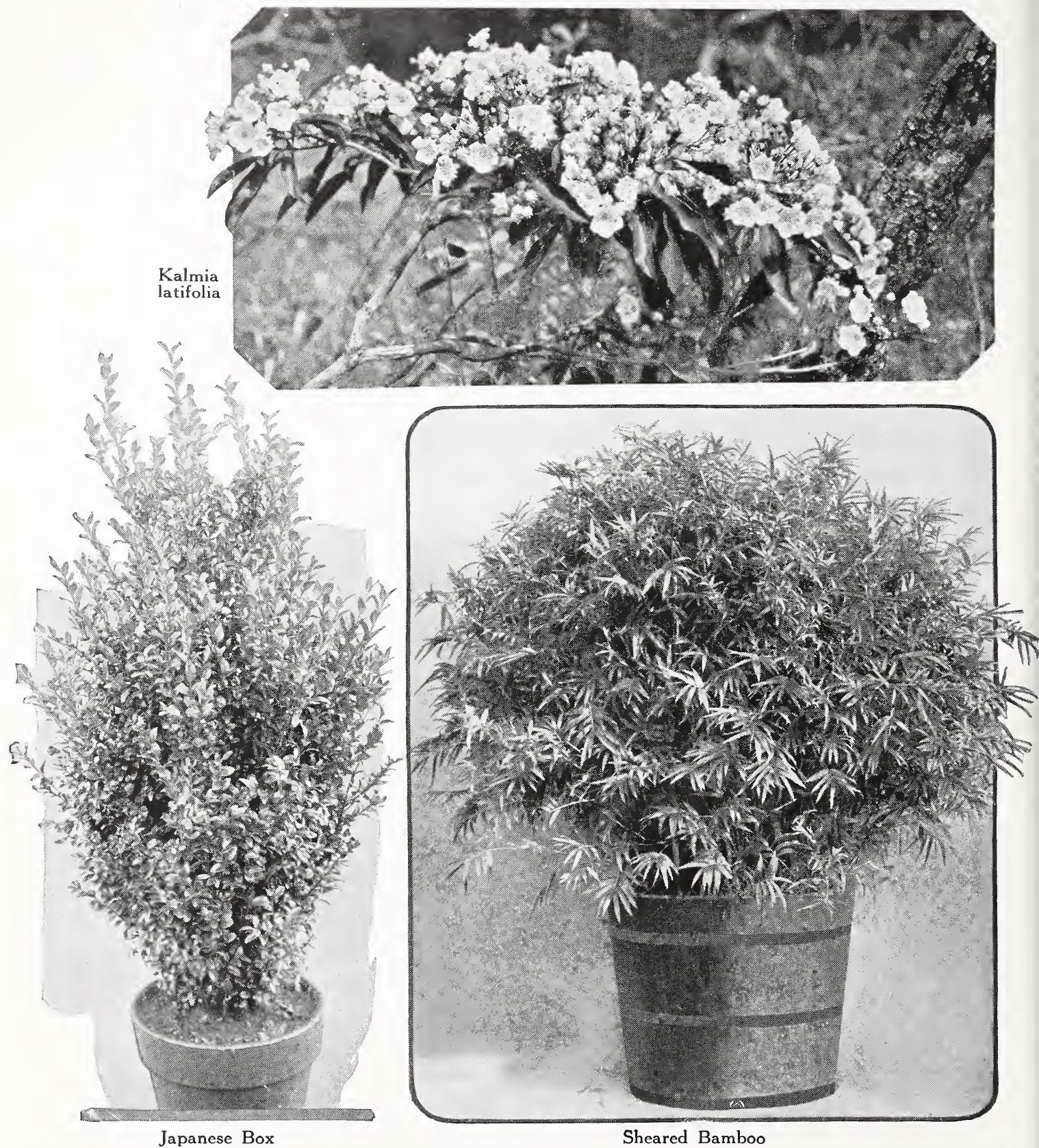

T $N$ these two pages, some plants not hitherto grown in quantity at Glen Saint Mary are offered. A few are uncommon and some of them are new or from new sources. The strain of mountain 1 IaureI (KaImia) for instance, is from the southernmost sources of this beautiful shrub. AII have been thoroughly tested over a period of years and are listed with confidence that they will give satisfaction to those who plant them.

\section{Bamboos}

Sheared, symmetrical specimens of compact habit, dense and beautiful. They may be used as individual lawn specimens or for growing in tubs. Properly spaced they make a finished hedge of rare beauty. 2 to $3 \mathrm{ft}$., $\$ 3.50$ each; 3 to $4 \mathrm{ft}$., \$5 each.

\section{Ilex integra}

An exceedingly handsome Holly with very large, smooth, glossy leaves with few spines. It is evergreen and has larger foliage than any other Holly. 18 to 24-in. plants from 6-in. pots, $\$ 1.50$ each. 
For Southern Gardens

\section{Japanese Box (Buxus japonica)}

Very dark evergreen shrubs for hedges, specimens, or tub use. Long-lived, handsome, and rapid-growing. 12 to 18 in., \$1 each; 18 to 24 in., $\$ 1.50$ each; 24 to $30 \mathrm{in} ., \$ 2$ each.

\section{Illicium floridanum}

A native, evergreen, aromatic shrub with large, shining foliage and rich, crimson-purple flowers with many petals. 2 to $3 \mathrm{ft}$., $\$ 1.50$ each; 3 to $4 \mathrm{ft}$., $\$ 2$ each; 4 to $5 \mathrm{ft}$., $\$ 2.50$ each.

\section{Ligustrum lucidum aureo-marginatum}

A brilliantly colored, yellow-edged variety of the handsome, glossy Privet which is very fine for specimen use either in the open or in tubs. 2 to $3 \mathrm{ft}$., $\$ 2.50$ each; 3 to $4 \mathrm{ft}$., $\$ 3.50$ each; 4 to $5 \mathrm{ft}$., $\$ 4.50$ each.

\section{Ligustrum coriaceum}

A very slow-growing evergreen with dense, dark green, twisted or curled foliage. Suitable for specimens and dense masses. 12 to 18 in., \$2 each; 18 to 24 in., \$2.25 each.

\section{Ligustrum japonicum}

A vigorous, enduring form of the Japanese Privet, with hard, glossy, evergreen leaves. Excellent for screens, large masses, and as specimen plants. 2 to $3 \mathrm{ft}$., $\$ 1.75$ each; 3 to $4 \mathrm{ft}$., \$2 each; 4 to $5 \mathrm{ft}$., $\$ 2.50$ each.

\section{Kalmia latifolia}

This is the far-famed Mountain Laurel of the eastern United States. It has beautiful glossy green foliage and clusters of pinkish white blossoms in early spring. Our strain comes from the southernmost limits of the species. Adapted to all of northern Florida and northward. 18 to 24 in., \$1.50 each; 24 to 30 in., $\$ 1.75$ each.

\section{Ligustrum lucidum nobile}

A very erect, taII, evergreen shrub, useful for giving height and stability to massed plantings. Makes handsome specimens. 2 to $3 \mathrm{ft}$., $\$ 1.75$ each; 3 to $4 \mathrm{ft}$., $\$ 2$ each; 4 to $5 \mathrm{ft}$., $\$ 2.50$ each.

\section{Photinia serrulata}

This is a remarkably handsome object in summer, with fine, glossy foliage and large clusters of white flowers. It is also very spectacular in winter when it is covered with clusters of scarlet fruits shining against the dark green leaves. Good plants, 18 to 24 in., from 6-inch pots, $\$ 1.25$ each.

\section{Viburnum odoratissimum}

An erect shrub of distinct habit, with Iarge, evergreen Icaves. In early spring it bears clusters of waxen, richly fragrant flowers which are followed by red and black berries. Sheared specimen, 2 to $3 \mathrm{ft}$., $\$ 3$ each; 3 to $4 \mathrm{ft}$., $\$ 4$ each.

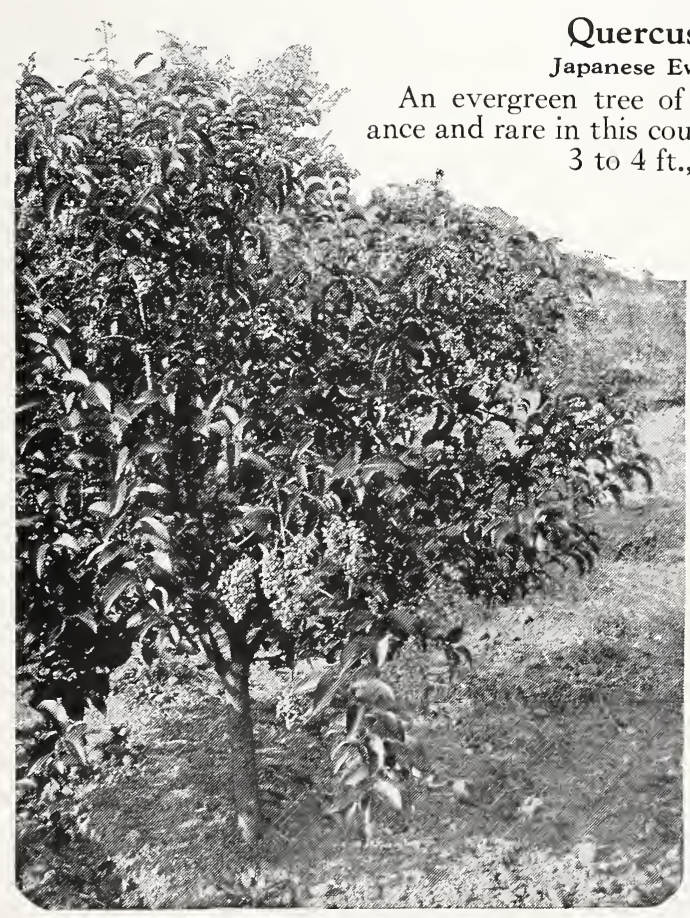

Ligustrum japonicum

\section{Quercus glabra}

very handsome appear-
vernon $\$ 5$ each. 


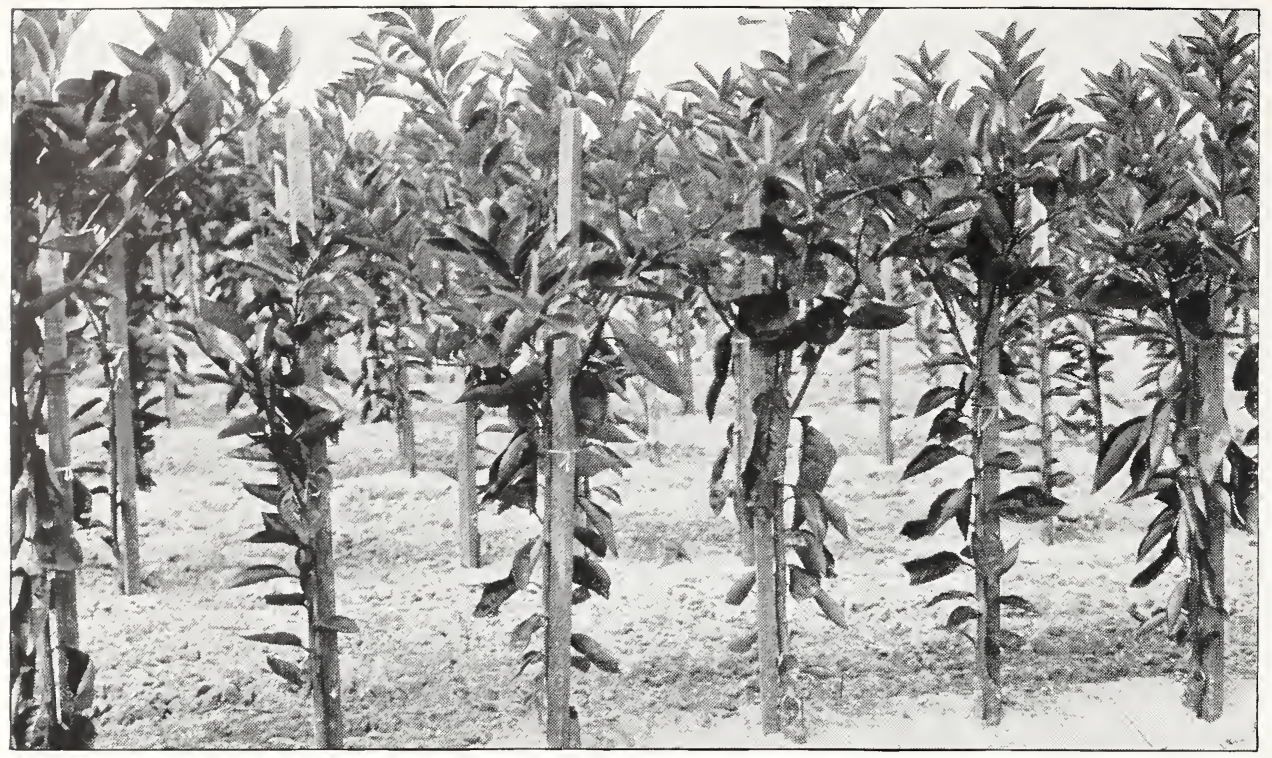

Citrus trees ready to dig for the customer

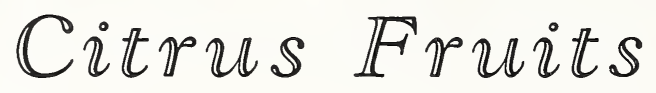

T

THE GLEN SAINT MARY NURSERIES COMPANY has grown more citrus trees than any other nursery in the world for a great many years. While we produce other nursery trees as well, the growing of citrus trees has always been the paramount interest of our nursery business. Words like "Iargest" or "biggest" do not mean much to a prospective buyer until he considers that the reason for this largeness is the continued and ever-increasing demand for stock that has absolutely made good with our customers in every sense.

We know the comparative value of different sorts because we are growing them in our test orchards. In these orchards the largest-known collection of citrus fruits is to be found. At the meeting of the American Pomological Society in Washington, in November, 1913, we exhibited eighty-three varieties of citrus fruits. No such collection of citrus fruits grown by one firm was ever brought together before. Not aII of these varieties are offered in our lists; only the best, determined by actual test, are propagated.

Our varieties are selected strains, with a straight-line history going back to an individual tree of known merit. Care is taken in propagation to select weIl-developed buds from trees of authentic parentage, making sure that the young trees are true to name-quality trees in every particular. When the trees are sold, the roots of one-year trees are three to five years old.

Citrus trees can be grown on roots of any member of the whole citrus family. We have tried a great many of them. Most of them, for one cause or another, are not adapted for citrus fruit culture under general conditions. We have found that practically aII requirements for success under different climatic and soil conditions can be met with Sour Orange, Rough Lemon, or Citrus trifoliata stocks. SuccessfuI, heavy-bearing, beautifuI groves are produced from trees on aII of these stocks. But no one of them will meet all conditions. It is largely a matter of soil, location and climatic conditions.

ROUGH LEMON. Rough Lemon is the thriftiest and induces a vigorous growth of top. On account of its wide-spreading root system, it is the best stock for light sandy soils, such 'as are found on the lower East Coast and in the high rolling regions of Polk, Orange and Lake Counties to be quite immune from frosts, and to this type of soil the Rough Lemon stock is best suited.

SOUR ORANGE. A deep-rooted stock, adapted to the heavier soils such as good flat woods land, hammock and muck, where it produces fine, vigorous trees. For the production of high-quality, Iatekeeping fruit it is unsurpassed.

CITRUS TRIFOLIATA. Varieties budded on this stock are made hardier because of its dormant and hardy character, and the fruit is of exceedingly fine quality, ripening two to three weeks earlier than on other stocks.

For the Satsuma Orange, it is the onIy stock to use, because of its influence on the quality of the fruit and the fruitfuiness and hardiness of the tree. It is adapted to planting on alluvial Iands, clay lands, soils underlaid with clay, and those which naturally contain plenty of moisture or to which water can be applied by irrigation. It should not be planted on high, dry, sandy lands lacking moisture. On such soils it is a failure. 


\section{SOUTHERN PLANTING FACTS}

\section{ORANGES}

Since the very earliest days, the Orange has attracted the attention of fruit-growers and fruitconsumers. Today it is one of America's most important fruit crops and based upon it an enormous industry has been built up, and in addition to its importance in commerce, it has lost none of the charm that has come down to us from ages past. From time to time during the period which has brought the Orange to its present important place in industrial development, it has been prophesied that too many trees were being planted, that the fruit supply would so outrun the demand that producers would not receive satisfactory returns from their crops. In moments of pessimism, many have been guilty of such predictions. Yet, they have not come true when the crop has been properly distributed and marketed, and, looking at the matter broadly, it is a safe venture to say that such a condition will never come about.

Our list covers the market season of Florida fruit. The list of standard varieties of Oranges which we are propagating for our customers cannot be improved upon, and when a planter has decided upon the season at which he desires to market his crop, the question of varieties to plant is easily settled.

With the establishment of our nurseries in 1882, the propagation of the Orange was undertaken. We have seen many varieties come and go. For over forty years we have been growing citrus nursery stock. Naturally, during these years we have learned much, and our work today is backed by a knowIedge of how to grow good Orange trees that is of the utmost value to our customers.

\section{Hamlin Orange}

Throughout the history of commercial citrus culture in Florida, there has been a constant effort to find a high-quality, early, round Orange-one having early maturity combined with good flavor and attractive appearance, without the shortcomings of so many early Oranges. An Orange combining aIl of these good qualities has been in existence for more than forty years.

In 1879, an 8-acre Orange grove was planted by Isaac Stone near Glenwood, Volusia County, Fla., for Mrs. Mary H. Payne, the mother of Mrs. A. G. Hamlin. Later, this grove came into the possession of A. G. Hamlin, formerly of DeLand, now of Tavares, Fla. A mixed lot of trees for this planting was procured from three small nurseries belonging respectively to Isaac Stone, Benjamin Cook, and Fred E. Norris.

In 1883, when Mr. Hamlin took up his residence in Florida, this grove was just beginning to bear. In the winter of 1884 his attention was attracted to the fruit on a tree in the grove which was entirely different from that borne by others in early ripening, thinness of skin, and height of color. Mr. Hamlin top-worked other trees in the grove to this variety. By 1895 he was selling from 300 to 500 boxes yearly, mostly in the DeLand market. It was given preference over all other varieties of its season. Because it was such a favorite with Mr. Hamlin, it was commonly referred to as "Hamlin's Favorite."

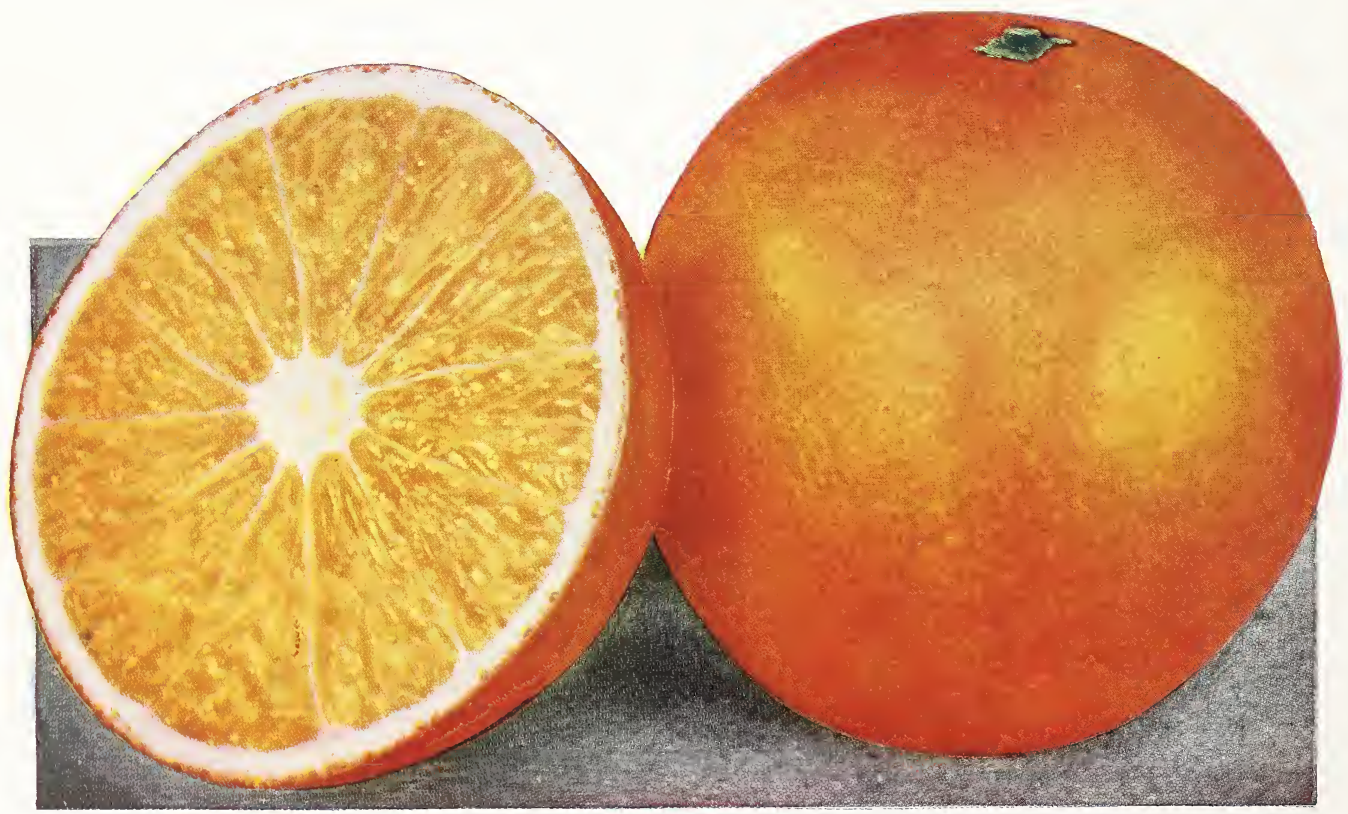

Hamlin Orange 


\section{Glen Saint Mary Nurseries Co. Glen Saint Mary, Florida}

\section{ORANGES, continued}

Prior to the freeze of 1894-95, Mr. Hamlin seriously considered forming a Iarge nursery company to extensively propagate and distribute this fine Orange. The freeze destroyed all of his trees with the exception of three, which happened to be partially banked with hay and trash piled

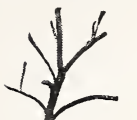
up around them. From these trees so saved, Mr. Hamlin again started to propagate the variety. Eventually he budded about 15,000 trees and sold them under the name of Hamlin's Improved Pineapple. Circulars were distributed and it was written up and described in the state press.

Mr. H. A. Wright, who was to have had charge of the proposed large nursery, budded two trees in his grove at Glenwood. One of these was killed in a Iater cold, but the other tree survived and still stands near a barn on the old Wright place. It was from this tree that we secured budwood for our first propagation of this variety.

In December, 1913, it was brought to our attention again by Mr. F. W. Bredow, of Glenwood, Fla., a resident there for over forty years. After the freeze of $1895 \mathrm{Mr}$. Bredow secured budwood of the variety and was propagating and selling it under the name of Norris Early Seedless. There is, however, no proof that this Orange originated with Mr. Norris. It could have come from any one of the three nurseries from which the trees were secured for the Payne grove planting in 1879. It appears that it was first recognized as a distinct variety in this grove.

We visited the oId tree on the Wright place and secured a small quantity of budwood from it. With this we top-worked several old trees and a number of years ago planted a 10 -acre grove of this variety on Sour Orange stock.

We have fruited and tested in our own test-grove of over eighty varieties, most of the round Oranges which have been offered the planting public. We have had other varieties under observation for many years, but until this Orange was brought to our attention we never knew a very early round Orange that did not have some serious drawback. Some are too large, others too smaII, still others misshapen. Several early sorts have thick, coarse, pebbly rind; others do not color weIl, and some are almost tasteless under most cultural conditions.

Hamlin is an ideaI early Orange. It matures the later part of September and early October, somewhat earlier in the northern citrus belt than in the southern. In Polk County, it will pass the legal acid test of eight to one the first week in October, and it can be shipped at that time. It shows very good color as soon as it is mature enough to ship.

In color, it is a clear, golden yellow, tinged with deep orange-red, which becomes more pronounced if the fruit is allowed to hang on the trees until full maturity. The texture of the skin is wonderful. It has the smoothest rind of any round Orange known to us and it is a distinctly fancy fruit.

Its flesh is melting, very juicy, with real delicious Orange flavor at its earliest maturity. It is practically seedless-most fruits have no seeds at all, but some contain from one to three seeds. The sizes are those for which the market pays the highest prices. Several hundred boxes from our own trees, and shipments made by others which have come under our observation, have practically all run 176's and 216's, with, of course, a very few 150's and 250's. It is a medium-sized Orange, and over a period of years it has proved to be an excellent shipper. Its normal season is October 1 to 10 , but it can be held sixty days later without deterioration. It should not be carried on the trees later than January 1 in most seasons.

\section{King Orange}

The King Orange is the Iatest-maturing of the Mandarin (sometimes called the Kid-glove) group. It is ready for marketing in March and April. The fruit is of large size, flattened, deep orange in color, roughened and pitted on the surface, with a rather thick rind. The flesh is deep orange in color, quality excellent, with a sprightly, agreeable flavor in which sweet and subacid are weIl blended. The tree is an upright grower, with very dark green, shiny foliage. It is a very prolific sort and this, together with its lateripening season and high quality of fruit, have combined to make it a very profitable variety. It always commands a high price in the markets. In any mixed orchard it is well worth planting, and it has a place in every home grove. This side of citrus fruit culture is very often lost sight of. Our whole attention is so often given solely to our commercial work that we lose sight of fruits to be grown for home use.

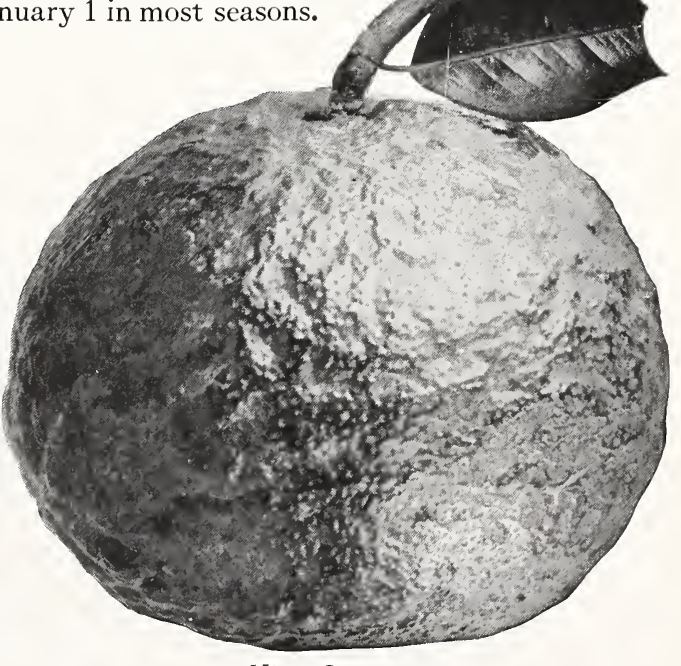

King Orange 


\section{Lue Gim Gong Orange}

The Lue Gim Gong Orange is an established commercial success. Based on reports from our customers, and upon the behavior of bearing trees in our own groves, we give the following information: In size, the fruit is large, packing 126 to 176 per box; in form oblong, carrying its full diameter well down to the rounded base. The color is a deep orange-red; skin smooth; sections ten or eleven in number; flesh deep orange, very juicy, and free from rag. The flavor is a rich blending of sweet and subacid and, when fully ripe, of delicious, unsurpassed quality. It is nearly or quite seedless. The fruit is a good keeper and fine shipper and in itself is very hardy and resistant to cold.

Lue Gim Gong trees are hardy, thrifty growers. In our own groves and nurseries we have observed during several cold snaps that trees of this variety invariably suffer less injury than any other variety of round or sweet Orange. With us there is no question but that it is the hardiest of the sweet Orange group. This statement is amply borne out by the observations of many growers under widely different conditions.

The tree is a good bearer, the equal, if not the superior of any late Orange in this particular. It is a regular bearer, and this is very unusual, for in the case of most late varieties, if the Oranges are allowed to hang on the trees until late in the season, the crop following will be light. It produces a low, well-rounded head, spreading rather than high and upright.

The fruit is edible in March and April, but is then too acid for most tastes. It begins to ripen in June, and from then on is delicious. It will hang on the trees for months, but for all practical purposes would be marketed as a remarkably late Orange for one year, say in June or July, or as an exceptionally early one for the next season, in September or October. From our own groves, Lue Gim Gong has brought us splendid prices and we recommend it for commercial planting.

\section{Parson Brown Orange}

This has been for many years considered the leading early round Orange of Florida. It is not all that might be desired but has been, up to now, the best early Orange grown on a commercial scale. It always brings good returns to the grower as it is shipped under its own name and is one of the earliest which will stand the Government acid test.

Our strain of Parson Brown goes straight back to the original source, and we have been growing it in orchard and nursery for more than twenty-eight years. We have selected and re-selected it from bearing trees until we know there is no better Parson Brown than the old Carney Parson Brown, Glen Saint Mary selected and grown. It was introduced about 1878 by Capt. J. L. Carney, of Lake Weir, Florida. The fruit is medium to large size, of fair quality, and is ready to market in early November or sometimes late October.

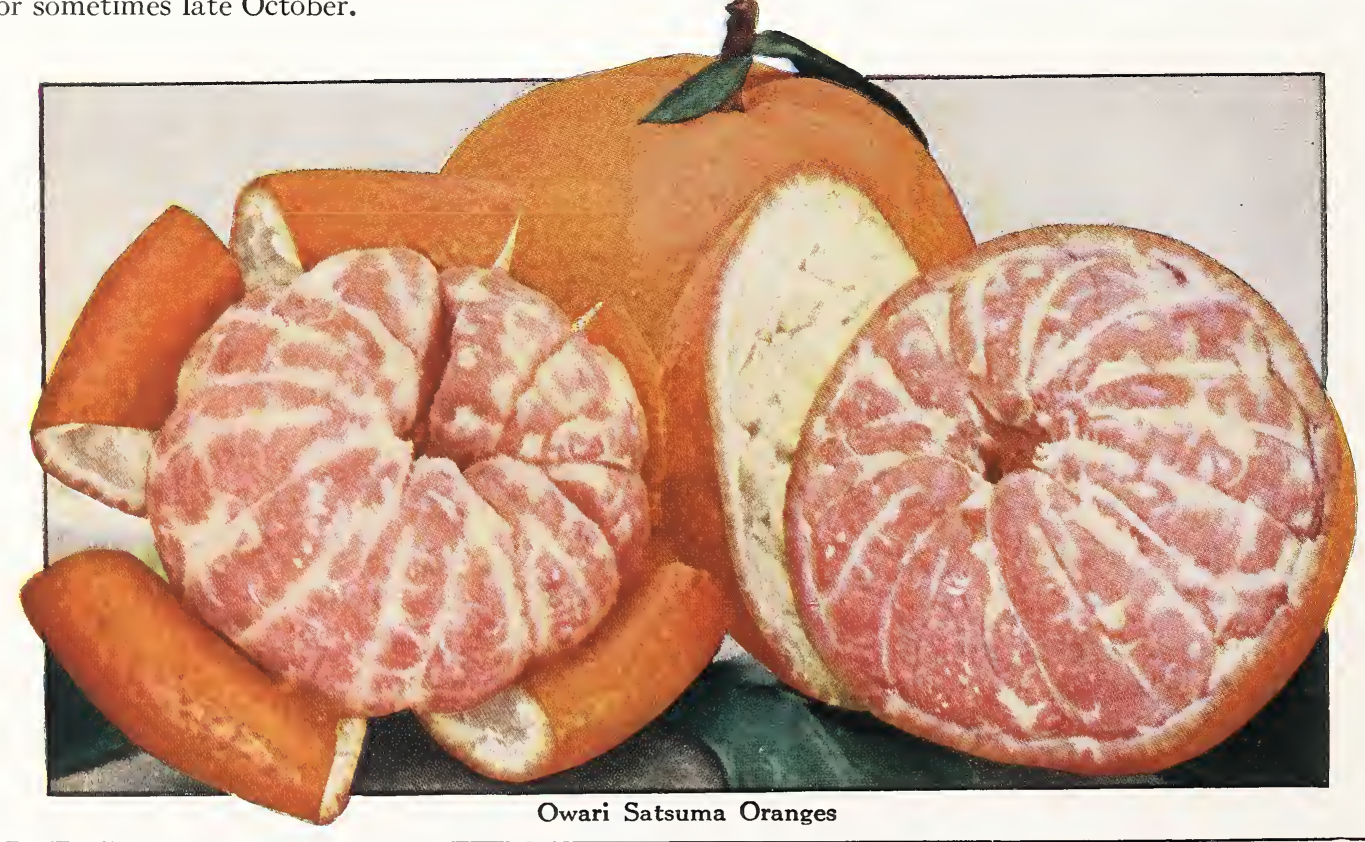




\section{Glen Saint Mary Nurseries Co. Glen Saint Mary, Florida}

\section{Owari Satsuma Orange}

For many years it was believed that there was but one Satsuma Orange. The investigations of Dr. T. Tanaka, however, have shown that in Japan there are at least a half dozen weII-marked varieties of Satsuma, with still others showing minor distinctions. A careful investigation of Satsuma orchards has been made in America by Dr. Tanaka and Mr. Leo. B. Scott, of the United States Department of Agriculture. They found that three strains of Satsuma have been unknowingly mixed together, propagated, sold, and planted. The result in the bearing orchards is most unsatisfactory, as the resulting crops are not uniform in size, quality, or time of ripening.

When the propagation of Satsumas was undertaken by the Glen Saint Mary Nurseries (trees were first offered for sale in 1888), but one single introduction was made. The propagating material of this strain came from Maj. O. P. Rooks, Fruitland Park, Fla. To this single introduction, all our subsequent propagations trace back. Orchards planted with Glen Saint Mary trees throughout the GuIf Coast country became noted for the fine, large, uniform, early-maturing crops of fruit they produced. An investigation made by Dr. Tanaka and Mr. Scott has shown that our trees in orchard and nursery consist of a pure strain-Owari Satsuma. This is the variety most commonly grown in Japan, where it has practicaIly supplanted other strains. Through aII these years - past forty years to be exactthis is the variety we have furnished our customers. This is so as the direct result of our policy of line propagation, beginning with a definite specimen of known worth. The fruits of Owari Satsuma are large, flattened, depressed at both stem and blossom end, deep orange in color, with thin smooth rind, which may be stripped from the puIp with the fingers without breaking the sections into which the fruit is divided (see illustration), and nearly or quite seedless. No citrus fruit that we know of surpasses a well-grown, well-ripened fruit of Owari Satsuma from our orchards. Trees of this strain are thornless, prolific, vigorous, rather upright growers. For years we have marketed our crop during October and early November, though sometimes we have shipped in September. Owari Satsuma is an extremely hardy tree, having gone through 15 degrees $\mathrm{Fahr}$. without injury, and its natural hardiness is increased by budding on Citcus trifoliata stock. This is the only stock adapted to it, the only one on which we grow it. Young trees are heavy bearers, and under proper conditions an orchard of this variety brings early returns on the investment. It is particularly adapted to west Florida, southern Georgia, Alabama, Mississippi, Louisiana, and the GuIf Coast country of Texas. In this section Owari Satsuma is a high-class, profitable orchard fruit.

\section{Pineapple Orange}

The fame of this variety was established many years ago, and of all the Oranges which have originated in Florida it has been most largely planted. It often happens that varieties in favor at one time are later supplanted by others, but this has not been the case with Pineapple. No orchard planting today is contemplated without considering this variety, and we venture to say that so Iong as Oranges are grown in Florida the Pineapple Orange will make up a generous part of the output. It originated

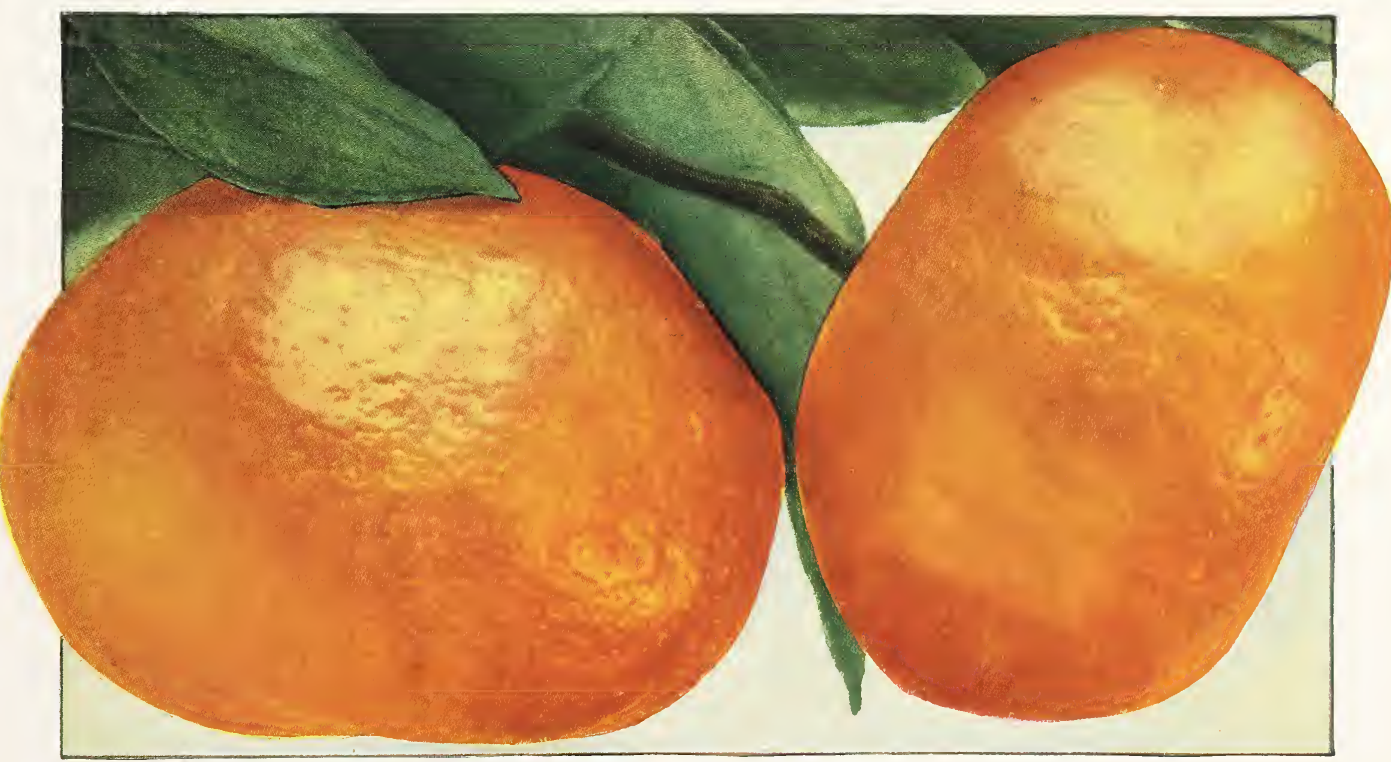

Tangerine Oranges. See page 56 
PINEAPPLE ORANGE, continued

in the heart of the old citrus belt of Florida, near Citra, in the grove of Dr. James B. Owens. Because of its peculiarly fine flavor and its fancied resemblance in flavor to a pineapple, it was so named. The fruit was frrst marketed in quantity by Bishop, Hoyt \& Co. It soon established a reputation, a reputation it has maintained and increased from year to year.

The fruit is of good size, a deeper, richer red in color than any other round Orange we know. Of course, it has to become well ripened before its full color develops, and in some localities it takes on higher color than in others. In quality it is unsurpassed, its flavor being a rich blending of sweet and subacid peculiar to the variety. It not only resembles the pineapple in taste but also in odor. Pineapple Orange trees bear well. For its season, January to February, it has no superior.

\section{Dancy Tangerine Orange}

This Orange, a "kid-glove" Orange by the way, is so often referred to as a fancy fruit that its reaI value as a straight money-making variety is often lost sight of. Plantings of Tangerines have proved to be very profitable, and quantities now produced are always marketed at good profit. Moreover, it ripens and is ready for market when its extremely high color lends most value to its sale.

The tree is compactly headed, dense, and rather upright, but tending to spread as it grows older, the head being opened by the weight of heavy crops of fruit. It is a wonderfully prolific variety. The fruit is flat, of medium size, with very smooth rind and very high color; a brilliant deep orangered, almost tomato-red, sets it in a distinct class from all other citrus fruits. Like Satsuma and King, the skin is very easily removed and the sections readily separated without breaking the juice sacs or soiling the fingers. The original tree was raised by the late Col. Francis L. Dancy, Buena Vista, Florida, and propagation was started about 1871. For the grower who desires to produce a high-grade fruit that is just a little out of the ordinary, Dancy Tangerine is a safe variety to plant.

\section{The Temple Orange}

In August, 1924, we acquired the nursery interests of the Buckeye Nurseries, Inc., Tampa, Fla. These were the largest nurseries in the world devoted exclusively to the growing of citrus trees. For many years the late Myron E. Gillett and his son, D. C. Gillett, occupied a foremost position in the citrus nursery business of Florida. Among their achievements was the introduction of the Temple Orange. In the transfer above mentioned the Temple copyright and franchise came into our possession and we have the sole right to propagate and distribute trees of this variety.

Since the introduction of the Temple Orange in 1917, we have had it under close observation and have investigated its behavior and characteristics from every angle. We have propagated it in the nursery, have planted it in our own groves, brought it into bearing and have watched with keen interest its performance in plantings of many others.

We believe that, propagated on the right stock and the trees properly handled on any good citrus soil, Temple is one of the finest Oranges that has ever been brought into cultivation. We have very complete knowledge of the behavior of Temple on three stocks, Sour Orange, Rough Lemon, and Citcus trifoliata. It can be planted on lands to which these stocks are adapted with every assurance of success, if properly grown. See page 50 for information on stocks.

To produce high-quality fruit of this variety, the top or wood growth of the tree must not be too rapid. Rather must it be somewhat slower than that of other varieties, and in no case should it be unduly forced in growth. This can, of course, be controlled by properly selected root-stocks, by reducing the amount of cultivation given and fertilizer applied. It is an extremely precocious variety and bears early and heavily.

\section{The Horticultural Description of the Temple Orange Follows:}

Form oblate, tapering slightly to the stem; size medium to large, about $21 / 2 \times 31 / 8$ inches; color deep orange-red; apex broad, shallow depression sometimes navel marked; stem end of fruit tapering and usually creased; calyx small; stem slender; skin smooth or pebbled, leathery, thin, separating easily from the pulp, in this particular intermediate between Tangerine and round oranges; oil-cells spherical or slightly flattened; sections ten to twelve with very thin partitions; flesh orange in color, melting, free from rag, very juicy; juice sacs slender, spindle shaped and of medium size; acidity and sweetness well blended; flavor spicy, rich, vinous and very characteristiz; seeds, about twenty, small to medium in size with green cotyledons; season January to April. There is every indication that this fruit is a hybrid between a sweet orange and some variety of the Mandarin group. The flavor is delicious and quite different from that of any other Orange.

More and more satisfactory financial returns from the production of citrus fruits are dependent upon the growing of strictly high-grade fruit. From every standpoint the Temple Orange is a fancy fruit. With its beautiful appearance and fine quality, it will, when the markets become acquainted with it, be in great demand. Temples are marketed during the latter part of the Tangerine season and later. It can be sold as an Orange of the so-called "Kid Glove" Orange group, for which there is a heavy demand and for which excellent prices are always obtained. The inclusion of Temple in the setting of a grove will yield a very profitable return for the planter. 


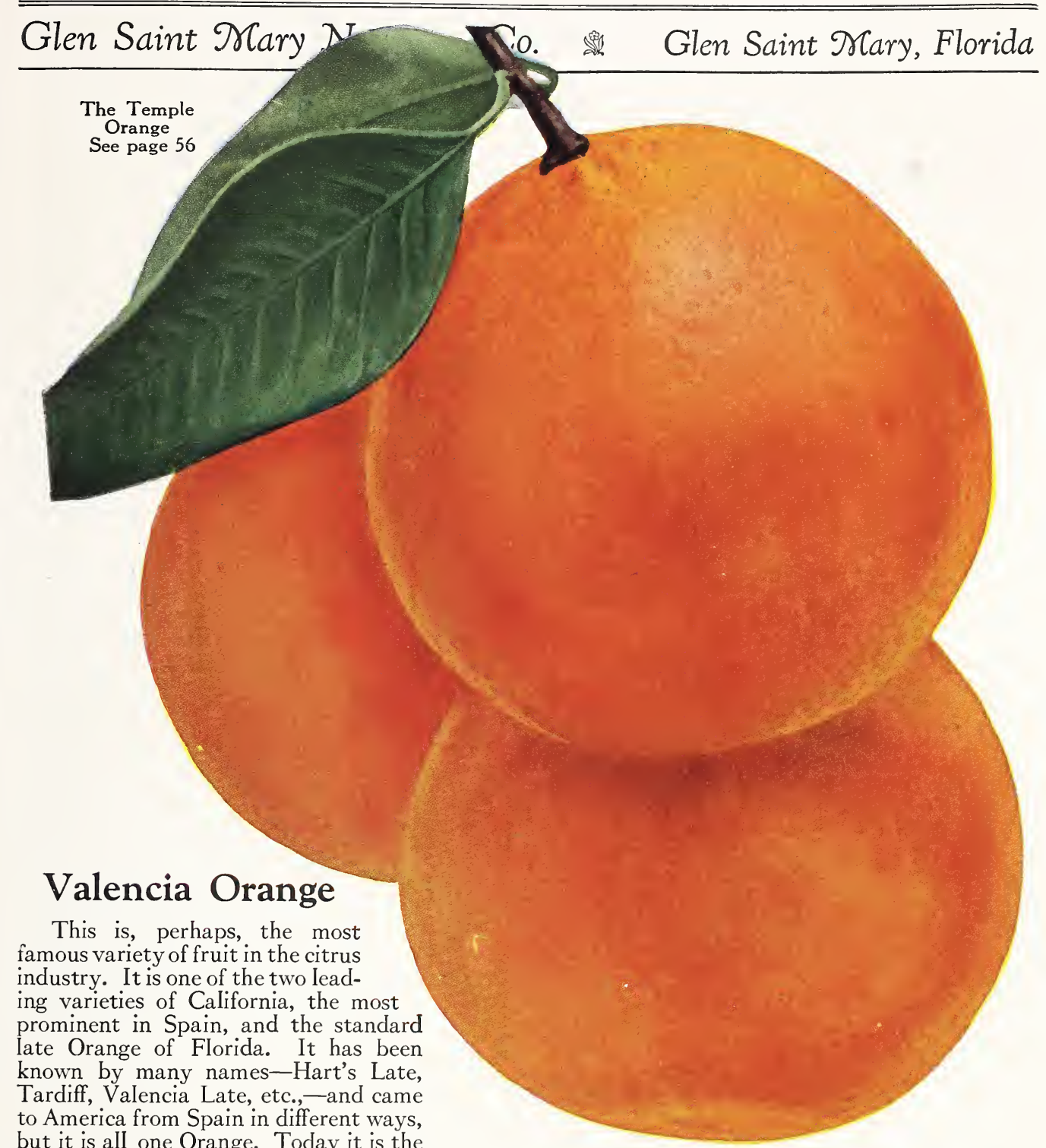
but it is all one Orange. Today it is the most widely grown late Orange and the only one to be considered for its season-March to June. Owing to the fact that it is practically the only Orange on the market at this time, the Valencia commands a fine price, and, consequently, plantings of this variety are very profitable. A survey of prices received for Valencias over a long period of years shows that the returns have been most uniformly good. In years of short crops, or held very late, instances of growers receiving as high as from $\$ 7$ to $\$ 9$ per box, net, on the trees, are not uncommon. The general average would be in the neighborhood of \$4. In planting Valencia, a locality should be selected that is reasonably free from frost or damaging cold, as the fruit remains on the trees throughout the winter months.

The tree is a strong grower and comes into bearing early. It blooms at the same period as other varieties - usually in February - but matures its fruit slowly, and it is not until over a year later, the following March, that it is ripe enough to ship. However, the trees put out bloom and set a normal crop while carrying the current or old one. It can be heId on the trees until late May or early June, thus allowing for a wide marketing period. During the spring months, bearing Valencia trees, while they are carrying a mature crop, should not be forced into too active or Iush growth. If this is done there will be a tendency for the fruit to turn green and dry out at the stem end. The heaviest application of fertilizer should be put on in June after the old crop is removed, and then again in the faIl.

Valencia fruit is of medium size, of good color, with thin skin and firm deep orange flesh. It is practically seedless, containing only a very few seeds, is very juicy and, in quality, delicious. It is also a splendid shipper, is marketed under the name Valencia, and is most favorably received in all citrus markets. 


\section{$\overline{S O U T H E R \mathcal{N}}$ PLANTING FACTS}

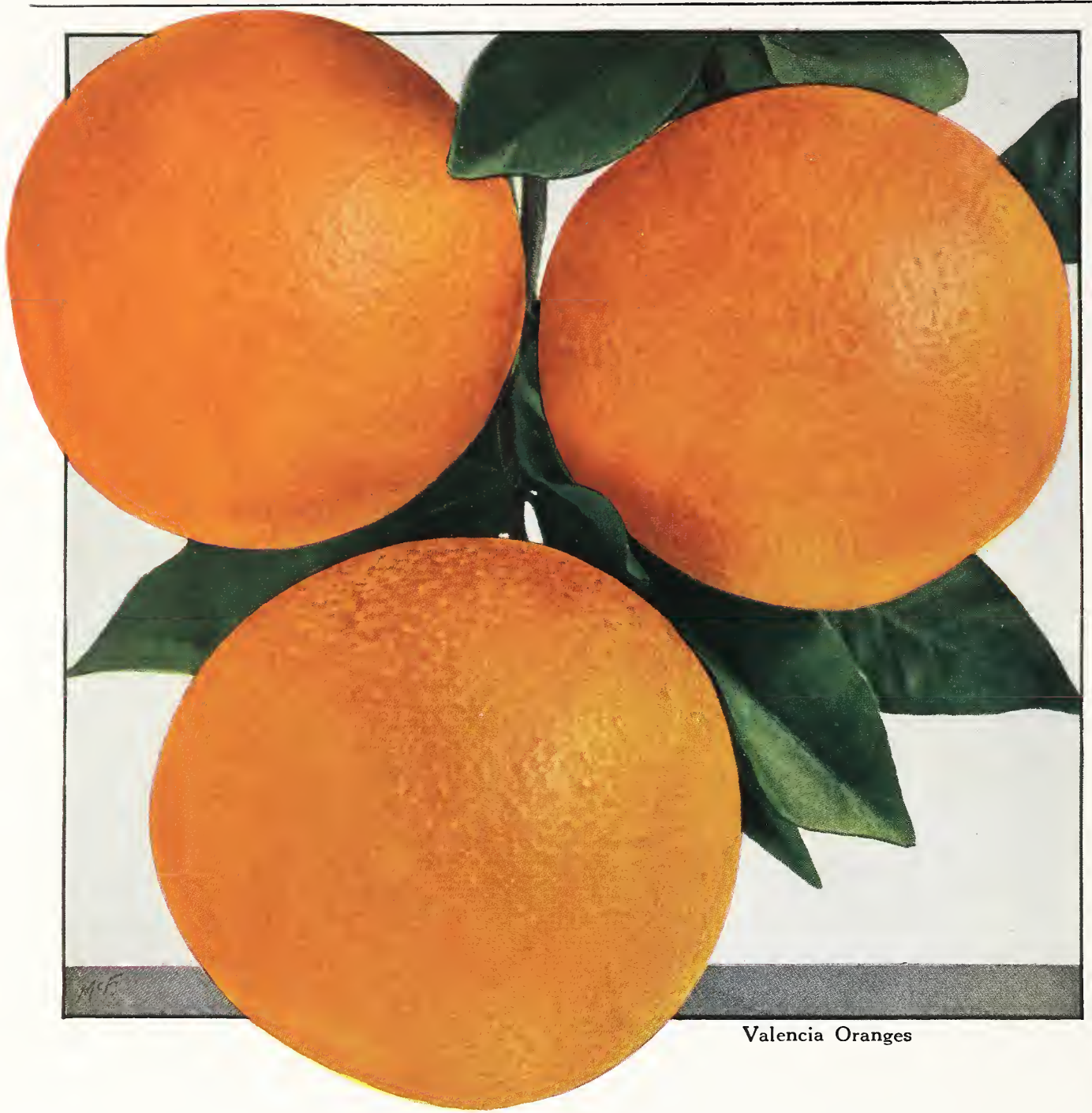

Many years ago we tested out a number of strains of Valencia from both California and Florida. Most of them showed only slight variation in fruit or tree characteristics. However, we selected the one which showed the best tree-growth, bore the most desirable market sizes uniformly, produced the finest fruit, and proved to be the most prolific and regular bearer. This strain was from one of the greatest Valencia orchards in California. There are many strains of Valencia trees on the market, but we firmly believe that we offer our customers the best Valencia in existence.

\section{Washington Navel Orange}

In many ways this is the most remarkable Orange grown today. It is the Orange which standardized the output of California citrus orchards, and perhaps it is not too much to say that this single variety has been in a large measure responsible for citrus development in that state. Florida growers are not, or should not be, interested in it, because it will not yield enough fruit to pay for planting it. Fruit can be secured from trees budded on Rough Lemon or Citrus trifoliata stocks, but even then it has no place in a commercial planting. We grow it for our trade in other countries. The fruit carries its own trade-mark - the navel marking on the blossom end of the fruit. In size, it is large, the pulp meaty, not so tender and juicy as some of the finer varieties, but still a very fine Orange. It is an excellent shipper, and its high color and seedlessness are other important points in its favor as a market fruit. It can be grown successfully on heavy soils, on Sour Orange stock, in irrigated districts, and for such localities it is highly recommended. Introduced from Brazil, in 1870, it was exhibited at Riverside, Calif., in 1879 and shortly after that its propagation and planting were undertaken. 


\section{Glen Saint Mary Nurseries Co. Glen Saint Mary, Florida}

\section{KUMQUATS}

The Kumquat is the smallest of the citrus fruits in general cultivation in this country. Usually the plants are called bushes, for they do not make trees. The plant grows to a height of 10 to 12 feet, with a spread of branches about equal to its height. The bright, dark green leaves and deep golden yellow fruits make a very pleasing combination of color. The flowers are small, sweet-scented, and appear in June on the shoots produced earlier in the same season. The fruit ripens during the fall and winter, beginning with the month of November. As an ornamental alone, it is not surpassed by any other evergreen shrub with which we are acquainted.

In point of hardiness, the Kumquat ranks with the Satsuma orange. It will withstand temperatures of 15 degrees Fahr. and even lower.

We are the largest growers and shippers of this fruit in the country, having marketed from four to six hundred bushels of fruit annually for several years past. The crop has netted from $\$ 2.50$ to $\$ 3.25$ per bushel, sometimes selling as high as $\$ 6$ to $\$ 10$ per bushel. We have found it a profitable fruit to grow; as the trees yield well and can be planted close together. When gathering the crop we always cut the fruit from the trees with twigs and leaves attached, and pack a goodly proportion of leaves with the fruit. They are packed in quart baskets and shipped in strawberry crates. The fruit always sells better with foliage attached. This is an advantage, as the leaves help to fill up the baskets, and make a larger bulk than if the fruit alone were packed. The fruit is largely used for table decorations, and is in largest demand for Thanksgiving and Christmas holiday trade. Very appetizing jelly and marmalade may be made from the fruit, and it can also be crystallized. For commercial planting, or for use as an ornamental for home use only, Kumquats are weIl worth planting.

PRICES ON KUM QUATS-On Citrus trifoliata and Rough Lemon Stocks.

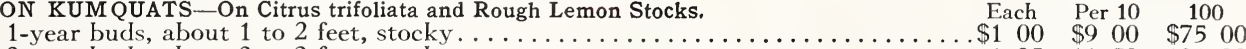

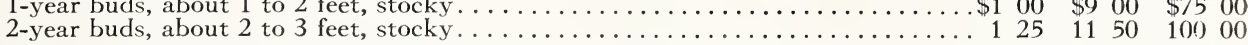

Marumi. Fruit round, about 1 inch in diameter; bright golden yellow. Rind sweet, with pleasant flavor; pulp and juice sprightly; very fine. Tree forms a well-rounded, symmetrical head.

Meiwa. Fruit round, slightly Iarger than Marumi; pulp sweet when fully ripe. Of recent introduction and very desirable. Best of all Kumquats to eat out of hand.

Nagami. Fruit oblong, about $1 \frac{1}{2}$ to 2 inches Iong and 1 inch in diameter; fruit golden yellow; rind sweet; pulp and juice sprightly, of fine flavor. Tree forms a nice head, more open than Marumi.

\section{LEMONS}

While not so hardy as the orange and pomelo, yet Lemons can be grown over a wide range of territory. Even in north Florida we have often been able to produce more fruit than we could use. Certainly no collection of citrus fruits for home use in the citrus belt is complete without a few Lemons, and in sections most immune from cold this fruit may be grown in quantity.

A number of years ago, before the newer sections of Florida were opened up, Lemons were raised in considerable quantities. A number of causes contributed to the reduction of the plantings, untiI at this time Lemons are grown in small numbers only. It is now quite certain that a return to the planting of this citrus fruit will make a profitable investment under proper conditions. The growing of Lemons for use in this state alone is an industry worthy of consideration. 


\section{$\overline{\text { SOUTHERN PLANTING FACTS }}$}

\section{Ponderosa Lemon}

An exceptionally Iarge Lemon, fruits weighing from $1 \frac{1}{2}$ to $2 \frac{1}{2}$ pounds. This fruit, while a great novelty, has at the same time a weII-defined usefulness. The juice from one of them will make a large pitcher of lemonade. It can also be used in all the culinary ways in which ordinary Lemons are used. It makes a very fine, thrifty, ornamental tree and bears heavy crops when quite young. Two or three of these trees should be included in every home orchard planting.

\section{Villa Franca Lemon}

In our test orchards we have grown and fruited for years aII the important commercial varieties of Lemons. As a result of these tests we are convinced that

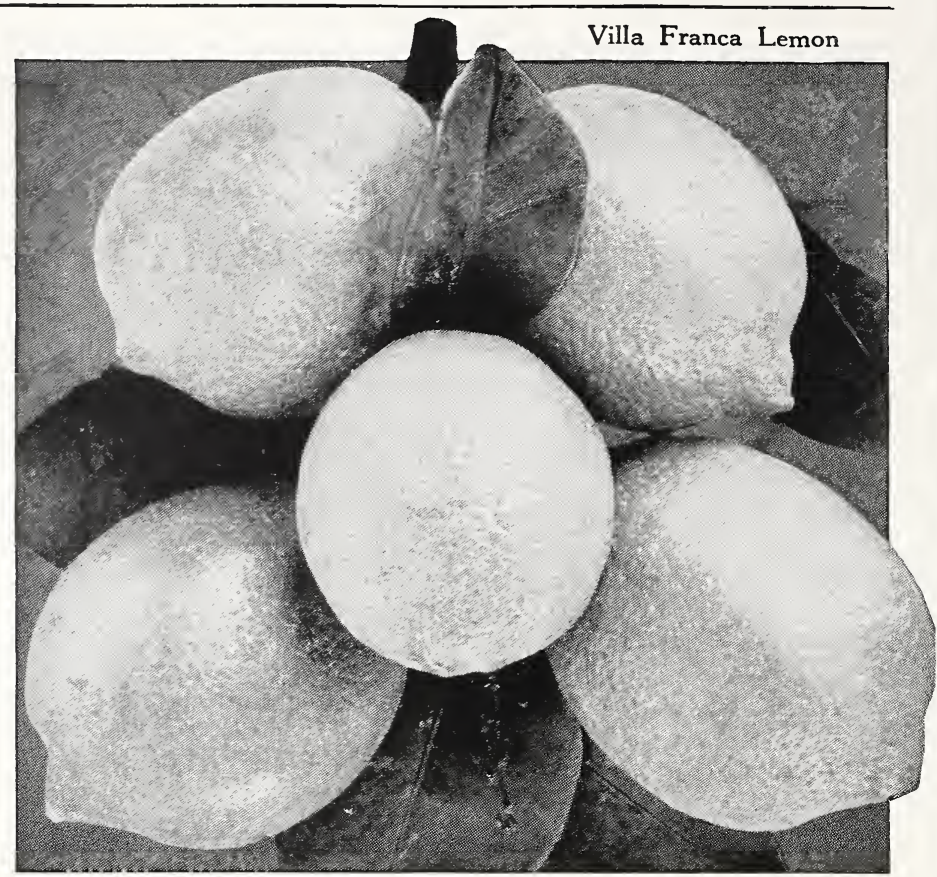

Villa Franca is the Lemon for Florida. It has taken first rank in many competitive exhibits, and is the variety to plant for either local use or for market. The fruit is juicy, strongly acid, and of fine quality, almost or quite seedless. The tree is quite free from thorns, a fine grower, and produces regularly fine crops of good fruit. A few trees to provide fruit for home use or for local market are a valuable addition to a citrus planting.

\section{The Tahiti Lime}

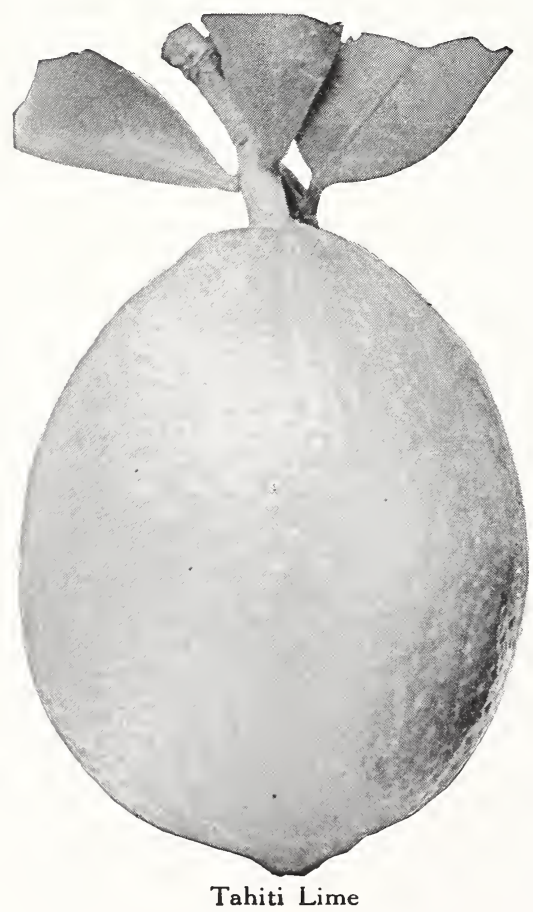

Of aII the acid fruits which may be grown in Florida, the Tahiti Lime is one of the most satisfactory for home use as weIl as for commercial planting. It is not quite so hardy as the Iemon and its culture should be confined to localities where there is little or no danger of injury from cold. It grows as a dense-foliaged, round-topped tree, 12 to 15 feet in height. It is a very vigorous grower and remarkably free from insect and fungous pests.

The fruit of Tahiti is of the finest quality for making ade. It is best suited for use when full size but while the skin is still green. In size and shape it resembles a small lemon, but it is a much smoother and nicer fruit. It is seedless, has a splendid Lime flavor, and is so much superior to other varieties of Limes that it is the only one we now propagate. Our experience has shown that the Tahiti Lime is a complete success on Rough Lemon stock. On this stock it makes a splendid growth and is very prolific. Matured fruit, partly grown fruit, and blossoms are found on the trees at nearly all seasons of the year, but the heaviest bearing season is in summer when the fruit is in greatest demand, and in a commercial way it is a valuable fruit for the local market where it meets with ready sale throughout the summer months.

There is no purpose for which Lemons or the smaller Limes may be used to which Tahiti is not equally adapted. The variety should be given a place in every home orchard in southern Florida.

Tahiti Lime 


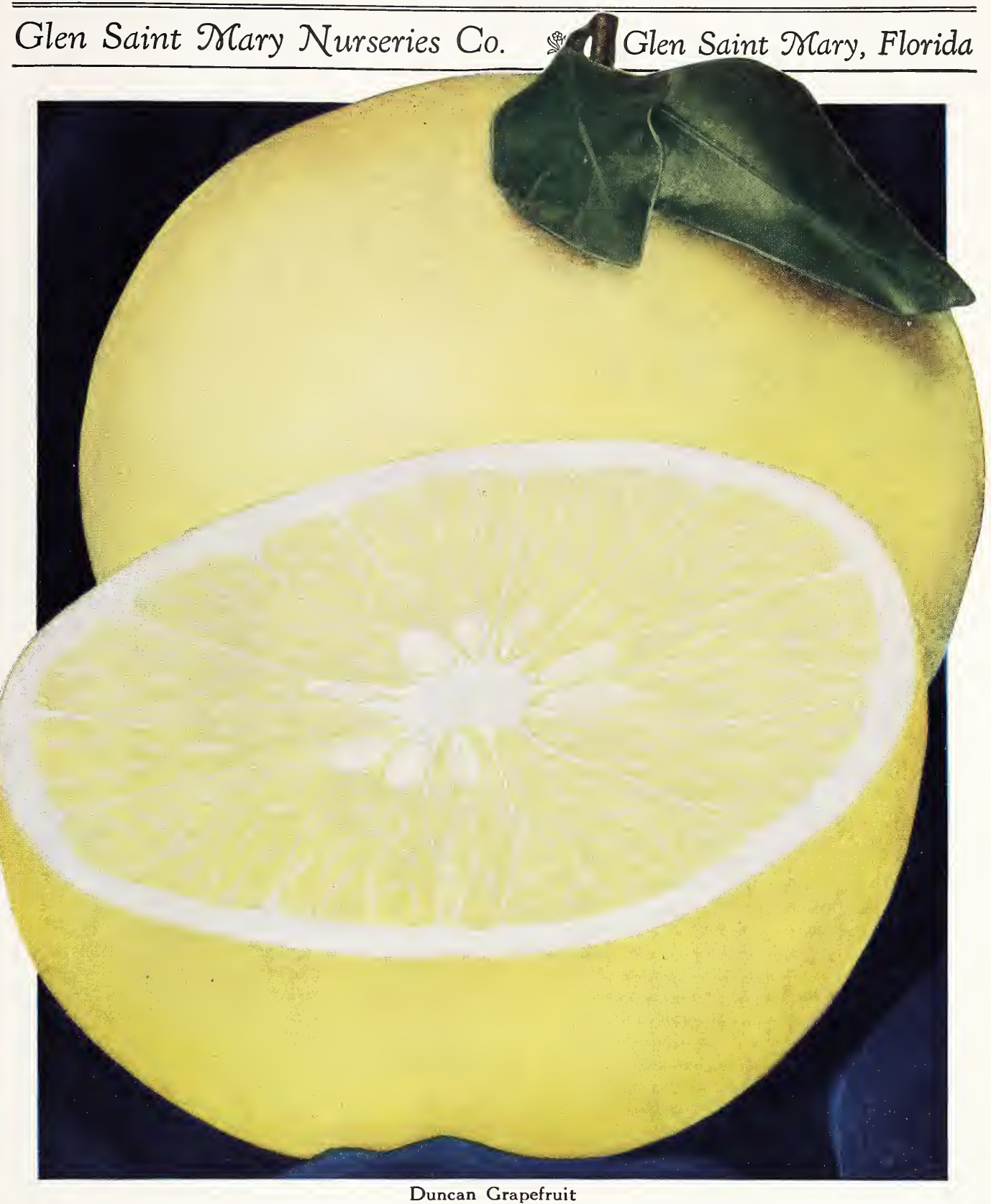

Duncan Grapefruit

\section{GRAPEFRUIT}

The Grapefruit industry of today is a growth of not more than forty years. The increase in cultivation, production, and use of Grapefruit is without a parallel in American horticulture. It is Florida's greatest single fruit contribution to the tables of the world, and it is in Florida that its culture has reached its greatest development. Its consumption has increased faster than the supply. Extensive advertising in various ways, resulting in wide distribution, has been a large factor in popularizing this comparatively new and very wholesome fruit. In addition, it should be remembered that, tree for tree a Grapefruit planting will produce twice the number of boxes of fruit that orange trees will at practically the same cost of production. For example, under the same conditions, assuming that a six-year-old orange tree will produce 2 or 3 boxes, a Grapefruit tree of the same age will yield 4 or 6 boxes. The market for Grapefruit is continually broadening, and canning the fruit has greatly widened its distribution. On the whole the Grapefruit outlook is very satisfactory. 


\section{SOUTHERN PLANTING FACTS}

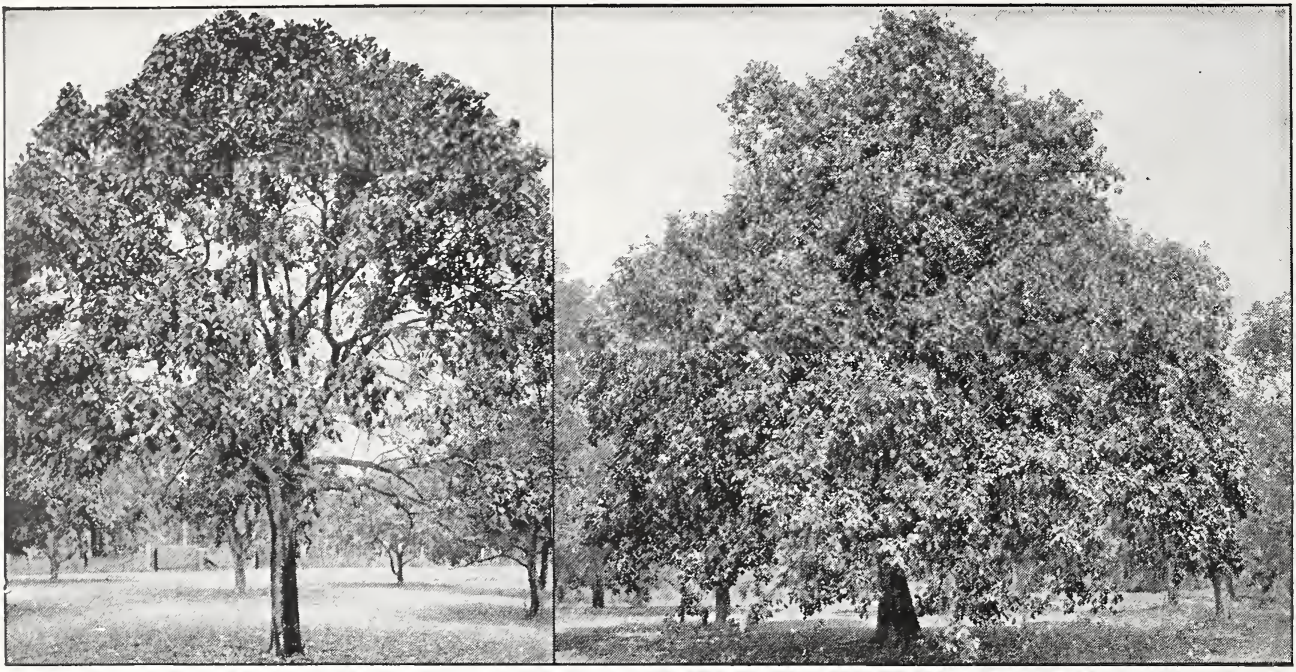

Original Duncan Tree

Sister Tree to Duncan

Though over eighty years old, these trees are still producing enormous crops of fruits

\section{Duncan Grapefruit}

We consider Duncan the finest Grapefruit grown. During all the years we have been in the citrus business (and during this time we have grown, observed, and tested a host of varieties), we have never found a Grapefruit which is quite the equal of Duncan in all-round desirability. It has everything a Grapefruit should have, and is lacking in no particular. Its size is exactly what the markets want and pay best prices for-54's to 70's. Its shape is round, slightly oblate, and it packs well. Color a clear light yellow, with oil-cells showing through the smooth skin. The juice content is particularly heavy and possesses more than any other Grapefruit the true sweet-bitter-acid-grapefruit flavor. The season of this fine Grapefruit is an extended one. It is ripe enough in color and quality to ship in early December, and it can be held on the tree without deterioration until late in May. We have been propagating Duncan for more than a quarter of a century. Our first budwood was secured from the originaI Duncan tree at Green Springs, Fla. It has weathered the storms, cold spells, and neglect of more than eighty years and is still bearing good crops. Through aII the cold periods which we have experienced during the past quarter of a century, both in north and south Florida, we have observed that Duncan invariably has suffered less than any other variety. It is unquestionably the hardiest of all the Grapefruit.

\section{Marsh Seedless}

This fine variety originated at Lakeland, Fla., and was first brought to notice and grown by $\mathrm{Mr}$. C. M. Marsh, about 1895 . Its most marked characteristic is its practically seedless fruit. Its marketing season begins in January, and, because it is so nearly seedless, the fruit can be held on the trees Iater than all other varieties except McCarty, which is equally late. The fruit is very handsome in appearance, with smooth yellow skin. The quality is fine, a great favorite in the markets, and always commands good prices. It is becoming known as a distinct variety, and seIls, not simply as Grapefruit, but under its own name. Like all other varieties of Grapefruit which we grow and recommend for commercial planting, Marsh Seedless fruits run in the sizes most desired by the fruit trade.

The tree makes a low, dense, spreading head, often measuring more across the spread of the branches than it does in height. It bears heavy, regular crops. In every weIl-balanced planting, Marsh Seedless should be given a liberal place.

\section{McCarty}

Many years ago the McCarty Grapefruit, an Indian River variety named after the Iate Mr. C. T. McCarty, attracted our attention. After keeping it under observation for several years, we decided to propagate it. It possesses in a marked degree the distinctive habit of producing its fruits singly instead of in bunches or clusters. This feature, coupled with its late ripening period and its very high quality have so impressed us with its merits that we have come to regard McCarty as one of the finest 


\section{Glen Saint Dary Nurseries Co. Glen Saint Dary, Florida}

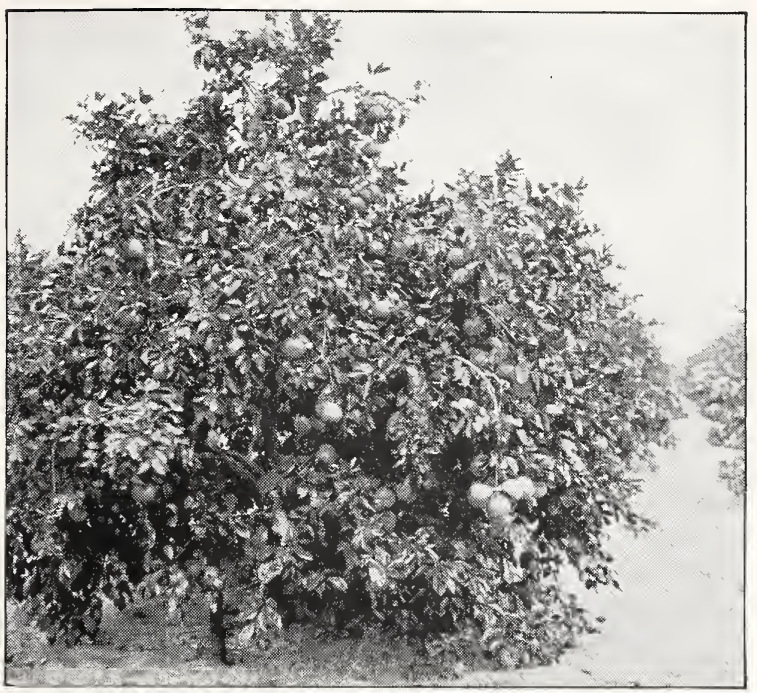

McCarty Grapetruit

\section{McCARTY GRAPEFRUIT, continued}

Grapefruits grown in Florida today. Because it does not grow in clusters, the fruit is very uniform in size and shape, and very free from those blemishes caused by clustering, such as extensive scale injury and misshapen fruits. We believe this variety is not surpassed by any other as a regular, uniform bearer. The fruit is of best market size, light, waxy yellow in color, with skin of beautiful texture. It is distinctly a fancy fruit; has a perfect Grapefruit flavor and the flesh is melting, free from fiber and rag when properly grown.

\section{Triumph Grapefruit}

There is always a demand for an early Grapefruit, particularly for home use or for Iocal market. Those varieties which ripen in midseason or Iater do not develop sufficient juice early in the season to make them satisfactory at that time. The Triumph Grapefruit fills the place of an early fruit better than any other variety with which we are acquainted. It is in good eating condition in November and has a season of about eight weeks depending upon the stock on which it is propagated and the citrus section where grown. It is a very prolific sort and the fruit, though smaller in size than our other varieties, runs very uniform. The size of the fruits may be materiaIly increased by judicious thinning late in June. It is heavy, juicy, weIIflavored, and smooth-skinned. It is sweeter than Grapefruit ordinarily is and in quality it is fine. The tree is quite an upright grower, with characteristic appearance and foliage. It is more susceptible to cold than other varieties and its location should be carefully selected.

\section{NEW AND UNCOMMON CITRUS FRUITS}

On this and the following page we are offering a few new or uncommon citrus fruits. After many years, the citrus fruits commonly grown in commercial plantings have become fairly well standardized. In reality, this is the outcome of a large experience gained by many growers in different parts of the citrus districts. Had it not been for the testing of many sorts, we would not today have the exact knowledge concerning the behavior of different varieties that we now possess.

The varieties described here are old enough to have been fairly well tested out, and they are, in our opinion, worthy of planting. Some of them will take a place in commercia plantings as soon as they become better known.

The home-orchard is a neglected side of citrus culture at this time. Citrus trees are almost invariably planted to supply fruit for some distant market, and the wonderful variety of very fine fruits for home use do not receive the attention they deserve. The varieties described here are weII worthy of a place in the home-orchard. From time to time, in the future, new sorts now under test will be added.

\section{Calamondin}

SmaII, $1 \frac{1}{4}$ inches in diameter, deep orange-red, flattened, with thin skin, easily separated from the puIp; sections easily separated as in the Mandarin oranges; juice clear, strong acid ( 5 per cent), with a pleasant, peculiar flavor. Very hardy, prolific, ripening during November and December. This citrus tree is very hardy. In north Florida it has

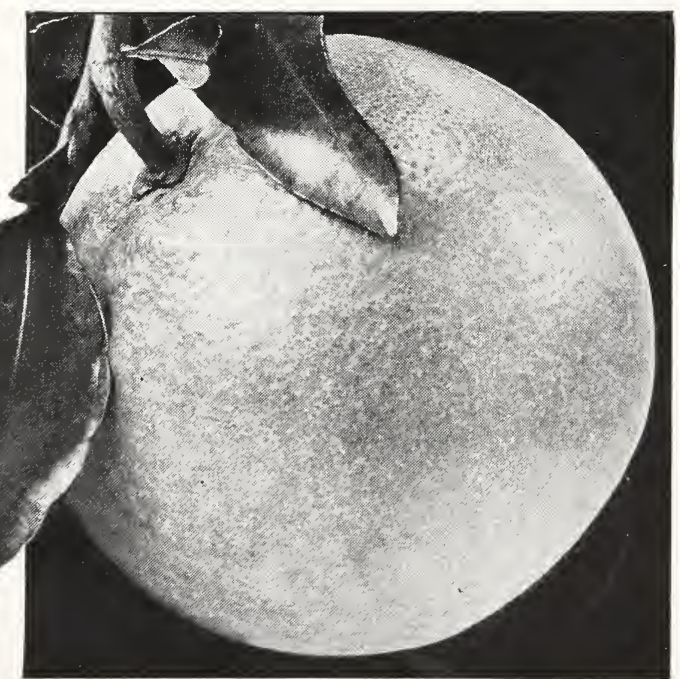

Foster Grapefruit. See page 64 


\section{SOUTHERN PLANTING FACTS}

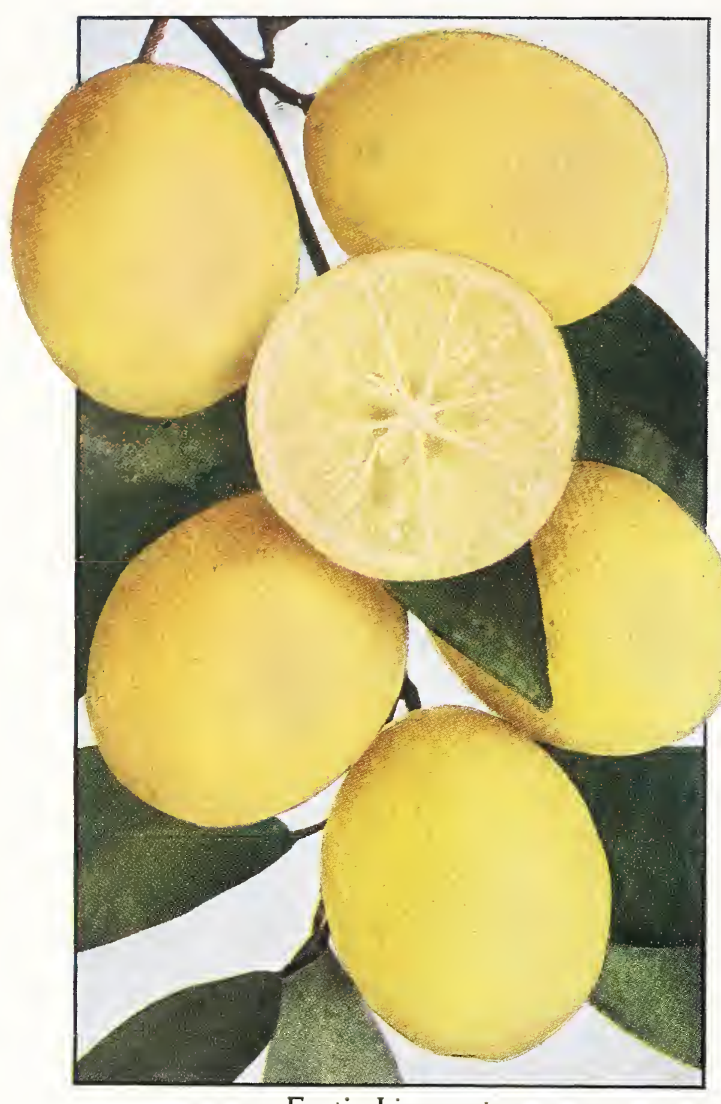

Eustis Limequat

\section{CALAMONDIN, continued}

shown itself to be nearly or quite as hardy as the Satsuma orange. It is a very handsome tree and well worth planting for its ornamental effect. The juice makes an "ade" that can hardly be surpassed.

\section{Eustis Limequat}

This new citrus fruit is the first of its kind offered to tree planters. It is the result of a cross made a number of years ago by Mr. Walter T. Swingle, of the U. S. Department of Agriculture, between the Nagami kumquat and a lime. Mr. Swingle was trying to secure a hardy acid fruit and has succeeded even beyond his greatest expectations.

The fruit is oblong or roundish oblong, somewhat larger than the ordinary run of Key or Mexican limes, with skin resembling that of the grapefruit in color and texture, but with a flavor or taste peculiar to itself. The acid is clear and strong and of finest quality. The tree resembles somewhat the Mexican lime in habit of growth. It is hardy and may be grown at least wherever the sweet orange can be produced, and the indications are that its culture may be extended beyond these limits.

The introduction of this fruit makes it possible to produce an acid fruit of finest quality throughout the entire sweet-orange area. It is a very important addition to our list of citrus fruits, whether for market or for home use.

\section{Foster Grapefruit}

The Pink Grapefruit

This variety of Grapefruit originated a number of years ago, as a bud sport on a tree of Walter's Grapefruit near Bradentown, Fla., and was introduced by Mr. E. N. Reasoner, Oneco, Fla., in We have had this variety in fruit in our test-grove for a number of years and are very favorably impressed with its quality and general excellence. The flesh is purplish pink in color and in quality it ranks as one of the best of the Grapefruits. The outstanding feature of this variety is the very excellent quality it develops early in the season, and we class it as one of the best, if not the very best, early Grapefruit that we know of. It is weIl worthy of extended trial.

\section{Mandarin Orange}

The Mandarin or China Mandarin Orange is an old sort. It has distinct value as an ornamental tree and in some sections, notably in southern Louisiana, it is given preference in commercial plantings. Years ago we used to grow this variety in considerable quantity; then dropped it from our lists. Recently we have had so many inquiries for it that we are again growing a few trees of it.

The fruit is of medium size, flattened, deep yellow, with thin skin and loosely adhering segments. The flesh is dark orange-yellow, spicy, and of good quality.

The foliage is fine and small, and the growth willowy, combining to make it a very beautiful tree.

\section{Thornton Tangelo}

As its name indicates, this citrus fruit is the result of a cross between the Tangerine orange and the Pomelo or grapefruit. It originated a number of years ago as the result of a cross made by Messrs. Swingle and Webber of the U. S. Department of Agriculture. In habit of growth it is similar to the grapefruit, but the skin is easily removed from the flesh; in this particular it is like the tangerine. The fruit is smaller in size than most grapefruit (which, in general, it resembles). The flavor is very agreeable, a new combination of flavors, as might be expected from its origin.

New and valuable citrus varieties on Rough Lemon stocks: Calamondin Lime, Eustis Limequat, Foster Grapefruit, Mandarin Orange, Thornton Tangelo; on Sour Orange stocks: Foster Grapefruit, Mandarin Orange, Thornton Tangelo. On Citrus trifoliata stocks: Calamondin Lime, Eustis Limequat, Mandarin Orange.

Prices, $\$ 1.25$ each, $\$ 11.50$ for $10, \$ 100$ per 100 


\section{Glen Saint Dary Nurseries Co. Glen Saint Mary, Florida}

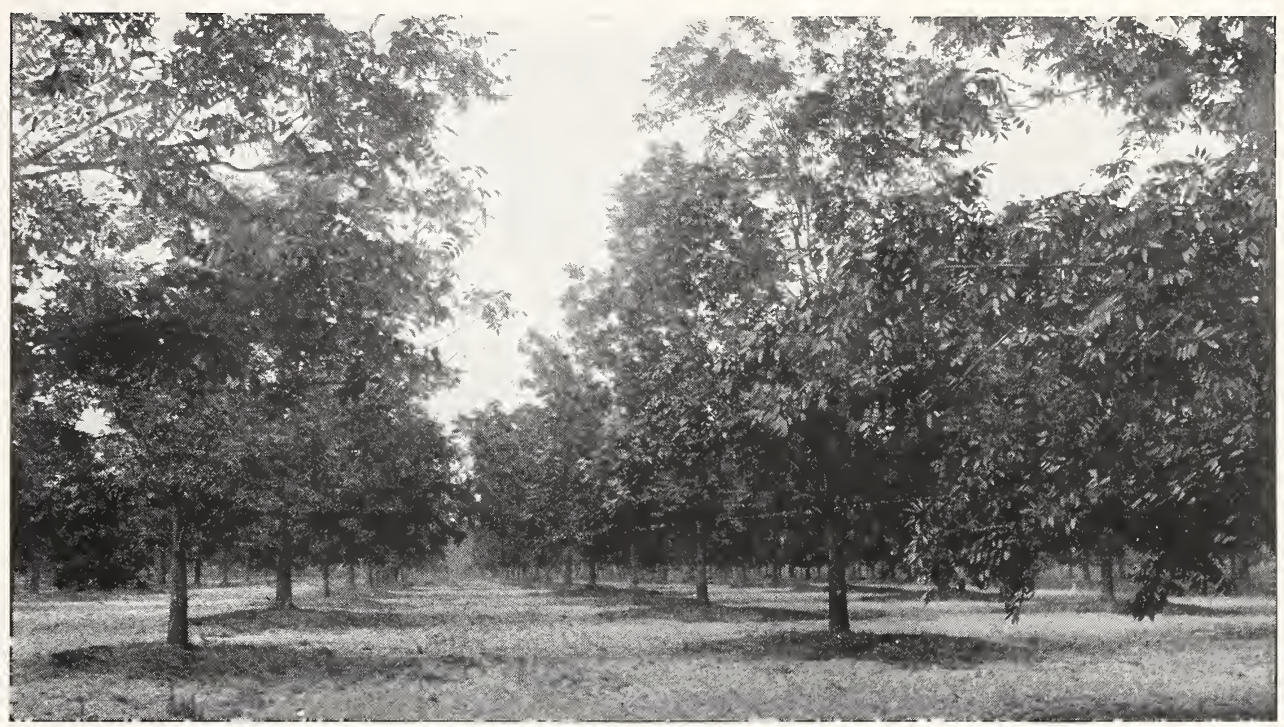

\section{PECANS}

In recent years the Pecan has become a very important nut, particularly in the Southern States, and it may be said that there is no other fruit or nut tree which fits so well into the general farming of this region as the Pecan. Cotton, corn, cowpeas and other farm crops can be grown to advantage among the trees when they are young, and even until the trees have begun to bear well. In short, the land may be farmed almost as though the trees had not been planted on it, yet the trees, under this management, will grow and do well. The region in which the Pecan may be grown, with a proper selection of varieties, extends from Virginia to Florida, thence west into Texas and Oklahoma. It is destined to become the most important horticultural tree in this whole region, and the Pecan orchards of the South will rival the apple orchards of the North and Northwest. The Pecan, under proper conditions, will continue to bear fruit long after other fruit trees planted at the same time have ceased to grow; in fact, a Pecan orchard is equal to many peach orchards - for instance, in length of life and fruitfulness. They make handsome specimens for street, road, and yard planting.

PECAN SOILS. While it is a fact that the Pecan tree will succeed on a wide range of soils, it is wise, since it is a valuable, long-lived tree, to choose good land for the Pecan planting. This soil should not be low and wet; it should be well drained, yet it should contain a goodly supply of moisture. Sandy Ioams underlaid with clay, light clay lands and alluvial lands are suitable. The land should contain humus in large amounts for best results. Before planting, the land should be thoroughly cleared of stumps and roots; if it is good farm land, and in good farming condition, it will be ready for planting at once, but new lands, or those deficient in humus or vegetable matter, should be well broken, and planted in cowpeas or velvet beans for at least one season before planting. In autumn, after the vines are dead and dry, they should be plowed back into the land, and the soil weIl harrowed to put it in best condition.

CULTIVATION. The best cultivation for a Pecan tree does not differ materially from that given other kinds of fruit trees. The orchard should be plowed in autumn. Cultivation should begin early in spring before growth starts and should continue at intervals of a week or ten days until about the first of July, when cultivation may be discontinued. If the land is planted in truck or farm-crops, there should be a strip of 5 to 6 feet on each side of the tree rows left unplanted. This strip should be cultivated regularly, to conserve moisture and keep the trees in good growing condition. In six to eight years after planting, the trees will begin to bear light crops, and by ten years they should be vielding fairly well. After this, it is doubtful whether it is good practice to continue cropping the land, both because the trees need the land and because the shade cast by them will interfere with the crops. Indeed, cropping may have to cease earlier, particularly if the trees are closely planted. Crops of cowpeas, beggar-weed or other legumes should be grown from time to time and turned into the land. A good fertilizer for young trees is one containing about 4 per cent ammonia, 7 per cent plosphoric acid and 3 per cent potash. For bearing trees increase the potash to about 5 per cent.

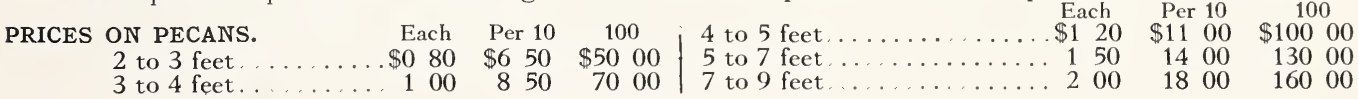




\section{SOUTHERN PLANTING FACTS}

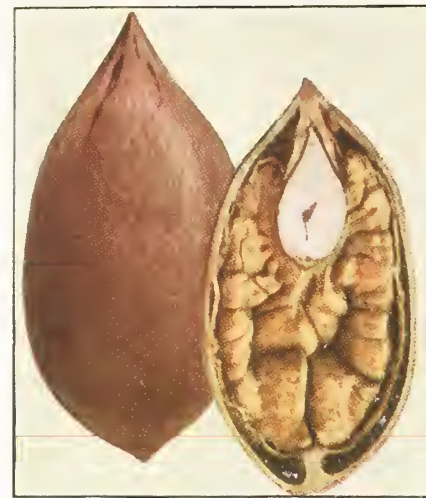

Curtis

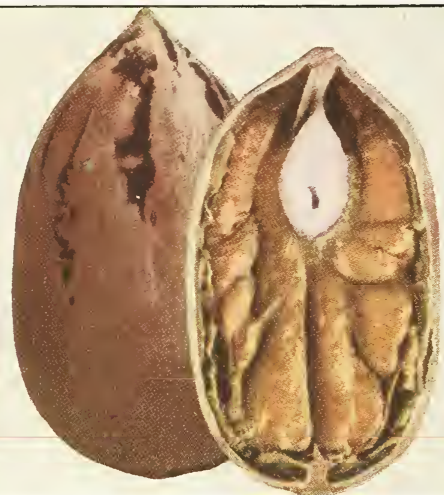

Frotscher

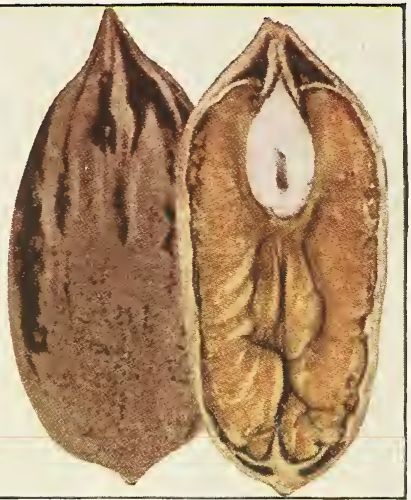

Schley

\section{Varieties of Pecans Described}

Curtis. A medium-sized Pecan, with bright, clean shell, marked with a few purplish specks; ovate, rounded at base, pointed at the apex; sheII very thin; cracking quality excellent; kernel yellow; plump, fuIl; rich, nutty flavor.

Frotscher. A Iarge, oblong nut, $13 / 4$ to $17 / 8$ inches in length; bright yellowish brown in color with a few purplish black markings; shell very thin, cracking easily. Kernel Iarge, easily removed, full, of good quality. Tree vigorous, of spreading habit with scaly bark; bears heavy crops and can always be depended upon.

Moneymaker. Size medium, 11/4 by 1 inch, rounded, oblong; light yellowish brown shell of medium thickness, cracking easily; kernel full, plump, rich. A heavy bearer of splendid nuts and adapted for planting over a wide territory.

Schley. Size medium to Iarge, $1 \frac{1}{2}$ to $17 / 8$ inches long; oblong, somewhat flattened; light reddish brown; sheIl thin, separating easily from the kernel; kernel full, plump, bright in color; flavor rich, nutty; quality best.

Stuart. Nuts large to very large, $1 \frac{1}{4}$ to 2 inches long; oblong; brownish shell; strongly marked with dark color. Shell of medium thickness and of very good cracking quality. Kernel full, plump, bright-colored. Heavy bearer. Gives satisfaction in many parts of the country and is being widely planted.

Success. Size large, oblong, tapering to the apex. Color reddish brown, shell thin, cracking quality good, partitions thin; kernel large, fuII, plump, yellow; flavor sweet; quality very good. A good grower and a heavy and regular bearer.

\section{The Pecan and Its Culture. By H. HAROLD HUME}

Pecans are rapidly becoming one of the most important orchard trees in the South. In fact, for general planting they are entitled to first place because of their peculiar adaptability to many conditions and locations. The merits of this valuable nut are being recognized as never before, and the crop has gained a firm place in the markets of the country. To supply reliable information on Pecan-growing, this up-to-date work, touching every cultural detail, has been prepared after many years' careful study of the industry. The book is thoroughly practical and contains the information needed by every grower of Pecans. Third edition, 195 pages, cloth-bound; price $\$ 2$, postpaid.

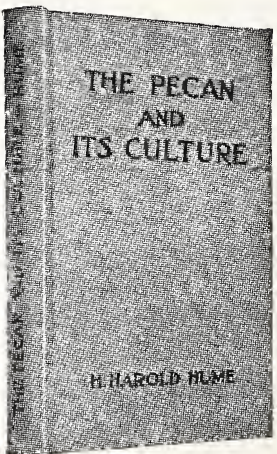

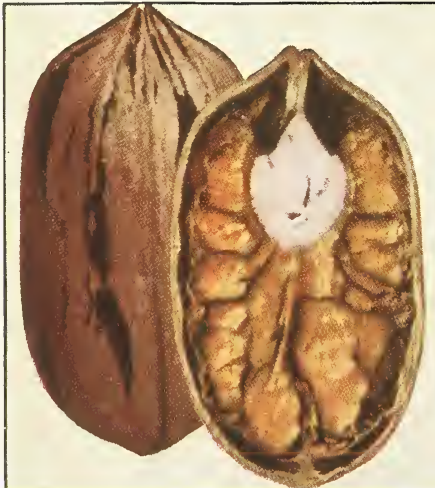

Stuart

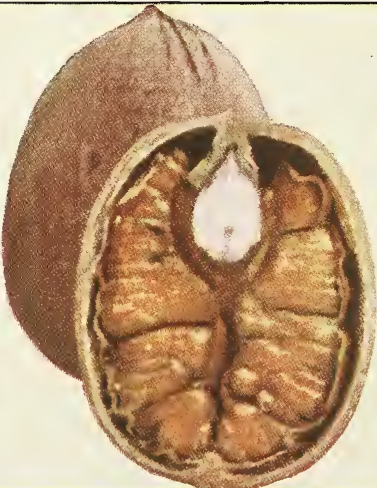

Moneymaker

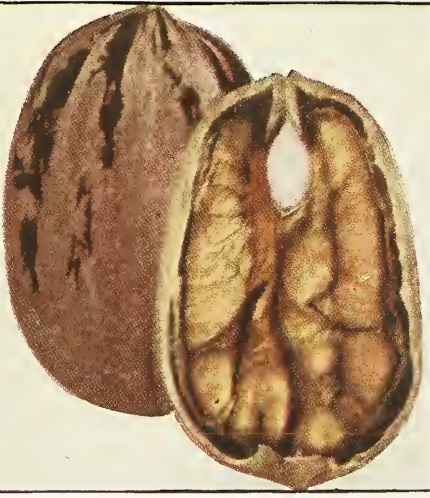

Success 


\section{$\overline{\text { Glen Saint Jary Nurseries Co. Glen Saint Jary, Florida }}$}

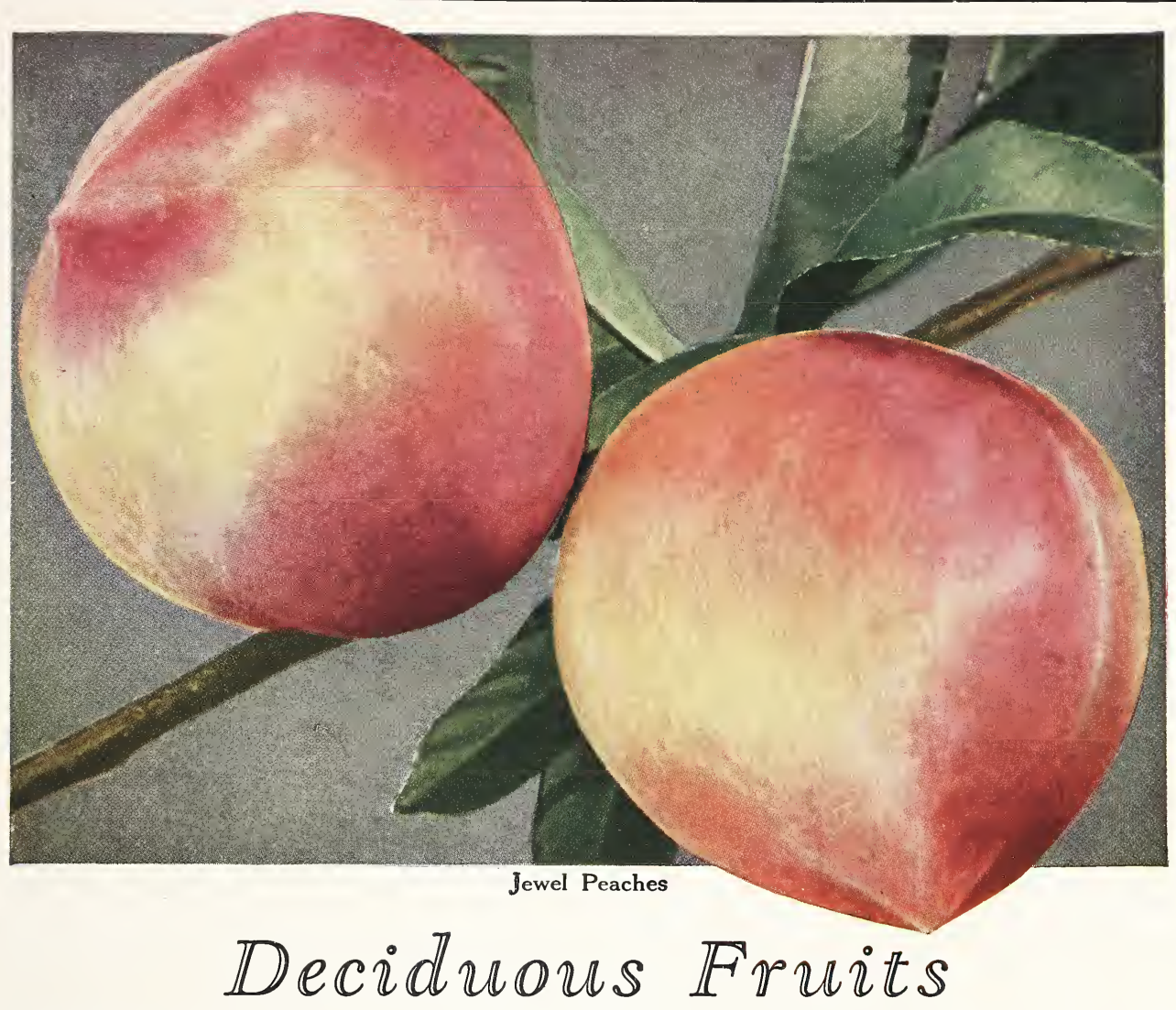

TN THE Lower South there are a number of deciduous fruits of decided merit which may be planted to advantage, either in commercial orchards or for home use. The most important are Peaches, Plums, 1 Persimmons, Figs, Pears, and Grapes. To a less degree, Pomegranates and Mulberries are weIl worth while. It may seem strange to include the Pear, for instance, but the Pear, since the introduction of blight-resistant varieties, is coming back again. We have a large number of these under test.

\section{PEACHES}

For forty years we have been studying Peaches. During this period we have originated and introduced a large number of different kinds. We have throughout this period been growing nursery trees. Our land is particularly adapted to the growing of fine Peach stock, and we are able to offer our customers the best trees that can be produced. They are "Quality trees" of the very best strains.

Varieties should be carefully selected, to have them adapted to the section where they are to be planted. This done, good trees planted on new land with good drainage, and carefully cultivated, will bring quick returns, and are among the most satisfactory fruits that can be grown.

The types of Peaches are as follows: Persian, commonly planted in the North. Northern Chinese, which includes Elberta and related varieties, generally planted in the cotion-belt; well adapted to western Florida. Spanish, native varieties that have originated in Florida and on the Gulf Coast, adapted to the Iatitude of northern Florida. Honey, comprising the Honey and its seedlings, adapted to northern Florida, southern Georgia and westward around the Gulf. Peen-to, comprising the originaI Peen-to and the varieties originated from it; weIl adapted to Florida, tropical and subtropical regions PRICES ON PEACHES.- On Native Peach Stock.

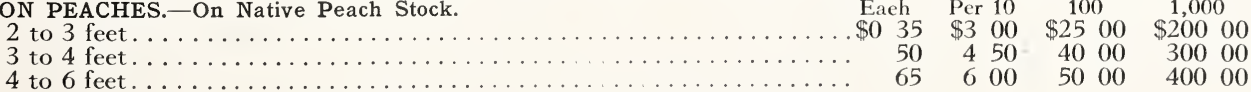

\section{PEACHES ON PLUM STOCK}

Owing to a persistent demand for Peaches on plum stock from some sections, we have propagated a limited number of Angel, Dorothy N., Florida Gem, Gibbons' October, Jewel, Luttichau, Peen-to, Suber, and WaIdo Peaches on plum roots which we offer at the same prices as for Peaches on Peach roots. 


\section{SOUTHERN PLANTING FACTS}

\section{List to Aid Selection}

In assigning varieties to districts of wide area, there will be local exceptions, but the following lists are based on many years of extensive planting, experimenting, research and observation.

SUCCESSION OF RIPENING. The terms "very early," "early," “midseason," and "late," in the following list (as indicated to the right of each variety by the abbreviations "VE," "E," "M," "L") indicate the general comparative ripening time of the variety.

EXPLANATION OF LIST. The varieties best adapted and most valuable in a particular zone are indicated by two asterisks $(* *)$; varieties next in order of merit by one asterisk $\left(^{*}\right)$.

Zone I. South Florida, West Indies and other islands, Subtropical and Tropical Sections.

ZoNe II. Eastern North Florida.

Zone III. West Florida and Lower Georgia, Alabama and Mississippi.

Zone IV. Coastwise Louisiana and Texas.

Zone V. Other Sections of the United States.

\section{ZONE ADAPTATION LIST}

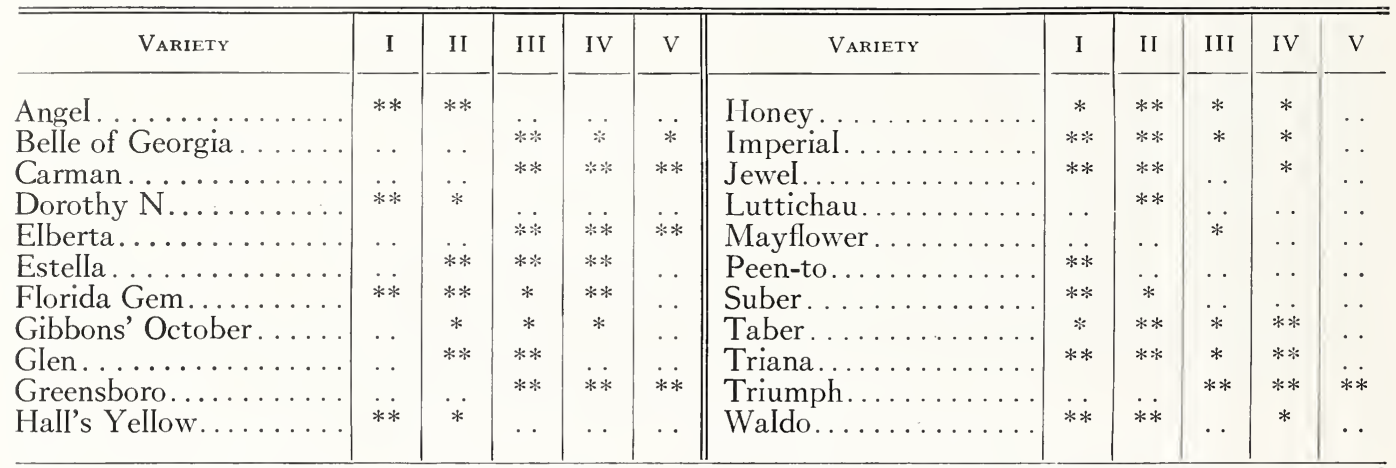

\section{Varieties of Peaches Described}

The abbreviations in parentheses below, following the names of varieties, indicate the race to which they belong. Thus (Sp.) means that the variety belongs to the Spanish race; (Per.) to the Persian race; (N. C.) Northern Chinese; (Hon.) Honey; (P.-to.) Peen-to. The dates given for the usual time of ripening are based on northern Florida.

Angel. (P.-to.) Large, rounded, slightly pointed; color yellow, washed with red, very handsome; flesh white, sweet, melting, juicy, subacid, of exquisite flavor, entirely lacking in bitter-almond flavor; freestone. The tree bears while young, and is very prolific. It blooms a month later than Peen-to, thus escaping injury from frost in many sections. A very satisfactory variety. June 20 to 30 .

Belle of Georgia. (N. C.) Very Iarge; skin white, with red cheek; flesh white, firm and of excellent flavor; fruit uniformly large and showy; free. Rapid grower; prolific. July 1 to 15.

Carman. (N. C.) Of Iarge size, resembling Elberta in shape; skin creamy white or pale yellow, with deep blush; flesh tender and of fine flavor; juicy; freestone. Prolific bearer and profitable market variety. June 10 to 20 .

Dorothy N. (P.-to.) A seedling of Angel, and a very handsome Peach, of large size and fine quality. Shape nearly round, flesh yellow; rich subacid, of excellent flavor. It bears weIl, and is valuable for southern Florida. In its season, July 5 to 15 , one of the best for market or home use.
Elberta. (N. C.) Very large; yellow, with red cheek; flesh juicy, yellow and high-flavored; free. One of the finest and most valuable varieties, and perhaps more Iargely planted than any other one variety in America. Succeeds in west Florida and throughout the territory northward, but not in south Florida. July 5 to 20.

Estella. (Sp.) Almost round, very large; skin yellow or greenish yellow, with full red cheek; flesh yellow; freestone. Tree vigorous and very productive. Originated in west Florida. Ripens September 1 to 10 , just when there is but little southern fruit in market. One of the best late sorts for home use and local market.

Florida Gem. (Hon.) A Honey seedling of large size; roundish oblong, pointed; highly colored; flesh sweet, rich, juicy, red at the stone; very fine; free. One of the most valuable market varieties of Honey strain. July 1 to 10 .

Gibbons' October. (Sp.) A medium to large freestone, of the Spanish group, in quality unexcelled by any extremely late Peach that ripens this far south. Tree vigorous and handsome. Sept. 25 to Oct. 15. 


\section{Glen Saint Mary Nurseries Co. Glen Saint Mary, Florida}

\section{PEACHES, continued}

Glen. (P.-to and H.) A Iarge, oval, pointed Peach, a Peen-to-Honey cross; blunt-pointed, with deep suture; yellow, dotted and washed with red, practically red all over; skin thin, tough; flesh free, light yellowish, red about the pit; shipping quality excellent. Season June 1 to 15 . A very desirable sort, and a most profitable one for market.

Greensboro. (Per.) Originated in North Carolina and is being extensively planted in the central South. Of good size, nearly round; skin highly colored, bright red over yellow; flesh white, very juicy and of fine quality. Semi-cling. Valuable market variety. About June 1.

Hall's Yellow. (P.-to.) Large size, nearly round; yellow washed with red; flesh yellow, red at stone, from which it parts freely. Quality good. Ripens middle to latter part of June.

Honey. (Hon.) Medium size, oval, compressed, with deep suture on one side, extending more than half way round, and terminating in a sharp, peculiar, recurved point; skin whitish yellow, washed and marbled with red in the sun; flesh creamy white, fine, juicy, melting with peculiar honeyed rich, sweet flavor; quality excellent; free. June 5 to 20.

Imperial. (Hon.) Very large, roundish, oblong; skin greenish yellow, washed with red; flesh white, sweet, juicy, of excellent flavor and good tone; quality best; free. Originated by ourselves. June 25 to July 5.

Jewel. (P.-to.) Medium to Iarge; rounded to oblong; highly colored, red on exposed parts; flesh yellow, red about the pit, juicy, melting, sweet; excellent quality; freestone. Ripens about two weeks earlier than Waldo. A good shipper; tree very vigorous and healthy. This is the most valuable market variety for southern Florida and all tropical and subtropical regions. It stands without an equal as the commercial market variety for these sections. We introduced this variety years ago and have made it one of our special lines of stock ever since.

Luttichau. Size large; oval, with medium deep suture, rounded or blunt pointed at apex; color waxy greenish white washed or blushed with red, dotted on shaded specimens; skin thin, tough; flesh white, red at pit, solid, juicy, flavor sweet, quality excellent; pit medium-sized, free; a splendid shipper. Season May 25 to June 10. This fine Peach originated on the place of Baron H. von Luttichau, Earleton, Fla., a number of years ago. Mr. von Luttichau propagated from it and planted an orchard of his own which proved very profitable, the fruit bringing the top price wherever marketed. Originated in the same region as Jewel, Waldo and Angel. We have known this variety for years and regard it as one of the finest commercial Peaches for Florida.

Mayflower. (Per.) Large; well-colored; red all over; of fine quality; cling. A very promising variety. Its earliness, high color and excellent quality are strong points in its favor. One of the earliest of its group.

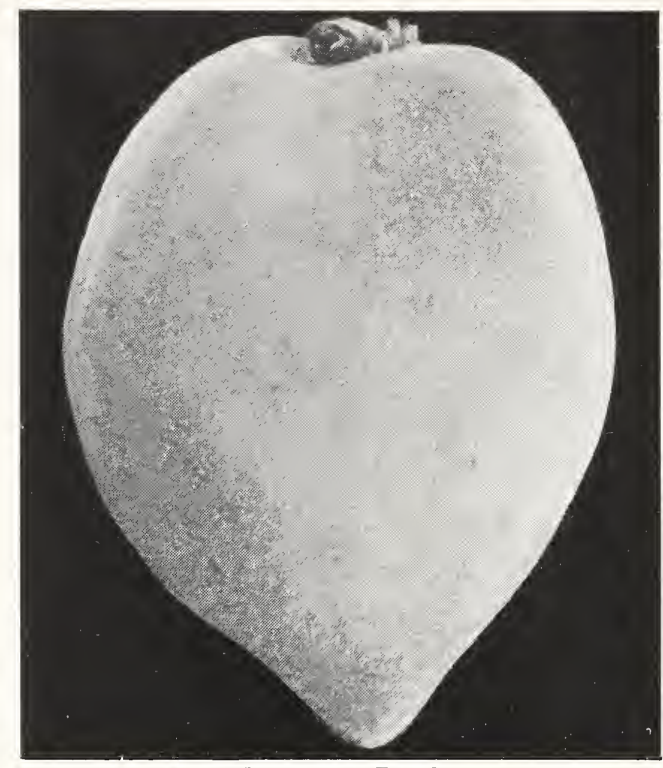

Luttichau Peach

Peen-to. (P.-to.) A curiously formed Peach, flattened at both ends; color greenish white, washed with red on exposed parts; flesh light yellow, sweet, rich, juicy, of good flavor, with a slight bitter-almond flavor; cling, pit smaIl, flat. Peen-to and its seedlings are among the most tropical Peaches. Ripens in northern Florida May 20 to June 3.

Suber. (P.-to.) This seedling of the Peen-to Peach originated at Lake Helen in southern Volusia County. The fruit is a clingstone, Iarge, firm, quite acid and brings a high price in market. The tree is a vigorous grower and very prolific.

Taber. (Hon.) Large, roundish, oblong, pointed; skin white, overspread with red; flesh white, streaked with red, firm, very rich, juicy subacid, of fine quality; cling. Honey seedling, prolific. Fine for canning. June 15 to 25.

Triana. (Hon.) Medium to Iarge, roundish oblong, slightly pointed; skin white, overspread with red; flesh white, with red markings, rich, juicy, very sweet and of fine flavor; freestone. This variety, originated by us several years ago, is one of the very best. June 25 to July 5 .

Triumph. (Per.) Fruit of large size, with very smaIl pit; skin yellow, nearly covered with red, dark crimson in the sun. Flesh bright yellow, free when fully ripe, of excellent flavor. About June 1.

Waldo. (P.-to.) Size medium, round, oblong; highly colored, light yellow, dark red on exposed parts; flesh yellowish white, red at the stone, juicy, melting, sweet, of excellent quality; freestone; prolific. Ripens with Peen-to, somewhat Iater than Jewel. Valuable for Florida and the Gulf Coast country. 


\section{SOUTHERN PLANTING FACTS}

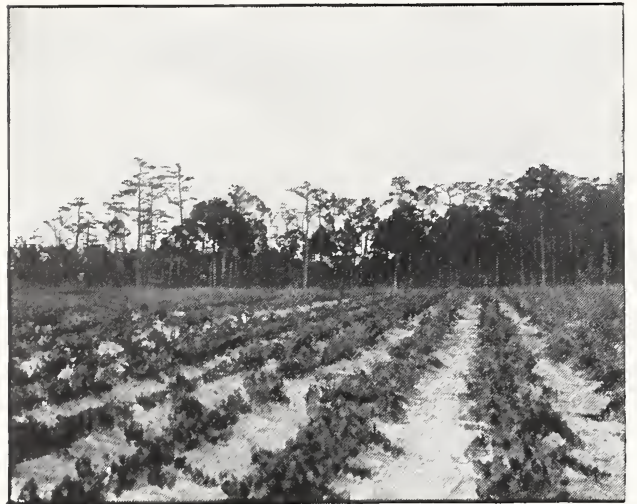

View in Grape Nursery

\section{GRAPES}

Grapes of the Muscadine group are native to the South, and are weIl adapted to the soil and climate. When compared with the Bunch Grapes, the fruitclusters are smaII, but the fruit is fine-flavored and valuable as a table Grape, for making unfermented grape-juice, preserves, jellies and wines. In Virginia and North Carolina they are extensively grown for making grape-juice.

Muscadine vines are long-lived, reaching a healthy, vigorous old age. They should be planted 15 to 25 feet apart each way. The usual plan is to allow them to run on an overhead trellis, $6 \frac{1}{2}$ to 7 feet from the ground. The posts should be heartpine, cypress or cedar.

In the Lower South, the northern Bunch Grapes, while not so thoroughly at home, can be grown to perfection for home use and for local market, when well cultivated, sprayed and cared for. The leading varieties are Delaware, Diamond, Ives, Moore's Early and Niagara. Every planting should contain at least a few of these varieties for home use and many of them are valuable for local market.

The best trellis for the Bunch Grapes in the Lower South is the Munson three-wire trellis. The vines should be planted 8 to 10 feet apart. It is an excellent plan to bag the bunches of fruit, using for this purpose two or three-pound ordinary paper sacks.

PRICES ON GRAPES.-Muscadine and Bunch.

1 -year
2-year
3-year

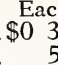

$\begin{array}{rrr}\text { Each } & \text { Per } 10 \\ \$ 035 & \$ 3 & 00 \\ 50 & 4 & 50 \\ 65 & 6 & 00\end{array}$

100

$\$ 2500$

$\$ 2500$
400

5000

1,000 $\$ 20000$ 30000 40000

\section{Muscadine Grapes}

Flowers. Bunches composed of fifteen to twenty large, purplish black berries; sweet, vinous, good quality. August and September.

James. Very valuable. The largest of the Muscadine group, berries often measuring $3 / 4$ to $11 / 4$ inches in diameter; prolific; black, juicy, sweet. Has taken premiums wherever exhibited. Ripens from August until late in the fall.

Scuppernong. Muscadine type. Bunches composed of eight to ten very large berries, bronzecolored when fully ripe; flesh pulpy, sweet, with

\section{Bunch Grapes}

Armalaga. A healthy, vigorous-growing variety producing large clusters of yellowish green Grapes. This is an excellent shipper of high quality.

Beacon. An early-ripening variety. The bunches are large, the fruit black and of excellent quality. A strong-growing, healthy Grape.

Carman. Berries Iarge, black, borne in large clusters. Skin, tough, thin; pulp meaty; quality excellent. Very popular in the Lower South.

Concord. Bunches and berries very Iarge, blue-black, with bloom; flesh sweet, pulpy, tender, good. A vigorous grower and heavy bearer. Very desirable for home markets. July.

Delaware. Bunches small to medium; berries small, skin red or pink, and very thin; sweet, juicy, vinous; quality best. Very popular and considered the finest American Grape.

Diamond. A handsome white grape equal or superior to Niagara in quality, and ten days earlier. Prolific, very thrifty and vigorous, and one of the best for the South. peculiar, agreeable, musky flavor; quality excellent. One of the oldest and best varieties of the Muscadine Grapes in cultivation. Ripens in August and September.

Thomas. Belongs to the Muscadine type, and one of the best of its class. Color reddish purple; pulp sweet, tender. Very Iargely planted. August and September.

Male Muscadine. Muscadine Grapes bear much larger crops if a pollen-bearing vine is planted near to furnish pollen.

EIlen Scott. The berries are pinkish violet in color, borne in large clusters. It is a desirable variety for local market and home use. Vigorous and healthy.

Ives. Strong grower; very productive; stands shipping weII; bunches large; berries large, black, pulpy, sweet, of good quality. A favorite for supplying $d$ is $t$ a $n t$ markets. June.

Niagara. B u $\mathrm{n} \mathrm{h}$ and berry large; greenish yellow; flesh sweet; quality good. A strong growing prolific variety well adapted to the South.

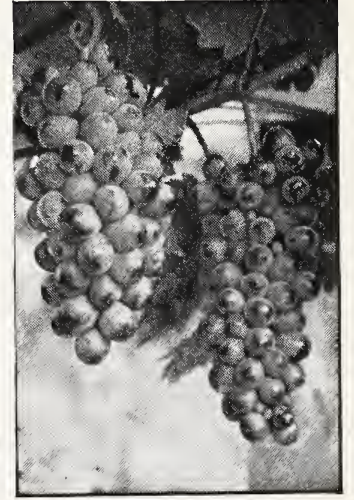

Niagara Grapes 


\section{PLUMS}

In the extreme South, particularly in central and south Florida, southern Texas, and, in fact, aII along the Gulf Coast, the pure-bred Japanese varieties have not been good bearers, consequently were not generally profitable. But cross-bred varieties-Japanese varieties crossed with native varietieshave proved heavy annual bearers. These cross-bred varieties have made commercial Plum-growing not only possible, but worthy the attention of fruit-growers even in south Florida and northern Mexico. Of these cross-bred Plums we can heartily recommend Excelsior, McRea and TerreII. These are excellent kinds, heavy bearers, and have given our customers satisfaction over a very wide range of territory.

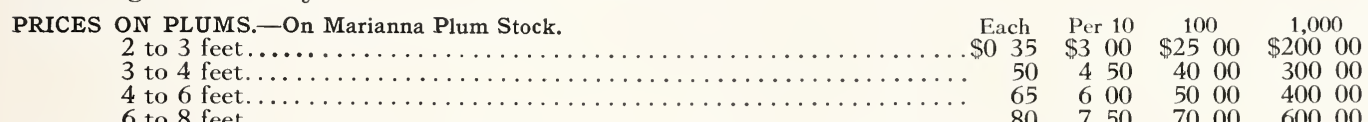

Abundance. Medium to Iarge; round with blunt-pointed apex; pinkish red changing to purplish red with thick bloom and numerous medium-sized dots; flesh greenish yellow, juicy, sweet or slightly subacid; pit small; cling; quality best; prolific; strong grower. A popular and profitable early Plum for planting in northern sections and in many parts of the South.

Burbank. Size Iarge to very large; rounded and blunt-pointed; dark red, mottled over yellow ground; thick bloom and numerous large dots; flesh deep yellow, juicy, sweet, firm; pit smaII; cling; quality one of the best. Tree very vigorous, upright branches with large leaves. Very popular both North and South; but not adapted to the Lower South.

Chabot. Fruit large, about 2 inches in diameter, oblong-conical; color pink-red, with numerous small dots; flesh yellow, solid, tart; cling; quality very good. Tree vigorous in growth.
Kelsey. Size very large; heart-shaped, longpointed, usually lop-sided with deep suture; color greenish yellow sometimes flushed with red covered with thick, bluish bloom; very showy; flesh light yellow, meaty; flavor rich, pleasant, quality excellent; prolific and bears while young. Highly recommended for the colder sections, but not dependable far south.

McRea. (Hybrid.) Fruit of medium size, flattened, rounded, oblique at apex; yellow undercolor washed with duIl red, dotted with smaII, light dots and covered with delicate bluish bloom; flesh yeIlow, juicy, subacid, firm; flavor aromatic, pleasant; quality excellent; prolific, good grower. We believe this worthy of extensive planting.

Persian Purple-leaved (Prunus Pissardii). Fruit medium, round; fruit and flesh crimson; quality good, cherry-flavored. Tree a good grower valuable as an ornamental, as it retains its vivid purple foliage until late in the season.

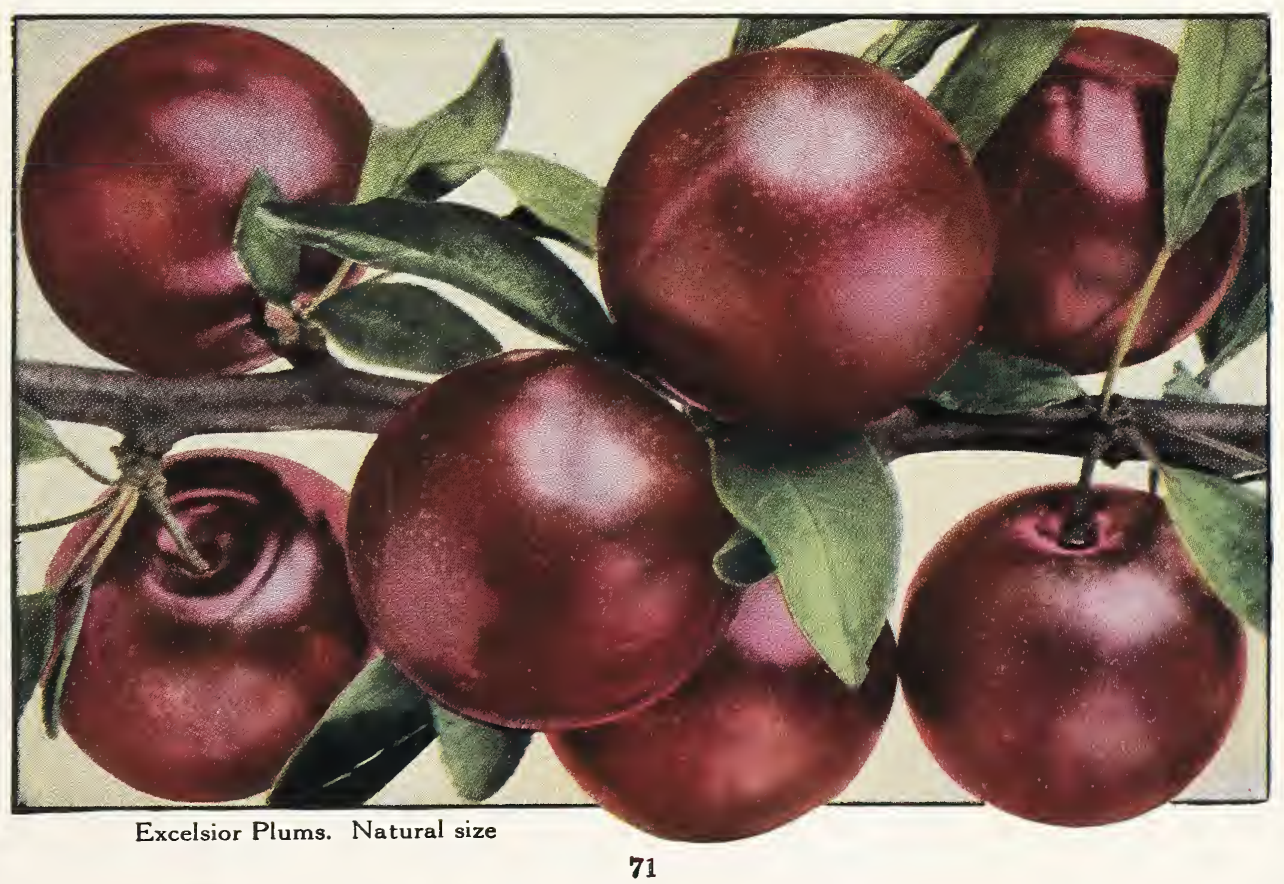




\section{$\overline{\text { SOUTHERN PLANTING FACTS }}$}

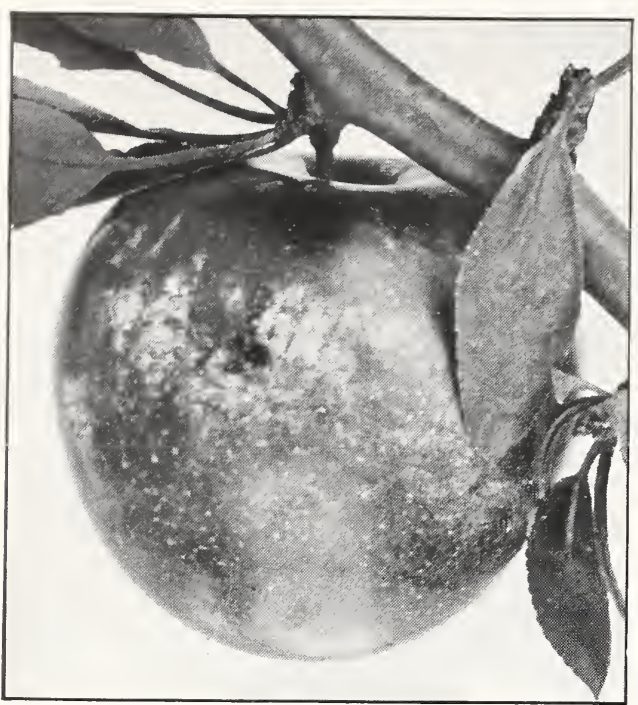

Terrell Plum

Red June. Fruit medium to Iarge, cordate, elongated at the apex, lop-sided; suture deep; color vermilion-red aIl over with delicate bloom; very showy; flesh light, yellow, firm, moderately juicy, sweet or slightly subacid; pit small; cling; flavor pleasant; quality very good. Tree vigorous and prolific. A good variety.

Satsuma. Medium to Iarge, broadly conical, with blunt, short point and deep suture; color dark, duIl red aII over with greenish dots; flesh purplish red; pit smaII; free; frrm, juicy; quality excellent; a splendid keeper and good shipper.

Terrell. (Hybrid.) A strong, healthy grower; very similar in habit to Excelsior; fruit large, $1 \frac{1}{2}$ to 2 inches in diameter, nearly round, bluntpointed; color a beautiful reddish yeIlow, mottled, covered with bloom, wine-colored when fully ripe; flesh greenish yellow, meaty, juicy, slightly subacid; pit small; cling; quality excellent. Recommended as one of the finest Plums for the Gulf Coast country.

Wild Plum. From some points where Excelsior and other hybrid Plums have been planted, we

have received reports of heavy blooming with no fruit-setting. This condition is probably brought about by lack of pollen from another tree. We have propagated a few Wild Plum trees which bloom with Excelsior, McRea, and Terrell. These wiIl serve as pollenizers and will probably overcome the difficulty.

\section{Excelsior Plum (See illustration, page 71)}

This PIum originated at the Glen Saint Mary Nurseries in 1887, and, first offered to the public in the winter of 1891-92, is today the most noteworthy PIum in the belt comprising northern Florida and the southern part of the Gulf States around into Texas. It originated from seed of the KeIsey Plum and was selected out of a number of KeIsey seedlings by our President, Mr. G. L. Taber.

Excelsior shows decided evidence of being crossed with some variety of the Chickasaw type, and is a well-marked hybrid. The tree is a remarkably rapid, vigorous grower, and is often so loaded with fruit that the branches must be propped to prevent breaking.

Fruit medium Iarge, $1 \frac{1}{2}$ inches in diameter, nearly round, no suture; color deep wine-red, with thick, bluish bloom and very numerous small dots; when fully ripe the fruit is almost purplish red; stem short; skin thin, tough, not bitter nor astringent; flesh firm, juicy, yellowish with reddish color near the pit; quality exceIlent, flavor subacid; pit smaII; cling. The earliest Plum to ripen in Floridaabout June 1 to 10. Very handsome, and a fine shipper. More fruit of this variety is grown throughout northern Florida than of all other varieties of Plums put together.

We do not hesitate to say that Excelsior, TerreII and McRea are the most satisfactory varieties for planting throughout the Iength and breadth of Florida, and throughout the GuIf Coast country westward to the Rio Grande. While adapted to this extreme range of latitude, we particularly recommend them for the extreme South.

\section{Mulberries}

The Mulberry is weIl adapted generally to Southern conditions, and no fruit tree is more valuable on the farm. Its wide-spreading branches afford splendid shade throughout summer, and it is without question the best shade tree for poultry-yards and hog-pastures. The fruit is readily eaten by poultry and pigs, and it is no mean source of food-supply for them.

PRICES ON MULBERRIES.-On Mulberry Stock.

$$
\begin{aligned}
& 2 \text { to } 3 \text { feet...... } \\
& 3 \text { to } 4 \text { feet.... } \\
& 4 \text { to } 6 \text { feet..... } \\
& 6 \text { feet and up. }
\end{aligned}
$$

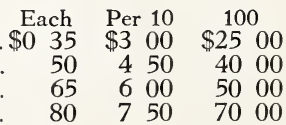

Hicks. Fruit sweet; tree grows rapidly and bears young; productive; should be grown by every farmer who keeps swine or poultry, this variety being of special value for this purpose; continues in bearing four months of the year, which makes it an exceptionally valuable variety.

Stubbs. Large, black; acid; excellent; prolific. Fruit from $1 \frac{1}{2}$ to 2 inches Iong, superior to any other. Tree vigorous and handsome.

Townsend. Berries of medium size and fair quality. Ripens very early; should be planted where birds are apt to ruin other early fruits. 


\section{SOUTHER PLANTINGFACTS}

THE PINEAPPLE PEAR, continued

eight to ten years old is not uncommon, and older trees have been reported as producing over 100 bushels per tree in a single season. The fruit is large and handsome, with a pleasing odor somewhat resembling that of the pineapple, and the flesh is coarse, crisp, and juicy, comparing favorably in quality with Kieffer. A prominent southern horticulturist writes: "Personally I like the quality a great deal better than I do the quality of the Kieffer, but considering it commercially, it would be sold in the same class with Kieffer." It cannot be classed as a dessert Pear, but for cooking or canning, or for any culinary use, it is a very valuable variety.

It is adapted to a wide range of soils and can be grown on dry sandy land or on soils that are too moist for most other fruits. The Pineapple Pear is very highly resistant to Pear blight, and we feel certain that Pear blight will never interfere with the growing of this variety in the South. The fruit ripens during July and August, and can be held on the trees for several weeks after it is ready to pick.

Kieffer. Fruit large to very large; yellow, with bright vermilion cheek, very handsome; flesh very juicy, brittle, a little coarse but of good quality. September and October.

Le Conte. Fruit Iarge to very Iarge, pyriform; skin smooth, pale yellow; quality good when properly handled. Season, July.

Prices on Pineapple, Kieffer, and Le Conte Pears on Japan Stocks. $\quad$ Each Per $10 \quad 100 \quad 1,000$ 2 to 3 feet......\$0 $35 \quad \$ 300 \quad \$ 2500 \quad \$ 20000$ 3 to 4 feet......... $50 \quad 4 \quad 50 \quad 4000 \quad 30000$

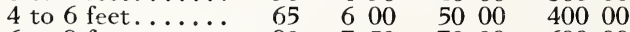
6 to 8 feet......... $80 \quad 750 \quad 7000 \quad 60000$

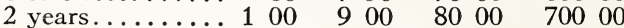

\section{JAPAN PERSIMMONS}

Since its successful introduction into this country in 1875, the Japan Persimmon (Diospyros Kaki) has been slowly but steadily gaining in favor. Since native Persimmon seedlings (Diospyros Virginiana) are used as stocks on which to grow the Japan sorts, they can be grown on as wide a range of soil as the native Persimmon, and it is not too much to say that they will succeed with the minimum of care and attention with which any fruit may be successfully grown. At the same time, they respond generously to good care and cultivation. The trees are vigorous, prolific and have few enemies. Some varieties are weakened because of their habit of overbearing, and their crops should be thinned. The regions in which the Japan Persimmon may be grown cover the cotton-growing belt. As the fruit keeps and ships weII, it can be placed on the market in good condition, though it requires some experience to know just when the different varieties are in best shipping condition. Wherever known in the markets, it meets with ready sale.

A carefully selected list of varieties will give fruit in abundance from August to December and Iater. During a very considerable portion of this period other fruit crops are out of season.

\section{Planting and Management}

The soil on which the Persimmon orchard is set should be weIl prepared. Old field land may be used, but, if in poor condition, it should be built up before setting the trees. This can best be done by growing a crop of cowpeas or velvet beans on the land and plowing them under previous to planting.

While Persimmon trees can be set out at any time

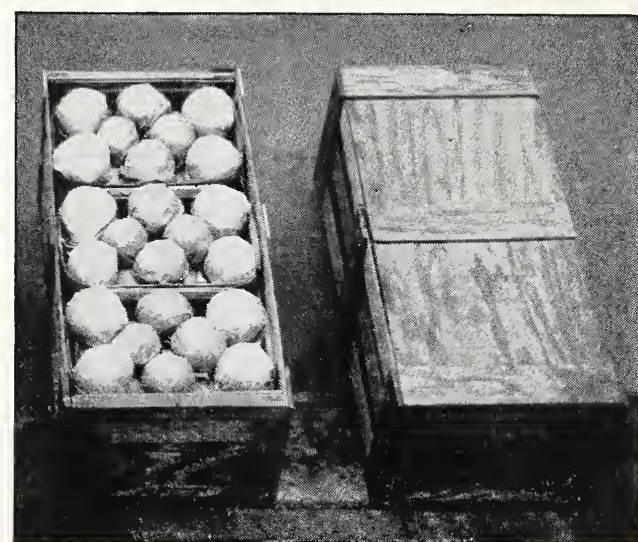

Persimmons Packed for Shipment 


\section{PERSIMMONS, continued}

between November 15 and March 1, in the Lower South, preference in planting should be given to the period from December 1 to February 1. They should be given a distance of 18 or 20 feet apart each way, 134 or 108 trees per acre. Great care should be exercised in setting them, and the roots should not be allowed to become dried out. The tops should be cut back to 2 or $2 \frac{1}{2}$ feet on the smaller sizes.

Cultivation during the early portion of the season should be frequent and thorough. This may be discontinued about July 1 or 15 , and a cover crop of natural weeds or cowpeas or beggarweed should be allowed to cover the ground. To avoid danger from fire during winter, this should be turned ints the soil after it has become dead and dry in autumn. Commercial fertilizers can be used to advantage.

\section{Marketing Japanese Persimmons}

The fruit should be gathered when fully grown but before the softening process begins, if it is intended for long-distance shipment. It should be cut from the trees and handled very carefully to prevent bruising. It is usually best, even when the fruit is intended for home use, to gather it before it begins to soften, and ripen it in a dry, warm room. The flavor is quite as good as when ripened on the trees.

Immediately after picking, the fruit may be packed for shipment. The best crate is the six-basket carrier commonly used for peaches. Small specimens should be discarded and the fruit should be carefully graded for size. Wrap the fruits in a good quality of fruit wrapping paper, and arrange them in baskets in regular order according to size. If the fruit is sent into a new market a card giving the name of fruit, stating the degree of maturity at which it is best, and giving directions on how to use it, should be placed in each crate, or better still, in each basket.

\section{Cause and Cure of Dropping}

In 1909 we discovered the cause of the dropping of partly developed Persimmon fruit and how to stop it. The pistillate flowers of the Japanese Persimmon contain no pollen and the dropping of the fruit is due to Iack of pollenation. Shortly after we found this out, a variety which produces staminate or pollen-bearing flowers in great abundance was located. Since then experiments have proved that when a staminate variety is planted in close proximity to pistillate varieties of Japanese Persimmons, the flowers are poIlenated: fruit forms and grows on to maturity. In 1915 we introduced this staminate variety under the name Gailey, after having found definitely that its pollen, carried by bees and

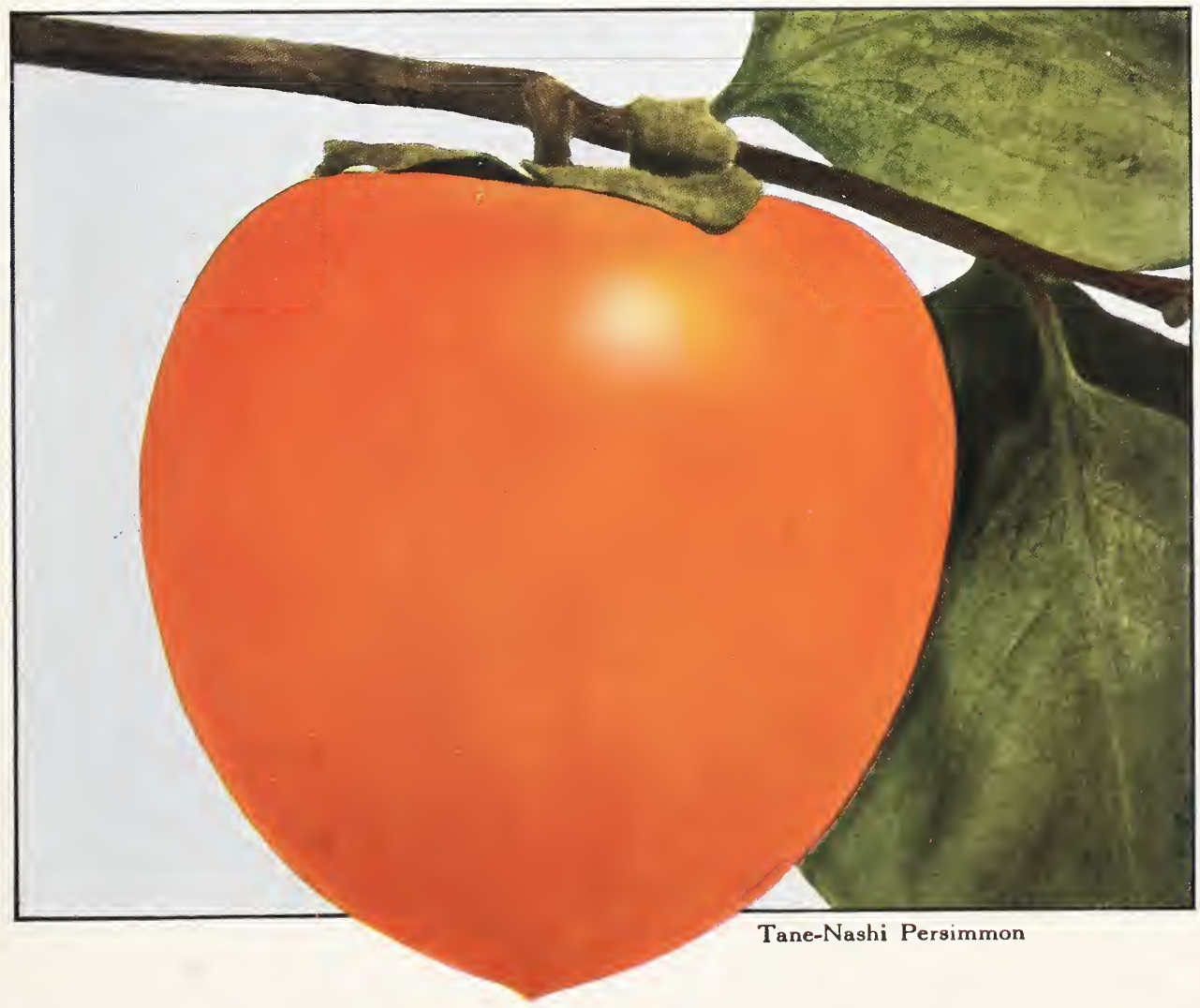




\section{PERSIMMONS, continued}

insects, would cause good crops of fruit to set. A few trees of this variety, at least one in ten, should be planted in every orchard. The pollen from native American Persimmon trees will not help. PRICES ON PERSIMMONS.

$$
\begin{aligned}
& 2 \text { to } 3 \text { feet. } \\
& 3 \text { to } 4 \text { feet. } \\
& 4 \text { to } 5 \text { feet. } \\
& 5 \text { to } 7 \text { feet. } \\
& 2 \text { years. . } \\
& 3 \text { years... }
\end{aligned}
$$

Gailey. SmaII, oblate-conical, apex rounded, with small sharp point often marked with circular Iines; color dull red, surface pebbled; flesh dark about the seeds, meaty, firm, juicy; seeds flat, oval, rather long. This variety is noteworthy for the production of staminate flowers for the pollenation of the pistillate flowers of other varieties. Recommended for its flowers.

Hachiya. Very Iarge, oblong, conical, with short point; very showy; diameter $3 \frac{3}{4}$ inches Iongitudinally and $31 / 2$ inches transversely; skin bright dark red, with occasional dark spots or blotches and rings at the apex; flesh deep yellow, with seed. Astringent until ripe, then very fine. The largest and handsomest of all. Tree vigorous.

Hyakume. Large to very large, varying from roundish oblong to roundish oblate, but always somewhat flattened at both ends; generally slightly depressed at the point opposite the stem; diameter $23 / 8$ inches longitudinally and $31 / 8$ inches transversely; skin light buff-yeIlow, nearly always marked with rings and veins at the apex; flesh dark brown, sweet, crisp and meaty, not astringent; good while still hard. A free bearer.

Okame. Large, roundish oblate, with weIldefined quarter marks, point not depressed; diameter $23 / 8$ inches Iongitudinally and $31 / 8$ inches transversely; skin orange-yellow, changing to brilliant carmine, with delicate bloom and waxy, translucent appearance; light clear flesh when ripe, with light brown center around the seeds, of which it has several; loses its astringency as soon as it begins to ripen; quality fine.

Ormond. Small to medium, $25 / 8$ by $17 / 8$ inches, conical, smooth; color deep bright red with thin

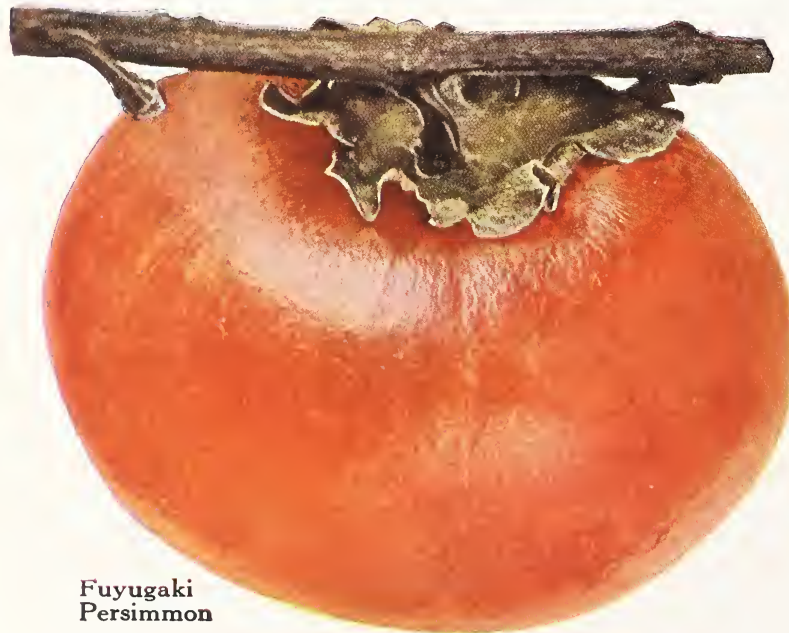

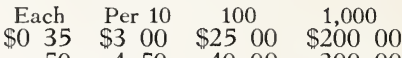

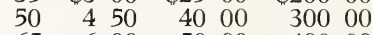

$\begin{array}{lllllll}65 & 6 & 00 & 50 & 00 & 400 & 00\end{array}$

$\begin{array}{lllllll}80 & 7 & 50 & 70 & 00 & 600 & 00\end{array}$

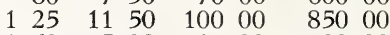

$\begin{array}{llllllll}1 & 60 & 15 & 00 & 125 & 00 & 1000 & 00\end{array}$

bloom; skin thin, tough; flesh orange-red, meaty or jelly-like when fully ripe; seeds large, Iong, pointed. Quality very good. Ripens late (December) and may be kept for a long time after being gathered.

Taber's No. 23. Medium oblate, flat or depressed point; $11 / 8$ inches by $23 / 8$ inches; skin rather dark red, with peculiar stipple marks; flesh dark brown, sweet and free from astringency; seeds; good. Prolific, and one of the best of the dark-fleshed sorts.

Tamopan. Fruit Iarge to very large, specimens often weighing one pound each; flattened, oddly marked by constriction about the middle; color golden red; fruit astringent until fully ripe; quality very fine; it makes a large tree.

Tane-Nashi. Large to very large, roundish, conical, pointed, very smooth and symmetrical; diameter $31 / 4$ inches longitudinally and $33 / 8$ inches transversely; skin light yellow, changing to bright red; flesh yellow and seedless; quality very fine; perhaps the most highly esteemed of the lightfleshed kinds. Vigorous; prolific. Uniform size, quality and shape combine to make this the most desirable market variety.

Triumph. Medium, tomato-shaped; skin red; flesh yellow; generally has a few seeds; very productive; quality best. Ripens from September to December. Excellent for home use or for market.

Tsuru. Large, slender, pointed; longest of aII in proportion to its size; skin bright red; flesh orangeyellow, astringent until fully ripe. Very late.

\section{Fuyugaki Persimmon}

In connection with our Persimmon investigations which led up to the discovery of why the trees dropped their fruit, and the introduction of staminate Persimmon varieties, we introduced and have tested a very large number of varieties from different parts of the world. Among these Persimmons was one sent us by the section of Seed and Plant Introduction, U. S. Department of Agriculture, Washington, D. C., in 1913, under the name Fuyugaki. This variety possesses several characteristics which place it in a class by itself. It is never astringent, it is always light-fleshed, it is edible while still hard, and may be eaten like an apple. It keeps weII, and in quality it is one of the very best. The fruit is of medium size, rather flattened, beautiful deep red in color, and the tree is very prolific. It can be placed on the market hard, and can be eaten without waiting for the fruit to soften. 


\section{Glen Saint Dary Nurseries Co. Glen Saint Mary, Florida}

\section{FIGS}

No fruit is more valuable in the southern fruitgarden than Figs. They can be closely planted10 to 12 feet apart-and yield heavily. The Figcanning industry is gradually extending throughout the South, and since several tons of fruit can be produced on an acre of ground, it is well adapted to intensive culture. The preserved product put up at the present time in no wise supplies the demand, and we look for a very material increase in the Fig-canning industry.

The fresh Fig is also finding its way into the markets, and meeting with a ready sale. Carefully picked at the right stage of maturity and packed in strawberry crates, they can be placed by express in distant markets, four or five hundred miles, or even more, in good condition.

Figs come into bearing very early, and for that reason commend themselves to the fruit-grower. With a proper selection of varieties, fruit may be secured from June to November. Figs often succeed best when planted so the roots may run beneath buildings. Orchard plantings should be made on heavy soils, clay soils, or on lands where the clay is very close to the surface.

Figs succeed best with little or no cultivation and such cultivation as is given should be very shallow because the roots are close to the surface. MuIching gives satisfactory results because it keeps the roots cool and moist.

\section{PRICES ON FIGS.}

$$
\begin{aligned}
& 2 \text { to } 3 \text { feet. . } \\
& 3 \text { to } 4 \text { feet. } \\
& 4 \text { to } 5 \text { feet. }
\end{aligned}
$$$$
5 \text { to } 7 \text { feet. . . }
$$

Brunswick. Fruit very Iarge, broadly pearshaped, with short, rather slender stalk; ribs weII marked, eye large, open, with rosy scales; skin tough, dark brown in color; pulp thick, soft, quality very good. Satisfactory variety.

Brown Turkey. Size medium to large; broadly pear-shaped, with short, thick stalks; ribs few in number; color coppery brown; flesh white, or slightly amber-colored, shading to pink about the seeds; flesh solid, excellent quality. This variety ranks with Celeste in hardiness. It is very hardy and desirable.

Celeste. SmaII to medium, pear-shaped, ribbed; violet-colored, sometimes shading to purplish brown, covered with bloom about half

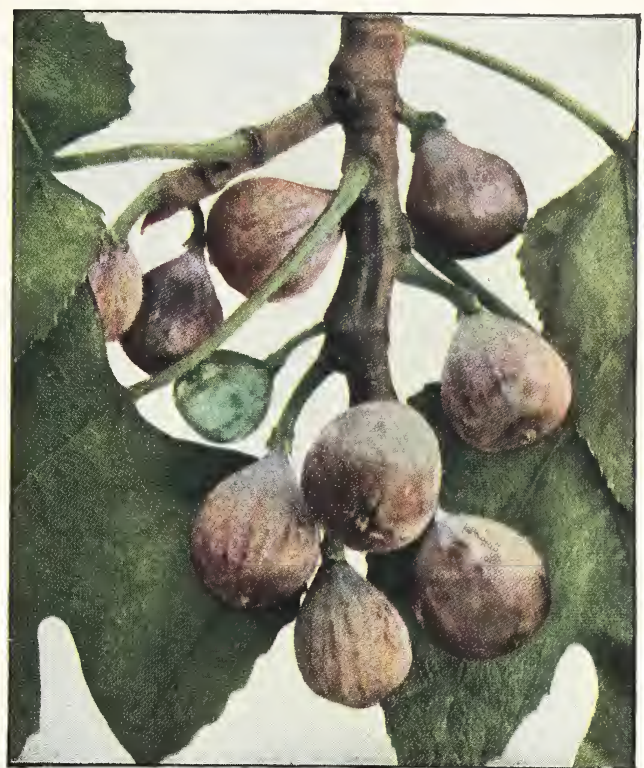

Celeste Figs $\begin{array}{ccc}\text { Each } & \text { Per } 10 & 100\end{array}$

$\begin{array}{rrrrr}50 & 4 & 50 & \$ 25 & 00 \\ 6 & 4 & 00 & 50 & 00\end{array}$

$80750 \quad 7000$

way up from the neck; stem short, stout. Flesh whitish, shading to rose-color at center; flesh firm, juicy, sweet, excellent quality. One of the hardiest varieties of Figs, and can be grown far outside of the usual limits of culture; very desirable for canning and preserving.

Green Ischia. Fruit of medium size, long; pulp rosy red, soft, melting, quality rich, sweet. A variety of very high quality. The tree is a strong grower.

Lemon. Fruit medium to Iarge, flattened, faintly ribbed, light yellowish green; stem short, stout; flesh white, sweet, rather soft, quality fair to good; season July. Very vigorous and prolific.
$65 \quad 600 \quad 5000$

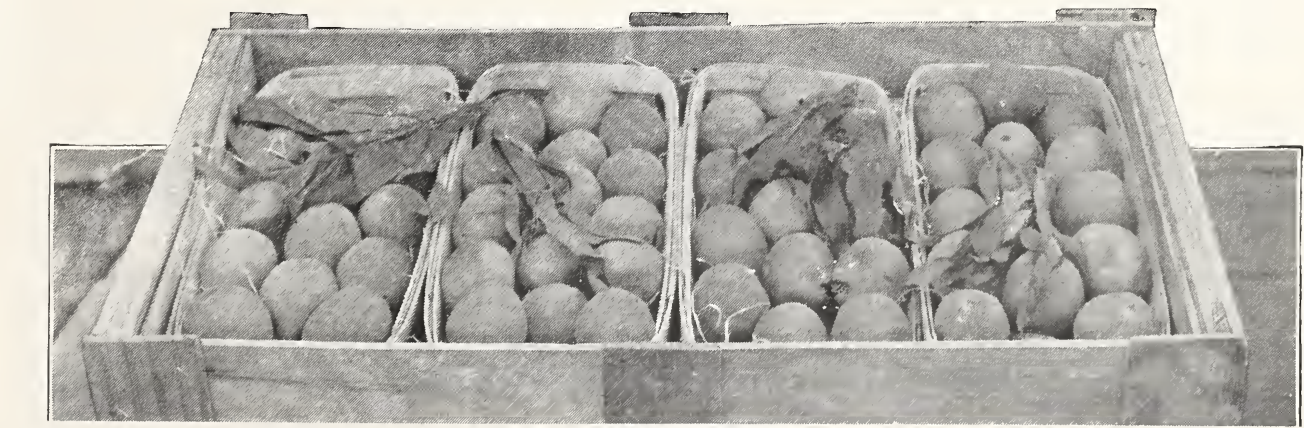

A crate of Figs 


\section{SOUTHERN PLANTING FACTS}

\section{POMEGRANATES}

The Pomegranates are very hardy shrubs which can be grown throughout the Gulf States and the coastal sections of Georgia and the Carolinas. The brilliant scarlet flowers are produced in profusion, and an abundance of fruit usually follows. The fruit, which is used in making jellies, marmalades and acid drinks, has a fresh crispness, and a delicate, sprightly flavor found in few fruits. As a commercial fruit, the Pomegranate is steadily gaining in favor. It does best on rather dry, well-drained soils.

PRICES ON POMEGRANATES.-On Own Roots.

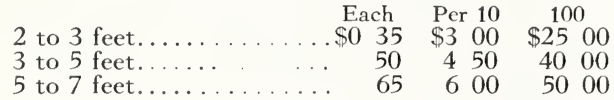

Purple-seeded. Large; rind thin; juice cells surrounding the seeds dark ruby or wine-color; sprightly, vinous and of the best quality. A very choice variety and one of the best for general culture. It is being more largely planted.

Rhoda. Brought to our attention by one of our employees who had been growing it for years. The fruit is of large size; rind thin but tough; juice-cells large and of beautiful wine-color; crisp, sweet and of exquisite flavor.

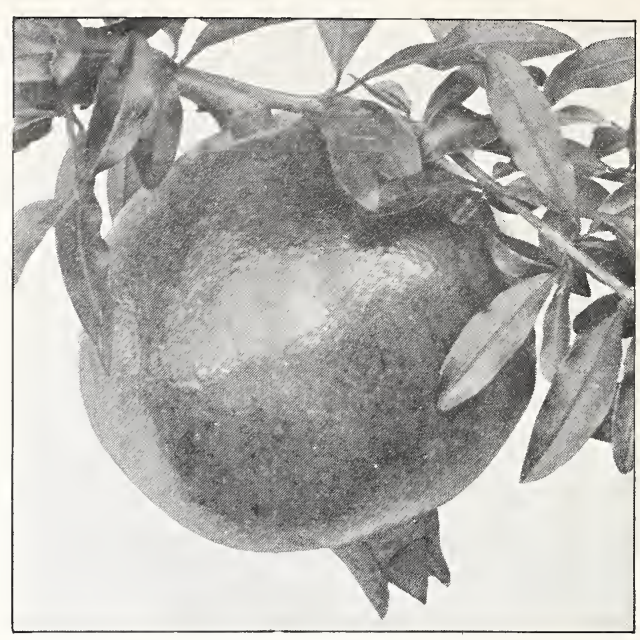

Rhoda Pomegranate

Sweet. This variety has large, sweet fruit and is one of the best of the sweet group; handsome.

Wonderful. A new, fine, Iate-ripening sort, with Iarge, highly colored fruit and beautiful pulp. Handsome and desirable.

\section{LOQUAT (Eriobotrya japonica)}

The Loquat is a strikingly handsome, Iarge-leaved evergreen tree adapted to the GuIf-Coast country and more tropical locations. Desirable as an ornamental.

The fruit is about the size of a Wild Goose plum, oblong, bright yellow, subacid, has an agreeable flavor. Highly prized for cooking.

The white blossoms, borne in spikes, come during the winter months; consequently, while trees are quite hardy aII along the Gulf Coast, fruit can be counted on only in sections comparatively exempt from severe cold.

PRICES ON LOQUATS.-From Seed.

2 to 3 feet...

Each Per 10

3 to 4 feet...

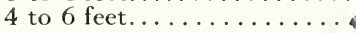

$50 \quad 400$

\section{GUAVAS}

The Red Cattley and Yellow Chinese may be grown in north Florida as well as in more tropical sections. Excellent for use as dessert fruits or for making preserves and jellies.

Red Cattley. A handsome evergreen shrub with glossy green leaves, producing large quantities of smaIl red fruits, 1 to $1 \frac{1}{4}$ inches in diameter. It grows in northern Florida. Seedlings only.

Yellow Chinese. Almost identical with the Red Cattley, except that the fruit is yellow instead of being red-fleshed. Grown from seed.

PRICES ON GUAVAS.

4-inch pots. .

6-inch pots. .

Each Per 10

$\begin{array}{lll}\text { Ea } & 50 & \$ 4 \quad 50\end{array}$

75650

\section{BANANAS}

The Banana is a rapid-growing plant of great value for its fruit and for decorative purposes. It requires rather moist ground and plenty of plant-food for best results. Both stable manure and commercial fertilizer may be used. The plants may be set on the shores of lakes or the banks of streams.

Cavendish. A rather tender, dwarf variety, producing an excellent quality of fruit.

Hart (Hart's Choice, or Lady-Finger). A valuable hardy sort; fruit of fine quality.

Orinoco (Horse Banana). A very hardy strong-growing variety, adapted to northern Florida and the Gulf Coast. Bunches smaII. 


\section{Glen Saint Dary Nurseries Co. Glen Saint Mary, Florida}

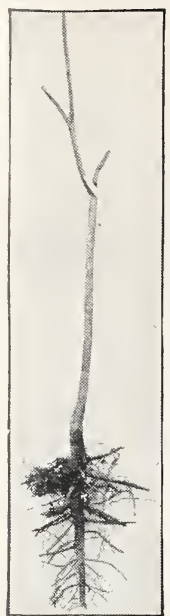

Bare-rooted

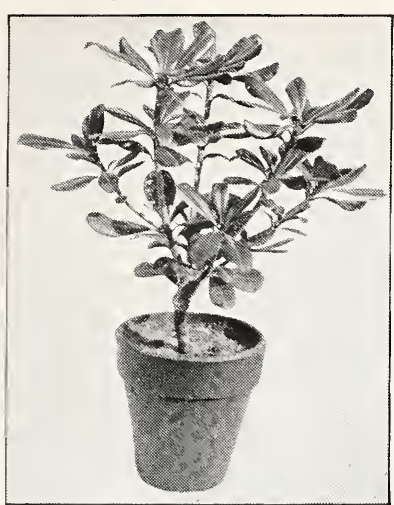

Pot-grown

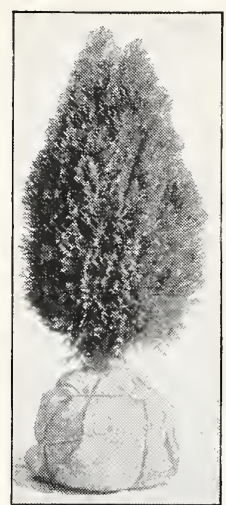

Spade-lifted

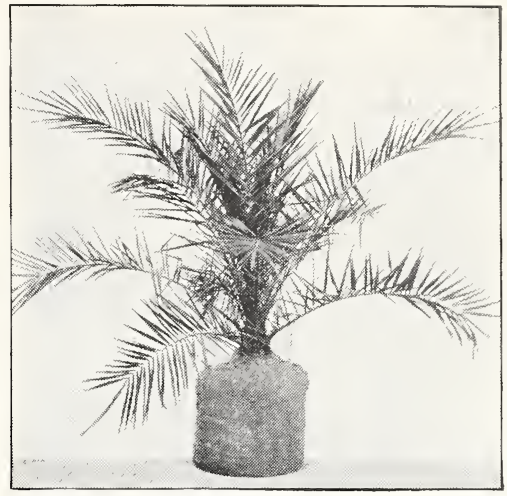

Machine-balled

\section{Handling Trees and Other Plants}

$\mathrm{N}$

URSERY trees and other plants are grown in two different ways-in the open ground or in pots, tubs, and boxes. Those grown in pots or tubs are easily handled; if grown in the open ground, they are taken up either bare-rooted or with earth about the roots. When dug with earth about their roots, they are either spade-lifted or machine-balled. Hence, there are really four ways of handling them for transplanting.

Pot-grown Plants. Many different kinds of plants are grown in pots, tubs, or boxes. They may be shipped and transplanted at any time of year and immediate planting effects secured. Usually the pot or tub is removed before shipment and the earth about the roots is wrapped in paper or burlap.

Bare-rooted Plants. Plants taken from the open ground with bare roots are usually handled only during the winter dormant season, from November to April. All deciduous trees, as peach, pear, plum, mulberry, dogwood, red-bud, sweet gum, and many more, are examples. Orchards or groves are always planted with bare-rooted trees.

Spade-lifted Specimens. If the roots of shrubs or trees are very numerous, fine, and fibrous they hold earth well. They can be dug with the roots in place in the original soil. Burlap is then tied about the baIl of earth and these are known as spadelifted, balled and burlapped plants. They must be carefully handled so as not to separate the roots from the soil.

Machine-balled Specimens. These are dug with a special machine which leaves the plant in a cylinder of soil. This cylindrical ball is covered with burlap tightly sewed about it. They, too, must be carefully handled and lifted by the earth-baII and not by taking hold of the branches, stems, or trunk. The burlap should not be removed when the plants are set out. (Very large specimens may be handled in this way.)

For spade-lifted and machine-balled plants an extra charge is made.

\section{Planting}

The Iand on which trees are to be set should be thoroughly prepared before planting. Too frequently this important matter is neglected or pourly done, but it pays to give particular attention to this part of the work. It is easier to put the land in good condition before planting than after, and, if the trees are to bring the results desired, it must be done at some time. It is best to clear the land a year in advance of planting, then grow a crop of cowpeas or velvet beans and turn it back into the soil. Good results may be secured without this, but it is a good plan to follow whenever possible.

Staking. After the land has been well plowed, harrowed and leveled, a 3 or 4 -foot stake should be set where each tree is to stand. Laths make good stakes for this purpose. While a number of different plans may be used in spacing the trees, it is usually best to set them in squares or in rectangles.

Planting Distances. The distance apart at which the trees should be set depends upon the character of the soil, the moisture it contains, the kind of trees and the ideas of the planter. Usually they should be given a goodly distance. A table of usual planting distances is given on the inside back cover page.

Care of Trees on Arrival. When the trees arrive, if everything is in readiness, they may be taken directly to the freld and set out, taking the trees from the boxes as needed. If the number is large, or there is a delay of more than a few days, it is best to open up the boxes or bales and heel-in the trees. This is done by digging a trench deep enough to accommodate the roots nicely, straight down on one side, sloping out to the ground-level on the other. In this trench place the roots, the tops in slanting position, cover with earth, packing well among the roots, use some water, and cover the tops with packing material, straw or grass, to shade them. From this heeling-in place they may be taken for planting, and carefully protected from the sun with damp burlap until placed in the holes.

Digging Holes-Fertilizers. It is best to dig the holes just in advance of planting to prevent drying or baking; also loss of moisture. The holes should be made 6 inches wider and deeper than nccessary to accommodate the roots. Place the topsoil in a pile by itsclf when the holes are dug. Commercial fertilizer analyzing about 6 per cent phosphoric acid, 4 per cent ammonia, 3 per cent potash, may be used at the ratc of one-half to one pound per tree, thoroughly mixed with the topsoil in filling in around 
the roots. We do not recommend the use of stable manure in the holes at time of planting.

Pruning. Some kinds of nursery trees must be pruned before shipping. Others are not pruned. It is a safe rule with practically all plants that the tops and broken roots should be cut back before planting. For years it has been a part of our nursery practice to prune nearly all stock lifted from the open ground before shipping.

Setting the Trees. Set the trees the same depth they stood in the nursery rows. The exact point can be determined by the earth-marks on the "collar." Citrus trees, particularly, are very much injured by too deep planting, and it is a safe rule with all trees and shrubs to set them a little higher than they grew rather than lower. Spread out the roots carefully by hand, and pack the earth weIl around them.
When the hole is three-quarters filled up, pack thoroughly with the feet. This is important. More trees are lost from loose packing than from any other cause. After packing thoroughly, and before the hole is quite filled up, pour in water, especially if the soil is dry. As the water sinks down into the earth, it helps to pack the soil in all the small corners among the roots. When the water has sunk away, fill up the balance of the hole, pack again with the feet, straighten up the tree and level off. If the weather and soil are dry it is often an excellent plan to bank up around the tree with dry soil. This prevents evaporation of moisture from the tree, keeps it steady in the ground, and is a great protection. This bank can be removed after it has served its purpose. Banking is a good protection against frost.

\section{General Care}

After carefully planting trees or shrubs they should receive such care and attention as will keep them in thrifty growing condition, and, if the best results are desired, they should never be allowed to become stunted in their growth. To bring about this condition they must be cultivated frequently, fertilized from time to time, and kept free from insects and diseases. Only those who give their trees the care they require can hope to secure the maximum results from their plantings. Consult your successful neighbors and be guided by their experience under similar conditions.

Cultivation. The ground around newly set plants must be kept free from weeds, because a growth of weeds deprives the trees of needed moisture and plant-food. Lawn specimens may be cared for by simply cutting out the turf in a circle of 2 feet radius around the trees, and keeping the circles well cultivated. Young orchard trees may be handled by cultivating a narrow strip 3 to 5 feet wide on each side of the tree-rows and the remainder of the ground (not cultivated) should be planted with a cover-crop to shade the soil and improve its condition when it is plowed under. It is best to continue the cultivation of the narrow strip throughout the season, or well up into autumn. Of course, if heavy rains occur, cultivation of young trees may at times be omitted, but even then weeds must not be allowed to grow up around the trees, thereby shading them to an injurious degree.

The cultivation of older trees differs in some particulars from that given young trees. In the first place cultivation should begin in spring some time before the trees start into growth and should be continued at intervals of ten days or two weeks throughout the spring months up until about June 15 or July 1. A cover-crop should then be given possession of the ground until autumn. The best cover-crops in the Lower South are beggarweed, cowpeas and velvet beans. In spring, the whole surface of the ground should be cultivated, and if the weather is dry, cultivation should be given more frequently.

The most important objects of cultivation are to preserve a dust mulch and conserve moisture. The best cultivation tools are a disc harrow, an extension disc, an Acme harrow and, for heavy lands, a spring-tooth harrow. The plow is not required, except when the cover-crop is turned under.

Fertilizers. The fertilizer already recommended for use at time of planting will be found about right for young trees and, under most conditions, its use may be continued until the trees are well grown and commence to bear. On shade trees and shrubs its use may be continued throughout. When fruit trees begin to bear, the composition of the fertilizer applied should be changed. The amount of potash should be increased. In general, it will be found that a fertilizer containing 3 per cent ammonia, 6 per

cent phosphoric acid, and an increased amount of potash will be about right. The composition of the fertilizer should be varied to meet special conditions.

The general tendency in the use of commercial fertilizers is to make frequent applications of smaIl amounts. In arriving at the quantities required on shade trees, it is a good plan to use from one to two pounds for each inch in diameter.

If a young orange tree received one-half pound at time of planting in January, it should receive a pound in March, another in June, and another in September. In its second year, it should be fertilized in February, June and September, giving about one pound and a half at each application. After the second year, there should be a gradual increase as the trees become older; those who secure best results fertilize liberally.

In fertilizing young trees, the fertilizer should be scattered in a band 2 feet wide, beginning back 6 inches from the trunk. As they become older, the fertilizer should be spread out toward the ends of the branches, and in old orchards or groves it should be broadcast over the whole surface as the roots make their way into all parts of the soil. After applying fertilizer the ground should be cultivated to a depth of three or four inches.

Insects and Diseases. These must be watched for and guarded against. Dead branches should be removed from the tops of trees and burned. They often contain spores of diseases or have become the breeding-places of noxious insects. In some localities many insects may be controlled effectively through the agency of friendly fungi; in others it is necessary to spray as well. In a general way it will be found that bordeaux mixture is effective against fungi, lime-sulphur wash as a winter spray against scale insects and fungi on deciduous trees, rust mite, purple mite and red spider on citrus; arsenate of lead against biting or chewing insects, and whale-oil soap or miscible oil against sucking insects such as white fly and against various scale insects. The best time to spray for scale insects is just after the eggs have hatched in spring and the young are moving about. White-fly can be controlled by spraying in winter, being particular to cover the under sides of the leaves where the insects are at rest. 
IMPORTANT: Before making out your order, please read "Terms of Business" on inside front cover page of catalogue. Our business is conducted according to these terms, and misunderstandings or possible dissatisfaction can be avoided by your careful attention to them

GLEN SAINT MARY NURSERIES CO. Date

\section{Glen Saint Mary, Florida}

For amount enclosed, $\$$ send me by (Write here "Freight," "Express," "Parcel Post," or "Use your discretion." the Trees and Plants designated below:

WRITE PLAINLY. Ladies please give title Miss or Mrs.

Name

Street or Box No.

P. O. Address

State

Shipping Address

Date you wish shipment made

SIZE

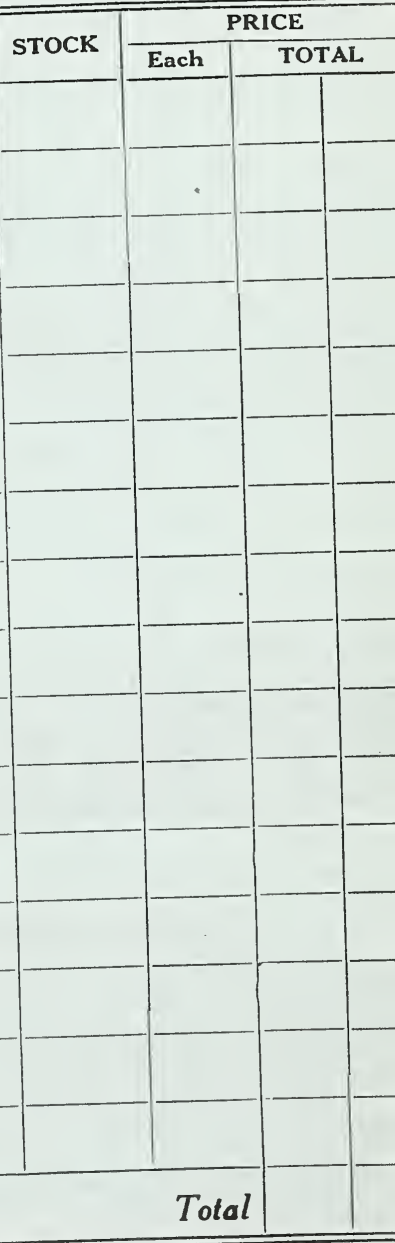

If you wish us to substitute in case varieties are ex hausted, write here the word "Yes" 


\begin{tabular}{|c|c|c|c|c|c|}
\hline \multirow{3}{*}{ QUANTITY } & \multirow{3}{*}{$\begin{array}{l}\text { FULL NAME OF VARIETY } \\
\text { (If Citrus Trees, specify on what stock wanted) }\end{array}$} & \multirow{3}{*}{$\frac{\text { SIZE }}{A \text { mount }}$} & \multirow{3}{*}{$\begin{array}{l}\text { STOCK } \\
\text { brought }\end{array}$} & \multicolumn{2}{|c|}{ PRICE } \\
\hline & & & & \multirow{2}{*}{$\begin{array}{l}\text { Each } \\
\text { forward }\end{array}$} & Total \\
\hline & & & & & \\
\hline t & $\cdot$ & & & & \\
\hline & & & & & \\
\hline & & & & & \\
\hline & & & & & \\
\hline & & & & & \\
\hline & & & & & \\
\hline & & & & & \\
\hline & & & & & \\
\hline & . & & & & \\
\hline & & & & & \\
\hline & & & & & \\
\hline & & & & & \\
\hline & & & & & \\
\hline & & & & & \\
\hline & & & Total & Imount & \\
\hline
\end{tabular}

\section{SPECIAL ORDER SPACE FOR TEMPLE ORANGE TREES}

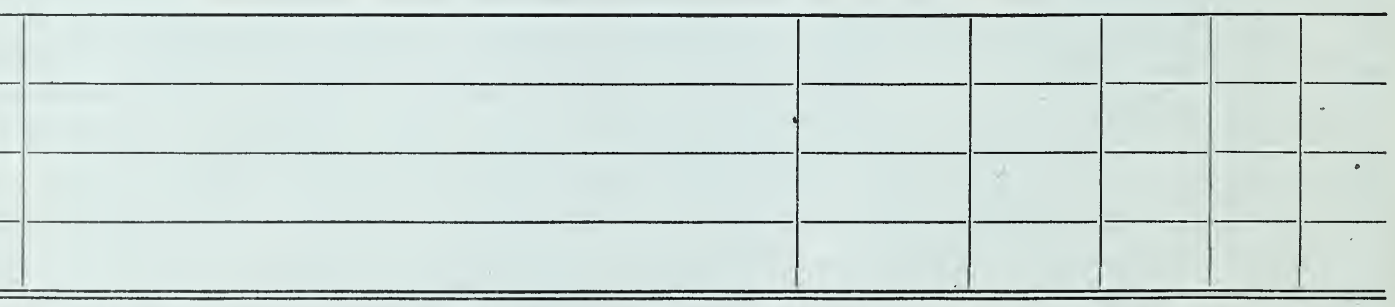

To protect myself and other purchasers of Temple Orange Trees against the competition of inferior fruit sold under the same name, and to protect you in the right to exclusively propagate and distribute this orange, and in consideration of the fact that you are to supply me the trees ordered above, I agree not to sell or give away, or to permit anyone else to take any scions, buds, or cuttings from these trees, or from their progeny, for a period of twenty-five years.

I further agree not to sell or give any of these trees away, and in case of disposition of property on which the trees are planted, I obligate myself to make this agreement $a$ condition of the transfer.

Signed

\section{Explanation of the Order Sheet and Protection Agreement Printed Above}

You will note in the order blank herewith a clause binding you not to dispose of any budwood of the trees of the Temple orange or of the trees themselves.

This agreement is both for your protection and for ours. We regard it of just as much importance, if not more, from your standpoint as from ours, and believe you will agree with us.

If the propagation and distribution of trees of this orange are not confined to a single responsible, dependable channel, all sorts and kinds of so-called Temple oranges will be offered within a few seasons.

The fruit of some of these strains, if indeed not all of it, except the original from our nurseries, will be inferior, and when this poorer fruit is marketed under the Temple name it will have a tendency to lower the prices offered for true Temple oranges.

By the restrictions we are placing on the sale of Temple budwood and trees, we are endeavoring, just as far as possible, to protect our customers against this condition. You know that the fruit of the true Parson Brown or Pineapple orange, for instance, does not sell as well as it would if there were none of the false strains in the market.

This Agreement providing against the sale of budwood also is for our protection against unfair competition. We have thoroughly tested out this fruit and are propagating trees under conditions which assure you that they are healthy, true to name and first class in every way. It is but common fairness and simple justice that all selling rights in the Temple orange should be our property. 


\section{LARGE-SIZED TREES AND SHRUBS FOR IMMEDIATE RESULTS}

In the foregoing pages of our Catalogue we have listed the regular sizes of trees and plants. Very frequently our customers are interested in large-sized specimens with which to secure quickcr effects from their plantings. We are able to furnish these in a number of different sizes and varieties, and we are prepared to move them with large balls of earth about the roots. We shall be pleased to furnish descriptions and prices upon request, stating size and kind desired.

\section{PROPER DISTANCES FOR PLANTING}

Oranges on common stocks...25 to $30 \mathrm{ft}$. each way Oranges on C. trifoliata.....18 to $20 \mathrm{ft}$. each way Kumquats.............. 10 to $12 \mathrm{ft}$. each way Peaches and Apples...........18 to $20 \mathrm{ft}$. each way Plums.................... to $18 \mathrm{ft}$. each way Japan Persimmons..........15 to $20 \mathrm{ft}$. each way
Pears, Pineapple..........25 to $35 \mathrm{ft}$. each way Pears, General varieties ...... . 20 to $25 \mathrm{ft}$. each way Grapes, Bunch varieties.......8 to $10 \mathrm{ft}$. each way Grapes, Muscadine type......18 to $25 \mathrm{ft}$. each way Figs .................. 12 to $15 \mathrm{ft}$. each way Pecans................40 to $50 \mathrm{ft}$. each way

\section{NUMBER OF TREES OR PLANTS TO THE ACRE}

\begin{tabular}{|c|c|c|c|c|}
\hline $\begin{array}{l}\text { Distance } \\
\text { apart, feet }\end{array}$ & $\begin{array}{l}\text { No. } \\
\text { of trees }\end{array}$ & $\begin{array}{l}\text { Distance } \\
\text { apart, feet }\end{array}$ & $\begin{array}{l}\text { Distance } \\
\text { apart, feèt }\end{array}$ & $\begin{array}{l}\text { Distance } \\
\text { apart, feet }\end{array}$ \\
\hline 8 by 8 & . .6880 & 13 by 13. & 18 by 18. & 30 by 30. \\
\hline 9 by 9 & .537 & 14 by 14. . & 19 by 19. . & 35 by 35 . \\
\hline 10 by 10 & 435 & 15 by 15. & 20 by 20. & 40 by 40. \\
\hline 11 by 11 & .360 & 16 by 16. & 22 by 22 & 45 by 45 . \\
\hline 12 by 1 & .302 & 17 by $17 \ldots \ldots$. & 25 by $25 \ldots \ldots \ldots 69$ & 50 by 50 \\
\hline
\end{tabular}

\section{CONTENTS}

Terms of Business. . . . . . . .

Azaleas...............................

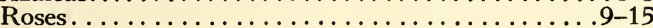

Palms and Cycads......................

Coniferous Evergreens..................20

Shrubs and Hedge Plants...............24-33

Shade Trees......................... 34-37

Bamboos. .

$34-37$

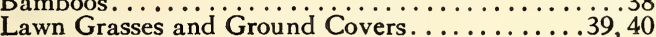

Vines.................... $41-43$

Bulbs and Related Plants.................43,44

Planting the Home Grounds. . ............45-47

New and Unusual Plants ...................., 49

Citrus Fruits..........................

Nut Trees........................65,66

Deciduous Fruits .................67-78

Handling Trees and Other Plants............. 80

\section{INDEX}

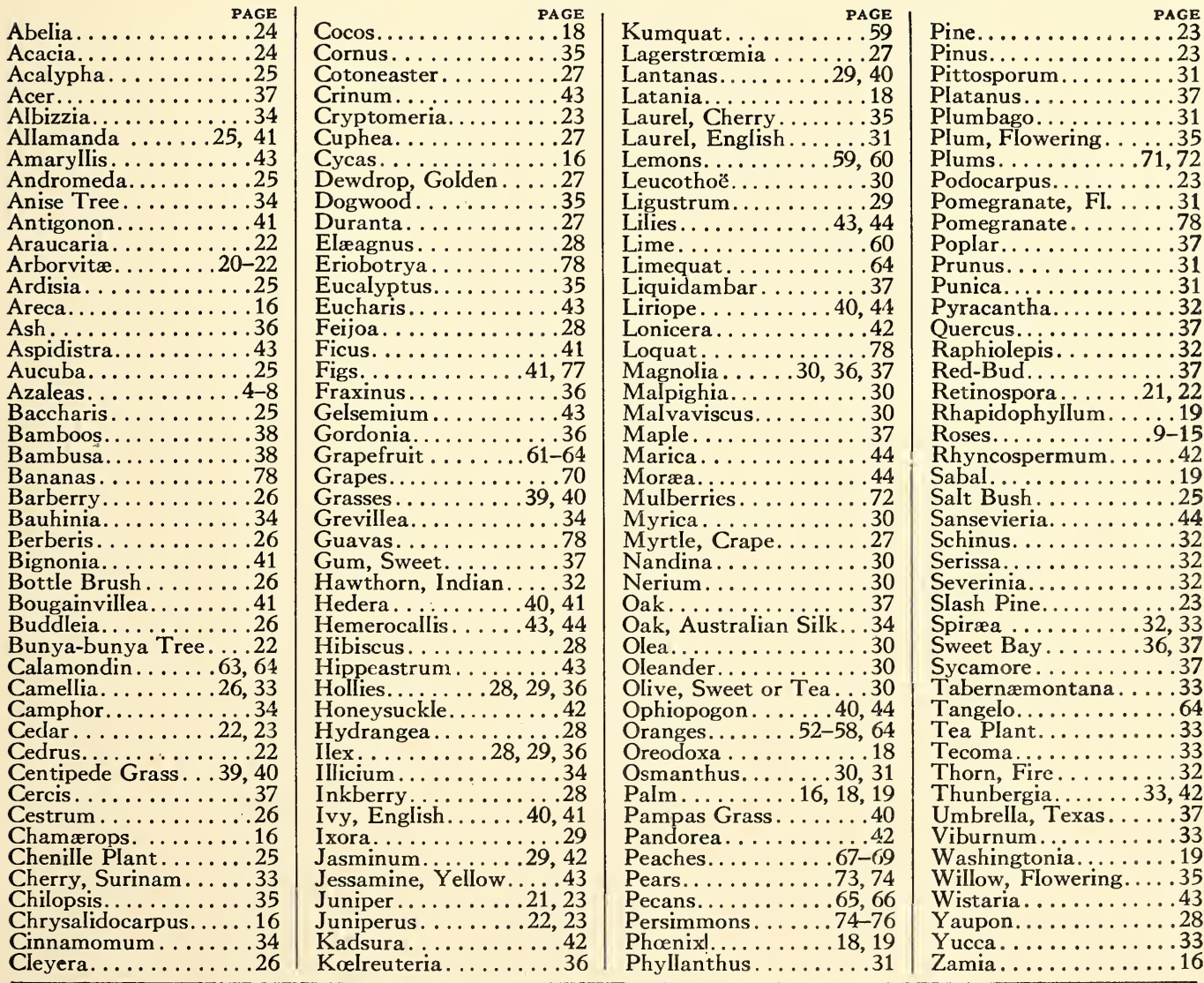


Glen SAInt Mary Nurseries Co.

GLEN SAINT MARY, FLORIDA 